\title{
De organisatie van de verpleegkundige zorg in verandering : een onderzoek naar de gevolgen van integrerende verpleegkunde
}

Citation for published version (APA):

Molleman, H. B. M. (1990). De organisatie van de verpleegkundige zorg in verandering : een onderzoek naar de gevolgen van integrerende verpleegkunde. [Doctoral Thesis, Maastricht University].

Rijksuniversiteit Limburg. https://doi.org/10.26481/dis.19900125hm

Document status and date:

Published: 01/01/1990

DOI:

10.26481/dis.19900125hm

Document Version:

Publisher's PDF, also known as Version of record

Please check the document version of this publication:

- A submitted manuscript is the version of the article upon submission and before peer-review. There can be important differences between the submitted version and the official published version of record.

People interested in the research are advised to contact the author for the final version of the publication, or visit the DOI to the publisher's website.

- The final author version and the galley proof are versions of the publication after peer review.

- The final published version features the final layout of the paper including the volume, issue and page numbers.

Link to publication

\footnotetext{
General rights rights.

- You may freely distribute the URL identifying the publication in the public portal. please follow below link for the End User Agreement:

www.umlib.nl/taverne-license

Take down policy

If you believe that this document breaches copyright please contact us at:

repository@maastrichtuniversity.nl

providing details and we will investigate your claim.
}

Copyright and moral rights for the publications made accessible in the public portal are retained by the authors and/or other copyright owners and it is a condition of accessing publications that users recognise and abide by the legal requirements associated with these

- Users may download and print one copy of any publication from the public portal for the purpose of private study or research.

- You may not further distribute the material or use it for any profit-making activity or commercial gain

If the publication is distributed under the terms of Article 25fa of the Dutch Copyright Act, indicated by the "Taverne" license above, 


\section{DE ORGANISATIE VAN DE VERPLEEGKUNDIGE ZORG IN VERANDERING een onderzoek naar de gevolgen van Integrerende Verpleegkunde}

\section{PROEFSCHRIFT}

ter verkrijging van de graad van doctor aan de Rijksuniversiteit Limburg te Maastricht, op gezag van de Rector Magnificus, Prof. Dr. F.I.M. Bonke, volgens het besluit van het College van Dekanen, in het openbaar te verdedigen op donderdag, 25 januari 1990 om 14.00 uur

$$
\text { door }
$$

Henricus Bernardus Maria Molleman geboren te Lichtenvoorde in 1956 
Promotores:

Prof. Dr. G.J. Kok

Prof. Dr. H. Philipsen

Prof. Dr. A. van Knippenberg

Beoordelingskommissie: Prof. Dr. L. Boon (voorzitter)

Prof. Dr. A.H.M. van den Bergh-Braam

Prof. Dr. M. Grijpdonck

Dr. F. Nijhuis

Prof. Dr. H. Wilke

(C) Eric Molleman

Buro Opleiding, Onderzoek en Ontwikkeling Academisch Ziekenhuis Groningen

produktie: Eric Molleman

druk:Drukkerij Rijksuniversiteit Groningen 


\section{VOORWOORD}

Velen zijn bij de totstandkoming van dit proefschrift betrokken geweest. Ongeveer duizend personen --patiënten, werpleegkundigen en artsen-- hebben een bijdrage geleverd, door het invullen van één of meer vragenlijsten. Daarnaast zijn veel van mijn huidige en vroegere kollega's bij het onderzoek betrokken geweest. Ook een aantal studenten van de vakgroep Sociale Psychologie van de Rijksuniversiteit Groningen, hebben aan het onderzoek meegewerkt. Enkele personen, die een bijdrage hebben geleverd wil ik graag bij name noemen. Bij de opzet van het onderzoek is Prof. Dr. P. Veen nauw betrokken geweest. Hij heeft me meer inzicht gegeven in het verschijnsel 'macht' in theorie en in praktijk. Pine Remmelts en Leo Aukes hebben bijgedragen aan de opzet en uitwoering van het onderzoek. Het onderzoek werd verder mogelijk gemaaks door de medewerking en ondersteuning wan anderen die bij het projekt 'Integrerende Verpleegkunde' waren betrokken. Met name wil ik hier Geert Veenema noemen, die me niet alleen de ruimte heeft gegeven om dit proefschrift te schrijven, maar ook inhoudelijk bij het onderzoek betrokken is geweest. Ook Trees Jordan en Janny Huizinga, die aan de secretariële ondersteuning hebben bijgedragen, wil ik hierbij bedanken. Verder heb ik in de eindfase gebruik gemaakt van de nuttige suggesties, die ik kreeg van Brigit Grol, Geert Veenema, Dicky Ybema, Mieke Voogd en Marcel Bax. Tenslotte wil ik mijn begeleiders Prof Dr. G.J. Kok, Prof Dr. H. Philpsen en Prof Dr. A. van Knippenberg bedanken voor hun wetenschappelijke ondersteuning. Vooral van Ad van Knippenberg, met wie ik ook over andere onderzoeksprojekten heb geschreven, heb ik veel van het 'onderzoeksvak' geleerd.

Eric Molleman

Groningen, 8 november 1989 


\section{INHOUDSOPGAVE}

pagina

1. INLEIDING

1.1 Voorgeschiedenis $\quad 2$

1.2 Integrerende Verpleegkunde 4

1.3 Vraagstellingen 9

2. INTEGRERENDE VERPLEEGKUNDE: DE PATIENT 13

3. DE POSITIE VAN VERPLEEGKUNDIGEN IN DE ORGANISATIE

3.1 De invloed van verpleegkundigen 23

3.2 Macht als 'groeiende koek' 30

3.3 Gevolgen van taakverrüming voor individuele verpleegkundigen

4. METHODE VAN ONDERZOEK

4.1 De selektie van verpleegeenheden $\quad 35$

4.2 Het onderzoeksontwerp 38

4.3 De procedure $\quad 40$

5. DE PATIENT: MATERIAAL EN RESULTATEN 43

$\begin{array}{ll}5.1 \text { De vragenlijsten } & 43\end{array}$

5.2 Selektie en response 46

5.3 De data-analyse $\quad 50$

5.4 Resultaten $\quad 50$

5.5 Samenvatting en diskussie 60 
6.1 De meetinstrumenten $\quad 63$

$\begin{array}{ll}6.2 \text { De respondenten } & 71\end{array}$

$\begin{array}{ll}6.3 \text { Resultaten } & 73\end{array}$

$\begin{array}{ll}\text { 6.4 Samenvatting en diskussie } & 90\end{array}$

7. GEVOLGEN VAN INTEGRERENDE VERPLEEGKUNDE VOOR ANDERE GROEPERINGEN

7.1 Inleiding $\quad 93$

$\begin{array}{ll}7.2 \text { Resultaten } & 94\end{array}$

$\begin{array}{ll}7.3 \text { Samenvatting en diskussie } & 102\end{array}$

$\begin{array}{ll}\text { 8. DISKUSSIE EN KONKLUUSIES } & 107\end{array}$

$\begin{array}{ll}8.1 \text { Overzicht van de resultaten } & 107\end{array}$

$\begin{array}{ll}\text { 8.2 Methodologische evaluatie } & 109\end{array}$

8.3 Theoretische en praktische implikaties 115

$\begin{array}{ll}\text { SAMENVATTING } & 121\end{array}$

$\begin{array}{ll}\text { SUMMARY } & 129\end{array}$

$\begin{array}{ll}\text { LITERATUUR } & 137\end{array}$

$\begin{array}{ll}\text { BIJLAGEN } & 145\end{array}$

CURRICULUM VITAE 154 


\section{HOOFDSTUK 1 INLEIDING}

In de periode 1983 - 1985 heeft er in het Academisch Ziekenhuis Groningen een experiment plaatsgevonden inzake Integrerende Verpleegkunde. In het kader van dit experiment is een evaluatie-onderzoek verricht. In dit onderzoek is nagegaan welke effekten Integrerende Verpleegkunde heeft gesorteerd bij patiënten en verpleegkundigen. In dit proefschrift worden de resultaten van het onderzoek uiteengezet.

In het inleidende hoofdstuk wordt eerst een korte historische schets gegeven van de ontwikkelingen in het beroep van verpleegkundige (1.1). Deze ontwikkelingen zijn de laatste decennia beïnvloed door veranderingen in de organisatorische omgeving waarbinnen de verpleegkundige werkzaamheden worden uitgevoerd, de sterke groei van de technologie en de expansie van de medische wetenschap. De onvrede binnen de verpleegkundige beroepsgroep over deze ontwikkeling is aan het eind van de jaren zeventig mede de aanleiding geweest voor de introduktie van Integrerende Verpleegkunde.

In de tweede paragraaf (1.2) wordt aandacht besteed aan de kenmerken van Integrerende Verpleegkunde en aan de binnen het model gehanteerde begrippen. Daarbij wordt ingegaan op de twee hoofdkenmerken van Integrerende Verpleegkunde. Eén van deze kenmerken --patiënttoewijzing-- refereert aan de wijze waarop taken binnen een verpleegkundige eenheid onder verpleegkundigen worden verdeeld. Het andere kenmerk --het systematisch verpleegkundig handelen-- heeft betrekking op de methode waarmee de taken worden uitgevoerd. In deze paragraaf wordt tevens ingegaan op de in de verpleegkundige literatuur beschreven ervaringen met de introductie van deze en vergelijkbare organisatie- en taakkenmerken in de praktijk.

In de derde en laatste paragraaf van het eerste hoofdstuk zullen de vraagstellingen van het onderzoek worden geformuleerd, waarbij aandacht wordt besteed aan het model, dat in de literatuur werd geintroduceerd. Daarbij komt ook de theoretische onderbouwing van het model aan de orde. In het bijzonder gaat het dan om de kenmerken van het model. Verder wordt nagegaan in hoeverre op grond van de gehanteerde begrippen en hun onderlinge relaties toetsbare hypothesen uit het model kunnen worden afgeleid. Aan het eind van dit hoofdstuk zullen enkele vraagstellingen worden geformuleerd. Deze vraagstellingen hebben betrekking op de gevolgen van Integrerende Verpleegkunde voor de patiënt, de verpleegkundige en de verpleegkundige organisatie.

In het tweede hoofdstuk wordt de vraagstelling, die betrekking heeft op de gevolgen van Integrerende Verpleegkunde voor de patiënt nader uitgewerkt. Uitgangspunten zijn de wijze waarop patiënten tijdens een opname in een ziekenhuis kunnen reageren, en de wijze waarop zij zich volgens Integrerende Verpleegkunde zouden moeten gedragen. Bij de uitwerking van deze vraagstelling wordt gebruik gemaakt van sociaal wetenschappelijke inzichten, met name ontleend aan de aangeleerde hulpeloosheidstheorie en de konformiteitstheorie. Aan het eind van dit hoofdstuk worden hypothesen geformuleerd.

In het derde hoofdstuk wordt nader ingegaan op de wraagstelling die betrekking 
heeft op de gevolgen van Integrerende Verpleeglounde voor zowel individuele verpleeglkundigen als voor de verpleegkundige organisatie. Uitgangspunt is hier de wijze waarop verpleegkundigen hun taken organiseren en uitvoeren, en de samenwer king daarbij met andere leden van de organisatie. Aan de hand van onder andere de 'Expectation States Theory', de machtstheorie en de sociale vergelijkingstheorie zullen verwachtingen worden geformuleerd over de invloed van Integrerende Verpleegkunde op de positie van verpleegkundigen binnen de ziekenhuisorganisatie.

In het vierde hoofdstuk wordt ingegaan op de algehele onderzoeksopzet en de procedures die zijn gevolgd. Aandacht wordt besteed aan de wijze waarop Integrerende Verpleegkunde werd geïntroduceerd, aan de manier waarop de lokaties werden geselecteerd, aan de momenten waarop aan de diverse groeperingen vragen werden voorgelegd en aan de wijze waarop de onderzoeksgegevens werden verzameld. Ook wordt aandacht besteed aan een aantal beslissingen die bij de inrichting van het onderzoek werden genomen en aan de beperkingen van het onderzoek.

In het vijfde hoofdstuk worden de hypothesen getoetst, die handelen over de gevolgen van de introduktie van Integrerende Verpleegkunde voor patiënten. Eerst wordt ingegaan op het meetinstrument dat is gebruikt, en de groep patiënten die aan het onderzoek heeft deelgenomen.

Het zesde hoofdstuk kent een indeling die overeenkomt met de indeling van het vijfde hoofdstuk. Hier worden de hypothesen getoetst die de gevolgen voor de verpleegkundigen betreffen.

Het zevende hoofdstuk stelt de positie van andere groeperingen, zoals de positie wan de verpleegkundige leiding en de positie van artsen, aan de orde.

In het achtste en laatste hoofdstuk worden de resultaten van de voorafgaande hoofdstukken geïntegreerd, en worden praktische, theoretische en methodologische implikaties wan deze studie toegelicht.

\subsection{Voorgeschiedenis}

Deze paragraaf biedt een korte schets van het ontstaan van en de ontwikkelingen in het verpleegkundig beroep. Dit overzicht moet beslist miet gezien worden als een historische analyse: het is vooral de bedoeling op enkele veranderingen te wijzen die in het verleden hebben plaatsgevonden, en die de ontwikkeling van het model Integrèrende Verpleegkunde hebben gestimuleerd.

\section{Het ontstaan van ziekenhuizen}

In haar kulturhistorische beschouwing over de verpleegkundige professie beschrijft Van Eindhoven (1980) de oorsprong van de verpleegkundige werkzaamheden. Deze is gelegen binnen het farnilie-verband. Het waren de vrouwen die zich binnen het gezin toelegden op de verzorging van zieken. Aan het eind van de middeleeuwen ontstonden er gasthuizen waar door religieuzen onder andere chronisch zieken werden verzorgd. Het betrof met name zieken bij wie de familie door armoede niet in staat was de zorg op zich te nemen, zwervers en alleenstaanden. Door de medische ontwikkeling nam sinds de negentiende eeuw het aantal behandelingsmogelijkheden toe. Hierdoor ontstond er meer behoefte aan intramurale instellingen en (beter) opgeleide 
verzorgenden. Het verpleegkundig en medisch ambacht hebben zich tot die tijj voornamelijk onafhankelijk van elkaar ontwikkeld (Querido, 1960). Pas aan het eind van de negentiende eeuw doen de medici in grote getale hun intrede in de instellingen voor ziekenverzorging. Vanaf die tijd kunnen we spreken van ziekenhuizen.

\section{Artsen en verpleegkundigen}

De artsen krijgen in de ziekenhuizen meer aanzien en invloed, met name omdat de medische behandeling meer en meer centraal komt te staan. Door de explosieve groei van de medische wetenschap sinds het begin van deze eeuw wordt de positie van de medici versterkt. Hun behandeling staat centraal en de verpleegkundige verzorging wordt meer een afgeleide daarvan. Uit een studie over de verpleegkundige professie in de twintiger jaren blijkt bijvoorbeeld, dat de invloed van de medici op de verpleegkundige (inservice-)opleidingen al vanaf het begin van deze eeuw groot is (Keddy, Jones Gillis, Jacobs, Burton \& Rogers, 1986). Met name in de ziekenhuizen worden de verpleegkundige taken afgeleid van de medische behandeling. Door de technologische ontwikkelingen verandert de inhoud van de verpleegkundige werkzaamheden. Lag de nadruk aan het begin van deze eeuw nog op het huishoudelijk werk en de verzorging van patiënten, in de loop van deze eeuw zijn de huishoudelijke werkzaamheden geheell naar de achtergrond verdwenen en is het aantal (verpleeg)technische verrichtingen enorm toegenomen (zie bijvoorbeeld Tammeling, 1978). De behandeling (cure) heeft --onder invloed van de techniek-- in de ziekenhuizen inmiddels ook de verzorging (care) verdrongen (De Vries-Griever, Schmidt, Van Ekeren \& Meijman, 1985). De verpleegkundige zorg is vanaf het begin van deze eeuw onderdeel geworden van de totale zorg, waarvoor de arts de eindverantwoordelijkheid draagt. Verplegen is daarmee voornamelijk verworden tot het adekwaat uitvoeren van de opdrachten van de arts. "Worthiness was equated with helpfulness to the doctors, (...)" (Keddy, et al., 1986, p. 746). "Good nursing care was often equated with efficient fulfilment of doctor's orders" (Kalisch \& Kalisch, 1977, p. 50). De arts stelt zowel de verpleegkundige zorgvraag vast als ook de kwaliteitskriteria woor die zorg.

\section{De verpleegkundige beroepsontwikkeling}

In de jaren vijftig komen vanuit de Verenigde Staten en Engeland de eerste signalen die wijzen op een emancipatie van de verpleegkundigen in de ziekenhuizen. Ervaringen met teamverpleging, planmatig werken, standaarden voor de verpleegkundige zorg en de effekten hiervan op de opnameduur en het kontakt tussen de verpleegkundige en de (familie van de) patiënt, worden voor het eerst beschreven (cf. Jenkinson, 1958). Deze resultaten hebben wooralsnog geen grote invloed op de verpleegkundige beroepsontwikkeling. Uit een studie van Hofling, Brotzman, Dalrymple, Graves en Pierce (1966) waarin naar aanleiding van de 'gehoorzaamheidsstudies' van Milgram (1963) nagegaan wordt, in welke mate verpleegkundigen opdrachten van artsen klakkeloos uitvoeren, blijkt bijvoorbeeld dat van de 22 verpleegkundigen die werden benaderd, er 21 bereid zijn een telefonische opdracht van een onbekende arts uit te voeren betreffende het toedienen van tweemaal de maximaal-toegestane dosis van een medikament; in werkelijkheid voerden de verpleegkundigen de opdracht niet uit, omdat zij vóór de feitelijke toediening over het experiment werden geïnformeerd. Uit een studie van Austin (1978) naar de motivatie van verpleegkundigen blijkt, dat in het 
midder wan de jaren zewentig verpleegkundigen nog veel sterker beloningen nastreven die kenmerkend zijn woor een altruistische instelling (bijvoorbeeld dankbaarheid en respekt van patienten en kollega's) dan voor een professionele houding (invloed, inkomen, kennis, Joopbaan). "Nurses, then, not only give a low ranking to professional membership as a work reward, but the distribution of variables associated with professional membership are not those generally connected with the professional claim" (Austin, 1978, p.22).

In de tweede helft van de jaren $70 \mathrm{komt}$ de ontwikkeling wan de verpleegkundige professie in een stroomversnelling. De demokratiseringsbeweging, de vrouwenemancipatie en het ontstaan, in Nederland, van dagschoolopleidingen en doktoraalopleidingen voor verpleegkundigen, vormen een geschikte voedingsbodem voor de verpleegkundige beroepsontwikkeling. De demokratisering heeft er bijvoorbeeld toe bijgedragen, dat de (minder machtige) werpleegkundige meer bij het patiëntenzorgbeleid wordt betrokken. Mede doordat er meer mannen voor het verpleegkundige beroep kozen en door veranderingen in de arbeidsmarkt, ging de verpleegkundige beroepsgroep minder bestaan uit mensen die 'tot hun huwelijk' als verpleegkundige werkzaam zijn. Als gevolg van de oprichting van dagschoolopleidingen vindt de vorming van verpleegkundigen minder bininen de ziekenhuiscultuur plaats (cf. De Ruiter \& Visser, 1983). Binnen de beroepsgroep ontstaan aanzetten tot verpleegkundige theorievorming (zie bijvoorbeeld Orem, 1971; Dickoff \& James, 1968). Nadat in 1951 het eerste wetenschappelijke tijdschrift woor verpleegkundigen, 'Nursing Research', verschijnt, groeit het aantal tijdschriften in deze periode sterk, bijwoorbeeld het 'International Joumal of Nursing Studies' (1963), het 'Journal of Advanced Nursing' (1975) en de 'Research in Nursing and Health' (1977).

De verpleegkundigen bevinden zich echter in een dualistisch machtssysteem. Zij moeten enerzijds steeds meer verantwoordelijkheid dragen en risicovolle (medische) verrichtingen uitvoeren, terwijl anderzijds hun invloed op de zorg, hun autonomie en de ruimte om zelfstandig te beslissen niet of nauwelijks toenemen (Georgopoulas, 1974). Dit veroorzaakt spanningen, emotionele uitputting, ontevredenheid, onzekerheid en een ambigue houding tegenover de eigen verpleegkundige rol, een groter ziekteverzuim en meer verloop (Simpson \& Sears, 1985; Maslach \& Jackson, 1982; Keirse, 1987; Katz \& Kahn, 1978).

\subsection{Integrerende Verpleegkunde}

\section{Introduktie}

Integrerende Verpleegkunde kan beschouwd worden als een reaktie op de verschuiving en de verbreding wan de verpleegkundige werkzaamheden die thet gevolg zijn var medische en technologische ontwikkelingen. De verpleegkundige taken zijn niet alleen inhoudelijk veranderd --eerst lag de nadruk op huishoudelijke werkzaamheden, vervolgens op verzorgende werkzaamheden en tegenwoordig op verpleegtechnische verrichtingen--, maar ook meer omvangrijk en komplexer geworden. Dit heeft de nodige horizontale en vertikale taakspecialisatie tot gevolg gehad. Verschillende verpleegkundigen verrichten onathankelijk van elkaar aktiviteiten die gericht zijn op de diverse deelproblemen van én en dezelfde patiënt. Hierdoor is er niet voldoende 
aandacht woor de mogelijkheid dat deelproblemen met elkar samenhangen of met elkaar interfereren (bijvoorbeeld stress en lichamelijk berstel). Grypdonck (1988) stelt deze samenhang vanuit een humanistische en "holistische" mensvisie centrat en legt de nadruk op de integratie van de verschillende zorgvragen van patiënten in de verpleegkundige zorg. Veen (1982) stelt: "Opsplitsing van taken in deeltaken vindt vooral plaats om redenen van efficiëntie. De grotere routine die bij deelhandelingen ontstaat, leidt tot een groter rendement" (p. 169). Dit kan echter bij een verpleegkundige onteviedenheid over zijn of haar ${ }^{l}$ werkzaamheden veroorzaken, waardoor de produktiviteit afneemt en de taakdifferentiatie zijn doel voorbij schiet. Grypdonck (1988) pleit voor een grotere verantwoordelijkheid voor individuele verpleegkundigen, waarbij beslissingen over de verpleegkundige zorg zo 'laag' mogelijk in de organisatie worden genomen, daar namelijk waar ook de uitwoering van die zorg plaatsvindt.

Eerst worden twee belangrijke elementen van Integrerende Verpleegkunde besproken. Vervolgens wordt ingegaan op de veranderingen die het gevolg zouden moeten zijn van de implementatie van deze elementen. Tenslotte worden in deze paragraaf enkele studies besproken waarin onderdelen van Integrerende Verpleegkunde of vergelijkbare modellen onderwerp van onderzoek zijn geweest.

Twee instrumenten. In het model Integrerende Verpleegkunde worden twee hoofdinstrumenten onderscheiden die effekten bij de patiënt en bij de verpleegkundige (-organisatie) zouden moeten veroorzaken (Koene, Grypdonck, Rodenbach \& Windey, 1980), namelijk 'patiënttoewijzing' en 'het systematisch verpleegkzundig handelen'. We zullen deze twee elementaire instrumenten in het kort bespreken.

1. Bij patiënttoewijzing krijgen verpleegkundigen geen taken toegewezen, waardoor zij bij een groot aantal patiënten een beperkt aantal taken uitvoeren. Zij krijgen patiënten toegewezen bij wie zij zo veel mogelijk verpleegkundige taken uitvoeren. Eén verpleegkundige is verantwoordelijk voor de totale verpleegkundige zorg van een patiënt. In Figuur 1-1 wordt de werkverdeling bij patiënttoewijzing en bij taaktoewijzing op vereenvoudigde wijze weergegeven.

Onder Integrerende Verpleegkunde zou de verpleegkundige leiding op grond van de zorgvraag van een patiënt en wan de deskundigheid van een verpleegkundige patiënten aan verpleegkundigen moeten toewijzen. De verpleegkundige kan echter niet kontinu bij een patiënt aanwezig zijn en alle handelingen zelf uitvoeren. Wel zou ze de verantwoordelijkheid moeten krijgen voor de verpleegkundige zorg, doordat ze samen met de patiënt de verpleegkundige vraagstellingen en doelstellingen waststelt, en een daarbij passend aktiviteitenplan opstelt (verpleegplan). Er wordt gestreefd naar een verpleegkundige zorg, waarbij de patiënt aktief betrokken wordt en participeert. Een verpleegkundige heeft hierin wel een andere rol dan de patiënt. Van hem of haar worden de nodige kennis en vaardigheden verwacht, alsmede het vermogen initiatief te nemen in het overleg met de patiěnt. De

${ }^{I}$ In deze dissertatie worden mannelijke en vrouwelijke aanduidingen door en naast elkaar gebruikt. Daar waar alleen mannelijke aanduidingen worden gebruikt, mogen ook vrouwelijke aanduidingen worden gelezen en vice versa. 
mate waarin een patient kan participeren in de zorg zal van patiënt tot patient, van situatic tot situatie en van moment tot moment sterk uiteenlopen (vergelik Krantz, Baum \& Wideman, 1980).

De koördinerende rol van de verpleegkundige binnen de Integrerende Werpleegkunde if het direkte gevolg van patiënttoewijzing. Koördinatie refereert -gelet op de achterliggende 'holistische' mensvisie-- aan het afstemmen van de verschillende deeltaken aangaande een patiënt, aan de planning van deze aktiviteiten en aan de koördinatie van de aktiviteiten van verschillende disciplines betreffende éen en dezelfde patiënt. "De kem van hel hele herorienteringsvoorstel ligt hierin, dat men de verpleegkundige de verantwoordelijkheid geefi voor de totale verpleegkundige zorg van een beperkt aantal patiënten" (Koene et al., 1980, p. 18).

\begin{tabular}{|c|c|c|c|c|c|c|}
\hline & \multicolumn{6}{|c|}{ Taakto ewijzing } \\
\hline & verpl & 1 & verpl & 2 & verpl & 3 \\
\hline patient & taak & 1 & taak & 2 & taak & 3 \\
\hline patten: & taak & 1 & talak & 2 & taak & 3 \\
\hline patient & taak & 1 & taak & 2 & taak & 3 \\
\hline 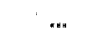 & $\ldots$ & & .6. & & $\cdots$ & \\
\hline 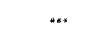 & $\ldots$ & & $\ldots$ & & $\ldots$ & \\
\hline
\end{tabular}

\begin{tabular}{|c|c|c|c|c|c|}
\hline & \multicolumn{5}{|c|}{ Patienttoewijzing } \\
\hline & verpl & 1 & verpl & 2 & verpl 3 \\
\hline taak & pat & 1 & pat & 2 & pat 3 \\
\hline taak & pat & 1 & pat & 2 & pat 3 \\
\hline taak & pat & 1 & pat & 2 & pat 3 \\
\hline$\ldots$ & $\ldots$ & & $m$ & & $\ldots$ \\
\hline$\ldots$ & $\ldots$ & & $\ldots$ & & $\ldots$ \\
\hline
\end{tabular}

Figuur 1-1. Vereenvoudigde weergave van de organisatie van de werpleegkundige zorg met taaktoewijzing en met patiènttoewijzing(pat = patient en verpl=verpleegkundige).

2. Systematisch verpleegkundig handelen. In tegenstelling tot routinematig werken staat hier het rationeel, weloverwogen en planmatig handelen centraal. Op grond wan de kennis van de verpleegkundige, en in overleg met de patiënt, wordt de zorgbehoefte vastgesteld, worden de doelen van de zorg geformuleerd, wordt een plan voor de uitvoering gemaakt, wordt de zorg uitgevoerd, geèvalueerd en wordt zonodig het plan bijgesteld. "Het systematisch verpleegkundig handelen beoogt op gesystematiseerde en geintegreerde wijze de patiëntenzorg te plannen, uit te voeren en te evalueren. Het systematisch verpleegkundig handelen is niet de toepassing van een bepaalde techniek, maar fundamenteel de uitdrukking van een wetenschappelijke houding van een verpleegkundige tegenover het eigen werk. "(...) In integrerende Verpleegkunde wil men de beoefening van verpleegkunde op professioneel niveaw mogelijk maken. Systematisch verpleegkundig handelen is daartoe een insthment" (Koene et al., 1980, p. 47 en 49).

Doelen van Integrerende Verplegkande. In de uiteenzetting van het model Integrerende Verpleegkunde wordt vrij veel aandacht besteed aan de hierboven genoemde twee hoofdkenmerken. Deze kenmerken betreffen de organisatie van de 
verpleegkundige werkzaamheden en de verpleegkundige werkmethode. Slechts summier spreekt men zich uit over de inhoud van de verpleegkundige werkzaamheden. Ook de doelen worden nauwelijks uitgewerkt of gespecificeerd. Het model beoogt volgens hen (Grypdonck, Rodenbach \& Windey, 1977; Koene et al, 1980):

1. een verhoging van de kwaliteit van de verpleegkundige zorg;

2. professionalisering van de verpleging;

3. het stimuleren van de ontwikkeling van indiwiduele verpleegkundigen.

$\mathrm{Zij}$ stellen dat Integrerende Verpleegkunde door integratie van de diverse verpleegkundige zorgvragen kwaliteitsverhoging nastreeft. Bij deze integratie wordt de patiënt betrokken. "Verpleegkundige zorg beoogt de patiënt te begeleiden naar en te stimuleren tot een zo hoog mogelijk niveau van zelfzorg" (Koene et al., 1980, p. 16). Integrerende Verpleegkunde wil naast verbetering van de zorg "(...) aan de opkomende professionalisatie van her verpleegkundige beroep een organisatorisch kader bieden" (Koene et al., 1980, p. 14). Integrerende Verpleegkunde pretendeert het vergroten van de autonomie en de zelfstandigheid van individuele verpleegkundigen en het bevorderen van de verpleegkundige beroepsontwikkeling. Dit impliceert dat verpleegkundigen minder vanuit de 'verlengde arm' gedachte funktioneren, maar meer invloed krijgen op de formulering van doelstellingen in de patiëntenzorg. Binnen deze doelstellingen dienen verpleegkundige doelstellingen (b.w. het bevorderen van zelfzorg) die niet (volledig) van de doelstellingen van andere disciplines afgeleid kunnen worden, gerealiseerd te kunnen worden. Genoemde auteurs, die het model in het Nederlandse talgebied hebben geïntroduceerd, geven zelf aan, dat zij de doelen van Integrerende - Verpleegkunde slechts globaal aangeven: "Het voorstel voor heroriëntering bevat alleen de grote lijnen voor een reorganisatie. De principes die hierna naar voren worden gebracht zijn niet valdoende om tot een funktionerende organisatie van de verpleegeenheid te komen. Daarvoor dienen de principes te worden omgezet in werkwormen die in een konkrete werkomgeving passen. (...) Het is een model in de zin van een geschematiseerde weergave van de realiteit, waarbij alleen de grore lijnen, niet de details, zijn aangegeven" (Koene et al., 1980, p. 17 en 18). Boschma (1988, p. 17) konkludeert in haar wetenschapsfilosofjsche beschouwing over het model: "Voor de vragen die de verpleegkundige heeft op inhoudelijk terrein kan ze niet bij de theorie over Integrerende Verpleegkunde terecht".

We kunnen vaststellen dat in de literatuur de achterliggende mensvisie en de belangrijkste instrumenten van Integrerende Verpleegkunde voldoende helder worden aangegeven. Dit geldt in mindere mate voor de gevolgen van de introduktie van het model voor de inhoud van de verpleegkundige werkzaamheden en voor de gevolgen voor patiënten. Het model, voor zover nu behandeld, biedt onvoldoende aanknopingspunten voor de formulering van toetsbare verwachtingen.

\section{Enkele studies}

In de verpleegkundige literatuur worden enkele studies beschreven die betrekking hebben op patiënttoewijzing of op het systematisch verpleegkundig handelen. We zullen nu nagaan of deze literatuur meer inzicht geeft in de mogelijke effekten van Integrerende Verpleegkunde.

Patiëntoewijzing. In de Verenigde Staten werden de eerste ervaringen opgedaan met patiënttoewijzing (Jones, 1977 ; Jones, 1977; Plumpton, 1978). Door patiënttoewijzing 
moeten patiènt en verpleegkundige meer de gelegenheid krigen om hun kontakt te verdiepen. Wanneer patienten hierdoor meer vertrouwen krijgen in hun verpleegkundige, zullen zij meer bereid zijn hun eigen mening en persoonlijke zorgbehoefte te uiten. Meer rumte woor persoonlijk kontakt tussen de verpleegkundige en patiênt verhoogt de kwaliteit van de zorg (Moss, 1984). Bij deze eerste "experimenten' vindt patie̊nttoewijzing elke dag opnieuw plaats. De effekten van patiënttoewijzing worden echter niet systematisch onderzocht: auteurs geven hun eigen ervaringen en de ervaringen van kollega's weer. Uit hun praktijkervaringen komt bijwoorbeeld naar voren, dat

- patiènttoewijzing niet strikt gehanteerd kan worden, omdat bijvoorbeeld sommige verrichtingen niet door éen verpleegkundige gedaan kunnen worden; - de rol van de verpleegkundige leïding drastisch verandert door patiënttoewijzing; - patiëntoewijzing de doelmatigheid en de kwaliteit van de verpleegkundige zorg verhoogt, doordat taken niet meer dubbel worden verricht en bepaalde minder aantrekkelijke taken door een verpleegkundige niet meer kunnen worden vermeden. "Time and effort on the part of the nurses were repeatedly wasted as no one was sure who had done what; jobs were re-done or re-checked by perhaps two or more anxious, conscientious nurses, while other essential items were overlooked because it was no-one's specific responsibility (...)" (Plumpton, 1978, p. 417). Omdat een verpleegkundige door patiènttoewijzing verantwoordelijk is voor de totale verpleegkundige zorg van een patiënt, zal de bereidheid bij de verpleegkundige toenemen om in te gaan op elke --ook de minder aantrekkelijke-- zorgvraag wan een patiënt (vergelijk studies over de diffusie van verantwoordelijkheid en de bereidheid hulp te verlenen, zoals Darley \& Latané, 1968; Piliavin, Piliavin \& Rodin, 1975);

- verpleegkundigen een grotere verantwoordelijkheid ervaren en beter in staat zijn hun werk te plannen, waardoor de efficièntie toeneemt (vergelijk onderzoek over taakkomplexiteit en de mate van centralistisch leiderschap: Fiedler, 1967; Faucheux \& Mackenzie, 1966; Chemers, Hays, Rhodewalt \& Wysochi, 1985; Bodt \& Tuijl, 1985).

Systematisch verpleegkundig handelen. Aan het eind van de jaren zeventig verschijnen de eerste publikaties waarin naast patiënttoewijzing ook aandacht wordt besteed aan het verpleegkundig proces. Voor de term 'verpleegkundig proces" worden in de literatuur een aantal synoniemen gehanteerd, zoals 'methodisch verplegen', 'systematisch verpleegkundig handelen', 'probleemoplossend verplegen'. Wij zullen in navolging van Koene et al. (1980) de term 'systematisch verpleegkundig handelen' gebruiken. Het proces heeft grote overeenkomsten met de empirisch-wetenschappelijke onderzoekscyclus (zie bijwoorbeeid De Groot, 1961). "The Nursing Process is a logical and systematic approach to nursing care (...). The Nursing Process is comprised of certain steps involved in assessing patien's's needs, identifying his problems, identifying the objectives or expected outcomes of the problems, writing a care plan to solve the problems, giving the nursing care as stated in the care plan, and evaluating the care which has been given to see if the expected outcomes have been met. The Nursing Process enables a constant feedback of information so that solved problems can be deteted from the care plan and new problems dealt with as they occur" (Marks-Maran, 1978, p. 413 en 414). Verpleeg- 
kundigen formuleren in het verpleegkundig proces probleemstellingen (zorgvragen), stellen doelen wan de verpleegkundige zorg vast, plannen de zorg, voeren deze uit en gaan na of de doelen zijn bereikt (evaluatie). De probleemstelling wordt eventueel bijgesteld, en de verschillende stappen worden opnieuw doorlopen. Op deze wijze ontstaat een cyclisch proces.

Metcalf (1986) treft minimale effekten van patiënttoewijzing aan, terwijl uit een onderzoek van Miller (1985) blijkt dat patiënttoewijzing samen met systematisch verpleegkundig handelen leidt tot minder afhankelijkheid van patiënten, een kortere verblijfsduur en een lagere mortaliteit. Berry en Metcalf (1986) onderscheiden, naast patiënttoewijzing en het procesmatig verplegen, het patiëntgericht ('patient-centered') verplegen, waarbij de patiënt aktief bij het proces wordt betrokken. Uit hun onderzoek komt naar voren dat patiënttoewijzing en procesmatig verplegen vooral positieve effekten sorteren bij de verpleegkundige. De gevolgen voor de patiënt zijn minimaal (zie ook Richards \& Lambert, 1987). Zij wijzen erop dat, met name indien de patiënt betrokken wordt bij zijn verzorging, dit positieve effekten bij de patiënt veroorzaakt. Uit een studie van Kitson (1986) blijkt dat de kwaliteit van de verpleegkundige zorg in een geriatrische instelling sterk samenhangt met het patiëntgericht en therapeutisch werken door verpleegkundigen. De kwaliteit van de zorg werd daarbij gemeten in termen van de onafhankelijkheid van de patiënt en het verrichten door de patiënt van zelfzorgaktiviteiten (eten, wassen, aan- en uitkleden, baden, zich verplaatsen, gesprekken voeren).

Macdonald (1988) geeft een overzicht van studies naar 'Primary Nursing', een met Integrerende Verpleegkunde vergelijkbaar model. Wat de 'effekt-studies' betreft, onderscheidt zij variabelen die 'de tevredenheid onder verpleegkundigen', 'tevredenheid bij patiënten', 'de kwaliteit van zorg' en 'ekonomische variabelen' betreffen. Al deze studies worden volgens haar gekenmerkt door meettechnische en andere methodologische tekortkomingen. $\mathrm{Zjj}$ stelt daarbij vast dat 'tevredenheid' het minst bruikbare kriterium is, mede omdat patiënten, vanwege hun afhankelijkheid van verpleegkundigen tijdens het verblijf in het ziekenhuis, en ongeacht de organisatie en de inhoud van de verpleegkundige zorg, meestal tevreden tot zeer tevreden zijn. Ten aanzien van de invloed van 'primary nursing' op de kwaliteit van de zorg konstateert ze meer uniformiteit in het gebruik van meetinstrumenten, minder methodologische problemen en meer konsistente resultaten. De meeste studies wijzen op een hogere kwaliteit van de zorg (zie bijwoorbeeld Wilson \& Dawson, 1989).

De hierboven aangehaalde literatuur wijst uit dat veranderingen in de verpleegkundige organisatie of de verpleegkundige werkmethode vooral, effecten sorteert bij verpleegkundigen. Effecten bij patiënten worden voornamelijk aangetroffen wanneer verpleegkundigen tijdens interakties participatie van patiënten stimuleren. Bovendien werd duidelijk dat we ons bij de formulering van onderzoeksvragen niet moeten richten op de tevredenheid van patiënten met de verpleegkundige zorg of op de arbeidstevredenheid van verpleegkundigen.

\subsection{Vraagstellingen}

De auteurs die het Integrerende Verpleegkunde model hebben geïntroduceerd, maken --zoals gezegd-- geen gedetailleerde analyse van de aard van de gevolgen van 
Integrerende Verpleegkunde voor patiěnten en verpleegkundigen en van de wijze warop deze effekten tot staind komen. Mede op grond vain hetgeen hierboven werd besproken, kunnen we enkele vraagstellingen formuleren over de mogelijke gevolgen van Integrerende Verpleegkunde voor patiënten en verpleegkundigen. De nu volgende overwegingen lijken daarbij van belang.

\section{De patiënt}

Ziekte gaat veelal gepaard met verlies van invloed op een aantal terreinen. Men kan bepaalde lichamelijke prestaties niet meer leveren, men kan voor zichzelf geen voedsel meer bereiden of bij vrienden op bezoek gaan. Bij opname in een ziekenhuis treedt verder inwloedsverlies op. Men komt meestal op een kamer te liggen met andere patiënten die men niet zelf heeft kunnen uitkiezen. Gebrek aan privacy betekent een gebrek aan mogelijkheden om interpersoonlijke kontakten te reguleren, waardoor men ongewild gekonfronteerd wordt met onbekenden en hun bezoekers. Patiënten hebben ook een beperkte invloed op interakties met artsen en verpleegkundigen. Invloed op interakties met deze hulpverleners is echter van cruciaal belang, omdat juist gedurende het kontakt met hen afspraken gemaakt kunnen worden die het verlies van invloed op andere terreinen, zoals voeding, mobiliteit, het ontvangen van bezoek, en privacy, beperken.

Verondersteld kan worden, dat door patiënttoewijzing verpleegkundigen en patiënten meer de gelegenheid krijgen om hun kontakt te verdiepen. Omdat een patiënt weet met wie hij over zijn zorg(en) kan praten, en hij 'zijn' verpleegkundige beter zal leren kennen, zal de patiënt waarschijnlijk eerder geneigd zijn, zijn wensen naar voren te brengen; dit ook ter aanzien van de niet-somatische zorgen. In een ziekenhuis, dat zich primair richt op somatische problemen, ligt het in de rede dat patiënten somatische problemen (pijn, lichamelijke kJachten) maar voren brengen. Bij niet strikt-somatische klachten --die veelal aan de somatische problemen zijn gerelateerd-- ligt dit minder voor de hand. Problemen als 'angst voor een mutilerende ingreep' of 'een partner die de ziekte niet accepteert', zullen minder snel door een patiënt naar voren worden gebracht, te minder wanneer deze voortdurend met wisselende hulpverleners in kontakt komt. Bij patiënttoewijzing bestaat evenwel de mogelijkheid dat een patiënt en een verpleegkundige -on welke reden dan ook-- elkaar niet goed liggen. In dergelijke situaties is het gewenst dat de patiënt aan een andere verpleegkundige wordt toegewezen. In deze studie wordt aan een dergelijke situatie verder geen aandacht besteed. Het betreft een situatie die zich overigens ook bij andere disciplines, zoals medici, diètisten en fysiotherapeuten, kan voordoen.

Voor een patient betekent patiënttoewijzing, dat deze met minder verschillende verpleegkundigen hoeft te kommuniceren, en meer zekerheid krijgt over met welke verpleegkundigen interacties gevoerd zullen worden. Omdat verpleegkundigen binnen Integrerende Verpleegkunde de patiènt bovendien zo veel mogelijk bij het vaststellen van de zorgbehoefte, de witvoering van de zorg en de evaluatie van de zorg betrekken, verwachten we dat patiënten meer invloed op de zorg gaan ervaren.

\section{De verpleegkundigen}

Integrerende Verpleegkunde beoogt integratie van de zorg, dat wil zeggen dat de verpleegkundige aandacht moet hebben voor somatische, emotionele, sociale en andere 
zorgwragen, en dat een verpleegkundige rekening moet houden met de mogelijkheid dat deze elkaar onderling versterken of beïnvloeden. Bij het beantwoorden wan de zorgvragen zal de verpleegkundige een integrale zorg moeten nastreven, zodat niet bijwoorbeeld problemen op het ene terrein worden opgelost, terwijl problemen op een ander terrein bljwen liggen of zelfs worden vergroot. Dit betekent dat de verpleegkundige verantwoordelijk wordt voor de koördinatie van de verpleegkundige zorg voor een patiënt en de verpleegtechnische, verzorgende, psycho-sociale en administratieve handelingen die een patiënt betreffen, op elkaar moet afstemmen. De koördinerende taak brengt aok met zich mee dat de samenwerking met de verpleegkundige leiding, de kollega's en met andere disciplines aan verandering onderhevig is. Met artsen zal vaker, zonder tussenkomst van de verpleegkundige leiding, overlegd moeten worden. De verpleegkundige zal voor een goede informatie-overdracht moeten zorgen, opdat kollega's in de avond- of nachtdienst voldoende over een patiënt zijn geïnformeerd. Verwacht kan worden dat niet alleen patiënten, maar ook kollega's en andere disciplines een groter appèl zullen doen op de verpleegkundige.

Integrerende Verpleegkunde brengt weranderingen met zich mee in de werkzaamheden, de taakverdeling, de verantwoordelijkheden en de bevoegdheden. Zo wordt de verpleegkundige verantwoordelijk woor een goede planning en koördinatie van de verpleegkundige verzorging van de aan hem/laar toegewezen patiënten. Wat voorheen de taak van de verpleegkundige leiding was, gaat nu tot het takenpakket van de verpleegkundige behoren. De arts zal, wanneer hij vragen heeft over een patiënt, meer afhankelijk zijn van een verpleegkundige. Omdat verpleegkundigen door Integrerende Verpleegkande een meer centrale positie innemen in (de kommunikatie over) de patiëntenzorg, wordt verwacht, dat de verpleegkundige meer invloed krijgt op de patiëntenzorg.

Integrerende Verpleegkunde impliceert taakverruiming in de vorm van ondermeer psychosociale zorg, koördinatie van werkzaamheden, integratie van zorg en samenwerking met andere disciplines. Taakverruiming heeft over het algemeen een positieve invloed op de tevredenheid over het werk en op de arbeidsmotivatie (zie bijvoorbeeld Veen, 1982). Van de andere kant vraagt takkverruiming om meer vaardigheden en kennis van individuele verpleegkundigen. Uit een studie van Aukes, Baving \& Molleman (1987) naar het funktioneren van verpleegkundigen gedurende het eerste $1 \frac{1}{2}$ jaar na hun aanstelling in een ziekenhuis als gediplomeerd verpleegkundige, blijkt dat zij 'de begeleiding van patiënten' erg belangrijk vinden. Er bestaat onder hen echter weinig duidelijkheid over de zorgvragen die daarbij relevant zijn, hoe die gesignaleerd kunnen worden, hoe deze vragen opgelost dienen te worden en welk doel men daarbij voor ogen moet hebben. Het is mogelijk dat Integrerende Verpleegkunde op genoemde taakgebieden onzekerheid zal veroorzaken. De mate waarin onzekerheid zich za] manifesteren, zal mede afhangen van de senioriteit van de verpleegkundige, dat wil zeggen: het deskundigheidsnivo, de ervaring en de genoten opleiding van de verpleegkundige. Door patiënttoewijzing wordt bovendien de verantwoordelijkheid minder diffuus. Wanneer een verpleegkundige onzekerheid ervaart, en bemerkt dat hij of zij de hogere eisen die er aan hem of haar gesteld worden niet kan waar maken, dan zal de verpleegkundige de situatie als bedreigend kunnen gaan ervaren. Verwach wordt dat de introduktie van Integrerende Verpleegkunde bij verpleegkandigen onzekerheid veroorzaakt en dit minder, naarnate de senioriteit van de verpleegkundige toeneemt. 


\section{Samenvatuing}

In dit eerste hoofdstuk werd in het kort ingegaan op de geschiedenis en de ontwikkeling wan het verpleegkundige beroep, de belangrijkste kennerken van Integrerende verpleegkunde en enkele studies warin elementen van dit of vergelijkbare modellen werden onderzocht. Vastgesteld werd dat in de literatuur de inhoud van de fundamentele kemmerken van Integrerende Verpleegkunde redelijk duidelijk. beschreven wordt. Dit in tegenstelling tot de effekten die die introduktie van (onderdelen van) dit model dienen te bewerkstelligen bij patiènten, verpleegkundigen of anderen. De effekten worden slechts in algemene zin aangegeven. Aan de wijze watrop de onderdelen van het model effekten zouden moeten bewerkstelligen, wordt nog minder aaridacht besteed. Een theoretische onderbouwing ontbreekt, maar is niettemin gewenst om te kunnen komen tot specifieke voorspellingen over de te verwachten effekten van Integrerende Verpleegkunde. In hoofdstuk 2 wordt zo'n theoretische analyse van de te verwachten effekten bij patiënten geboden. In het derde hoofdstuk gebeurt dit ten aanzien van de gevolgen van Integrerende Verpleegkunde voor verpleegkundigen. 


\section{HOOFDSTUK 2 \\ INTEGRERENDE VERPLEEGKUNDE: DE PATIENT}

\section{Inleiding}

In het eerste hoofdstuk werden de gevolgen van een opname in een ziekenhuis voor de patient beschreven aan de hand van het begrip "invloedsverlies". Hoewel er geen studies bekend zijn over de wijze waarop Integrerende Verpleegkunde het verlies aan invloed beperkt, zijn er wel enkele onderzoeken waarin de gevolgen van een ziekenhuisopname in een situatie zonder Integrerende Verpleegkunde worden besproken. In deze literatuur wordt een ziekenhuis-organisatie beschreven als een systeem waarbinnen patiënten afhankelijk worden gemaakt hetgeen kan leiden tot depersonalisatie van patiënten. In dit hoofdstuk wordt eerst deze literatuur besproken om verwolgens aan de hand ervan een theoretisch kader te formuleren, warbinnen twee meer specifieke begrippen uit het eerste hoofdstuk, 'invloed' en 'zelfzorg', geplaatst kumnen worden. Daarna worden verwachtingen en hypothesen geformuleerd over de gevolgen van Integrerende Verpleegkunde voor de patiënt. Het gaat daarbij om die gevolgen, waardoor dit verpleegmodel zich onderscheidt van meer klassieke werkvormen (veelal aangeduid als 'taakgericht' of 'funktioneel' verplegen).

\section{Gevolgen wan een ziekenhuisopname}

Het gedrag van patiënten gedurende hun verblijf in een ziekenhuis is door Taylor (1979) beschreven. Zij schildert het ziekenhuis af als een systeem waarbinnen het produktieproces zodanig georganiseerd is dat, hoewel afhankelijkheid en depersonalisatie van een patiënt geen doel zijn, er van de patiërnt nawwelijks een aktieve ro] wordt verwacht. De patiënt voelt zich daardoor overgeleverd en niet (meer) verantwoordelijk voor het verloop van de behandeling. "The hospital is one of the few places where an individual forfeits control over virtually every task he or she customarily performs" (Taylor, 1979, p. 157). Dit kan weerstand oproepen (reactance') of machteloosheid, angst, depressiviteit en fatalisme tot gevolg hebben.

Waar een Jichamelijke aandoening op zich al kontroleverlies en afhankelijkheid veroorzaakt, wordt dit door de wijze waarop ziekenhuizen zijn georganiseerd onnodig versterkt. De lichamelike problemen van de patiënt worden vaak op een voor hem onbegrijpelijke wijze geanalyseerd, resulterend in een diagnose en een therapie. De relatie tussen de diagnose, de therapie en de effekten van de therapie is voor de patient valk niet duidelijk. Een patient wordt bij het oplossen van zijn problemen niet of slechts marginaal betrokken. In een extreme situatie wordt bijwoorbeeld over het probleem van de patiënt in diens aanwezigheid gekommuniceerd, zonder dat deze bij het gesprek betrokken wordt. Bovendien wordt de patiënt gekonfronteerd met een snelle opeenvolging van veel kortulurende interakties met veel verschillende professionele hulpverleners. De patiënt heeft daarbij maar weinig zekerheid over, en weinig invloed op, het moment, de duur en de inhoud van deze interakties (zie bijwoorbeeld Waitzkin \& Stoeckle, 1972; McIntosch, 1974; Taylor, 1979; Waitzkin, 1985). Hoewel door de ontwikkeling van de medische diagnostiek en de therapeutische mogelijkheden 
artsen en andere behandelaars voor het vaststellen van de diagnose en de therapie runder aangewezen zjin op het gesprek met de patient, is kommunicatie voor de patient zeker niet minder belangrijk geworden (Innes, 1977). Bij hulpverleners blikt er bovendien een dualisme te bestaan ten aanzien van het informeren van de patient. Enerzjds bevordert het infomeren van de patient dat deze zich aan behandelingswoorschriften houdt en zich meer kobpperatief opstelt, maar anderzijs laten behindelars patienten (bewust) voor een deel in het onzekere, omdat door een zekere "mystiek" het vetrouwen in de behandeling bewaard blijt (Waitzkin \& Stoeckle, 1972; Melntosh, 1974).

De werkdruk onder verpleegkundigen en artsen is over het algemeen groot. Zij hechten mede hieadoor belang aan het kumnen beinvloeden van de duur en de inhoud vari interakties met patienten. Het is niet op te brengen om met een groot aantal patieriten intensief kontakt te hebben en zich jn de situatie van elk van de patiënten in te leven (zie bijwoorbeeld Keirse, 1987; Maslach \& Jackson, 1982). Uit onderzoek blijkt dat het woor veel hulpverleners moeilijk is een evenwicht te vinden tussen afstand en betrokkenheid, waarbij aan de behoeften van een patiënt zo veel mogelijk tegemoet wordt gekomen, maar waarbij de hulpverlener zichzelf ook staande kan houden en er voldoende tijd overblijft voor de behandeling en de lichamelijke verzorging van patienten (Koocher, 1979; Baider \& Porath, 1981; Wortman, 1984). Uit een literaturoverzicht van Lanceley (1985) over de wijze warop verpleegkundigen proberen greep te houden op interakties met patiënten, blijkt bijvoorbeeld dat zij de patient de indruk geven geen tijd te hebben, praten in de 'wij-vorm' ("we denken dat u morgen naar huis kunt", "hoe voelen we ons vandaag?", "we gaan toch niet vervelend doen?") of spreken in de gebiedende wijs ("u moet nu gaan slapen").

Een probleem ten aanzien wan de medische en verpleegkundige voorlichting, is dat deze vaak complex is en een stochastisch karakter draagt, waardoor het moeilijk wordt deze adekwaat buj een patiënt ower te brengen, omdat de waarde van een specifieke uitspraak voor een individuele patiënt beperkt is. Daarnaast blijkt uit socio-linguistisch onderzoek dat patiënt en hulpverlener vaak niet dezelfde "taal' spreken (Waitzkin, 1.985). Ook zijn patiënten vaak gespannen, begrijpen ze de informatie niet of vergeten ze de informatie (Ley, 1979).

Volgens Taylor (1979) bemerken patiënten, onder invloed van onder andere de hiervoorgenoemde faktoren en processen, dat zij weinig invloed hebben op de kommunicatic met hulpverleners en op de inhoud van de verzorging. Omdat zij echter weel waarde hechten aan een voorspoedig herstel en van mening zijn dat vooral de inzet van artsen en verpleegkundigen hierbij van belang is, zullen de meeste patiënten trachten aan hun verwachtingen te voldoen. Zij spreekt van rolgedrag, waarbij rolgedrag beschouwd kan worden als gedrag dat voldoet aan de (normatieve) verwachtingen van rolzenders (artsen/verpleegkundigen), en dat gebaseerd is op een specifieke positie (patient) in een sociaal systeem (vergelijk De Ruiter \& Visser, 1983). Slechts weinig patienten zullen zich hier tegen verzetten "(...) patients adjust to depersonalization by assuming ether 'good patient" or "bad patient' behavior (...). An analysis of the behavioral arributes of these roles, however, will reveal that many 'good patients' are actually in a shate of depressed or anxious helplessness, whereas the 'bad patient' is exhibiting anger against the arbitray exercise of control by the hospital (reactance). We will argue that both helplessness and reactance produce physiological, cognitive, behavioral and affective 
consequences that can strongly interfere with the course of recovery and that helplessness and reactance in patients evoke reactions in hospital staff that also have undesirable consequences for treatment and recovery" (Taylor, 1979, p. 157).

Eerst worden nu enkele onderzoekingen besproken die handelen over de kognitieve, motivationele, affektieve en gedragsmatige gevolgen van invloedsveranderingen in een ziekenhuis of in daarop gelijkende situaties. Vervolgens worden deze fenomenen ingepast in een algemeen theoretisch kader.

\section{Informatie en invloed bij een medisch onderzoek}

In een groot aantal studies is de relatie onderzocht tussen het geven van informatie en/of gedragsinstruktie aan patiënten voor een medische ingreep en de door patiënten ervaren stress tijdens of na de ingreep. Langer, Janis en Wolfer (1975) verstrekken bijwoorbeeld aan patiënten die geopereerd moeten worden, (extra) informatie ower de ingreep of zij geven adviezen en instruktie om aan positieve aspekten van de situatie te denken ('cognitive control'). Met name kognitieve kontrole blijlkt pré- en postoperatieve stress te reduceren. Ook uit andere studies waarin de effekten van (extra) voorlichting en/of gedragsinstruktie in het kader van een medische ingreep worden onderzocht, lijken deze effecten overwegend gunstig (bijvoorbeeld minder stress, minder pijnstillers, lagere hartslag; zie bijvoorbeeld Johnson \& Leventha], 1974; Shipley, Butt, Horwitz \& Farbry, 1978; Mills \& Krantz, 1979; Krantz et al., 1980; voor een overzicht zie Reading, 1979).

\section{Invloed op interacties}

Naast onderzoek naar situaties waarin patiënten invloed wordt gegeven op het verloop van een ingreep, of waarin gedragsinstruktie wordt gegeven waardoor een ingreep minder onaangenaam verloopt, is er onderzoek verricht naar de mate van invloed van personen op interakties. Baum, Aiello \& Calesnick (1978) onderzochten de gevolgen van de beperkte mogelijkheden bij een groep studenten om hun interpersoonlijke kontakten te reguleren. Een deel van de studenten had kamers toegewezen gekregen waarbij het --door de wijze waarop de woonruimtes waren gelokaliseerd-- goed mogelijk was zelf te bepalen of, en zo ja, welke medestudenten men wilde ontmoeten. Een ander deel van de studenten had een kamer gekregen waarbij dit in veel mindere mate mogelijk was. Het blijkt dat naarmate studenten minder mogelijkheden hebben on invloed uit te oefenen op de omgang met medestudenten, zij meer kompetitief gedrag vertomen, zich vaker aan kontakt met anderen onttrekken en symptomen vertonen van hulpeloosheid (voor een overzicht zie Baum \& Valins, 1979).

Schulz (1976) manipuleerde in een veldexperiment de mogelijkheden van bejaarden in een verzorgingstehuis om bezoek te ontvangen van een student. Een groep bejaarden kreeg de mogelijkheid de frekwentie en de duur van het bezoek zelf te bepalen. Een tweede groep werd alleen geïnormeerd over de frekwentie en duur ('zekersheidskonditie'). Een derde groep kreeg zelfs deze informatie niet. Een wierde groep kreeg in het geheel geen (extra-)bezoek. De resultaten wijzen uit dat zowel invloed op de frekwentie en duur van het bezoek, als alleen zekerheid hierover, positieve effekten geeft in termen van het gebruik van minder medicijnen, een betere lichamelijke en psychische gesteldheid en een grotere deelname aan andere sociale activiteiten. Uit een 
vervolgstudie (Schulz \& Hartman Hanusa, 1978) blijkt dat op lange termijn -twee tot drie en een half jaar na beëindiging van het experiment-- de positieve effekten geheel verdwenen zijn. De groepen die bij beëindiging van het experiment de meest positieve effekten vertonen, geven op langere termijn juist blijk van meer negatieve effekten. Rodin \& Langer (1977) vinden in een vergelijkbare studie wel positieve effekten op langere termijn. Schultz en Hartman Hanusa geven aan dat de manipulatie in de studie van Rodin en Langer bestaat uit het geven van een bepaalde verantwoordelijkheid aan bejaarden en het aanmoedigen deze verantwoordelijkheid op zich te nemen, terwijl de invloed in de studie van Schultz tijdelijk van aard was, en de invloed vanwege het interpersooniljke karakter ook een zekere afhankelijkheid met zich meebracht.

\section{Hospitalisatie}

Raps, Peterson, Jonas \& Seligman (1982) hebben onderzoek verricht naar de gevolgen van hospitalisatie. Zij veronderstellen, net zoals Taylor, dat opname in een ziekenhuis gepaard gaat met verlies van invloed (kontrole), dat dit bij patiënten weerstand oproept en dat de patiënt pogingen zal ondernemen deze invloed te herwinnen ("reactance"). Omdat patiënten daar niet in zullen slagen, zullen zij zich er op den duur bij neerleggen. Het blijkt dat naarmate patiënten langer zijn opgenomen, zij minder presteren op kognitieve taken ('problem-solving deficits') en meer blijk geven van depressiviteit. Raps et al. (1982) en Taylor (1979) verklaren hun bevindingen aan de hand van de theorie over aangeleerde hulpeloosheid ('learned helplessness'). Deze theorie werd oorspronkelijk ontwikkeld bij de bestudering van het gedrag van dieren (Seligman \& Maier, 1967) en is nauw gerelateerd aan de sociale leertheorie (zie bijvoorbeeld Rotter, 1966; Zuroff, 1980). Recentelijk heeft deze theorie overigens ook binnen het verpleegkundig onderzoek zijn intrede gedaan (Quinless \& McDermott Nelson, 1988). We zullen de aangeleerde hulpeloosheidstheorie in het kort bespreken, opdat we de hierboven beschreven reakties van patiënten in een ziekenhuis in een theoretisch kader kunnen plaatsen.

\section{Aangeleende hulpeloosheid}

De sociale leertheorie (zie bijwoorbeeld Rotter, 1966; Zuroff, 1980) veronderstelt, dat mensen op grond van ervaringen in het verleden, verwachtingen hebben over de mate waarin bepaalde 'uitkomsten' het gevolg zijn van het eigen gedrag. 'Uitkomsten' worden bimnen de sociale leertheorie beschreven in termen van pasitieve (gewenste) of negatieve (ongewenste) konsekwenties van gedrag (zie bijwoorbeeld Shaw \& Costanzo, 1970, p. 28). Gedrag dat tot specifieke uitkomsten leidt, versterkt de verwachting dat in de toekomst hetzelfde gedrag ook dezelfde uitkomsten tot gevolg zal hebben. Zijn de uitkomsten wenselijk, dan zal men gemotiveerd zijn het gedrag vaker te gaan vertonen. Zijn de uitkomsten onwenselijk, dan zal men minder gemotiveerd raken het gedrag te herhalen. Negatieve en positieve uitkomsten leiden tot respektievelijk verlaging en verhoging van de motivatie om het gedrag te herhalen. De manieren waarop megatieve uitkomsten kunnen leiden tot demotivatie, gedragsdeficiëntie en depressiviteit zijn onderzocht in studies over 'aangeleerde hulpeloosheid' (zie voor een overzicht Garber \& Seligman, 1980)

De aangeleerde hulpeloosheidstheorie stelt dat mensen door eigen ervaringen leren dat ze niet in staat zijn voor hen belangrijke uitkomsten tot stand te brengen. 
Experimenteel onderzoek naar het aangeleerde hulpeloosheidsfenomeen wordt gekenmerkt door de volgende opzet: proefpersonen noeten een voor hen onbekende taak een aantal keren verrichten. $\mathrm{Na}$ elke poging wordt de proefpersoon-gefingeerde en gemanipuleerde-- feedback gegeven over zijn prestatie. De theorie veronderstelt dat indien een persoon, ongeacht zijn werkelijke taakprestatie, keer op keer te horen krijgt dat hij/zij heeft gefaald, de persoon in steeds mindere mate zal verwachten dat hij/zij in staat zal zijn de taek in de toekomst succesvol te verrichten. Na verloop van tijd zin deze verwachtingen zo sterk afgenomen dat de persoon de taakuitkomst als onafhankelijk (non-kontingent) gaat zien van zijn eigen gedrag. De persoon zal daardoor steeds minder gemotiveerd zijn zich opnieww voor eenzelfde taak in te spannen ("wat ik ook doe, het lukt toch niet"). Op deze wijze vindt op grond van de effekten van het eigen gedrag een voortdurende bijsteling plaats van verwachtingen (kognities), hetgeen invloed heeft op de motivatie van de persoon en daamee op het gedrag.

Aangeleercie hulpeloosheid kan gezien worden als een gedragsdeficientic ten gevolge van blootstelling aan non-kontingente vitkomsten. Anders gezegd: hulpeloosheid is het gewolg van het herhaaldelijk blootstaan aan non-kontingente en ongewenste uitkomsten, waardoor deze toegeschreven worden aan onkontroleerbare faktoren, hetgeen de verwachtingen over de relatie tussen toekomstig gedrag en gewenste uitkomsten minimaliseert, waardoor de inspanningen afnemen en men zich passief opstelt.

\section{Aangeleerde hulpeloosheid: enkele uitwerkingen.}

In het bovenstaande is beschreven hoe patiënten kunnen reageren op een ziekenhuisopname, en zijn deze reacties in een theoretisch kader geplaatsi. AJvorens voorspeld kan worden in welke mate Integrerende Verpleegkunde deze reacties zal beinvloeden, zullen enkele onderdelen nader moeten worden besproken.

In het voorgaande wordt de indruk gewekt dat situaties waarin men non-kontingentie ervaart, hoe dan ook leiden tat een situatie van aangeleerde hulpeloosheid. Het blijkt echter dat individuen sterk verschillen in de mate warin het ervaren van nonkontingentie tot hulpeloosheid leidt. Ingegaan wordt op een persoonskenmerk dat kan verklaren waarom individuen verschillend reageren. In de tweede plaats is het noodzakelijk voor het ontstaan van hulpeloosheid, dat de persoon de 'uitkomst' belangrijk vindt. Daarnaast is van belang dat de 'uitkomst' als onwenselijk ervaren wordt. We zullen kort op deze drie onderwerpen ingaan.

De mate warin een individu verwacht bepalde uitkomsten te kunnen realiseren, kan van onderwerp tot onderwerp verschillen. Temand die bijvoorbeeld in staat is adekwaat leiding te geven aam een bedrijf, is wellicht in andere sociale situaties (bijwoorbeeld het aangaan wan intieme relaties) of op andere terreinen (bijwoorbeeld de eigen gezondheid) minder of niet in staat door het eigen gedrag 'uitkomsten' te beinwloeden. Wel is gebleken dat mensen verwachtingen en leerervaringen op het ene terrein in zekere mate generaliseren naar andere velden (zie voor een overzicht, Zuroff, 1980). De verwachting van de persoon ten aanzien van de eigen invloed op een taak A, voorspelt minder zijn verwachtingen ten aanzien van taak $B$ naarmate taak $B$ minder lijkt op taak A. Wanneer een patiënt door ervaring heeft geleerd dat in een ziekenhuis alleen een gelaten en passiewe houding wordt beloond, moet niet uitgesloten worden dat een patiënt deze ervaring generaliseert naar gerelateerde dimensies. "Als 
ik geen invloed heb op de behandeling en verzorging, kan ik ook het werloop van de ziekte nuet beimwloeden .... en kan ik dus gerust blijven roken".

Rotter (1966) spreekt in zijn sociale lewrtheorie over de gegeneraliseerde verwachting als 'locus of control. Het betreft ex bipolaire persoonlijkheidsdimensie met een interne beheersingspool (internal') en een externe beheersingspool ('external'). "Intermals" zien in tegenstelling tot 'externals' uitkomsten als afhankelijk van het eigen gedrag. Mensen met hoge verwachtingen over de mate waarin uitkomsten gerelateerd zijn aan het eigen gedrag (internals), spannen zich meer en langer in dan mensen met lage verwachtingen en hebben daardoor meer kans dat zij uitkomsten in de gewenste richting kunnen bewnloeden. Verwachtingen over beheersing dragen daarmee deels een 'self-fulfilling prophecy"-karakter (Newman, 1978; Pittman \& Pittman, 1979).

Mensen met een hoge interne beheersing (internals") reageren anders op nonkontingentie dan mensen met een hoge externe beheersing ('externals") (zie bijvoorbeeld Wortman \& Brehm, 1975; Diener \& Dweck, 1978; Pittman \& Pittmany 1979). Voorts blijkt dat mensen met hoge initièle verwachtingen, hun verwachtingen op grond van en enkele negatieve erwaring niet direkt bijstellen. Naarmate de oorspronkelijke verwachting hoger is, zal men langer op non-kontingentie reageren door extra inspanning, waarbij een grotere diversiteit aan strategieën wordt benut (Zuroff, 1980; Parkes, 1984). Blijkt echter dat deze inspanningen een ongewenst resultaat bljuven opleweren, dam zullen verwachtingen grondig worden bijgesteld. 'Internals' leggen zich minder snel neer bij kontroleverlies, maar blijkt "niets te helpen", dan zijn de emotionele gevolgen wel groter dan bij 'externals' (Burger \& Arkin, 1980; Pittman \& Pittman, 1979).

Ook de mate warin een persoon de dimensie(s) waarop invloedsverlies optreedt belangrijk vindt, is relevant ('reinforcement value'; Roth, 1980; Zuroff, 1980). Naarmate mensen bepaalde uitkomsten belangrijker vinden, zullen de reakties op het verlies van invloed sterker zijn. Dimensies betreffende de eigen gezondheid blijken in het algemeen belangrijk gewonden te worden. Hoewel het uiteindelijke resultaat van non-kontingentie (een volledige inhibitie van probleemoplossend gedrag) niet afhankelijk lijkt van de faktor 'belangrijkheid', zijn de emotionele gevolgen dit zeer zeker wel. Iemand die bemerkt dat hij/zij een voor hem/haar onbelangrijke taak niet met succes kan voltooien, zal zich hier snel bij neerleggen. Dit zal geen sterke affektieve reaktie veroorzaken. Gekonfronteerd worden met een fatale ziekte en moeten accepteren dat men zelf geen invloed kan witodenen op het ziekteverloop, kan echter sterke emotionele reakties veroorzaken.

\section{Vertrouwen in artsen en verpleegkundigen: konformiteit}

Wanneer patienten bij opname in een ziekenhuis verwachten dat artsen en verpleegkundigen zorg zullen dragen voor belangrijke gewenste uitkomsten (bijvoorbeeld een voorspoedig herstel), zullen zij in geringe mate reageren op verlies van imloed. Het blijkt dat het beschreven leerproces dat resulteert in hulpeloosheid, niet optreedt bij gewenste non-kontingente uitkomsten (zie Koller \& Kaplan, 1978; Zuroff, 1980; Miller III \& Norman, 1979). Wallston en Wallston (1982) beschrijven de verwachting var patienten over de mate warin 'powerful others' relevante uitkomsten kumen realiseren. 'De externe beheersing', zoals beschreven door Rotter (1966), wordt door then (in de kontext van gezondheid) opgesplitst in 'Powerful others Locus of 
Control' en "Chance Locus of Control'. Aan de hand van dit onderscheid kumnen werwachtingen van een persoon opgesplitst worden wat betreft de mate waarin de persoon van mening is, dat hij of zij 'zelf, "anderen" of 'niemand" uitkomsten kan beïnwloeden. Patiënten die verwachten dat artsen en verpleegkundigen voor gewenste uitkomsten zullen zorgen, en die voorts van mening zijn dat zij daar zelf weinig aan kunnen bijdragen, zullen zich sterk aan de rolverwachtingen konformeren (zie bijvoorbeeld Jones \& Gerard, 1967, p. 401-404). Deze opvatting wordt ook naar voren gebracht door Baltes \& Skinner (1983). Zij bekritiseren de wijze waarop. Raps et al. (1982) hun onderzoeksbevindingen (zie p. 16) interpreteren in termen wan 'aangeleerde hulpeloosheid'. Baltes en Skinner stellen dat volgens de aangeleerde hulpeloosheidstheorie non-kontingentie een voorwaarde is voor gedragsinhibitie, en dat non-kontingentie in de genoemde studie niet is aangetoond. $\mathrm{Zij}$ geven een tweetal alternatieve verklaringen, namelijk

- vanuit de sociale leertheorie: een ziekenhuisomgeving wordt niet gekenmerkt door non-kontingentie. Een patiënt leert er nieuwe kontingenties. Hij of zij leert. dat een passieve en afhankelijke houding wordt beloond en een aktieve houding of gedrag gericht op vergroting van de invloed bestraft. Passiviteit is daarmee instrumenteel. Zo gezien is passiviteit een adekwate strategie.

- vanuit de roltheorie: verwachtingen van omstanders (hulpverleners, familie) over gedrag gebaseerd op regels en normen in een specifieke setting, sturen het gedrag van patiënten. Van patiënten wordt verwacht dat ze hulpeloos en passief zijn. Naarmate men langer in een specifieke setting verkeert, zal men zich meer aan zulke sociale standaarden konformeren.

Peterson \& Raps (1984) hebben op deze kritiek gereageerd door te stellen, dat deze alternatieven de passieve houding van de patiënten wel verklaren, maar niet de toename van depressiviteit.

\section{Verwachingen}

We veronderstellen dat mensen uitkomsten betreffende hun behandeling en verzorging in een ziekenhuis belangrijk vinden. Wanneer we seen situatie zonder Integrerende Verpleegkunde (taakgericht verplegen) beschouwen als een situatie waarin de patiënt weinig de gelegenheid krijgt om invloed uit te oefenen op het ziekenhuisverblijf, en een situatie met Integrerende Verpleegkunde als een situatie waarin een patiênt hiertoe relatief veel gelegenheid krijgt, dan zullen patiënten onder lintegrerende Verpleegkunde meer kontingentie gaan ervaren (bijwoorbeeld: "er wordt rekening gehouden met mijn mening"). Dit zal hun verwachtingen over hun invloed op het verblijf vergroten, waardoor gedrag gericht op beînvloeding van het verblijf zal toenemen (bijvoorbeeld informatie vragen, eigen mening geven). Hierdoor zal de patiënt onder meer beter op de hoogte raken van ziekte en behandeling. Tevens zullen patiënten deze verwachtingen enigermate generaliseren naar verwachtingen over gerelateerde onderwerpen (bijwoorbeeld de eigen gezondheid). Dit zal gedrag op deze dimensies bevorderen (bijwoorbeeld zelfzorg). Naarmate de opnameduur langer is, zullen deze effekten in sterkere mate optreden.

'Zelfzorg' wordt in de verpleegkundige literatuur uitgewerkt door Orem (1985; zie ook Brouns, 1988). Zij defimieert zelfzorg ais: "the practice of activities that individuals initiate and perform on their own behalf in maintaining life, health, and well-being" (p. 
35). Zelfzorg refereert in deze definitie aan gedrag. Centraal in haar 'zelfzorgmodel' stat het vermogen (ability) van een individu om zelfzorg te verrichten. Een situatie vereist bepaald zelfzorggedrag om een specifieke behoefte te bevredigen op het terrein van de gezondheid. Indien er een discrepantie bestaat tussen het vereiste zelfzorggedrag en het vermogen dit zelfzorggedrag te vertonen, ontstaat er een zelfzorgtekort. De verpleegkunde richt zich volgens Orem dan ook op zelfzorg deficiëntie. Deze deficiëntie kan gekompenseerd of verminderd worden doordat de verpleegkundige aktiviteiten van een patiënt overneemt, of doordat door edukatie en training het vermogen van de patiënt tot zelfzorg wordt vergroot. Naast het vermogen bepaalde aktiviteiten te verrichten, kunnen ook andere determinanten van (zelfzorg)gedrag onderscheiden worden, zoals motieven, verwachtingen en opvattingen van de patiënt of zelfs opvattingen en houdingen van relevante omstanders (zie bijvoorbeeld Fishbein \& Ajzen, 1975). Een patiënt kan bijvoorbeeld wel het vermogen hebben om vereist zelfzorggedrag te verrichten, maar niet gemotiveerd zijn dit gedrag te vertonen, omdat hij of zij (ten onrechte) verwacht dat dit gedrag niet doelmatig zal zijn. Gelet op het voorgaande, zal Integrerende Verpleegkunde zich van het funktionele verplegen eerder onderscheiden, doordat patiënten meer kontingentie ervaren en daardoor meer gemotiveerd zullen zijn (zelfzorg)gedrag te vertonen, dan dat Integrerende Verpleegkunde meer het zelfzorgvermogen van patiënten vergroot.

We kumnen verwachten dat patiënten met hoge initiele verwachtingen over de eigen invloed op de behandeling, de verzorging en gerelateerde dimensies, op (non-)kontingentie reageren volgens het aangeleerde hulpeloosheidsparadigma. Patiënten die verwachten dat vooral artsen en verpleegkundigen (en niet zij zelf) relevante uitkomsten bepalen, zullen met name reageren volgens de roltheorie en konformiteitstheorie. Zij zullen onder Integrerende Verpleegkunde mogelijk ook meer initiatief nemen en zelfzorgaktiviteiten verrichten. Dit niet omdat zij het van belang vinden invloed te hebben op het verblijf, maar omdat zij aan (rol)verwachtingen (van verpleegkundigen) willen woldoen. Patiënten met hoge initiële verwachtingen zullen in een situatie met weinig invloed (funktioneel verplegen) op den duur een passieve houding aannemen. Zij zullen dit echter niet doen omdat hulpverleners deze houding wenselijk vinden, maar omdat zij bij herhaling non-kontingentie ervaren hebben en zich hierbij noodgedwongen neerleggen. In een situatie met Integrerende Verpleegkunde, zullen zowel patiënten die verwachter dat zij zelf invloed kunnen uitoefenen, als patiẻnten die verwachten dat artsen en verpleegkundigen het verblijf kunnen beinvloeden, zich --weliswaar om verschillende redenen-- aktief opstellen. In een situatie zonder Integrerende Verpleegkunde zullen patiënten zich ongeacht hun verwachtingen (op den duur) passief opstellen. Het nivo van de initiële verwachtingen van patiënten over de eigen invloed in het ziekenhuis lijkt daarmee niet gerelateerd aan het gedrag van pattiënten. Wat de affektieve gevolgen betreft kan wel cen verschil verwacht worden. Volgens de roltheorie zal iemand met name stress ervaren wanneer hij niet in staat is het rolgedrag te vertonen of wanneer diverse relevante kategorieën omstanders er tegenstrijdige verwachtingen op na houden. Volgens de aangeleerde hulpeloosheidstheorie zal iemand met name stress ervaren wanneer er een grote discrepantie bestaat tussen verwachte en feitelijke kontingentie (patiënten met hoge verwachtingen over de eigen invloed op het ziekenhuisverblijf in een situatie met taakgericht verplegen). 


\section{Hypothesien}

Alvorens de hypothesen te formuleren worden in het onderstaande schema (Figuur 2-1) de belangrijkste begrippen en hun veronderstelde onderlinge relaties weergegeven. In hoofdstuk 5 wordt de wijze besproken waarop deze begrippen zijn geoperationaliseerd.

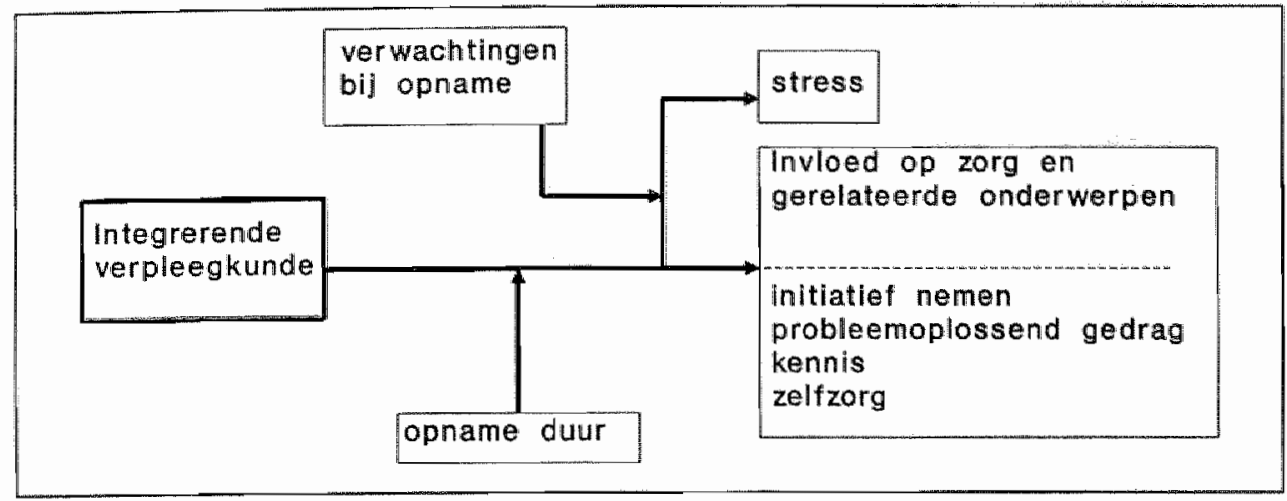

Figun 2-1. Overzicht van de besproken begrippen en hun veronderstelde onderlinge relaties

1. Patiênten die verpleegd worden op verpleegeenheden waar het model Integrerende Verpleegkunde is ingevoerd, zullen meer invloed ervaren op de eigen verzorging en het ziekenhuisverblijf dan patiënten die verpleegd worden op verpleegeenheden waar dit model niet is ingevoerd (kontrole-verpleegeenheden).

2. Patiënten die verpleegd worden op verpleegeenheden met Integrerende Verpleegkunde, zullen hogere verwachtingen krijgen over de eigen invloed op gerelateerde dimensies (gezondheid, herstel) dan patiënten die verpleegd worden op kontroleverpleegeenheden.

3. Patiënten die verpleegd worden op verpleegeenheden met Integrerende Verpleegkunde, zullen

a) meer initiatieven nemen,

b) blijk geven van meer probleemoplossend gedrag,

c) beter geinformeend zijn over ziekte en behandeling, en

d) meer zelfzorgaktiviteiten verrichten dan patiënten die verpleegd worden op kontrole-verpleegeenheden.

4. Naarmate de opnameduur langer is, zullen de effekten zoals beschreven onder $1 \mathrm{t} / \mathrm{m}$ 3 sterker zijn.

5. Naarmate patiënten hogere initiële verwachtingen hebben over hun invloed op de verzorging, zullen zij op verpleegeenheden met Integrerende Verpleegkunde minder stress ervaren en op kontrole-verpleegeenheden meer stress. 



\section{HOOFDSTUK 3 DE POSITIE VAN VERPLEEGKUNDIGEN IN DE ORGANISATIE}

In dit hoofdstuk zullen, op grond van de in het eerste hoofdstuk geformuleerde verwachtingen, de mogelijke gevolgen van Integrerende Verpleegkunde voor de verpleegkundige discipline nader worden besproken. Eerst wordt nagegaan onder welke omstandigheden verpleegkundigen in staat zijm door Integrerende Verpleegkunde hun invloedspositie in de organisatie te versterken. Naar aanleiding hiervan zullen enkele hypothesen worden geformuleerd. Daarna wordt ingegaan op de mogelijke gevolgen van deze invloedsvergroting voor anderen. We richten ons daarbij vooral op de positie van artsen en op de positie van de verpleegkundige leiding. In dit eerste deel wordt gebruik gemaakt van enkele --veelal aan elkaar verwante-- theorieën en theoretische inzichten. Het gaat daarbij om de "Expectation States Theory" (Berger, Conner \& Fisek, 1974), de theoretische verhandelingen over 'macht' van Veen (1983) en de studies vam Tannenbaum (1966) over de gevolgen van participatie binnen organisaties. In het laatste gedeelte van dit hoofdstuk wordt aandacht besteed aan de mogelijkheid dat Integrerende Verpleegkunde, doordat nieuwe taken uitgevoerd moeten worden, onzekerheid bij individuele verpleegkundigen veroorzaakt. Hierbij wordt gebruik gemaakt van de sociale vergelijkingstheorie (Festinger, 1954; Suls \& Miller, 1977). Daarbij wordt ingegaan op enkele kondities die van invloed zijn op de mate waarin verpleegkundigen onzekerheid ervaren.

\subsection{De invloed van verpleegkundigen}

In paragraaf 1.3 werd de verwachting toegelicht dat vanwege de koördinerende rol van verpleegkundigen in de patiëntenzorg de verpleegkundige door Integrerende Verpleegkunde meer invloed zal krijgen op de patiëntenzorg en de organisatie van de werkzaamheden op de verpleegeenheid. Hoewel hier met het begrip 'invloed' niets anders wordt bedoeld dan bij de geformuleerde verwachtingen over de effekten van Integrerende Verpleegkunde voor patiënten, zijn de posities van de verpleegkundigen en die van patiènten in een ziekenhuisorganisatie nogal verschillend. De sociale leertheorie, die in het voorgaande hoofdstuk werd gebruikt om de positie van patienten binnen een ziekenhuis te schetsen, leent zich minder voor het verschaffen van inzicht in de betekenis van de invloed van groeperingen die onderdeel zijn van een organisatie. Verpleegkundigen vormen als professionele beroepsgroep een struktureel onderdeel van de organisatie. Patiënten zijn niet als groep georganiseerd, vormen geen onderdeel van de organisatie, en de populatie patiënten wisselt frekwent van samenstelling. Ten aanzien van de patiënt heeft 'irvvloed' vooral betrekking op het vergroten van de betrokkenheid bij de verzorging en de behandeling. Dit met de bedoeling dat de patiẻnt leert dat het oplossen van zijn of haar gezondheidsprobleem niet uitsluitend een zaak is van artsen en verpleegkundigen, maar dat de patiënt zelf hier naar vermogen aen bijgrage aan kan en moet leveren. Invloed heeft daarbij slechts in beperkte mate 



\section{HOOFDSTUK 3 DE POSITIE VAN VERPLEEGKUNDIGEN IN DE ORGANISATIE}

In dit hoofdstuk zullen, op grond van de in het eerste hoofdstuk geformuleerde verwachtingen, de mogelijke gevolgen van Integrerende Verpleegkunde voor de verpleegkundige discipline nader worden besproken. Eerst wordt nagegaan onder welke omstandigheden verpleegkundigen in staat zijn door Integrerende Verpleegkunde hun invloedspositie in de organisatie te versterken. Naar aanleiding hiervan zullen enkele hypothesen worden geformuleerd. Daarna wordt ingegaan op de mogelijke gevolgen van deze invloedsvergroting woor anderen. We richten ons daarbij vooral op de positie van artsen en op de positie van de verpleegkundige leiding. In dit eerste deel wordt gebruik gemaakt van enkele --weelal aan elkaar verwante-- theorieën en theoretische inzichten. Het gaat daarbij om de "Expectation States Theory" (Berger, Conner \& Fisek, 1974), de theoretische werhandelingen over 'macht' van Veen (1983) en de studies van Tannenbaum (1966) over de gevolgen van participatie binnen organisaties. In het laatste gedeelte van dit hoofdstuk wordt aandacht besteed aan de mogelijkheid dat Integrerende Verpleegkunde, doordat nieuwe taken uitgevoerd moeten worden, onzekerheid bij individuele verpleegkundigen veroorzaakt. Hierbij wordt gebruik gemaakt van de sociale vergelijkingstheorie (Festinger, 1954; Suls \& Miller, 1977). Daarbij wordt ingegaan op enkele kondities die van invloed zijn op de mate waarin verpleegkundigen onzekerheid ervaren.

\subsection{De invloed van verpleegkundigen}

In paragraaf 1.3 werd de verwachting toegelicht dat vanwege de koördinerende rol van verpleegkundigen in de patiëntenzorg de verpleegkundige door Integrerende Verpleegkunde meer invloed zal krijgen op de patiëntenzorg en de organisatie van de werkzaamheden op de verpleegeenheid. Hoewel hier met het begrip "invloed" niets anders wordt bedoeld dan bij de geformuleerde verwachtingen over de effekten van Integrerende Verpleegkunde voor patiënten, zijn de posities van de verpleegkundigen en die van patiënten in een ziekenhuisorganisatie nogal verschillend. De sociale leertheorie, die in het voorgaande hoofdstuk werd gebruikt om de positie van patienten binnen een ziekenhuis te schetsen, leent zich minder voor het verschaffen van inzicht in de betekenis van de invloed van groeperingen die onderdeel zijn van een organisatie. Verpleegkundigen vormen als professionele beroepsgroep een struktureel ondercleel van de organisatie. Patiènten zijn niet als groep georganiseerd, wormen geen onderdeel van de organisatie, en de populatie patiënten wisselt frekwent van samenstelling. Ten aanzien van de patiënt heeft 'invloed' vooral betrekking op het vergroten van de betrokkenheid bij de verzorging en de behandeling. Dit met de bedoeling dat de patiënt leert dat het oplossen van zijn of haar gezondheidsprobleem niet uitsluitend een zaak is van artsen en verpleegkundigen, maar dat de patiënt zelf hier naar vermogen een bijdrage aan kan en moet leveren. Invloed heeft daarbij slechts in beperkte mate 
betrekking op sociale of interpersoonlijke invloed. Invloedsweranderingen hebben bij de verpleegkundige discipline daarentegen een meer sociaal karakter. Het gaat om invloed op het beleid van de verpleegeenheid en op de patiëntenzorg door de toename van koördinerende taken als grevolg van patienttoewijzing. De taken betreffen bijvoorbeeld het afstemmen van de verschillende deeltaken rondom een patiënt, de planning van deze aktiviteiten en de koürdinatie van de aktiviteiten tussen verschillende disciplines betreffende eên en dezelfde patiënt. Gelet op het voorgaande wordt het begrip invloed zoals in de huidige context gebruikt, niet uitgewerkt aan de hand van de sociale leertheorie, maar met behulp van inzichten uit de organisatiekunde.

Het concept 'invloed' staat centraal in diverse sociaal-wetenschappelijke theorieën. Veen definieert in zijn machtstheorie de invloed van persoon $O$ op persoon $P$ bijwoorbeeld als "de gemobiliseerde macht (kracht), waarmee door O een effekt bereikt kan worden in de opvattingen en/of gevoelens en/of het gedrag van $P^{* 1}$ (Veen, 1982, p. 129). De mate waarin de beïnwloeding het beoogde effect bewerkstelligt, wordt "kontrole" genoemd (zie Veen, 1982; Emans, 1988). Tannenbaum stelt vanuit de organisatiekunde en de participatietheorie 'kontrole' gelijk aan 'invloed' en definieert kontrole als "any process through which a person or group of persons determines (i.e., intentionally affects) what another person or group of persons will do" (Tannenbaum, 1966, p. 84). Thibaut en Kelley (1959) onderscheiden naast 'behavior control' ook 'fate control', waarbij niet het gedrag wan anderen effektief wordt beïnvloed, maar hun uitkomsten. De voorgaande opvattingen hebben gemeen dat zij invloed definiëren in termen van interpersoonlijk gedrag. Dit gedrag is gericht op het beïnvloeden van opvattingen, gedragingen of uitkomsten van een ander.

Veen (1982, 1983) heeft het onderwerp 'invloedswerandering in groepen en organisaties' aan de hand van een aantal begrippen in een theoretisch kader geplaatst. Een centraal begrip in dit kader is macht. 'Macht' verwijst naar de mogelijkheid om invloed wit te oefenen.

\section{Het ontstaan van machisverhoudingen}

Veen gaat met name in op de wijze waarop in nieuwe taakgroepen verschillen in macht tussen (kategorieën van) personen ontstaan. Hij doet dit aan de hand van de 'Expectation States Theory' (Berger et al., 1974; Berger, Fisek \& Norman, 1977; Berger, Rosenholtz \& Zelditch, 1980). Berger et al. (1980) definiëren de processen -.'Status organizing processes'-- die aan het ontstaan van machtsverschillen ten grondslag liggen, als processen waarin onderdelen van, en denkbeelden over karakteristieken van actoren de grondslag vormen van waarneembare ongelijkheden tijdens interakties. Ongelijkheid kan daarbij ontstaan op vier terreinen (zie Veen, 1985, p.74), namelijk:

a. de handelingsruimte: de mogelijkheden die de groepsleden aan een groepslid geven om een bepaalde taakbijdrage te leveren (participatiemogelijkheden)

$b$. de taakbijdrage: de participatiegraad die aangeeft welk deel van de groepstaak door een groepslid wordt verwuld

c. de evaluatie: het oordeel van de groepsleden over de kwaliteit van de taakvervulling van een groepslid

d. de invloed: de mate walarin een groepslid invloed heeft op beslissingen die in de groep ten aanzien van taken worden genomen. 
Deze vier elementen dragen bij aran wat Veer de machts-en prestige-ordening noemt. De vier elementen beïvloeden elkaar bimnen een cyclisch proces. Door meer handelingsruimte neemt de kans op een grotere takbijdrage toe en daarmee de lkams op meer waardering. Een positieve evaluatie geeft meer invloed en dit betekent dat men meer handelingsruimte zal kriggen, of zich kan permitteren meer ruinte te nemen. Integrerende Verpleegkunde zal dit proces net name beïnvloeden doordat de taakinhoud en de taakbijdrage van verpleegkundigen in de patiëntenzorg verandert. We komen bier later in dit hoofdstuk op terug.

De machtsordening en de veranderingen daarin komen, met name binnen hieuwe taakgroepen, volgens de 'Expectation States Theory' voort uit de verwachtingen ("expectation states") die in een groep bestaan ten aanzien van de mate waarin elk van de groepsleden een bijdrage zal kunnen leveren aan het succesvol woltooien vas de groepstaak (bijvoorbeeld de patiëntenzorg). Deze verwachtingen worden op hun beurt weer bepaald door hetgeen Berger et al. (1980) statuskarakteristieken noemen. Een statuskarakteristiek wordt gezien als een kenmerk dat tenminste op twee niveaus kan voorkomen, welke in verschillende mate worden geassocieerd met verwachtingen omtrent de taakbijdrage. Onderscheid wordt daarbij gemaakt in specifieke en diffuse statuskarakteristieken. Specifieke statuskarakteristieken zijn gerelateerd aan verwachtinw gen over de bijdrage aan een specifieke taak. Wanneer een verpleegkundige tijdens een sollicitatiegesprek aangeeft dat zij] een aantal jaren heeft meegewerkt aan een onderzoek naar infuussystemen (specifiek), zal verwacht worden dat zij op dit terrein deskundig en vaardig is, en dat zij een grote bijdrage kan leveren aan specifieke taken betreffende infuussystemen. Diffuse statuskarakteristieken worden geassocieerd met verwachtingen over de bijdrage aan taken in het algemeen. Naarmate verpleegkundigen meer erwaring hebben wordt verwacht dat ze niet alleen veel specifieke verpleegtechnische verrichtingen kunnen uitwoeren, maar ook over het geheel een relatief grote bijdrage kunnen leveren aan de patiëntenzorg op de verpleegafdeling. Specifieke statuskarakteristieken zijn bijwoorbeeld 'bewezen bekwaamheid in de begeleiding van patiënten', 'aangetoonde kwaliteiten in het opstellen van verpleegkundige dossiers', enz. In die zin kan een positief gewaardeerde taakbijdrage in het verleden gezien worden als een specifieke statuskarakteristiek. Diffuse statuskarakteristieken zijn bijvoorbeeld 'de funktie;, "de sexe", "de leeftijd", "het aantal jaren erwaring'(senioriteit), 'fysieke aantrekkelijkheid' en 'genoten opleiding'. In deze studie wordt met name aandacht besteed aan 'het opleidingsnivo' en 'de senioriteit' als diffuse statuskarakteristieken.

\section{Veranderen van machsverhoudingen}

Waar hierboven het ontstaan van machtsverhoudingen ter sprake is gebracht, wordt nu op het veranderen van deze werhoudingen ingegaan.

De 'Expectation States Theory' veronderstelt dat het niet eenwoudig is een machtsen prestige-ordening te veranderen. Meer macht en prestige verwerft men door het verkrijgen van een ander nivo op één of meer relevante statuskarakteristisken. Ten aanzien wan sommige karakteristieken is dit mogelijk (b v waardigheid, opleiding). Ten aanzien van andere karakteristieken --veelal diffuse status karakteristieken-- is dit echter veel moeilijker zo niet ommogelijk (professie, sexe). Het verkrijgen wan meer macht is ook om de volgende reden niet eenvoudig. De ordening beinvloedt niet alleen toekomstige taak-relevante interakties, maar ook de wijze warop die worden 
wargenomen. De ordening is verder redelijk stablel doordat zij niet alleen de warneming maar ook het gedrag van groepsleden dusdanig stuurt dat de ordening bevestigd wordt. Een verpleegkundige die bijvoorbeeld veel aanzien heeft, zal meer de gelegenheid krigen van de andere groepsleden om zichzelf waar te maken, waardoor de kans groot is dat de takkbijdrage van deze verpleegkundige relatief groot is en het aanzien daardoor blift gehandhaafd. Uit het voorgaande blijkt dat de verwachingen vari leden van de organisatie over de taakbjudrage van jemand, een belangrike rol spelen by de mogelijkheden die een persoon krijgt om werkzamheden uit te voeren en invloed op de groepstaken uit te oefenen. Uit de cognitieve psychologie is bekend dat verwachtingen het informatiewerwerkingsproces wan mensen zodanig beinvloeden door bijwoorbeeld selektieve aandacht, waarneming en herinnering, dat deze verwachtingen worden bevestigd (zie bijwoorbeeld Eiser, 1986; Molleman en Van Knippenberg, 1988).

Op grond van de "Expectation States "Theory" kan verwacht worden, dat de mogelijkheden voor verpleegkundigen om hun machtspositie te versterken beperkt zijn (Veen, 1985, p. 76). Zowel op grond van specifieke als diffuse statuskarakteristieken, mag aangenomen worden dat bijwoorbeeld artsen en hoofdverpleegkundigen over het algemeen meer aanzien hebben dan verpleegkundigen. Artsen zijn bijvoorbeeld gemiddeld ouder, hebben meer opleiding genoten en onder hen bevinden zich gemiddeld meer mannen. Ook wordt hun taakbijdrage als belangrijker gezien en zijn de taken van verpleegkundigen veel sterker afgeleid van de werkzaamheden wan artsen dan omgekeerd ("verlengde arm"). Wanneer Integrerende Verpleegkunde gericht is op het verhogen van de status van de verpleegkundige en veranderingen beoogt in de machts- en prestige-ordening, kan verwacht worden dat anderen --die een hogere statuspositie hebben-- hier in principe niet positief tegenover zullen staan (vergelijk, Bowers, 1989). Dit wil niet zeggen dat Integrerende Verpleegkunde geen enkele kans van slagen heeft. In het experiment dat in dit proefschrift wordt beschreven, is met name getracht door het vergroten van de handelingsruimte, de machtspositie van verpleegkumdigen te versterken.

\section{Handelingsruimte}

Zoals eerder gesteld impliceert Integrerende Verpleegkunde een verruiming van taken voor verpleegkundigen. Willen verpleegkundigen in de praktijk deze nieuwe werkzamheden kunnen uitwoeren, dan betekent dit onder andere, dat voor en door verpleegkundigen de nodige ruimte gecreeerd moet worden. Ruimte die voor een deel van anderen (en warschijnlijk met name van de verpleegkundige leiding) afkomstig zal zijn. De organisatie, de verpleegkundige leiding en andere disciplines moeten de verpleegkundigen de gelegenheid geven om de nieuwe werkzaamheden wit te voeren, on zich de nieuwe werkzaamheden eigen te maken en om te laten zien dat deze veranderingen tot wenselijke uitkomsten leiden. Degenen die ruimte geven, moeten het vertrouwen hebben det alles temminste even goed blijft lopen als voorheen. Degene die nieuwe taken krijgt, moet het vertrouwen hebben dat hij/zij de nieuwe taken aankan en kan warmaken.

Extra handelingsrumte is in het kader van de introduktie van Integrerende Verpleegkunde onder andere als wolgt gecreëerd. De direktie van het Academisch Ziekenhuis gat toestemming woor een experiment en in overleg met de verpleegkundige 
Jeiding zijn een aantal verpleegafdelingen geselekteerd warr het experiment zou moeten plaatsvinden. Andere disciplines werden geinformeerd met de bedoeling hen van de wenselijkheid van Integrerende Verpleegkunde te overtuigen. Hen werd gevraagd het experiment te steunen of in ieder geval het voordeel van de twijfel te geven. Met hen werd overeengekomen dat het experimentele karakter van het projekt, impliceert dat Integrerende Verpleegkunde niet vanzelfsprekend definitief en struktureel zal worden ingevoerd, maar dat dit mede afhangt van de mate warin de veronderstelde opbrengsten waargemaakt worden. Met andere woorden, ook wanneer er vooraf overeenstemming bestaat over de wenselijkheid van de veranderingen, is het noodzakelijk, wil men meer invloed krijgen en behouden, dat de veranderingen in de praktijk na verloop van tijd ook daadwerkelijk tot verbeteringen leiden en positief worden geëvalueerd door de verpleegkundigen zelf, maar ook door de verpleegkundige leiding, andere disciplines (en met name artsen) en het ziekenhuismanagement.

\section{Aanvullende begrippen}

Er worden in de literatuur een aantal kondities genoemd, die het proces van het krijgen en behouden van invloed kumnen bevorderen. Veen (1985) geeft bijvoorbeeld aan dat wanneer de reeds bestaande en (door artsen en leidinggevenden) belangrijk gevonden taken ook onder Integrerende Verpleegkunde goed of nog beter uitgevoerd worden en artsen en leidinggevenden bijvoorbeeld merken, dat door meer aandacht voor de niet somatische zorg en het stimuleren van zelfzorg patiënten sneller herstellen en meer tevreden zijn, verpleegkundigen door dit soort succes wel degelijk hun positie kunnen versterken. De inhoud van het hiervoor genoemde begrip "positieve evaluatie", als onderdeel van de machts- en prestige-ordening, vertoont grote overeenkomst met het begrip 'succes' zoals door Veen omschreven.

Een andere door Veen (1983) genoemde faktor die wan invloed is op de machts- en prestige-ordening is de mate waarin verpleegkundigen zich groepsgericht opstellen. Ridgeway (1978) laat zien dat het met name voor de minder-machtigen van belang is zich groepsgericht te gedragen. Dit wil zeggen dat verpleegkundigen eigen succes in het openbaar niet te veel aan zichzelf moeten toeschrijven maar aan de groep als geheel. Wanneer patiënten van een grote tevredenheid blijk geven, doet men er als mindermachtige verstandig aan dit niet alleen toe te schrijven aan de eigen inzet maar bijvoorbeeld ook aan de goede sfeer op de verpleegafdeling en de goede samenwerking met artsen. Integrerende Verpleegkunde kan beter verkocht worden in termen van het algemeen belang --bijvoorbeeld een betere patièntenzorg-- dan in termen van het eigen belang.

Veen (1985) merkt verder op dat het ook van belang is hoe verpleegkundigen zich tijdens interakties met bijwoorbeeld artsen opstellen. Een zelfverzekerde houding met een redelijke op argumenten gebaseerde wijze van overtuigen is daarbij van groot belang (zie ook Lee \& Ofshe, 1981). Zelfverzekerdheid kan zich niet alleen uiten in het zich rationeel opstellen tijdens overleg, maar ook door te laten zien dat men de verantwoordelijkheid aankan en in staat is zelfstandig te werken.Verpleegkundigen zullen meer gemotiveerd zijn om een zelfverzekerde houding aan te nemen, naarmate zij zich zelf meer gebonden achten aan de doelstelling van Integrerende Verpleegkunde. Als verpleegkundigen zich zelf gebonden achten aan het welslagen van Integrerende Verpleegkunde, zullen ze meer gemotiveerd zijn om handelingsruimte te verkrijgen en 
on deze rumte te willen verdedigen. Ook is het van belang dat andere betrokkenen zoals artsen en de verpleegkundige leiding owertuigd zijn of raken wan het nut van hitegrerende Verpleeghunde. In dat geval zullen ze minder snel de afgestane ruimte terug ewser.

Veen onderschejd nast een rationele op argumenten gebaseerde beînloeding (de probleemoplossende beinvloedingsstrategie) nog andere bennvloedingsstrategieën. Sommige beinvioedingstrategieën dragen een rationeel karakter. Dat wil zeggen dat door middel van witwisseling van argumenten gezocht wordt naar een oplossing. Minder rationele beinvloedingsstrategieën zjn, direkt of indirekt gericht op de emoties van anderen. Ook kunnen de strategieen meer of minder expliciet zijn. Een beinvloedingspoging is expliciet indien deze openlik en daardoor beter herkenbaar is. Veen noemt vier beinvloedingsstrategieën:

- een probleemoplossende benadering, warbij openlijk op rationele wijze getracht wordt voor elk van de partijen een zo bevredigend mogelijke oplossing te vinden.

- een konfronterende benadering, wastrbij de beínvloedende partij er op gericht is de andere partij tot een bepaald gedrag te dwingen om hierdoor voor zichzelf een zo gunstig mogelijke uitkomst te krijgen

- situationele manipulatie, waarbij men impliciet mar wel rationeel tot een voor ieder anvaardbaar compromis tracht te komen. Doordat het experiment is goedgekeurd door de direktie van het ziekenhuis en door de besturen van de klinieken waar het experiment plaatsvindt, kunnen verpleegkundigen wanneer anderen bepaalde veranderingen willen tegenhouden bijvoorbeeld terloops wijzen op de formele goedkeuring van de direktie en het kliniekbestunur

- psychologische manipulatie, waarbij impliciet en op irrationele wijze getracht wordt, door bijvoorbeeld in te spelen op de emoties van anderen, zo ongemerkt mogelijk persoonlijk, woordeel te halen (bijwoorbeeld door te zeggen dat je de ander deskundig windt of dat je iemand graag mag).

Over het algemeen is de probleemoplossende strategie de meest effektieve voor het behouden van handelingsruimte. Veen (1982) stelt dat de minder-machtige er goed aan doet de meer-machtige zo veel mogelijk probleemoplossend te beinvloeden en met name konfrontatie zoweel mogelijk uit de weg te gaan.

Emans (1988) vindt twee dimensies die ten grondslag liggen aan de perceptie van beünloedingsstrategie informeel/formeel. Emans konkludeert: "In hwn denken over machigebruik maken mensen woral onderscheid tussen aan de ene kant konfronterende methoden en aan de andere kan koöperatieve methoden van machgebruik. In hun onderlinge beinwloedingsprocessen hebben zij een primaire neiging tot toepassing wan de laatsigenoemde soort. Ze verwachten dadrvan het meeste succes. Bovendien verwachten ze er een gunstige sociaal-emotionele uirwerking wan op hun verstandhouding met anderen. Konfronterend machtgebnik daarentegen heeft iets onweiligs. Men riskeen er onaangename situaties mee" (p. 147).

We kunnen vaststellen dat bij het verkrijgen en behouden van handelingsruimte, niet alleen statuskarnkteristieken een rol spelen maar ook andere faktoren wan belang zijn, zoals een groepsgerichte houding, het zich gebonden achten aan de doelen van Integrerende Verpleegkunde en de wijze watop geprobeerd wordt inwloed uit te 
oefenen. Indien verpleegkundigen bovendien de extra ruimte weten waar te maken, door de (nieuwe) taken in de beleving van andere organisatieleden met succes te vervullen, dan moeten verpleegkundigen in staat geacht worden meer macht te krijgen en vast te houden.

Terwijl de 'Expectation State Theory' aangeeft dat de machts- en prestige-ordening vastgesteld kan worden aan de hand van de feitelijke taakbijdrage, de handelingsruimte, de evaluatie van de taakbijdrage en de inwloed op groepsbeslissingen, kan volgens Veen (1982), de macht van een persoon worden gëndiceerd aan de hand van:

1) de invloed die de persoon heeft op groepsbeslissingen,

2) de mate waarin anderen afhankelijk zijn van de persoon voor het uitvoeren van aktiviteiten of het nemen van beslissingern, en

3) de mate warin de persoon niet afhankelijk is van anderen en zelfstandig kan beslissen.

Samenvattend wordt verwacht dat verpleegkundigen in grotere mate in staat zullen zijn de tijdelijk verkregen handelingsruimte te konsolideren en blijvend meer macht te verwerven binnen de organisatie indien zij $a$ de ruimte gebruiken door een grotere bijdrage te leveren aan de patiëntenzorg, $b$ deze grotere bijdrage positief wordt geëvalueerd (succes), $c$ zij zich gebonden achten aan het realiseren van het verpleegkundig model, $d$ zich groepsgericht opstellen en $e$ zich zelfverzekerd en probleemoplossend opstellen gedurende interakties met bijwoorbeeld artsen en de verpleegkundige leiding.

\section{Hypothesen}

1. Door Integrerende Verpleegkunde zullen verpleegkundigen een ruimere taak krijgen in de patiëntenzorg

2. Wanneer verpleegkundigen deze handelingsruimte omzetten in een grotere taakbijdrage zullen zij hun machtspositie versterken in de organisatie, in termen van:

- de invloed op beslissingen

- de mate waarin anderen afhankelijk zijn van verpleegkundigen

- de mate waarin verpleegkundigen onafharkelijk zijn van anderen

3. Versterking van de machtspositie zal meer platsvinden indien verpleegkundigen:

a. zich in de samenwerking probleemoplossend gedragen

b. blijk geven van een groepsgerichte houding

c. zich zelfverzekerd opstellen

d. hoger scoren op diffuse statuskarakteristieken (senioriteit)

e. hoger scoren op specifieke statuskarakteristieken (bekwaamheid)

f. zich gebonden achten aan het realiseren van het model

$g$ positief worden beoordeeld door andere leden van de organisatie (succes/positieve evaluatie). 


\subsection{Macht als 'groeiende koek'}

Veen (1982, p. 145) stelt dat wanneer "macht als een groeiende koek beschouwd mag worden (...) het mogelijk is dat degenen met minder invloed hun invloed kunnen vergroten zonder dat dit ven koste gaat wan degenen met meer invloed. Het is in dat geval zelfs mogelijk dat beide partijen meer te vertellen krijgen". Het moet niet uitgesloten worden dat door patiênttoewijzing zowel de verpleegkundige als de patiênt vindt dat de eigen invloed op de zorg toeneemt. Ook wanneer individuele verpleegkundigen meer met artsen moeten gaan overleggen is het mogelijk dat beide vinden dat ze meer invloed (op elkaar) krijgen.

Tannenbaum (1966) en Tannenbaum, Kavcic, Rosner, Vianello en Wieser (1974) vinden in hun onderzoek naar de gevolgen van participatie in bedrijven op de machtsverhoudingen in die bedrijven, ondersteuning voor de "groeiende koek' apvatting. "Organizations" however, dispense social and psychological reward such as power, status, prestige, and approval in addition to material and economic ones, and the notion of an expandable "piet of these rewards has been seriousty neglected if not disputed in the literature (...). The data of this research as well as of previous work however, suggest that these sacial functions are indeed expandable (or contractable) in organizations" (1974, p. 218). "The effective, participative organization is likely to be characterized by influential leaders and members, by a high total amount of control" (1974, p. 195).

Verwacht mag worden dat verpleegkundigen meer in staat zullen zijn hun positie te versterken wanneer dit samengaat met de versterking van de positie van andere leden van de organisatie en minder indien dit ten koste gaat van de positie van anderen. Hoewel er geen voorspelling wordt gedaan over de gevolgen van Integrerende Verpleegkunde voor de positie van de verpleegkundige leiding en artsen, zal wel nagegaan worden of vergroting van de invloed van verpleegkundigen gevolgen heeft voor de invloed van de verpleegkundige leiding en artsen.

\subsection{Gevolgen van taakverruiming voor individuele verpleegkundigen}

Er kunnen twee vormen van taakwerruiming onderscheiden worden, namelijk horizontale en vertikale taakverruiming (zie Veen, 1982, hoofdstuk 7). Horizontale taakverruiming houdt in dat er nieuwe elementen aan de taak of nieuwe taken aan een funktie worden toegevoegd, waardoor er meer afwisseling in de werkzaamheden ontstast. Vertikale taakverruiming betekent dat men aan meer fasen van het produktieproces een bijdrage levert, zoals de planningsfase, de uitvoeringsfase, de evaluatie en de bijsturing van het proces. Vertikale differentiatie heeft tot gevolg dat iemand een grotere verantwoordelijkheid krijgt en meer zelfstandig kan plannen, handelen en beslissen. Veen stelt dat vertikale en horizontale taakverruiming meestal samengaan. Ook Integrerende Verpleegkunde beoogt horizontale en vertikale taakverruiming. Bij horizontale taakverruiming valt te denken aan bijvoorbeeld de extra taken op het gebied van de begeleiding van patiènten of de samenwerking met andere disciplines en bij vertikale taakverruiming aan meer koördinerende taken. Integrerende Verpleegkunde houdt in dat binnen de verpleegkundige discipline taken en verantwoor- 
delijkheden worden gedecentraliseerd. Het is gebleken dat decentrale besluitvorming bij het uitvoeren van komplexe taken de voorkeur heeft (zie bijwoorbeeld Veen \& Wilke, 1984). De (verpleegkundige) patiëntenzorg wordt gekenmerkt door veel taken met een gemiddeld hoge komplexiteit. Ook moeten verpleegkundigen vaak taken uitvoeren waarbij de aard en omvang van de werkzaamheden voor een groot deel onvoorspelbaar zijn (spoedopname, komplikaties) en waarbij ook de sociale en materiële omgeving veelal onvoorspelbare faktoren herbergt, bijwoorbeeld een patiënt die erg emotioneel reageert, andere disciplines die werkzaamheden verstoren, onderzoeksuitslagen die op zich laten wachten enz.. Het blijkt dat bij het uitwoeren van werkzaamheden met grote 'omgevingsonzekerheid', een decentrale besluitvormingsstruktuur het meest wenselijk is, mits de groepsleden kompetent zijn (Tuijl \& Bodt, 1988).

Uit onderzoek blijkt dat door taakverruiming personen meestal meer tevredenheid in hun werk gaan ervaren en dat taakverruiming veelal de motivatie werhoogt (zie voor een overzicht Veen, 1982, hoofdstuk 7). Dit blijkt echter niet onder alle omstandigheden het geval te zijn. Van belang is onder andere of de persoon over voldoende vaardigheden en kennis beschikt om de niewwe taak uit te kunnen voeren en of de taakdoelen duidelijk zijn.

Verondersteld mag worden dat Integrerende Verpleegkunde meer vaardigheden, kennis en inzicht vraagt van individuele verpleegkundigen, met name op het terrein van de koördinatie van de zorg, de samenwerking met anderen en de psycho-sociale zorg. Het is mogelijk dat Integrerende Verpleegkunde op de genoemde terreinen onzekerheid zal veroorzaken bij een verpleegkundige. Onzekerheid refereert naar het ervaren van een deficiëntie in bekwaamheid. Te denken valt daarbij bijwoorbeeld aan onzekerheden als "Moet ik deze patiënt vragen waarom hij/zij zo stil is, of kan ik hem/haar beter met rust laten?", "Moet ik dit aan de zaalarts doorgeven of kan ik dat beter niet doen?", "De patiënt kan gezien diens toestand naar huis, maar krijgt de patiënt thuis voldoende verzorging?", "Hoe bereid ik de patiënt voor op de gevolgen van de operatie?". Bekwaamheid wordt met name bepaald door de opleiding en de ervaring van verpleegkundigen (senioriteit). Verwacht wordt dat verpleegkaundigen naarmate zij minder opleiding hebben genoten en minder ervaring hebben (lage senioriteit), zij als gevolg van de taakvemuiming welke Integrerende Verpleegkunde met zich mee brengt, meer onzekerheid zullen ervaren.

\section{Het reduceren van onzekerheid}

Het verkrijgen van de benodigde waardigheden en inzichten op de genoemde terreinen, is veelal veel minder eenvoudig dan bij problemen van bijwoorbeeld verpleegtechnische aard. Vragen zullen weliswaar ook ontstaan ten aanzien van andere onderdelen van de zorg, bijvoorbeeld "Heeft de patiënt koorts?", "Hoe leg ik dit infuus aan?", "Verloopt de verzorging van de wond naar tevredenheid?", maar antwoorden op dergelijke vragen zijn veelal beschikbaar en deze vragen komen ook bij taakgericht verplegen voor. Ook bestaat over de gewenste oplossing veel meer overeenstemming. Bij onzekerheid op deze terreinen is min of meer objektieve informatie voor handen of bestaan er algemeen aanvaarde standaards en kriteria. Wanneer een persoon een lichaamstemperatuur heeft van ruim boven de $37^{\circ} \mathrm{C}$ zal een ieder konkluderen dat de persoon koorts heeft. 
Op het gebied van de begeleiding van patiënten, de koördinatie en planning van de zorg of de samenwerking met anderen, zal het veel lastiger zijn om aan te geven wat die moeilijkheid precies is, welk doel gewenst is en op welke wijze het doel bereikt kan worden. In dergelijke situaties, waar objektieve of gestandaardiseerde informatie niet of onvoldoende voor handen is, blijken mensen geneigd te zijn om relevante informatie te verkriggen uit subjektieve bronnen (Festinger, 1954; Gerard, 1963). Verpleegkundigen kunnen problemen op het gebied van de begeleiding van patiënten, de samenwerking en de koördinatie van die zorg onderling bespreken. Dit door bijvoorbeeld na te gaan hoe kollega"s vergelijkbare moeilijkheden aanpakken, door hen om advies te vragen, door na te gaan of zij eenzelfde indruk hebben van een patiënt enz. Verwacht wordt dat verpleegkundigen, indien zij als gevolg van de taakverruiming meer onzekerheid ervaren, zij meer behoefte krijgen aan interakties met kollega's. De processen die plaatsvinden bij de uitwisseling van informatie uit subjectieve bronnen, kunnen in termen van sociale vergelijkingsprocessen beschreven worden. Hoewel er bimen de Sociale Vergelijkingstheorie (Festinger, 1954; Suls \& Miller, 1977) veel meer sociale verschijnselen worden behandeld dan hetgeen hiervoor is beschreven, kunnen inzichten uit de theorie gebruikt worden om aan te geven onder welke omstandigheden, de behoefte aan interakties zal toenemen. Terwijl uitwisseling van sociale informatie volgens de theorie op vele manieren kan plaatsvinden (zie bijvoorbeeld Jones \& Gerard, 1967, p. 321-330; Cottrell \& Epley, 1977), beperkt deze studie zich tot informatie-nitwisseling middels overleg.

\section{Voonwaarden voor sociale vergelijking}

Er kunnen een aantal faktoren onderscheiden worden die van invloed zijn op de relatie tussen onzekerheid en (de behoefte aan) sociale vergelijking. Het is gebleken dat mensen onder bepaalde omstandigheden, ondanks het ervaren van onzekerheid en de aanwezigheid van vergelijkingspersonen, toch trachten zich aan sociale vergelijking te onttrekken. Naast de behoefte aan onzekerheidsreduktie blijkt er namelijk bij mensen een behoefte te bestaan het zelfbeeld (self-esteem) te beschermen of te versterken (self-enhancement; zie bijvoorbeeld Hakmiller, 1966; Thornton \& Arrowood, 1966; Conolley, Gerard \& Kline, 1978; Gruder, 1977; Wills, 1986). Wanneer mensen verwachten dat uit de vergelijking informatie naar voren komt die bedreigend is voor het zelfbeeld, dan zal de behoefte aan sociale vergelijking als gevolg van onzekerheid afnemen (Brickman \& Bulman, 1977). Een verpleegkundige zal een gemaakte fout niet snel naar voren brengen wanneer deze vermoedt dat kollega's hier afkeurend of spottend op zullen reageren. Een verpleegkundige zal een tekort aan vaardigheden niet naar voren brengen indien hij of zij denkt dat daar negatief over zal worden geoordeeld. ("Jij kunt ook niet met mensen omgaan", "Kun jij nou niets zelfstandig doen").

Een werpleegkundige zal in mindere mate verwachten dat kollega's negatief zullen reageren, indien deze verpleegkundige denkt dat kollega's vergelijkbare onzekerheden ervaren. Uit onderzoek naar de betekemis van sociale vergelijkingsprocessen in de reductie van onzekerheid blijkt er over het algemeen een sterke voorkeur voor interakties met 'gelijke' anderen (zie bijvoorbeeld Schachter, 1959; Gordon, 1966; Gruder, 1977; Salancik \& Pfeffer, 1978; Molleman, Pruyn \& Van Knippenberg, 1986; Goethals, 1986). In deze studie verstaan we onder 'gelijk', de mate waarin verpleeg- 
kundigen verwachten dat kollega's globaal dezelfde houding hebben ten aanzien van de takkerruiming en ten aanzien van deze taken vergelijkbare onzekerheden ervaren (cf. Castore \& DeNinno, 1977; Wheeler \& Zuckermam, 1977). Verwacht wordt dat de behoefte aan overleg met kollega's als gevolg van onzekerheid afneemt naarmate de gepercipieerde gelijkheid ('similarity") kleiner is en de verwachte reacties meer bedreigend zijn woor het zelfbeeld.

Er kunnen op een verpleegeenheid sociale nomen bestaan die openlijke sociale vergelijking op bepaalde dimensies tot onwenselijk gedrag maken (cf. Brickman \& Bulman, 1977; Fishbein \& Ajzen, 1975; Fox, 1980). Verwacht wordt dat naarmate verpleegkundigen ervaren dat vanwege sociale normen overleg ongewenst is, men als gevolg van het ervaren van onzekerheid minder geneigd zal zijn zich openlijk met anderen te vergelijken. Opvattingen als "je behoort elkaars funktioneren niet te bespreken" of "praten is geen werken", kunnen verpleegkundigen er van weerhouden onzekerheden naar voren te brengen.

Een vierde faktor die van invloed kan zijn op de relatie tussen het ervaren van onzekerheid en de behoefte hier met anderen over te praten, is de door verpleegkundigen gepercipieerde instrumentaliteit van sociale vergelijking voor het reduceren van onzekerheid (vergelijk Gujot, 1978; Wills, 1986; Suls, 1986). Uit een studie van Molleman et al. (1986) blijkt, dat alleen wanneer men sociale vergelijking als instrumenteel ervaart, onzekerheid leidt tot een grotere behoefte aan interakties met anderen. Naast owerleg kunnen personen, mede afhankelijk van de situatie, andere gedragingen als instrumenteel ervaren voor het reduceren van onzekerheid (Folkman en Lazarus, 1980; Folkman, 1984). Naast overleg kunnen bijvoorbeeld de volgende reacties genoemd worden (Molleman, Krabbendam, Annyas, Schraffordt Koops, Sleijfer \& Vermey, 1984; Molleman \& Van Knippenberg, 1987): openlijke emotionele reacties (afreageren, geïrriteerd raken, kwaad worden), niet openlijk maar wel op de reductie van onzekerheid gericht gedrag (voor zichzelf problemen analyseren en naar oplossingen zoeken; vergelijk de term 'self-instruction' van Weisman \& Sobel, 1979) en niet openlijke defensieve reacties (ontkemnen, negeren, gespannen raken).

\section{Hyporhesen}

Samengevat wordt het volgende verwacht:

4. Naarmate verpleegkundigen minder ervaring hebben (senioriteit) en minder opleiding hebben genoten, zulien zij door de taakverruiming van Integrerende Verpleegkunde meer onzekerheid ervaren

5. Door onzekerheid zal de behoefte aan overleg met kollega's toenemen en dit meer naarmate

a. een verpleegkundige verwacht dat kollega's vergelijkbare onzekerheden ervaren en verwacht dat hun reacties niet bedreigend zijn voor het zelfbeeld

b. een verpleegkundige overleg als instrumenteel ervaart voor het reduceren van onzekerheid

c. een verpleegkundige verwacht dat andere verpleegkundigen overleg als instrumenteel percipiëren (sociale norm). 
In Figuur 3-1 worden de in dit hoofdstuk besproken begrippen en hun onderlinge relaties weergegeven. In hoofdstuk 6 wordt ingegaan op de operationalisatie van deze begrippen.

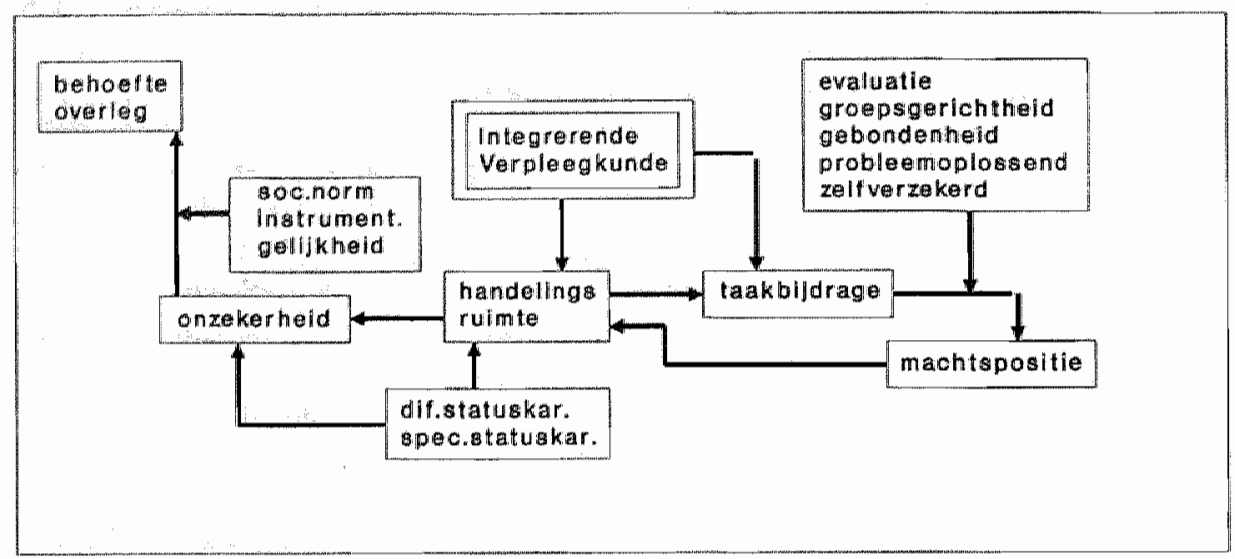

Figum 31 Overzicht van de besproken begrippen en hun veronderstelde onderlinge rejaties (soc.norm =sociale norm; instrument $=$ waargenomen instrumentaliteit van overleg; probleemoplossend $=$ probleemoplossende beinvloedingsstrategie, dif.statuskar $=$ diffuse statuskarakteristie ken: spec.statuskar =specifieke statuskarakteristieken) 


\section{HOOFDSTUK 4 METHODE VAN ONDERZOEK}

In dit hoofdstuk wordt ingegaan op de algehele onderzoeksopzet. Eerst wordt aandacht besteed aan de selectie van de verpleegeenheden waar het onderzoek heeft plaatsgevonden. Daarna worden de beslissingen verantwoord die zijn genomen bij de inrichting van het onderzoek. Tenslotte wordt ingegaan op de onderzoeksprocedure. De meetinstrumenten waarmee de gegevens zijn verzameld alsmede de wijze van selectie van de respondenten en hun kenmerken, worden beschreven in de twee volgende hoofdstukken, waar respektievelijk ook de resultaten betreffende de patiënten (hoofdstuk 5) en de resultaten betreffende de verpleegkundige organisatie (hoofdstuk 6) uiteen worden gezet.

\subsection{De selektie van verpleegeenheden}

Het Academisch Ziekenhuis Groningen bestaat uit een tiental klinieken zoals de chirurgische kliniek, de kliniek voor interne geneeskunde, de kinderkliniek enz.. Binnen elke kliniek bevinden zich diverse verpleegeenheden, welke veelal gekoppeld zijn aan én of meerdere medische (super-)specialismen. Binnen de chirurgische kliniek bestaan verpleegeenheden voor bijvoorbeeld traumatologie, urologie, oncologie en plastische chirurgie. Medio 1983 werd door de direktie van het ziekenhuis toestemming gegeven voor een experiment met het model Integrerende Verpleegkunde binnen twee klinieken. Het experiment moest beperkt blijven tot vier verpleegeenheden, zodat in principe in elk van deze klinieken twee verpleegeenheden betrokken konden worden bij het projekt. Het projekt moest geëvalueerd worden, zodat beleidskonklusies aan het experiment konden worden verbonden. Om deze reden was het van belang dat de experimentele verpleegeenheden min of meer representatief genoend konden worden voor het gehele ziekenhuis. De directie hechtte met andere woorden veel belang aan een hoge externe validiteit van de onderzoeksresultaten.

De selektie van klinieken en verpleegeenheden heeft enkele methodologische problemen veroorzaakt. In de eerste plaats was het voor de verpleegdienst van belang dat het experiment zou slagen en de uitkomsten positief zouden zijn. Daarnaast was het onontkoombaar dat de experimentele verpleegeenheden, verpleegeenheden zouden moeten zijn die bereid en gemotiveerd zouden zijn om aan het experiment deel te nemen. Vanwege de hiërarchische struktuur van de verpleegkundige organisatie in het ziekenhuis is bij de selektie van de verpleegeenheden in eerste instantie kontakt gelegd met de coördinerend hoofdverpleegkundigen (de CHV is lid van een kliniekbestuur). Drie klinieken ( $\mathrm{CHV}$ "s) bleken bereid om aan het experiment deel te nemen. Binnen deze klinieken stonden leidinggevenden van zeven verpleegeenheden positief tegenover deelname aan het experiment. Redenen om niet deel te nemen waren bijvoorbeeld: men vond de eigen eenheid niet representatief; een te grote werkdruk; een reorganisatie, verbouwing of een naderende relocatie van de eenheid; gebrek aan motivatie. In verband met de representativiteit viel één van de drie klinieken (psychiatrie) af. 
Binnen elk van de twee overgebleven klinieken --de chirurgische kliniek en de kliniek voor obstetrie en gynaecologie-- werden, na gesprekken met de verpleegkundigen van de verpleegeenheden waarvan de leiding wich bad aangemeld, twee eenheden geselekteerd.

Besloten werd de metingen op de experimentele verpleegeenheden te vergelijken met die op kontrole verpleegeenheden. Het is in verband met de interne validiteit van de evaluatie van belang dat experimentele en kontrole verpleegeenheden bij aanvang var het projekt op relevante kenmerken zo veel mogelijk op elkaar lijken (bijvoorbeeld wat de kategorie patiênten, de motivatie binnen het verpleegkundig team en de inhoud van de verpleegkundige zorg betreft). Tevens is het wenselijk dat kontrole en experimentele verpleegeenheden zo veel mogelijk onafhankelijk van elkaar funktioneren en er miet te veel kontakt is tussen experimentele en kontrole verpleegeenheden, doordat bijwoorbeeld verpleegkundigen van experimentele verpleegeenheden gedurende het experiment op een kontrole verpleegeenheid gaan werken. Omdat het niet mogelijk is een kontrole verpleegeenheid te vinden die volledig aan de genoemde kriteria voldoet, is er naar gestreefd zo veel mogelijk kontrole verpleegeeriheden bij het onderzoek te betrekken, waarbij de ene kontrole verpleegeenheid meer zal voldoen aan het ene kriterium en een andere kontrole verpleegeenheid aan een ander kriterium. Dit in de verwachting dat de kontrole verpleegeenheden bij aanvang van de implementatie tezamen redelijk vergelijkbaar zijn met de experimentele verpleegeenheden. Om voorgaande redenen werden kontrole verpleegeenheden benaderd in

1. dezelfde twee klinieken waar de experimentele verpleegeenheden waren gelokaliseerd

2. een andere kliniek van het Academisch Ziekenhuis Groningen

3. een zelfde kliniek van een ander academisch ziekenhuis (Academisch Ziekenhuis Utrecht).

In total werden zeven verpleegeenheden bereid gevonden om als kontrole verpleegeenheid aan het onderzoek deel te nemen. Het betreft drie chirurgische eenheden (waarvan éen in het Academisch Ziekenhuis te Utrecht), twee gynaecologische eenheden (waarvan ến in Utrecht) en twee eenheden uit de kliniek voor interne geneeskunde. Het zal duidelijk zijn dat verpleegeenheden niet random zijn geselekteerd en niet random zijn toegewezen aan de experimentele en de kontrole konditie.

In het kader van de selektie van experimentele verpleegeenheden is in mei 1983 aan de verpleegkundige leiding van elke verpleegeenheid van het ziekenhuis gevraagd, de eigen eenheid ten aanzien van een aantal kondities te beoordelen, zoals de motivatie van de verpleegkundigen en de samenwerking met de artsen. Hen werd gevraagd hoe belangrijk zij elk van de kondities vinden voor het wel of niet deelnemen aan het experiment en hoe zij de kondities binnen de eigen verpleegeenheid evalueren in termen van gunstig/ongunstig. In Tabel $4-1$ worden de 13 items die aan de verpleegkundige leiding werden voorgelegd in het kort weergegeven. De items zijn in deze tabel geordend van 'gemiddeld het meest belangrijk volgens de leiding' tot 'gemiddeld het minst belangrijk'. Er bestaat een grote overeenstemming tussen leidinggevenden over de mate waarin de 13 onderwerpen van belang zijn voor het introduceren van Integrerende Verpleegkunde op een verpleegeenheid. De motivatie 
Tabel 4 1 . Een dertiental kondities beoordeeld door de werpleegkundige leiding van "experimentele", 'kontrole" en "overige' verplleegeenheden. De leidinggevenden hebben bij elke konditic aangegeven hoe belangrijk zij deze vinden voor het invoeren van Integrerende Verpleagkunde (relewatue: range 0-3) en hoe zij de betreffende konditie op de eigen verpleegeenheid inschatten (ewaluatie: range -2 tot +2 ). Gegeven wordt het gemiddelde gewogen oordeel Als relevantie $=r_{2}$ evaluatie $(e v)=$ en thet antal observaties $=\mathbf{n}_{n}$ dan is de gewogen score $(\mathrm{gtw})$ : Er e

n

\begin{tabular}{cccc}
\hline Konditie & Experimentele & Kontrole & Overige eenheden \\
cenheden $(n=4)$ & eenheden $(n=5)$ & $(n=79)$ \\
ev gew & ev gew & ev gew
\end{tabular}

1. Motivatie hoofaverpleeg-

kundige

$1.7 \quad 5.2$

$1.2 \quad 3.6$

2.7

2. Samenwerking ver-

pleegkundigen op af-

deling

$2.0 \quad 6.0$

$1.2 \quad 3.6$

1.3

3.7

3. Motivatie verpleeg-

kundigen

1.54 .5

$1.0 \quad 2.6$

.4

1.2

4. Samenwerking met

artsen

$1.5 \quad 4.0$

.6

1.6

.3

.8

5. Samenwerking hoofdverpleegkundigen kliniek onderling

$\begin{array}{rrrrrr}1.5 & 4.0 & .4 & .8 & .8 & 2.2 \\ .8 & 2.0 & -.1 & -.6 & -.2 & -.4 \\ -.2 & -.8 & -.2 & -1.0 & -.5 & -1.4\end{array}$

7. Overlegruimte

$1.7 \quad 3.5$

1.2

3.0

$.7 \quad 1.6$

9. Personeelsopboww

(Inservice, $\mathrm{HBO}$, etc.)

1.22 .2

.6

1.4

.5

9

10. Opnameduur

$1.0 \quad 2.0$

1.3

2.5

$.0 \quad-1$

11. Aantal specialismen

$-.2 \quad-1.0$

2.4

$.6 \quad 1.0$

12. Soort specialisme

$1.7 \quad 3.5$

$1.0 \quad 2.2$

$.7 \quad .8$

13. Grootte afdeling

$1.7 \quad 2.5$

1.8

2

.2

Totaal gemiddelde

2.9

1.6

1.06

Gemiddelden mei ongelijke letter, verschillen signifikant van elkaar $(\mathrm{p}<.05)$ 
van de hoofdverpleegkundige (item 1) wordt door alle respondenten "erg belangrijk gevonden" (score 3 bij een range vani 0 tot 3 ). De bovenste zeven items uit Tabel 4-1 worden allen 'belangrijk' tot 'erg belangrijk gevonden' (gemiddelden $>2.5$ ). De overige zes items worden minder belangrijk gevonden (gemiddelden tussen 1.5 en 2.5 ). Het is binnen de attitude-theorie gebruikelijk de evaluatie van een item te wegen met de waargenomen relevantie wan dat item (vergelijk Fishbein \& Ajzen, 1975, p. 29). De gewogen score (gew) wordt per konditie weergegeven in Tabel 4-1. De gemiddelde oordelen worden gegeven, uitgesplitst naar experimentele (kolom 2), kontrole (kolom 3) en overige verpleegeenheden (kolom 4). De omstandigheden voor het invoeren van Integrerende Verpleegkunde worden door de leiding op de experimentele verpleegeenheden gunstiger beoordeeld dan door de leiding van de 'overige' eenheden: $F(2,85)=$ $3.37, p<.05$. Voor geen van de specifieke kondities zijn de verschillen signifikant. De verschillen zijn nog het grootst ten aanzien van de opnameduur en de samenwerking met artsen $(\mathrm{p}<.10)$. Gelet op de grote overeenstemming tussen leidinggevenden uit de drie groepen over de relevantie van deze twee items ( $\mathrm{p}$ waarden $>.50$ ), moeten deze verschillen tussen de groepen toegeschreven worden aan verschillen in 'evaluatie' $(p<.10)$. De gemiddelde evaluatie wordt daarom eveneens gegeven in Tabel 4-1. De respondenten vinden overigens de samenwerking met artsen relevant (gemiddelde bedraagt 2.7) en dle opnameduur van minder belang (gemiddelde bedraagt 1.9). De experimentele en kontrole eenheden verschillen niet signifikant van elkaar.

Het voorgaande wijst erop, dat door de wijze van selektie de externe validiteit mogelijk meer wordt bedreigd (de mate waarin de experimentele eenheden representatief zijn) dan de interne validiteit (hier: de mate waarin experimentele en kontrole eenheden bij aanvang op relevante karakteristieken vergelijkbaar zijn).

Patiënten die in het ziekenhuis worden opgenomen kunnen niet willekeurig aan een experimentele of aan een kontrole verpleegeenheid worden toegewezen. Dit lijkt echter niet erg problematisch, daar er geen aanleiding is te veronderstellen dat patiënten die opgenomen worden op experimentele verpleegeenheden bij opname op relevante kemmerken verschillen van patiënten die worden opgenomen op niet experimentele verpleegeenheden (zie 5.2).

\subsection{Het onderzoeksontwerp.}

Nadat de experimentele verpleegeenheden waren geselekteerd, werd in november 1983 een formele start gemaakt met de implementatie van Integrerende Verpleegkunde op de vier verpleegeenheden. In deze periode werd begonnen met het opzetten van het onderzoek. Aan de hand van sociaal wetenschappelijke inzichten en in overleg met het projektmanagement en de verpleegkundigen van de experimentele verpleegeenheden werden de meetinstrumenten ontworpen. Pas in mei/juni 1.984 kon een eerste meting plaatsvinden. De projektorganisatie wilde aan het eind van de experimentele periode (november 1985) de resultaten van het evaluatie-onderzoek ter beschikking hebben. Dit heeft tot gevolg gehad dat de laatste meting heeft plaatsgevonden in mei/juni 1985. In de periode tussen de eerste en laatste meting heeft er nog een derde meting plaatsgevonden (november/december 1984). Na de eerste meetperiode (mei/juni 1984) zijn er wijzigingen in de meetinstrumenten aangebracht (zie 5.1 en 6.1). 
De introduktie van Integrerende Verpleegkunde vergt de nodige tijd. Eventuele effecten kunnen dan ook pas na verloop van tijd verwacht worden. De momenten waarop het model nog geheel niet was ingevoerd en het model optimaal was ingevoerd, kan niet exact aangegeven worden. Het lijkt echter gezien de hiervoor gemaakte opmerkingen niet verdedigbaar -hetgeen wel de intentie is geweest-- te spreken van een voor-tussen- en na-meting.

Gelet op het voorgaande kan gesproken worden van een quasi- of pré-experimenteel design. Dat wil zeggen dat er sprake is van een experimentele en kontrole konditie zonder random toewijzing van verpleegeenheden aan kondities en verpleegkundigen en patiënten aan verpleegeenheden (Cook \& Campbell, 1979). Voorbeelden van bedreigingen voor de interne validiteit, naast 'selektie', die door Cook \& Campbell worden genoemd, zijn:

- diffusie of imitatie: dit treedt op indien bijvoorbeeld verpleegkundigen van experimentele en kontrole verpleegeenheden kontakt met elkaar hebben; verpleegkundigen van experimentele en kontrole verpleegeenheden wisselen ervaringen uit; instrumenten, materiaal of ideeën ontwikkeld in het kader van Integrerende Verpleegkunde worden door kontrole verpleegeenheden overgenomen (dienstrooster, opnameformulier, verpleegkundig dossier); verpleegkundigen van experimentele verpleegeenheden gaan werken op een kontrole verpleegeenheid, enz.

- het is waarschijnlijk dat de verpleegkundigen vam experimentele en kontrole verpleegeenheden niet neutraal staan ten opzichte van het experiment. Bovendien zijn ze op de hoogte van de konditie (experimenteel/kontrole) waarbinnen zij zelf funktioneren en zullen zij vermoedens hebben over de vraagstelling van het onderzoek. Dit kan de reacties van de respondenten --los van de feitelijke effecten-- in verschillende richtingen hebben beïnvloed. Deze reacties worden in de literatuur de 'reaktiviteit' van de onderzoekssituatie genoemd, waarbinnen diverse specifieke reakties zijn beschreven zoals het 'Hawthorn effect', 'kompensatorische rivaliteit', 'demand characteristics' (zie bijvoorbeeld Miller, 1972; Cook \& Campbell, 1979; Polit \& Hungler, 1987).

Naast de hierboven genoemde mogelijke bedreigingen van de waliditeit, kumnen ook de door Van de Vliert, Huismans, Krigger en Van der Leeuw (1986) beschreven betaen gamma-veranderingen interpretatieproblemen veroorzaken. Onder een alfa-verandering verstaan zij een verandering gemeten met een geijkt meetinstrument, dat een 'konstant' begrip meet. Een bèta-verandering wordt veroorzaakt doordat men antwoordkategorieën anders gaat waarderen. Het meetinstrument moet opnieuw geijkt worden, maar houdt nog steeds met het zelfde begrip verband. Verpleegkundigen vinden vór invoering van Integrerende Verpleegkunde hun taakbijdrage bijwoorbeeld 'redelijk groot' en na invoering -hoewel de bijdrage feitelijk is toegenomen-- nog steeds 'redelijk groot'. Voor aanvang wond men dat er een aantal taken 'bleven liggen' en omdat door Integrerende Verpleegkunde het verpleegkundig takenpakket omvangrijker is geworden, vindt men na invoering dat er nog steeds 'taken blijven liggen'. Gammaveranderingen tenslotte refereren aan een herdefiniëring van begrippen. Het is bijvoorbeeld mogelijk dat verpleegkundigen van experimentele eenheden door Integrerende Verpleegkunde onder 'psycho-sociale zorg' iets anders zijn gaan verstan. 
Indien men voor invoering hier 'het geven van informatie' onder verstond maar na inwoering tevens "het geven van instrukties', 'het aanleren van vaardigheden', 'het aundacht geven aan de emotionele reakties van de patiënt" en 'het sturen van een acceptatieproces".

Volgens Cook \& Campbell (1979) hangt het mede af van de aard van de verschillen tussen experimentele en kontrole verpleegeenheden, welke bedreiging van de validiteit van het experiment mogelijk of onwaarschijnlijk zijn. Op grond van het onderzoeksmateriaal zal achteraf een inschatting gemaakt moeten worden in welke mate deze faktoren een bedreiging wormen voor de validiteit van het onderzoek (vergelijk Cook \& Campbell, 1979, pag. 103-112).

\subsection{De procedure.}

Nadat de direktie wan het ziekenhuis toestemming had gegeven voor een experiment op vier verpleegeenheden, werd een projektgroep geïnstalleerd, waarna in samenwerking met de medewerkers belast met de inwoering, een onderzoekswoorstel werd opgesteld. Na de selektie van experimentele- en kontrole verpleegeenheden, werd dit voorstel ter goedkeuring voorgelegd aan de besturen van de twee klinieken waarbinnen het experiment zou plaatsvinden. Vervolgens werd het onderzoek geïntroduceerd op elk van de experimentele verpleegeenheden. De algemene koördinatie van het onderzoek vond plaats op centraal nivo.

Besloten werd dat gegevens verzameld zouden worden met behulp van vragenlijsten. Aan verpleegkundigen, de verpleegkundige leiding, patiënten en artsen werden vragenlijsten voorgelegd. Andere disciplines zoals paramedici, de medische registratie assistenten en medewerkers van de civiele dienst (o.a. schoonmaak personeel) werden niet bij het onderzoek betrokken.

Voor het vaststellen van de gevolgen van Integrerende Verpleegkunde voor de patiènt is het noodzakelijk na te gaan of er bij patiënten tijdens de opname veranderingen optreden. Daarom werd aan patiënten vlak na opname en vlak voor ontslag gevraagd een vragenlijst in te vullen.

Elke patiënt vulde twee maal een vragenlijst in. In principe gebeurce dit op de dag na opname en op de dag voor ontslag. Dit vond om uiteenlopende redenen ook wel op een andere dag plaats. Bijwoorbeeld wanneer een patiënt de dag na opname werd geopereerd, vervolgens naar een intensive care-afdeling ging om tenslotte weer terug te keren naar de verpleegeenheid. De dag voor ontslag vulden de patiënten in principe de tweede vragenlijst in. Ook dit kon echter om viteenlopende redenen enigszins varièren. De korrelatie tussen de werkelijke opnameduur en de periode tussen de twee metingen bedraagt .98.

Verpleegkundigen kregen van de verpleegkundige leiding van de eenheid aan het begin van elke onderzoeksperiode de vragenlijst. Zij retourneerden de vragenlijst in een gesloten enveloppe. De verpleegkundige leiding vulde in dezelfde periode ook een vragenlijst in. Met de verpleegkundige leiding wordt hier bedoeld, het hoofd van een verpleegeenheid (HVE) en het waarnemend hoofd van een verpleegeenheid (WHVE). Niet alle eenheden bescltikken over een WHVE. Op enkele verpleegeenheden zijn twee WHVE's werkzaam. 
Die artsen werden benaderd, die gedurende de 2 maanden voorafgaand aan de onderzoeksperiode het meest frequent -naar het oordeel van de verpleegkundige leiding-- op de verpleegeenheid werkzaam waren geweest. $\mathrm{Zij}$ werden in staat geacht een oordeel te kunnen geven over de verpleegkundigen. In de regel betrof dit de zaalarts (en/of de supervisor). Gezien de regelmatige wisseling van zaalartsen op verpleegeenheden, bleek het begin van een onderzoeksperiode vaak niet geschikt on hen de verpleegkundige werkwijze te laten beoordelen. Een zaalarts werd daarom gevraagd zijn oordeel te geven bij beëindiging van zijn/haar stage op de betreffende verpleegeenheid.

De verpleegeenheden werden van materiaal voorzien. De start van elke periode van dataverzameling werd centraal vastgestelc. Gedurende deze periode werd on de 2 à 3 weken de voortgang van het onderzoek met elk van de verpleegeenheden (eventueel telefonisch) besproken. De verdere organisatie vond decentraal plaats op de verpleegeenheden en was in handen van het verpleegkundig management van de verpleegeenheid. 


\section{HOOFDSTUK 5 \\ DE PATIENT: MATERIAAL EN RESULTATEN}

In dit hoofdstuk wordt eerst ingegaan op de inhoud van de vragenlijsten die aan de patiênten werden voorgelegd. Daarna wordt aandacht besteed aan de beschrijuing van de groep patiënten die is benaderd en aan de groep die feitelijk aan het onderzoek heeft deelgenomen. Nadat vervolgens enkele exploratieve analyses zijn beschreven, zullen de in het tweede hoofdstuk geformuleerde hypothesen worden getoetst. Het hoofdstuk wordt afgesloten met de bespreking van enkele diskussiepunten.

\subsection{De vragenlijsten}

$\mathrm{Na}$ de eerste meetperiode (mei/juni 1984) zijn er wijzigingen in de vragenlijsten voor patiënten aangebracht. De patiënten vonden enkele vragen en de instruktie bij sommige vragen niet duidelijk. Bovendien werd de vragenlijst te omvangrijk gevonden. Op grond van deze reakties en met behulp van enkele exploratieve analyses, zijn de meetinstrumenten aangepast en ingekort. Daar waar de instruktie bij vragen, de labels van antwoordkategorieën, het aantal antwoordkategorieën of de lay-out van vragen is gewijzigd, zal de eerste meting als pilot worden beschouwd. Dit wil zeggen dat het betreffende materiaal bij het toetsen van de hypothesen niet zal worden gebruikt. De wijze waarop andere begrippen werden gemeten, is niet veranderd. Het materiaal dat ten aanzien van deze begrippen in de eerste meetperiode is verzameld, is bij de toetsing van de hypothesen wel gebruikt. Bij de operationalisatie van enkele begrippen, zijn uitsluitend één of meerdere items verwijderd. De scores op de resterende items is wel bij de toetsing van de hypothesen gebruikt. Omdat, zoals eerder aangegeven werd, er geen sprake is van een zuivere 'voor-', 'tussen-' en 'na-' meting, zal de tijdsfaktor in eerste instantie niet in het onderzoeksontwerp opgenomen worden (en daarmee in de data-analyse niet als faktor). Bij secundaire analyses zal de tijdsfaktor eventueel wel betrokken worden.

De begrippen die zijn gebruikt bij de formulering van de hypothesen ten aanzien van de effekten van Integrerende Verpleegkunde voor patiënten, zijjn geoperationaliseerd door ến of meerdere items. Voor enkele van deze begrippen is het mogelijk geweest gebruik te maken van bestaande operationalisaties. Voor de meeste begrippen --hoewel ontleend aan meer algemene sociaal psychologische theorieën-- moesten bestaande operationalisaties worden aangepast of nieuwe worden gecreëerd. Dit vanwege de specifieke kontext van de interventie.

De patiënten vulden na opname en voor ontslag een vragenlijst in. In totaal werd door 616 patiënten twee maal een vragenlijst ingevuld. Daarnaast werd door 188 patiënten alleen de eerste wragenlijst ingevuld (zie 5.2.). De onderstaande betrouwbaarheidsanalyses en faktoranalyses zijn dan ook gebaseerd op maximaal 1420 observaties $(2 \times 616+188)$. De twee vragenlijsten verschilden onderling op enkele details. In de vragenlijst 'na opname' waren enkele vragen opgenomen die niet in de vragenlijst 'voor 
ontslag waren opgenomen en vice versa. Na opname betrof dit zes vragen over de leeftijd, de sexe, de burgerlijke staat, de genoten opleiding, het aantal ziekenhuisopnamen in het verleden en de duur van deze opnamen in het verleden. Vóór ontslag betrof dit vier vragen over patiënttoewijzing, zoals ervaren door de patiënt, namelijk:

- het aantal verschillende verpleegkundigen waardoor de patiënt per dag werd verzorgd,

- het aantal verschillende verpleegkundigen waardoor de patiënt tijdens de gehele opname werd verzorgd,

- de mate waarin de patiënt het idee had door een vaste verpleegkundige te zijin verzorgd, en

- de reaktie van de patiënt bij vragen over zijn behandeling of verzorging ("Dan ga ik naar een specifieke verpleegkundige", "Dan ga ik naar een verpleegkindige die in de buurt is" enz.).

Deze vier vragen zijn toegevoegd na de eerste meetperiode (mei/juni 1984). Tijdens de eerste periode werd door de verpleegkundige leiding uitsluitend aangegeven of er één of meer dan één verpleegkundige verantwoordelijk was geweest voor de verpleegkundige zorg gedurende de gehele opnameperiode van een patiënt. Het bleek dat deze vraag door verschillende leidinggevenden 'anders dan bedoeld' werd opgevat. Op een verpleegeenheid zonder patiënttoewijzing kan men namelijk van mening zijn dat de hoofdverpleegkundige (dus eén verpleegkundige) verantwoordelijk is voor de verpleegkundige zorg van elke patiênt. De eerste drie vragen, zoals hierboven weergegeven, die door de patiënt werden beantwoord en de vraag die door de verpleging over elke patiënt werd ingevuld, vormen samen de schaal 'patiënttoewijzing' (Cronbach's alpha bedraagt .56).

Invloed. De patiënten werd gevraagd aan te geven in welke mate zij vinden dat zij zelf invloed hebben op de zorgverlening. Aangezien het op voorhand niet duidelijk is of dit --in de beleving van patiënten-- ten koste gaat van de invloed van de verpleegkundigen en de artsen, hebben de patiënten ook een inschatting gemaakt van de invloedl van artsen en verpleegkundigen op de zorgverlening. De patiënten hebben hun eigen invloed en de invloed van artsen en verpleegkundigen op een achttal zorgaspekten beoordeeld. De interne konsistentie van deze acht items bedraagt voor de door de patiesnt gepercipieerde invloed van hem/haar zelf, van verpleegkundigen en van artsen respektievelijk $.84, .82$ en .82 (betrouwbaarheidscoëfficiënt Cronbach's alpha). Over elk van deze drie groepen items is een faktoranalyse uitgevoerd (principale komponenten analyse). Gelet op de verdeling van de oorspronkelijke variantie over de ongeroteerde faktoren en gelet op de mate waarin de geroteerde faktor-oplossing interpreteerbaar is (Varimax-rotatie), kunnen ten aanzien van de invloed van de patiënt, de verpleegkundige en de arts twee faktoren onderscheiden worden. De inhoud van de items, de faktorladingen matrices ma rotatie en de eigenwaarden van de ongeroteerde faktoren worden gegeven in Bijlage 1. Ten aanzien van de eigen invloed op de verzorging lijken patiénten onderscheid te maken tussen 'psychosociale zorg' en 'de organisatie van de zorg'. Ten aanzien van de invloed van verpleegkundigen en artsen maken patiënten onderscheid tussen 'verzorgende en begeleidende aspekten' en 'aspekten rond de behandeling' (respektievelijk de eerste en tweede geroteerde faktor bij verpleegkundigen en de tweede en eerste geroteerde faktor bij artsen). Aan de hand van de 
oorspronkelijke scores op de items zijn zes somvariabelen gekonstrueerd. De interne konsistentie van de zes schalen varieert van .71 tot .85 (Cronbach's alpha). In dit hoofdstuk wordt ingegaan op de door de patiënt waargenomen invloed van hem zelf op de zorg. De door de patiënt gepercipieerde invloed van verpleegkundigen en artsen op de zorg wordt besproken in respektievelijk hoofdstuk 6 en hoofdstuk 7 .

De hiervoor besproken vragen hebben betrekking op de door patienten waargenomen invloed van diverse personen op zijn of haar werzorging. In het tweede hoofdstuk is de verwachting uitgesproken dat mensen de door hen waargenomen invloed en veranderingen daarin, in zekere mate generaliseren naar gerelateerde dimensies. Wanneer een patiënt meer invloed gaat ervaren op zijn verblijf in het ziekenhuis, zal hij of zij mogelijk ook meer invloed gaan ervaren op het lichamelijk herstel of meer invloed gaan ervaren op de eigen gezondheid in het algemeen. Aan de patiënten werden 14 vragen voorgelegd. Over deze 14 vragen werd een faktoranalyse uitgevoerd (principale komponenten analyse). Een twee-faktoren oplossing blijkt na Varimax-rotatie goed te interpreteren. In navolging van Wallston, Wallston \& DeVellis (1978) kunnen deze twee faktoren benoemd worden als 'Internal Health Locus of Control' en 'Powerful others Health Locus of Control'. De eerste faktor bevat de items die betrekking hebben op de invloed van de patiënt zelf en de tweede faktor bevat de items die handelen over de invloed van artsen en verpleegkundigen (op bijvoorbeeld het genezingsproces). In bijlage II wordt de inhoud van de items gegeven en wordt de faktoranalyse beschreven. Aan de hand wan de scores op de oorspronkelijke items, zijn twee somvariabelen samengesteld. De interne konsistentie van de twee schalen bedraggt respektievelijk .71 en .68 (Cronbach's alpha).

Strategieën voor het hanteren van problemen. De door patiënten gehanteerde strategieën bij het oplossen van problemen werd gemeten aan de hand van een 'copingschaal'. Deze operationalisatie is afgeleid van een schaal die eerder werd gebruikt bij het meten van coping-strategieën bij patiënten (Molleman et al., 1984; Molleman \& Van Knippenberg, 1987). De schaal is gezien het specifieke onderwerp van onderzoek --namelijk 'de reakties van patiënten wanneer het verblijf in het ziekenhuis niet naar wens verloopt'-- aangepast (cf. Folkman \& Lazarus, 1980). Over de dertien items is een faktoranalyse uitgevoerd (principale komponenten analyse). Na Varimax-rotatie blijkt een oplossing met drie faktoren het meest interpreteerbaar. De faktoranalyse wordt besproken in Bijlage III. De drie faktoren kunnen benoemd worden als 'probleemoplossende strategieën' (faktor 1), 'ego-defensieve strategieën' (faktor 2) en 'konfronterende strategieën' (faktor 3). Aan de hand van de oorspronkelijke items zijn drie somvariabelen samengesteld. De interne konsistentie, Cronbach's alpha, bedraagt respektievelijk .62, .61 en .66. Deze betrouwbaarheidscoëfficiënten zijn niet hoog maar nog wel aanvaardbaar (cf. Nunnally, 1967, p. 210).

Kennis en stress. Aan de hand van twee vragen, hebben patiënten aangegeven hoe goed zij zichzelf geïnformeerd achten over hun ziekte en hun behandeling. De twee items korreleren onderling .72. Een schaal 'kennis' is gekonstrueerd aan de hand wan deze twee items.

Stress werd gemeten aan de hand van een tiental items uit de zelf-beoordelingsvragenlijst van Van der Ploeg, Defares en Spielberger (1980). Dit is een Nederlandse 
vertaling van de 'State - Trait Anxiety Inventory' van Spielberger, Gorsuch en Lusheme (1970). Zowel de 'State' als de "Trait" versie in de oorspronkelijke schaal bevatten 20 items. De interne konsistentie is zo hoog (zie bijvoorbeeld Molleman et al., 1986), dat uit spaarzaarnheidsoverwegingen is besloten, op grond van een betrouwbaarheidsanalyse over het materiaal uit de eerste observatieperiode (Cronbach's alpha is .94), tien items (uit de 'state' versie) te selekteren. Dit op grond van de item-totaal-korrelaties, waarbij een gelijk aantal 'positief'(bijvoorbeeld "Ik voel me prettig") en 'negatief'(bijvoorbeeld "Ik ben gespaninen") geformuleerde items is geselekteerd. De Cronbach's alpha over deze tien items bedraagt .93. Na spiegeling van de 'positieve' items is de somvariabele 'stress' gekonstrueerd.

Het nemen van initiatief en het verrichten van zelfzorg. Zes items betreffen de mate waarin de patiënt initiatief ontplooit. Deze items handelen bijvoorbeeld over het geven van de eigen mening, het aanknopen van een gesprek met een arts of een verpleegkundige en het vragen om informatie. Bij een faktoranalyse over de zes items (principale komponenten analyse) heeft alleen de eerste ongeroteerde faktor een eigenwaarde die groter is dan 1 , namelijk 3.36 ( $56 \%$ van de variantie). De coëfficiënt Cronbach's alpha over deze zes items bedraagt .84. Er is één somvariabele gekonstrueerd.

Tenslotte werd aan de patiënten een zestal vragen voorgelegd die betrekking hebben op de mate waarin door hen een aantal zelfzorgaktiviteiten zijn verricht. De items handelen over 'zichzelf wassen', 'naar het toilet lopen', 'aan- en uitkleden', 'in- en uit bed gaan', 'het bed opmaken' en 'de temperatuur opnemen'. De eerste ongeroteerde faktor (principale komponenten analyse) over deze zes items heeft een eigenwaarde van 3.09 (51,5\% verklaarde variantie). De tweede faktor heeft een eigenwaarde van $1.06(17,7 \%)$. Op grond hiervan is besloten één somvariabele 'zelfzorg' te konstrueren. Cronbach's alpha bedraagt .78 .

\subsection{Selektie en response}

\section{Selectie kriteria}

Voor elke patiënt die na aanvang van een onderzoeksperiode werd opgenomen, werd door de verpleegkundige leiding een 'selektieformulier' ingevuld. Van te voren waren in overleg met de leidinggevenden de volgende kriteria opgesteld:

- aangezien patiènten in principe de dag na opname en de dag voor ontslag een vragenlijst in vallen, moet de opnameduur minimaal 3 dagen zijn. Bij een kortere opname, zou de patiënt de eerste en de tweede vragenlijst op dezelfde dag of op elkaar volgende dagen moeten invullen. Dit werd als niet zinvol gezien

- een patiënt doet niet mee aan het onderzoek indien deze naar het oordeel van de verpleegkundige leiding lichamelijk niet in staat is deel te nemen (bijwoorbeeld:'te ziek', 'te veel pijn')

- een patiënt wordt niet gevraagd deel te nemen aan het onderzoek, indien deze, naar het oordeel van de verpleegkundige leiding, mentaal niet in staat is de vragenlijst in te vullen (bijvoorbeeld 'in de war", "dement") 
- overige redenen (bijvoorbeeld 'kombinatie van voorgaande redenen', 'patiënt is blind', 'beheerst de Nederlandse taal niet').

Een patiënt die na deze voorselektie in aanmerking kwam voor deelname aan het onderzoek, werd gevraagd of deze bereid was an het onderzoek deel te nemen. Indien de patiënt aangaf aan het onderzoek deel te willen nemen en ook deel te kunnen nemen (bijvoorbeeld 'kunnen lezen'), ontving de patiënt de viagenlijst en gaf deze, na deze ingevuld te hebben in een gesioten enveloppe terug aan de verpleging.

Het streven is geweest om tijdens elk van de drie observatieperiodes (mei/juni 1984, november/augustus 1984 en mei/juni 1985), per verpleegeenheid 30 patiënten bij het onderzoek te betrekken. In de praktijk is dit niet haalbaar gebleken. Deelname aan het onderzoek betekende een extra belasting voor met name de leidinggevenden van een verpleegeenheid. De duur van elke onderzoeksperiode waarin patiënten werden benaderd, werd afgesloten indien op een verpleegeenheid door 30 patiënten beide vragenlijsten waren ingevuld. Elke onderzoeksperiode duurde maximaal 2 maanden, ook indien het aantal van 30 deelnemende patiënten niet was bereikt. Bij de uitreiking van de vragenlijsten werd door de verpleging op het selektieformulier aangegeven in welke mate de patiènt in zijn/haar mobiliteit werd belemmerd (door verplichte bedrust, medikatie, infuus/apparatuur, enzovoort).

\section{De selectie van patiënten}

In Tabe】 5-1. wordt een overzicht gegeven van de selektie procedure. Het aantal patiënten dat naar de mening van de verpleegkundige leiding niet in staat werd geacht deel te kunnen nemen aan het onderzoek, is op de experimentele verpleegeenheden groter dan op de kontrole verpleegeenheden. Het is echter niet verantwoord hier vergaande konklusies aan te verbinden voor wat de representativiteit van patiënten betreft die hebben deelgenomen. Met name op kontrole verpleegeenheden vond men het een te grote belasting, om ook voor alle patiënten die niet feitelijk benaderd werden woor het onderzoek een selektieformulier in te vullen. Wel lijkt het er op dat binnen de experimentele konditie meer patiënten niet hebben meegedaan omdat de opnameduur te kort was (niet meer dan 3 dagen), terwijl op de kontrole verpleegeenheden relatief meer patiënten niet werden benaderd in verband met hun lichamelijke konditie. Het aantal patiënten dat zelf heeft aangegeven niet mee te willen doen, is op experimentele en kontrole verpleegeenheden ongeveer gelijk (respektievelijk 40 en 37).

Een deel van de patiënten vulde wel de eerste, maar niet de tweede vragenlijst in. Dit on redenen als: onverwachts ontslag; overplaatsing (naar b v. een Intensive Care afdeling); het overlijden van de patiënt; weigeren door de patiënt; de opname blijkt --tegen verwachting-- korter dan drie dagen te duren. De aantallen verschillen woor experimentele en kontrole verpleegeenheden niet noemenswaardig.

De wijze waarop patiënten op experimentele verpleegeenheden zijn geselekteerd, verschilt --voor zover we daar gegevens over hebben verzameld-m niet sterk van de wijze waarop dit op kontrole verpleegeenheden heeft plaatsgevonden. 
Tabel 5-1. Overacht van de selektie van patientem

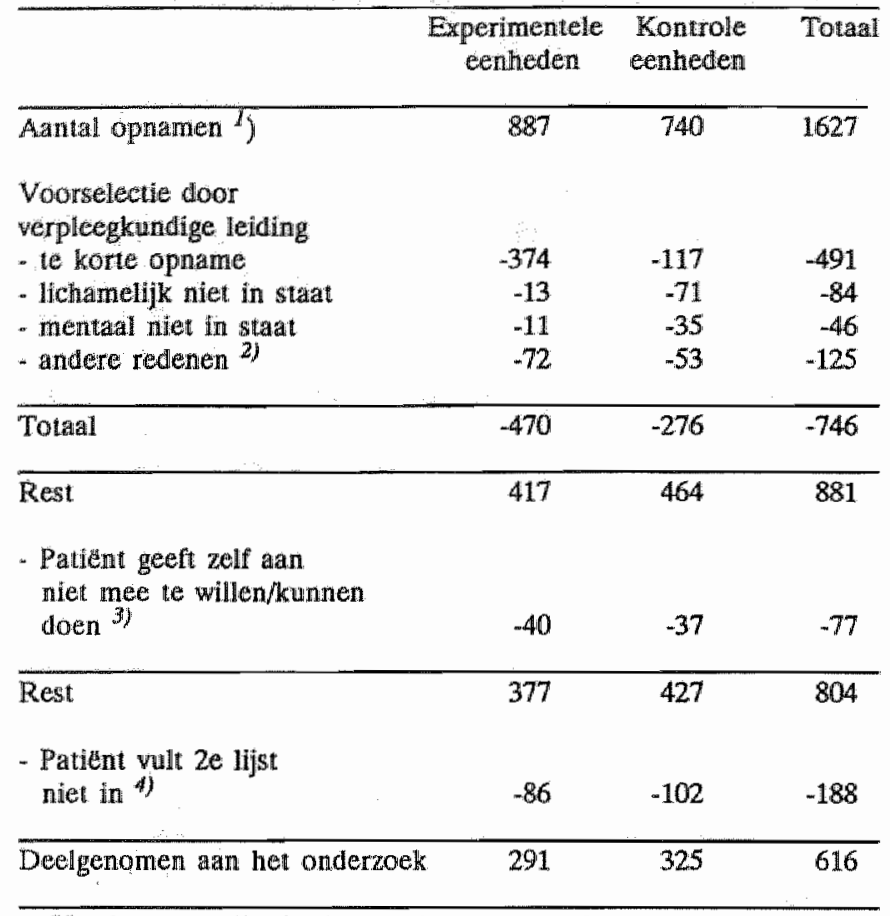

1. Het is waarschijnlijk dat het feitelijk aantal opnamen groter is dan hier aangegeven. Met name op kontrole verpleegafdelingen vond men het een te grote belasting ook voor alle patienten die niet benaderd werden voor het onderzoek een formulier in te vullen.

2. Bijvoorbeeld: kombinatie van kriteria; beheerst Nederlandse taal niet voldoende.

3. Bijvoorbeeld: kan niet lezen; geen zin; voelt zich te ziek; onbekend.

4. Bijvoorbeeld: vroegtijdig ontslag; overplaatsing naar andere verpleegeenheid; overleden.

\section{De geselecteerde patiënten}

In Tabel 5-2. worden een aantal kenmerken van de patiënten gegeven die aan het onderzoek hebben deelgenomen, uitgesplitst naar experimentele verpleegeenheden en kontrole verpleegeenheden. De gemiddelde leeftijd van patiënten van experimentele verpleegeenheden verschilt niet noemenswaardig van de gemiddelde leeftijd van patiënten wan kontrole verpleegeenheden. Hetzelfde geldt voor de gemiddelde opnameduur, het gemiddelde aantal dagen dat men in het verleden opgenomen is geweest en de mate waarin patiènten belemmerd worden in hun mobiliteit bij de tweede afname voor ontslag. Hoewel aan het onderzoek veel meer vrouwen dan mannen hebben deelgenomen en meer niet-alleenstaanden dan alleenstaanden, zijn de verschillende 
Tabel 5-2. Overzicht van enkele steekproefkenmerken, witgesplitst naar patienten die werblijven op experimentele $(n=291)$ en kontrole $(n=325)$ werpleegeenheden Nagegaan is of de waarden in de experimentele (exp) en kontrole (kontr) konditie signifikant van elkaar verschillen. De toetsresultaten worden gegeven in het rechter deel van de tabel.

\begin{tabular}{|c|c|c|c|c|c|c|c|}
\hline \multirow[b]{2}{*}{ Kenmerk } & \multirow[b]{2}{*}{$\exp$} & \multirow[b]{2}{*}{ kontr } & \multirow[b]{2}{*}{ totaal } & \multicolumn{4}{|c|}{ toets } \\
\hline & & & & natam & df & wararde & $\mathrm{p}<$ \\
\hline - Leeftijd (gemiddeld) & 44.64 & 44.51 & 44.58 & $\bar{F}$ & 1,583 & .01 & ns \\
\hline - Sexe & & & & & & & \\
\hline man & $40.0 \%$ & $33.5 \%$ & $36.6 \%$ & $x^{2}$ & 1 & 2.64 & ns \\
\hline vrouw & $60.0 \%$ & $66.5 \%$ & $63.5 \%$ & & & & \\
\hline
\end{tabular}

- Burgerlijke staat

alleenstaand:

ongehuwd, gescheiden,weduw(e)naar

nniet-alleenstaand:

gehuwd, samenwonend

$\begin{array}{ccccccc}27.0 \% & 25.9 \% & 26.4 \% & & & & \\ 73.0 \% & 74.1 \% & 73.6 \% & & & & \\ & & & & & & \end{array}$

- Oplejding

.L.O., L.B.O.

Mulo, Mavo, M.B.O.

$45.6 \% \quad 43.5 \% \quad 44.5 \%$

$\begin{array}{lllllll}29.2 \% & 32.3 \% & 30.8 \% & \mathrm{X}^{2} & 2 & .64 & \mathrm{~ns}\end{array}$

.Havo/W.W.O.,H.B.O., Universitair

$25.2 \% \quad 24.2 \% \quad 24.7 \%$

- Aantal opniames in verleden

(gemiddeld aantal keren)

$\begin{array}{lllllll}3.79 & 4.63 & 4.23 & F & 1,578 & 4.63 & .05\end{array}$

- Aantal dagen opgenomen geweest

(gemiddeld aantal dagen)

$\begin{array}{lllllll}56.85 & 69.41 & 63.45 & F & 1,559 & 1.72 & \text { us }\end{array}$

- Opnameduur (gemiddeld in dagen)

$\begin{array}{lllllll}11.75 & 12.54 & 12.17 & F & 1,540 & 1.30 & \text { ns }\end{array}$

- Belemmerd in mobiliteit

na opname (gemiddeld ) 1)

$\begin{array}{lllllll}1.45 & 1.26 & 1.35 & \text { F } & 1,549 & 7.39 & .01\end{array}$

- Belemmerd in mobiliteitt

woor ontslag (gemiddeld)

$\begin{array}{lllllll}1.30 & 1.26 & 1.28 & \mathrm{~F} & 1.540 & .66 & \mathrm{~ns}\end{array}$

1) De verpleegkundige (-leiding) heeft aangegewen of de patient geheel nilet (score 1), een beetje (score 2), nogal (score 3), sterk (score 4) of zeer sterk (score 5 ) in diens mobiliteit werd belemmerd.

groepen niet ongelijk verdeeld over de experimentele en kontrole verpleegeenheden. Ook het opleidingsnivo van patiënten verschilt niet noemenswaardig voor experimentele en kontrole verpleegeenheden. Bij de eerste meting (na opname) blijken de patiènten op experimentele verpleegeenheden meer in hun mobiliteit te worden belemmerd dan op kontrole verpleegeenheden, door bijvoorbeeld verplichte bedrust, medikatie, een infuus enz. Het aantal opnamen in het verleden ligt gemiddeld wat hoger bij patiènten 
van kontrole verpleegeenheden (gemiddeld 4.6, ten opzichte van patienten van experimentele eenheden 3.8.).

Gekonkludeerd kan worden dat patienten van experimentele verpleegeenheden en kontrole verpleegeenheden redelijk vergeljkbaar zijn op de hierboven beschreven kenmerken.

\subsection{De data-analyse}

In de vorige paragraaf is gebleken clat de patienten van de experimentele en de kontrole verpleegeenheden op een aantal kenmerken onderling redelijk vergelijkbaar zijn. Hoewel patiënten die opgenomen worden niet random toegewezen kummen worden aan de experimentele of de kontrole konditie, zijn er geen duidelijke aanwijzingen dat patiénten van kontrole en experimentele verpleegeenheden op relevante kenmerken van elkaar verschillen.

Er zijn somvariabelen gekonstrueerd door per patiënt de items behorende bij een zelfde begrip bij elkaar op te tellen en te delen door het aantal gesommeerde items. Door dit laatste kunnen somscores van verschillende (sub-)schalen met een ongelijk aantal items (met wel elk dezelfde range) onderling eventueel met elkaar vergeleken worden. Wanneer een respondent één of meerdere items behorende bij een schaal niet heeft beantwoord, kan voor die respondent geen somscore worden berekend. Aangezien in onderzoek en zeker in toegepast onderzoek, meestal nogal veel gegevens ontbreken, betekent dit een groot verlies aan informatie. Indien een respondent tot maximaal $50 \%$ van de items behorende bij een schaal niet heeft ingevuld, is voor de ontbrekende score(s) dan ook een waarde gesubstitueerd. Er kunnen globaal twee manieren onderscheiden worden om een ontbrekende score te substitueren. In de eerste plaats kan het gemiddelde ingevuld worden van de scores op het betreffende item van de overige respondenten. Een tweede methode is, om op grond van de scores van de items van de betreffende schal waarop de respondent wel een score heeft, een waarde te substitueren. Men kan het gemiddelde nemen van de scores op de vragen die een respondent wel heeft beantwoord of op grond van een regressie analyse, waarbij de wel ingevulde iterrs dienen als prediktoren, een score substitueren. Aangezien de substitutie door 'het gemiddelde van de overige items uit dezelfde schaal, aanzienlijk minder bewerkelijk is en kwalitatief niet of nauwelijks onderdoet voor de substitutie aan de hand van een regressie analyse, is voor een ontbrekende score het gemiddelde ingevuld van de niet ontbrekende scores uit de betreffende schaal (zie Ware, Brook, DaviesAvery, Williams, Stewart, Rogers, Donald \& Johnston, 1980). Patiënten die meer dan de helft van de vragen uit een schaal niet hebben beantwoord, krijgen geen score op de betreffende schaal. Het aantal observaties kan van analyse tot analyse verschillen.

\subsection{Resultaten}

In deze paragraaf wordt nagegaan in hoeverre de geformuleerde hypothesen door het verzamelde materiaal worden ondersteund. Eerst wordt echter nagegaan in hoeverre de twee hoofdkenmerken van Integrerende Verpleegkunde (in feite de 
'experimentele variabelen') daadwerkelijk op de experimentele eenheden zijn geïmplementeerd. Daarna wordt ingegaan op de algehele struktuur van het verzamelde materiaal. Dit door middel van een kanonische korrelatie tussen de kriteria en de achtergrondkenmerken (b.v. leeftijd, aantal opnamen in het verleden). Daarna worden de hypothesen getoetst.

\section{De experimentele variabelen}

In de eerste meetperiode (mei/juni 1984) werd door de verpleegkundige leiding bij elke patiënt aangegeven, of er één of meer dan eén verpleegkundige verantwoordelijk was geweest voor de verpleegkundige zorg gedurende het verblijf van de patiënt op de verpleegeenheid. Op experimentele verpleegeenheden blijkt er gedurende deze eerste meetperiode vaker één verpleegkundige verantwoordelijk te zijn geweest dan op kontrole verpleegeenheden. Op de experimentele eenheden geldt dit voor $72.2 \%$ van de patiënten en op kontrole eenheden voor $58.6 \%$ van de patiënten $\left(\mathrm{Chi}^{2}=3.86\right.$, df $=1, \mathrm{p}<.05$ ). Tijdens de tweede en derde meetperiode werd door de verpleegkundige leiding é́n vraag per patiënt beantwoord en door de patiënt vóor ontslag drie vragen. De vier vragen vormen tezamen de schaal 'patiënttoewijzing' (zie 5.1). Het blijkt dat op experimentele verpleegeenheden meer sprake is van patiënttoewijzing dan op kontrole verpleegeenheden: $F(1,365)=50.63, p<.001$. De gemiddelden bedragen voor experimentele en kontrole konditie respelktievelijk 2.94 en 2.57 (range 1 tot 4).

Naast de vragen uit de voorgaande schaal, werd aan de patiënten voor ontslag gedurende de tweede en derde meetperiode nog de volgende vraag voorgelegd (zie ook 5.1): "Wanneer u vragen over uw gezondheid heeft, wat doet u dan?". Wanneer we de antwoordmogelijkheden "ik had nooit vragen" (19\%), "ik praatte daarover met iemand anders dan een verpleegkundige" ( $1 \%$ ) en "ik praat daar helemaal niet over" (1\%) buiten beschouwing laten en kijken naar de antwoordmogelijkheden "ik ging praten met één bepaalde verpleegkundige" en "ik ging praten met een verpleegkundige die dan toevallig in de buurt was", dan blijkt dat op experimentele verpleegeenheden patiënten zich vaker wenden tot één bepaalde verpleegkundige (30\%) dan op kontrole verpleegeenheden $(12 \%)$. Op kontrole verpleegeenheden richt men zich vaker tot een verpleegkundige die in de buurt is (88\%) dan op experimentele eenheden (70\%): $\mathrm{Chi}^{2}$ $=13.07, \mathrm{df}=1, \mathrm{p}<.001$ ).

Aan de verpleegkundigen is gevraagd aan te geven voor hoeveel patienten zij gedurende een 'dagdienst' de gehele, het grootste gedeelte en een klein gedeelte van de zorg verrichten. Het blijkt dat verpleegkundigen op experimentele verpleegeenheden niet voor meer patiënten de totale zorg (zeggen te) verrichten $(\mathrm{F}[1,393]=.61$, ns), maar voor minder patiënten 'het grootste gedeelte' $(F[1,374]=10.28, \mathrm{p}<.01)$ of 'een klein gedeelte' $(\mathrm{F}[1,375]=19.05, \mathrm{p}<.001)$ van de verpleegkundige $z$ org. Het gemiddelde aantal patiënten, waarvoor het grootste gedeelte van de zorg wordt verricht bedraagt op experimentele eenheden 5.18 en op kontrole eenheden 6.54. Voor 'een klein gedeelte van de zorg' bedragen de gemiddelden respektievelijk 6.94 en 9.73 . Integrerende Verpleegkunde lijkt --inzoverre binnen dit experiment geïmplementeerd- eerder tot gevolg te hebben dat het werk van de verpleegkundigen minder versnippert, dan dat voor meer patiënten de totale zorg wordt verricht.

Tenslotte werd aan de verpleegkundige gevraagd in welke mate ze in overleg met de patiënt de zorgbehoefte, de doelstelling van de zorg en de wijze waarop deze zal 
worden uitgevoerd vaststelt, de zorg samen met de patiënt evalueert en zonodig bijstuurt. Het blijkt dat verpleegkundigen van experimentele verpleegeenheden iets meer volgens het model van het 'Systematisch Verpleegkundig Handelen' werken dan verpleegkundigen van de kontrole verpleegeenheden: $F(1,414)=4.59, \mathrm{p}<.05$. De gemiddelden bedragen respektievelijk 2.98 en 2.79 (range 1 tot 5).

Op grond van de hierboven beschreven resultaten, kan gekonkludeerd worden dat er op de experimentele verpleegeenheden meer volgens het model Integrerende Verpleegkunde wordt gewerkt dan op de niet-experimentele verpleegeenheden. Gezien de geniddelden moet wastgesteld worden dat, hoewel experimentele en kontrole verpleegeenheden op de experimentele variabelen onderling verschillen, dit niet wil zeggen dat op de experimentele verpleegeenheden optimaal volgens Integrerende Verpleegkunde wordt gewerkt en op kontrole verpleegeenheden geheel taakgericht wordt gewerkt.

\section{De situatie na opname}

Bij de bespreking van de inhoud van de vragenlijst zijn een aantal afhankelijke variabelen onderscheiden. Bij de beschrijving van de groep patiënten die aan het onderzoek heeft deelgenomen, hebben we enkele kenmerken van deze groep besproken, zoals de leeftijd en het opleidingsnivo. Om een indruk te kunnen krijgen van de relatie tussen deze kenmerken van patiënten en hun beleving van het verblijf in het ziekenhuis nadat zij zijn opgenomen, is een kanonische korrelatie berekend tussen de twee groepen variabelen. De eerste groep variabelen bestaat uit 15 afhankelijke variabelen die in paragraaf 5.1. zijn besproken. De tweede groep bestaat uit vier kenmerken van patiënten, namelijk: leeftijd, opleiding, het aantal dagen dat een patient in het verleden opgenomen is geweest in een ziekenhuis en de mate waarin de patiënt in zijn of haar mobiliteit is belemmerd door bijvoorbeeld een infuus of een werband. De eerste twee kanonische korrelaties zijn signifikant $\left(\mathrm{R}_{c l}=.57, \mathrm{p}<.001\right.$ en $\left.\mathrm{R}_{c 2}=.39, \mathrm{p}<.001\right)$. De eerste kanonische korrelatie is de maximale korrelatie tussen lineaire combinaties van de twee groepen variabelen. In Tabel 5-3 worden de korrelaties gegeven tussen de kanonische variabelen (faktoren) en de oorspronkelijke variabelen. De faktoren zijn berekend voor beide signifikante kanonische korrelaties met behulp van de gestandaardiseerde gewichten. In de eerste plaats moet vastgesteld worden dat de kanonische korrelaties niet erg hoog zijn. De eerste faktor van de eerste groep variabelen kan als volgt worden geïnterpreteerd: de mate waarin de patiënt denkt dat artsen en verpleegkundigen invloed hebben op het herstel en de gezondheid van de patiënt, het ervaren van kennisgebrek en het tonen van weinig initiatief. Op de eerste faktor van de tweede groep variabelen scoren patiënten hoog, die weinig opleiding hebben genoten, relatief oud zijn maar niet erg in hun mobiliteit zijn belemmerd door bijvoorbeeld een infuus. De eerste kanonische korrelatie kan daarmee als volgt worden geïnterpreteerd: oudere patiënten met weinig opleiding voelen zich sterker afhankelijk van artsen en verpleegkundigen. Deze patiënten vinden zich zelf minder goed geïnformeerd over hun ziekte en hun behandeling en zijn meer geneigd zelf een passieve en gelaten houding aan te nemen.

De tweede faktor uit de groep van afhankelijke variabelen, hangt samen met de verwachting van patiënten dat artsen en verpleegkundigen veel invloed hebben op het herstel en de gezondheid. De tweede faktor uit de andere groep variabelen hangt 
vooral samen met de beperkingen in de mobiliteit. Dit wijst er op dat beperkingen in de mobiliteit door bijwoorbeeld een infuus samenthangt met het zich afhankelijk voelen van zjekenhuismedewerkers.

Gezien de korrelaties uit Tabel 5-3 lijkt het er op dat oudere patiënten en patiênten die weinig opleiding hebben genoten, van mening zijn dat het herstel van de eigen gezondheid in handen is van professionele hulpverleners, waardoor deze patienten

Tabel 5-3. Korrelaties tussen kanonische variabelen en twee groepen variabelen.

De twee groepen variabelen zijn de afhankelijke variabelen "bij opname" (groep 1) en enkele kenmerken van patienten (groep 2). In de eerste kolom wordt een korte omschrijwing gegeven van de afzonderlijke variabelen. In de tweede kolom. worden de korrelaties gegeven tussen de twee kanonische variabelen berekend naar aanleiding van de eerste kanonische korrelatie (Kanvar 1) en de twee groepen variabelen $(|\mathrm{r}|>.40$ ). In de derde kolom worden de korrelaties gegeven tussen de twee kanonische variabelen berekend naar aanleiding van de tweede kanonische korrelatie (Kanwar 2) en de twee groepen variabelen $(|\mathbf{r}|>.40$ ).

\begin{tabular}{lll}
\hline Groep 1 & Kanvar 1 & Kanvar 2
\end{tabular}

Internal health locus of control

Powerful others health locus of control .73

Probleemoplossende strategieên

Ego-defensieve strategieęn

Konfronterende strategieên

Stress

Zelfzorg

Initiatief

Kennis

Invloed verpleegkundige op behandeling

Invloed verpleegkundige op verzorging

Invloed arts op behandeling

Invloed arts op verzorging

Invloed patiënt op organisatie zorg

Inwloed patiënt op psychosociale zorg

Groep 2

Kanvar 1

Kanvar 2

Mobiliteit

ILeeftijid

Opleidingsnivo

$-.81$

Dagen opgenomem geweest in verleden 
wellicht minder gebruik zullen maken van de mogelijkheden die Integrerende Verpleegkunde biedt om in de zorg te participeren. Daarnaast voelen patiënten die door praktische omstandigheden in hun mobiliteit zijn belemmerd, zich meer afhankelijk van artsen en verpleegkundigen.

\section{Toetsing wan de hypothesen}

Inwloed op de zorg. Verwacht wordt dat als gevolg van Integrerende Verpleegkunde de invloed van patienten op de zorg wordt vergroot (hypothese 1). De patiënten werd na opname en voor ontslag gevraagd naar de eigen invloed op een aantal zorgaspekten. Met behulp van een faktoranalyse konden twee dimensies worden onderscheiden. Deze dimensies werden als "organisatie van de zorg" en 'psychosociale zorg' benoemd. Nagegaan is of de reakties van patiënten wan kontrole en experimentele verpleegeenheden van elkaar verschillen.

De resultaten van deze analyse worden gegeven in Tabel 5-4. De reakties van patiënten 'na opname" en 'voor ontslag' zijn als 'binnen-proefpersonen faktor' in het ontwerp opgenomen. Het blijkt, indien geen onderscheid gemaakt wordt tussen de mening 'na opname' en 'voor ontslag', dat patiënten van experimentele en kontrole verpleegeenheden niet in verschillende mate invloed op de verzorging ervaren. We vinden met andere woorden geen significant hoofdeffekt 'konditie'. Ook blijkt dat patiënten na opname en voor ontslag geen verschil in invloed waarnemen. Wordt hierbij echter onderscheid gemaakt tussen de experimentele konditie en de kontrole konditie, dan blijkt er een significant multivariaat interaktie-effekt te bestaan van 'konditie' en 'meetmoment' (na opname/voor ontslag). Aangezien beide univariate interaktie-effekten significant zijn, kan vastgesteld worden dat er zowel verschillen bestaan ten aanzien van de gepercipieerde invloed op de 'organisatie van de zorg' als op de 'psycho-sociale zorg'. Aan de hand van de gemiddelden zoals weergegeven in Tabel 5-4, moeten de beide interaktie-effekten als volgt worden geïnterpreteerd (zie

Tabel 5-4. De door patienten ervaren invloed op de organisatie van de zorg (Org) en de psychosociale zorg (Psych), uitgesplitst voor experimentele en kontrole konditie (exp/kontr) en de mening "na opname" en "voor ontslag" (no/vo).

\begin{tabular}{|c|c|c|c|c|c|c|c|c|}
\hline \multirow[t]{2}{*}{ Bron } & \multicolumn{3}{|c|}{ Multivariaat } & \multicolumn{3}{|c|}{ Univariaat } & \multicolumn{2}{|c|}{ Gemiddelden } \\
\hline & $F$ & $\mathrm{df}$ & $p<$ & variabe & & $p<$ & $\exp$ & kontr \\
\hline Exp/Kontr & .94 & 2,325 & ns & & & & & \\
\hline no/wo & .96 & 2,325 & ns & & & & & \\
\hline \multirow[t]{6}{*}{ Exp/Kontr $x$ no/wo } & 5.65 & 2,325 & .01 & Org & 10.14 & .01 & & \\
\hline & & & & & \multirow{2}{*}{\multicolumn{2}{|c|}{$\begin{array}{l}\text { Na opname } \\
\text { Voor ontslag }\end{array}$}} & 2.23 & 2.28 \\
\hline & & & & & & & 2.45 & 2.20 \\
\hline & & & & Psych & 5.35 & .05 & & \\
\hline & & & & & \multirow{2}{*}{\multicolumn{2}{|c|}{$\begin{array}{l}\text { Na opname } \\
\text { Voor ontslap }\end{array}$}} & 3.00 & 3.01 \\
\hline & & & & & & & 3.21 & 2.96 \\
\hline
\end{tabular}


ook Figuur 5-1): Patiënten van experimentele verpleegeenheden ervaren voor ontslag meer invloed op beide zorg-dimensies, dan na opname. Zij gaan gedurende hun verblijf in het ziekenhuis meer invloed ervaren op de eigen verzorging en behandeling. Voor patiënten die opgenomen zijn op kontrole verpleegeenheden geldt dit niet. Vastgesteld kan worden dat na opname patiënten van experimentele en kontrole verpleegeenheden geen verschil in invloed ervaren, maar dat voor ontslag de patiënten van experimentele verpleegeenheden meer invloed ervaren op zowel de 'organisatie van de zorg' als de 'psychosociale zorg', omdat zij tijdens het verblijf meer invloed zijn gaan ervaren en patiënten van kontrole eenheden niet.

Het onderscheid tussen de twee zorgdimensies, dat op grond van een faktoranalyse hebben is gemaakt, is --voor wat het effekt van Integrerende Verpleegkunde op de door de patiënt gepercipieerde invloed betreft-- niet relevant. Hypothese 1 wordt bevestigd: patiënten die verpleegd worden op experimentele verpleegeenheden ervaren tijdens hun verblijf in het ziekenhuis een toename van invloed op de zorg.

\section{INVLOED VAN DE PATIENT OP DE VERZORGING}

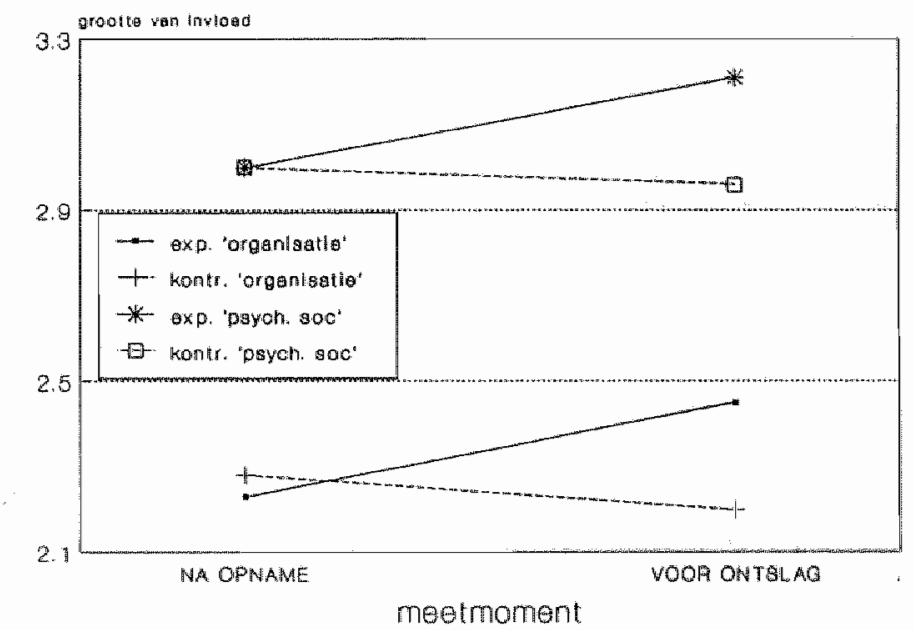

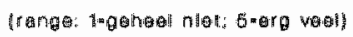

Figuur 5-1. De mate wararin patienten uit de experimentele konditie (exp) en uit de kontrole konditie (kontr), na opname en voor ontslag invloed ervaren op de organisatie van de zorg (organisatie) en op de psychosociale zorg (psych. soc).

\section{Invloed op aan de verzorging gerelateerde dimensies}

Verwacht wordt dat, wanneer patiënten die verpleegd worden op experimentele verpleegeenheden meer invloed gaan ervaren op de manier waarop zij in het ziekenhuis worden verzorgd en op het verblijf in het ziekenhuis, zij deze toegenomen 
invloed in zekere mate zullen generaliseren naar gerelateerde dimensies.

Naast vragen over de invloed van patiënten op gerelateerde onderwerpen zoals 'berstel' en 'de eigen gezondheld in het algemeen', werden ook vragen gesteld aan de patient over de invloed van artsen en verpleegkundigen op deze terreinen. Dit in navolging van Wallston en Wallston (1982), die naast een 'Internal Locus of Control' ook een 'Powerful others Lacis of Control' dimensie onderscheiden. Nagegaan is of patiènten van experimentele en kontrole eenheden onderling verschillen in de door hen gepercipieerde invloed op deze twee dimensies. De situatie 'na opname' en 'voor ontslag' is in deze analyse als 'binnen-proefpersonen faktor' opgenomen. Het blijkt dat patienten van experimentele en kontrole verpleegeenheden --ongeacht of het de situatie na opname of voor ontslag betreft-- er geen verschillende invloedsverwachtingen op na houden. Met andere woorden er is geen signifikant multivariaat hoofdeffect 'konditie' gevonden: $F(2,534)=.18$, ns. Er treden, wanneer het onderscheid tussen de kondities buiten beschouwing gelaten wordt, tijdens de opname geen veranderingen op in de door patiënt ervaren invloed van hemzelf of van artsen en verpleegkundigen op gerelateerde dimensies: $F(2,534)=1.93$, ns. Tenslotte blijkt ook het multivariate interaktie-effekt (meetmoment $x$ konditie) niet signifikant: $F(2,534)=.57$, ns. Het blijkt dat patiënten van experimentele eenheden ten opzichte van patiënten van kontrole eenheden geen hogere verwachtingen krijgen over de eigen invloed op gerelateerde gezondheidszorgaspekten. Ook wanneer uitsluitend de twee items tezamen in ogenschouw genomen worden, die het meest uitgesproken handelen over 'aan de verzorging gerelateerde onderwerpen' ("Ik kan er zelf voor zorgen dat ik sneller herstel" en "Wat goed is voor mijn gezondheid bepaal ik uiteindelijk zelf") wordt geen signifikant interaktie-effekt gevonden: $F(1,546)=.96, n s)$. Hypothese 2 wordt niet bevestigd.

\section{De overige verwachtingen}

In hypothese 3 wordt gesteld dat een door patiënten ervaren toegenomen invloed op de verzorging, tot gevolg zal hebben dat:

1. patiënten meer initiatieven gaan ontplooien in de vorm van bijvoorbeeld 'het vragen om informatie', 'het geven van de eigen mening over onderdelen van de behandeling'

2. patiënten meer zelfzorgaktiviteiten zullen gaan verrichten

3. de patiënten beter geïnformeerd raken over ziekte en behandeling

4. patiënten, doordat verpleegkundigen meer systematisch en probleemoplossend te werk gaan ('systematisch verpleegkundig handelen'), meer probleemoplossende strategieën zullen hanteren wanneer zij invloed uit willen oefenen op de zorg.

Deze vier onderdelen van hypothese 3 zijn, omdat het aantal ontbrekende gegevens per variabele nogal uiteenloopt, univariaat getoetst. De toets-resultaten over de eerste drie onderdelen worden gegeven in Tabel 5-5.

Het blijkt dat patiënten van experimentele verpleegeenheden aangeven dat zij niet meer initiatieven nemen dan patiënten van kontrole eenheden. Wel blijkt dat zowel patiènten van experimentele als kontrole eenheden gedurende hun verblijf meer initiatieven zeggen te gaan nemen: het gemiddelde na opname bedraagt 2.27 en voor ontslag 2.47. De toename verschilt echter niet signifikant voor experimentelle en 
kontrole eenheden. Op experimentele eenheden bedragen de gemiddelden respektievelijk 2.25 en 2.47 en op kontrole eenheden 2.29 en 2.45 .

Wat de door patiënten uitgevoerde zelfzorgaktiviteiten betreft blijkt -wwanneer het meetmoment buiten beschouwing gelaten wordt-- dat patiënten uit beide kondities niet in verschillende mate aangeven dat zij zelfzorgaktiviteiten verrichten. Wanneer echter onderscheid gemaakt wordt tussen de situatie 'na opname' en 'voor ontslag', dan blijkt

Tabel 5-5. De mate warin patienten angeven initiatieven te nomen, zelfarg-activiteiten te ondernemen en gemformeerd te zijn over ziekte en behandeling. Onderscheid is gemakkt ussen experimentele en kontrole verpleegeenheden (Exp/Kontr) en de mening na opnane en voor ontslag ( $\mathrm{No} / \mathrm{Vo}$ ).

\begin{tabular}{|c|c|c|c|c|c|c|}
\hline \multirow[t]{2}{*}{ Variabele } & \multirow[b]{2}{*}{ Bron } & \multicolumn{3}{|c|}{ Univariaat } & \multicolumn{2}{|c|}{ Gemidkelden } \\
\hline & & F & df & $\mathrm{p}<$ & No & Vo \\
\hline \multirow[t]{4}{*}{ Initiatieven } & $\operatorname{Exp} / \mathrm{Kontr}$ & .01 & 1,535 & ns & \multirow{4}{*}{227} & \multirow{4}{*}{2.47} \\
\hline & No/No & 47.90 & 1,535 & .001 & & \\
\hline & & & & & & \\
\hline & Exp/Kontr $\times \mathrm{No} / \mathrm{Vo}$ & 1.80 & 1,535 & ns & & \\
\hline \multirow[t]{5}{*}{$\overline{\text { Zelfzorg }}$} & Exp/Kontr & .97 & 1,549 & ns & \multirow{5}{*}{$\begin{array}{l}2.39 \\
2.41\end{array}$} & \multirow{5}{*}{$\begin{array}{l}2.50 \\
2.40\end{array}$} \\
\hline & $\mathrm{No} / \mathrm{No}$ & 2.68 & 1,549 & $\mathrm{~ns}$ & & \\
\hline & Exp/Kontr $\times \mathrm{No} / \mathrm{Vo}$ & 3.90 & 1,549 & .05 & & \\
\hline & & & & $\operatorname{Exp}$ & & \\
\hline & & & & Kontr & & \\
\hline \multirow[t]{3}{*}{ Kennis } & Exp/kontr & .87 & 1,559 & ns & \multirow[b]{3}{*}{2.80} & \multirow[b]{3}{*}{3.05} \\
\hline & Norvo & 73.83 & 1,559 & .001 & & \\
\hline & Fxn/Kontr $\times$ NoNo & 149 & 1550 & 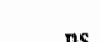 & & \\
\hline & & & & & & \\
\hline
\end{tabular}

er we wel een verschil te bestaan. De gemiddelden bedragen 'na opname' voor de experimentele en kontrole konditie respektievelijk 2.39 en 2.41 en "voor ontslag' respektievelijk 2.50 en 2.40. Vastgesteld kan worden dat patiënten van experimentele eenheden gedurende de opname naar hun zeggen meer zelfzorgaktiviteiten gaan verrichten en dat patiënten van kontrole eenheden 'voor ontslag' aangeven ongeveer nog even veel zelfzorgaktiviteiten te verrichten als 'na opname'.

Het blijkt dat patiènten in beide kondities aangeven dat zij voor ontslag ower meer kenmis beschikken wat ziekte en behandeling, betreft dan na opname. De toename van kennis is op de experimentele eenheden niet signifikant groter dan op de kontrole eenheden. De gemiddlelden in de experimentele en kontrole konditie bedragen na opname respektievelijk 2.75 en 2.84 en voor ontslag respektievelijk 3.04 en 3.06 .

Wat de door patiënten gehanteerde strategieën betreft 'wanneer zij ontevreden zijn over onderdelen van het verblijf in het ziekenhuis', is naast het gebruik van probleemoplossende strategieën ('in overleg treden met ...', 'oplossingen op een rijtje zetten') ook gekeken naar het gebruik van konfronterende strategieën (bijvoorbeeld 
"kwad worden') en ego-defensieve reakties (bijvoorbeeld 'proberen w niet aan te denkeris).

Patienten van kontrole experimentele eenheden gebruiken deze strategieen niet in werschillende mate. Het multivariate hoofdeffect "konditie" is niet signifikant: $F(3,488)$ - 19. ms. Ook het hoofdeffekt "meetmoment' is niet signifikant. Er treden tijdens het verblijf geen signifkknte veranderingen op in het gebruik van de drie strategieèn: $F(3,488)=.11$, ns. Alleen de univariate toets voor veranderingen in het gebruik van ego-defensieve strategieèn laat zien dat patiënten --ongeacht konditie- gedurende hun verblijf in hun beleving in lets minder mate defensieve strategieën gaan hanteren. "Na opname" bedraagt het gemiddelde $2.18 \mathrm{en}$ "voor ontslag" $2.12: \mathrm{F}(1,490)=4.32, \mathrm{p}<.05$. Het interaktie-effekt ("konditie $x$ meetmoment") is ook hier niet significant: $F(3,488)=$ 1.92 , ns.

We moeten konkluderen dat hypothese 3 slechts voor een klein gedeelte door het verzamelde materiaal wordt ondersteund. Patiënten van experimentele eenheden geven aan meer zelfzorgaktiviteiten te verrichten. Ten aanzien van de andere variabelen (kemnis, initiatieven en copingstrategieën) vinden we geen verschillen. Wel blijkt dat patienten in beide kondities aangeven dat zij gedurende het verblijf over meer kernis gaan beschikken, meer initiatieven gaan ontplooien en minder ego-defensief op eventuele onvrede met onderdelen van de verzorging gaan reageren. We zullen deze effekten in hoofdstuk 8 bespreken in het kader van het veronderstelde verschijnsel van aangeleerde hulpeloosheid onder ziekenhuispatienten.

\section{De invloed van de opnameduwr}

Verwacht wordt (hypothese 4) dat de opnameduur van invloed is op de mate waarin Integrerende Verpleegkunde effekten veroorzaakt bij patiënten. Naarmate de opnameduur langer is, zullen de verschillen in de afhankelijke variabelen, zoals beschreven in de eerste drie hypothesen, 'voor ontslag' tussen experimentele en kontrole verpleegeenheden groter zijn. Dit moet zich manifesteren in interaktie-effekten van 'de opnameduur' en 'de konditie'. De faktor 'konditie' is een nominale variabele en de opnameduur een variabele gemeten op ratio-niveau. Een interaktie-effekt moet blijken uit het niet parallel zijn van de regressielijnen in de twee kondities. Hierbij zijn de afthankelijke of kriterium variabelen de variabelen (genoemd in de eerste drie hypothesen) "voor ontslag" minus 'na opname" (verschilscores) "De voorspelde interakteeffekten moeten naar voren komen in sügnifikant verschillende regressiecoëfficiënten (beta-gewichten) van de covariat 'opnameduur' voor de experimentele en kontrole verpleegeenheden. Dit houdt in dat de verschilscores in de twee kondities beter voorspeld kunnen worden door een model waarin de opnameduur in de twee kondities verschillend gewogen wordt, dan in en model waarin deze in beide kondities een zelfde gewicht krijgt (zie bijvoorbeeld Winer, 1971, p. 764-775; SPSSX user's guide, 1986, p. 521-523; Cook \& Campbell, 1979, p. 155).

In Tabel 5-6 wordt de betekenis van de opnameduur als covariat in een variantieanalytisch model getoetst. Tevens wordt de verbetering van het model getoetst wanneer verschillende regressiegewichten woor de twee kondities in het model worden toegestaan (ook wel toets voor non-parallellisme genoemd). Het blijkt (Tabel 5-6) dat alleen de mate waarin patiënten voor ontslag aangeven zelfzorgaktiviteiten te verrichten, door de opnameduur verschillend voorspeld wordt in de experimentele en de kontrole konditie. 
Het (gestandaardiseerde) gewicht ( $B$-gewicht) bedraagt voor de experimentele konditie .13 en voor de kontrole konditie -.04 , zodat vastgesteld kan worden dat naarmate de opnameduur langer is, patiënten op experimentele eenheden meer zelfzorgaktiviteiten gaan verrichten en patiënten op kontrole eenheden niet. Verder blijkt dat in beide kondities, de opnameduur samenhangt met de mate waarin patiënten

1. probleemoplossend reageren wanneer ze over een aspekt van het verblijf niet tevreden zijn

2. aangeven geïnformeerd te zijn over ziekte en behandeling

3. initiatieven ontplooien.

Gelet op de regressiegewichten kan vastgesteld worden dat naarmate de opnameduur langer is, patiënten in beide kondities aangeven meer probleemoplossend te reageren $(B=.09)$, over meer kennis te beschikken $(B=.10)$ en meer initiatieven te ontplooien $(B=.12)$. In hoofdstuk 8 wordt hierop teruggekomen. Hypothese 4 vindt alleen ten aanzien van het verrichten wan zelfzorgaktiviteiten ondersteuning.

Tabel 5-6. De variabele 'opnameduur' als covariaat in enkele variantie analyses met diverse afhankelijke variabelen en met als faktor 'konditie'. In de middelste kolom word getoetst of het covariaat een signifikante bijdrage levert aan het model. In de rechter kolom wordt de toets voor non-parallellisme gegeven.

\begin{tabular}{lll}
\hline Afluankelijke wariabele & Bijdrage covariaat & Toets voor non-parallellisme \\
\hline $\begin{array}{l}\text { Invloed patiënt } \\
\text { Invloed op gerelateerde } \\
\text { onderwerpen }\end{array}$ & $\mathrm{F}(1,286)=2.82, \mathrm{~ns}$ & $\mathrm{~F}(1,285)=.87, \mathrm{~ns}$ \\
Initiatief nemen & $\mathrm{F}(1,486)=.17, \mathrm{~ns}$ & $\mathrm{~F}(1,485)=.54, \mathrm{~ns}$ \\
Probleemoplossend gedrag & $\mathrm{F}(1,462)=4.73, \mathrm{p}<.01$ & $\mathrm{~F}(1,471)=.00, \mathrm{~ns}$ \\
Zelfzorg & $\mathrm{F}(1,485)=.48, \mathrm{~ns}$ & $\mathrm{~F}(1,461)=.64, \mathrm{~ns}$ \\
Kennis & $\mathrm{F}(1,494)=7.24, \mathrm{p}<.01$ & $\mathrm{~F}(1,484)=4.01, \mathrm{p}<.05$ \\
\hline
\end{tabular}

\section{Stress en gepercipieerde invloed}

Voorspeld wordt (hypothese 5), dat patiënten die bij een opname in het ziekenhuis verwachten dat zij zelf veel invloed kunnen uitoefenen op het verblijf in het ziekenhuis, op experimentele verpleegeenheden in sterkere mate een situatie aantreffen die aan deze verwachtingen voldoet dan op kontrole verpleegeenheden. Binnen kontrole verpleegeenheden zullen patiënten naarmate hun initiële verwachtingen over de eigen invloed op de zorg hoger zijn, meer stress ervaren. Patiënten die verwachten weinig invloed uit te kunnen oefenen in het ziekenhuis en van mening zijn dat het verblijf wordt bepaald door artsen en verpleegkundigen, zullen zich konformeren aan de rolverwachtingen van artsen en verpleegkundigen. Zij zullen geen discrepantie ervaren in de mate waarin zij verwachten zelf invloed te krijgen en de mate waarin zij feitellijk inwloed ervaren. Variantie-analytisch betekent het voorgaande dat verwacht wordt dat: 
de door patiënten ervaren stress voor ontslag beter woorspeld kan worden door een model waarin "de inttielle verwachtingen over de eigen invloed" in de twee kondities een versehullend gewicht krijgt, dan met behulp van een model waarin de gewichten in beide kondities hetzelfde zijn.

Deze verwachting is getoetst met behulp wan een covariantie-analyse. De afhankelijke variabele in deze analyse is de ervaren stress voor ontslag minus de ervaren stress na opname (verschil score). Naast de faktor "konditie" (experimentele en kontrole) is als covariaat de verwachting van de patiênt over de eigen invloed op de zorg 'na opname' in het ontwerp opgenomen. Nagegaan is of na introduktie van de covariabele in het model, de covariabele voor de twee kondities afzonderlijk nog een signifikante bijdrage levert aan het voorspellen van de ervaren stress voor ontslag (toets voor nonparallellisme). Dit blijkt niet het geval : $F(1,311)=1.06$, ns. Dit betekent dat de korrelaties tussen de covariabele en de afhankelijke variabele voor de twee kondities niet signifikant van elkaar verschillen. De regressielijnen lopen met andere woorden parallel. De initiële verwachtingen over de eigen invloed zijn in de twee kondities niet verschillend gerelateerd aan de ervaren stress voor ontslag. Dit is niet in overexnstemming met de hypothese. De covariabele blijkt overigens ook ongeacht de konditie niet signifikant bij te dragen aan het verklaren van de ervaren stress voor ontslag: $\mathrm{F}(1,312)=2.55$, ns. Wel blijkt dat tijdens het verblijf patiënten in beide kondities aanzienlijk minder stress gaan ervaren: $F(1,314)=133.58, \mathrm{p}<.001$.

Hypothese 5 wordt niet ondersteund. Patiënten die bij opname verwachten dat zij invloed kunnen uitoefenen op de zorg, voelen zich niet meer op hun gemak (dat wil zeggen ze ervaren niet minder stress), op verpleegeenheden met Integrerende Verpleegkunde dan op eenheden met takgericht verplegen. Er is een secundaire analyse uitgevoerd, waarin gekeken is naar de betekenis van de door de patiënt ervaren invloed van hemzelf, de invloed van artsen en de invloed van verpleegkundigen tezamen op de verzorging en de behandeling. Deze variabele is gekonstrueerd door het sommeren van de eerder in dit hoofdstuk onderscheiden invloedswariabelen. Het blijkt clat deze somvariabele wél in de twee kondities een verschillende bijdrage levert aan het voorspellen van de door patiënten ervaren stress voor ontslag (toets voor nonparallellisme: $F(1,297)=3.92, \mathrm{p}<.05$. De regressie-coëfficiënt bedraagt voor de experimentele konditie $-.068(\mathrm{t}=-2.45, \mathrm{p}<.05)$ en voor de kontrole konditie .005 ( $\mathrm{t}$ $=.21$, ns). Dit betekent dat patiènten op experimentele verpleegeenheden naarmate zij bij opname meer invloed percipiëren van zich zelf, artsen en verpleegkundigen tezamen, zij minder stress ervaren voor ontslag. Op kontrole eenheden is deze variabele niet gerelateerd aan de ervaren stress voor ontslag. Samengevat kan worden vastgesteld dat hypothese 5 niet wordt ondersteund. Wel lijkt Integrerende Verpleegkunde meer stress te reduceren bij patiënten die bij opname van mening zijn dat het verblijf in het ziekenhuis door artsen, verpleegkundigen en hem of haar zelf, tezamen kan worden beinvloed.

\subsection{Samenvatting en diskussie.}

In deze laatste paragraaf van dit hoofdstuk worden eerst de resultaten kort samengevat en vervolgens worden enkele kanttekeningen geplaatst bij deze resultaten. In 
hoofdstuk 8 worden de resultaten gerelateerd aan het in hoofdstuk twee geschetste theoretische kader.

\section{Samenvattíng.}

Op grond van de resultaten kan gekonkludeerd worden dat slechts éen hypothese geheel door het materiaal wordt ondersteund (hypothese 1). Eén hypothese (hypothese 2) ondervindt geheel geen ondersteuning. Voor de overige hypothesen (hypothesen 3 tot en met 5) werd slechts partiële of indirekte steun gevonden.

Het blijkt dat patiënten op experimentele eenheden tijdens de opname meer invloed op de verzorging gaan ervaren (hypothese 1) en meer zelfzorgaktiviteiten gaan verrichten (hypothese 3d), terwijl dit bij patiënten van kontrole verpleegeenheden niet het geval is. Wat de zelfzorgaktiviteiten betreft wordt dit verschil tussen de twee kondities naarmate de opname langer duurt groter (onderdeel van hypothese 4).

Voor wat de overige afhankelijke variabelen betreft, zijn geen verschillen tussen de twee kondities gevonden.

In een secundaire analyse is nagegaan in welke mate patiënten vinden dat het verblijf wordt bepaald door de verpleegkundige, de arts en de patiënt tezamen. Het blijkt dat naarmate een patiënt meer 'gezamenlijke invloed' op de zorg waarneemt, er meer stressreduktie optreedt in de experimentele konditie dan in de kontrole konditie. Hiermee ondervindt hypothese 5 enige indirekte ondersteuning.

Vastgesteld kan worden dat de twee kondities --daar waar ze verschillen-- in de voorspelde richting van elkaar verschillen. De reakties van patiënten van experimentele verpleegeenheden onderscheiden zich echter slechts op enkele aspekten van de reakties wan patiënten van kontrole eenheden. Er zijn enkele mogelijke oorzaken aan te wijzen waarom de verschillen tussen de twee kondities niet groot zijn.

\section{Diskassie.}

Op grond van de reakties van patiënten en verpleegkundigen kan vastgesteld worden dat men er redelijk in geslaagd is de twee belangrijkste kenmerken van Integrerende Verpleegkunde te implementerem. De verschillen tussen de experimentele en de kontrole konditie zijn tamelijk groot voor wat het aantal verschillende verpleegkundigen betreft door wie een patiënt tijdens het verblijf in het ziekenhuis wordt verzorgd (patiënttoewijzing). Wat de mate waarin verpleegkundigen systematisch patiënten bij de planning, uitvoering en bijsturing van de zorg betrekken betreft, zijn de verschillen weliswaar statistisch signifikant, maar relatief klein. In het tweede hoofdstuk bleek op grond van elders verricht onderzoek (cf. Berry \& Metcalf, 1986), dat effekten bij patiënten vooral zijn te verwachten wanneer de participatie van patiënten systematisch door verpleegkundigen wordt gestimuleerd. Juist ten aanzien van dit aspekt zijn de verschillen tussen de twee kondities klein. Het lijkt er met andere woorden op dat de twee kondities mogelijk niet voldoende op de onafhankelijke variabele (de kenmerken van Integrerende Verpleegkunde en met name het aktief betrekken van de patiënt bij de zorg) van elkaar verschillen, hetgeen impliceert dat het onderscheidingsvermogen (de 'power') wan het onderzoek te klein geweest kan zijn.

Een andere mogelijke oorzaak van het beperkte verschil tussen de twee kondities kan gelegen zijn in het volgende. Een opname in een ziekenhuis is voor patiênten 
meestal een ingrijpende gebeurtenis. Voor een patiënt zal met name het verloop van het medisch diagnostisch onderzoek en de medische therapie van primair belang zijn. Veranderingen in de opvattingen, verwachtingen en gedragingen van patiënten zullen dan ook vooral hierdoor worden beïnvloed. Een andere verpleegkundige organisatie en werkwijze zal daardoor maar in beperkte mate aan deze veranderingen kunnen bijdragen. Aanwijzingen voor de alanwezigheid van andere faktoren, die de opvattingen, gedragingen en emoties van de patiënt beïnvloeden, worden gevonden in de vrij sterke vermindering van stress, de vergroting van de kennis over ziekte en behandeling en een toename van de door de patiënten ondernomen initiatieven gedurende het verblijf in het ziekenhuis in beide kondities.

De patiënten die aan het onderzoek hebben deelgenomen waren in het verleden gemiddeld al ruim 2 maanden in een ziekerhuis opgenomen geweest. Daarbij gelet op de gemiddeld tamelijk hoge leeftijd van patiënten (bijna 45 jaar) mag aangenomen worden dat de verwachtingen van deze patiënten over hun verblijf in het ziekenhuis, het gedrag van deze patiënten ten aanzien van de eigen gezondheid en de kognities die aan dit gedrag ten grondslag liggen, redelijk sterk zullen zijn verankerd. Naarmate verwachtingen door eigen leerervaringen meer zijn gestabiliseerd, zullen nieuwe en afwijkende ervaringen minder snel veranderingen veroorzaken in deze verwachtingen en in het gedrag. De periode waarin men ervaringen opdoet met het nieuwe verpleegkundige model is bovendien gemiddeld slechts 12 dagen.

In hoofdstuk 8 worden de zojuist genoemde beperkingen van deze studie besproken in het licht van het theoretische kader dat in het tweede hoofdstuk werd geschetst. 


\section{HOOFDSTUK 6 \\ DE VERPLEEGKUNDIGEN: MATERIAAL EN RESULTATEN}

In dit hoofdstuk worden de effekten van Integrerende Verpleegkunde voor de verpleegkundigen beschreven. Tevens zal nagegaan worden in welke mate de introduktie van het verpleegkundig model bij individuele verpleegkundigen problemen veroorzaakt en in hoeverre er binnen de verpleegeenheid mogelijkheden bestaan om deze problemen aan de orde te stellen. Alvorens de resultaten te presenteren wordt eerst de inhoud van de meetinstrumenten besproken.

\subsection{De meetinstrumenten}

Over het funktioneren van verpleegkundigen en hun positie in de organisatie werden vragen voorgelegd aan de verpleegkundigen, de verpleegkundige leiding, de artsen en aan de patiënten. De vragen die aan de patiënten werden gesteld, zijn besproken in paragraaf 5.1 (zie ook Bijlage 1). Het betreft vragen over de door hen waargenomen invloed van verpleegkundigen op de verzorging van patiënten. In deze paragraaf wordt ingegaan op de inhoud van de vragen die werden beantwoord door de andere drie groepen respondenten. Aan hen werden ook vragen gesteld over de gevolgen van de introduktie van het verpleegkundige model voor andere groeperingen in het ziekenhuis. De gevolgen voor deze andere groepen wordt besproken in het volgende hoofdstuk. Omdat de vragen over de positie van anderen in sterke mate overeenkomen met de vragen over de positie van verpleegkundigen, wordt de inhoud van deze vragen wel in deze paragraaf besproken.

$\mathrm{Na}$ de eerste observatieperiode zijn de vragenlijsten op grond van de reakties van de respondenten aangepast. Het betreft hier met name een reduktie van het aantal vragen. Ten aanzien van enkele begrippen werd de operationalisatie meer ingrijpend veranderd. De instruktie bij de wragen werd veranderd en/of de antwoordkategorieën werden naar aanleiding van de reakties van de deelnemers gewijzigd. Alleen van die operationalisaties waarbij geen enkele aanpassing heeft plaatsgevonden en/of waarbij de aanpassing uitsluitend heeft bestaan uit het verminderen van het aantal items, is het materiaal van de eerste observatieperiode in de analyse betrokken. Op de aard van de aanpassingen wordt bij de bespreking van de inhoud van de drie vragenlijsten ingegaan.

\section{De vragenlijst voor verpleegkundigen}

Gedurende de drie observatieperioden werden door 265 verschillende verpleegkundigen 435 vragenlijsten ingevuld. In de vragenlijst werden de nu volgende variabelen gemeten:

Verpleegkundige werkzaamheden. Aan de verpleegkundigen werden vragen gesteld over een zestal dimensies van de verpleegkundige beroepsuitoefening. Voor een deel zijn deze dimensies en hun operationalisaties ontleend aan een in het Academisch 
Ziekenhuis Groningen recentelijk afgerond onderzoek (Aukes et al., 1987). Het betreft de dimensies:

1. de begeleiding van patiënten, bijvoorbeeld: "Een patiënt helpen zijn ervaringen onder woorden te brengen"

2. de verpleegtechnische verrichtingen en verzorging, bijvoorbeeld: "Temperatururlijsten uitwerken"

3. de samenwerking en het overleg met kollega's en artsen, bijvoorbeeld: "Overleggen met een arts over de behandeling van een patiënt"

4. het beleid, bijwoorbeeld: "Discussiëren met kollega's over de irvulling van het beroep".

Gezien de specifieke bedoelingen van Integrerende Verpleegkunde zijn hieraan de volgende twee dimensies toegevoegd:

5. het koördineren wan de zorg, bijvoorbeeld: "Het afstemmen van de aktiviteiten van de verschillende disciplines"

6. het zelfstandig funktioneren en verantwoordelijkheid dragen, bijvoorbeeld: "De totale verpleegkundige zorg van de patiënt op je nemen".

Ten aan zien van deze dimensies werden over één of meer van de volgende aspekten vragen gesteld:

- de door verpleegkundigen ervaren onzekerheid, of ervaren onbekwaamheid ten aanzien van het uitvoeren van deze aktiviteiten (over dimensie 1, 3 en

5)

- de mate waarin de aktiviteiten door de verpleegkundige worden uitgevoerd (taakbijdrage: over dimensie $1,2,3,4$ en 6 )

- de mogelijkheden die de verpleegkundige heeft om de aktiviteiten uit te voeren (handelingsruimte: over dimensie $1,2,3,4$ en 6 )

- de mate waarin over de aktiviteiten de laatste weken met kollega's is gesproken (het plaatsvinden van interakties: over dimensie 1, 3 en 5)

- de mate waarin verpleegkundigen behoefte hebben om over de aktiviteiten met kollega's te praten (behoefte aan interakties: over dimensie 1, 3 en 5).

Uit het voorgaande blijkt dat, in overeensternming met de geformuleerde hypothesen, niet over elke taakdimensie alle vragen zijn gesteld. Wat het uitvoeren van verpleegtechnische verrichtingen bijvoorbeeld betreft, wordt niet verwacht dat verpleegkundigen hierover als gevolg van de doorgevoerde veranderingen meer onzekerheid zullen gaan ervaren. Wel wordt verwacht dat zij meer handelingsruimte zullen krijgen voor het uitvoeren van verpleegtechnische taken. In totaal zijn er 19 somvariabelen gekonstrueerd. Over de ervaren onzekerheid werden bijwoorbeeld, zoals aangegeven in het hiervoor gegeven overzicht, somvariabelen berekend ten aanzien van de ervaren onzekerheid over de begeleiding van patiënten, de ervaren onzekerheid over de samenwerking en de ervaren onzekerheid over de koördinatie van de verzorging. De betrouwbaarheidscoéfficiënten (Cronbach's alpha) variëren van .60 tot .86. Van de 19 alpha coëfficiënten zijn er 2 kleiner dan .70 .

Invloed en afhankelijkheid. De verpleegkundigen werd gevraagd aan te geven in welke mate zij bij de uitvoering van de eigen werkzaamheden rekening moeten houden met (athankelijk zijn van) een aantal kategorieën personen, namelijk: kollega's, de koördinerend hoofdverpleegkundige, de verpleegkundige leiding van de eenheid, de 
zaalarts(en), de specialist(en), de hooglera(a)r(en) en de medische registratie-assistent.

Naast deze vragen over de algemene afhankelijkheid, werden aan de verpleegkundigen ook vragen gesteld over de mate waarin zij afhankelijk zijn van vijf (groepen) personen, namelijk: de verpleegkundige leiding van de verpleegeenheid, de kollega verpleegkundigen, de zaalarts, de specialist en de patiënten. Gevraagd werd naar de afhankelijkheid ten aanzien van een achttal meer specifieke aktiviteiten. De items handelen over het inschakelen van andere medische disciplines, het inschakelen van paramedische disciplines, het inschakelen van niet-medische disciplines, het inschakelen van de huisarts na ontslag, het inschakelen van de wijkverpleegkundige na ontslag, de toewijzing van patiënten aan verpleegkundigen, het werkoverleg en het ontslag van een patiënt. De werpleegkundigen beantwoordden voor elk van deze aktiviteiten twee vragen, namelijk 'wie neemt uiteindelijk gewoonlijk de beslissing' en 'met wie wordt overlegd alvorens een beslissing wordt genomen'. De respondenten konden per item desgewenst meerdere van de hierboven genoemde vijf (groepen) personen aankruisen. Elk van deze dichotome items werd door iedere verpleegkundige tien keer beoordeeld ('wie beslist' en 'met wie wordt overlegd', voor vijf kategorieën personen). Hoewel de betrouwbaarheidscoëfficiënten (Cronbach's alpha) van deze schalen redelijk hoog zijn en op één na gelegen zijn tussen .70 en .80 , kunnen op grond van een faktoranalyse (principale komponenten analyse) over alle observaties $(2 \times 5 \times 435)$ na rotatie (Varimax) twee faktoren onderscheiden worden. De eigenwaarden van de eerste drie ongeroteerde faktoren bedragen respektievelijk 2.99, 2.01 en .81. De eerste geroteerde faktor kan benoemd worden als 'medische zorgaspecten' en de tweede faktor als 'verpleegkundige zorgaspekten'. In Bijlage IV wordt deze faktoranalyse beschreven. Aangezien het uitvoeren van een faktoranalyse over dichotome items specifieke problemen met zich mee kan brengen (zie bijvoorbeeld Ten Berge, 1972), wordt in deze bijlage ook nagegaan of deze moeilijkheden zich bij de faktoranalyse over de acht dichotome items voordoen.

De verpleegkundigen werd gevraagd aan te geven in welke mate diverse kategorieën personen invloed hebben op de algemene gang van zaken binnen de verpleegeenheid. Het betreft hier de zelfde zeven kategorieën personen waarover de 'algemene afhankelijkheidsvraag' werd gesteld. Ook werd hen gevraagd aan te geven hoeveel invloed zij zelf als individuele verpleegkundigen denken te hebben op de gang van zaken op de verpleegeenheid ('eigen invloed').

Naast deze vragen over de 'algemene invloed', werd ten aanzien van een elftal specifieke aktiviteiten gevraagd in welke mate er rekening gehouden wordt met de mening van $(=$ invloed $)$ vijf kategorieën personen. Deze kategorieën zijn: de verpleegkundige leiding, de verpleegkundigen, de zaalarts, de specialist en de patiënt. De betrouwbaarheidscoëfficiënten van de vijf groepen items varieert van .62 tot .81 (Cronbach's alpha). Ondanks de grootte van deze coëfficiënten blijkt dat er op grond van een faktoranalyse (principale komponenten analyse) na rotatie (Varimax) twee faktoren kunnen worden onderscheiden. Deze kunnen benoemd worden als: 'de invloed op verpleegkundige aangelegenheden' (faktor 1 ) en 'de invloed op meer aan de medische patiëntenzorg gerelateerde aangelegentheden' (faktor 2). In Bijlage V wordt de faktoranalyse beschreven. Daar wordt tevens de inhoud van de items gegeven.

Samengevat zijn er wat 'afhankelijkheid' en 'invloed' betreft, vragen gesteld aan de verpleegkundigen over : 
-de algemene afhankelijkheid van zeven kategorieën personen

-de afhankelijkheid van vijf kategorieên personen ten aanzien van een achttal specifieke aktiviteiten in termen van 'wie beslist" en 'met wie wordt overlegd" de invloed van zeven kategorieen personen op de algemene gang van zaken op de verpleegeenheid

-de invloed van vijf kategorieën personen op specifieke aktiviteiten -de invloed van de verpleegkundige zelf op de algemene gang van zaken op de verpleegeenheid

Kondities yoor het aangaan van interakties. In het derde hoofdstuk werden enkele kondities genoemd die van invloed zijn op de relatie tussen het ervaren van onzekerheid en de behoefte om met kollega's hierover van gedachten te wisselen. Drie van deze kondities 'sociale normen', 'waargenomen gelijkheid' en 'gevoel van eigenwaarde', werden geoperationaliseerd door respektievelijk 7,8 en 7 uitspraken, waarbij verpleegkundigen moesten aangeven in hoeverre zij het met deze stellingen eens of oneens waren. In Bijlage VI wordt de inhoud van deze 22 item gegeven. Hier volgen enkele voorbeelden.

Sociale norm:

- "Op de verpleegafdeling kan vrijuit worden gesproken over de gang van zaken".

- "Op de verpleegafdeling vindt men dat er over het algemeen te veel overlegd wordt".

Waargenomen gelijkheid:

- "Andere verpleegkundigen op de verpleegafdeling kijken op dezelfde wijze aan tegen de samenwerking met artsen als ik".

- "Wat ik moeilijk vind in de begeleiding van patiënten, wordt door andere verpleegkundigen op de verpleegafdeling ook moeilijk gevonden".

Gevoel van eigenwaarde:

- "Mijn kollega's beoordelen mijn werk meestal positief"

- "Ik denk dat kollega's graag met mij samenwerken".

De betrouwbaarheidscoëfficiënt van elk van deze drie schalen is groter dan .70. Vastgesteld moet worden dat de drie somvariabelen redelijk sterk met elkaar samenhangen. De korrelaties tussen de drie schalen liggen tussen .56 en .58. Bij een faktoranalyse (principale komponenten analyse) over de 22 uitspraken, bedragen de eigenwaarden van de eerste zes ongeroteerde faktoren respektievelijk 5.82, 1.54, 1.45, $1.24,1.07$ en .93 . De verdeling van de variantie over de eerste zes faktoren wijst eerder op én algemene onderliggende dimensie dan op drie dimensies. De eerste ongeroteerde faktor verklaart echter niet zo veel variantie (26.4\%). Van de geroteerde faktoroplossingen (Varimax-rotatie) blijkt een oplossing met twee faktoren beter te interpreteren dan een oplossing met meer faktoren. Op de tweede geroteerde faktor laden met name items waarin het eigen funktioneren of de eigen opvatting vergeleken wordt met die van kollega's of beoordeeld wordt door kollega's (gepercipieerde gelijkheid/gevoel van eigenwaarde) en op de eerste faktor de items die handelen over werkopvattingen op de verpleegeenheid (norm, klimaat, kulturur). Na eliminatie van een enkel item bedraagt de interne konsistentie (Cronbach's alpha) voor beide schalen .79 . Aan de hand van de scores op de items zijn twee somvariabelen gekonstrueerd, die we 
benoemen als 'waargenomen gelijkheid' en 'sociale norm'. In Bijlage VI wordt de faktoranalyse beschreven.

Naast de hiervoor genoemde faktoren die van invloed kunnen zijn op de mate waarin verpleegkundigen in overleg zullen tredlen met kollega's om problemen op te lossen, werd in hoofdstuk 3 tevens 'de verwerkingsstrategieën die de verpleegkundigen geneigd zijn te hanteren' als relevante variabele in deze kontext genoemd. De gebruikte schaal is afgeleid van de in hoofdstuk 3 genoemde schaal (Molleman et al., 1984). Bij een faktoranalyse (principale komponenten analyse) bedraagt de eigenwaarde van de eerste vijf ongeroteerde faktoren achtereenvolgens $2.26,1.93,1.25,1.03$, en .77 . $\mathrm{Na}$ Varimax-rotatie is de twee-faktorenoplossing goed te interpreteren. Een beschrijving van deze faktoranalyse wordt gegeven in Bijlage VII. De faktoren kunnen benoemd worden als 'probleemoplossende strategieën' (faktor 2) en 'emotie-gerichte strategieën' (faktor 1). Dit komt overeen met de door Folkman (1984) gemaakte indeling. De betrouwbaarheidscoëfficiënten (Cronbach's alpha) van beide schalen is groter dan .60.

Betrokkenheid. De mate waarin verpleegkundigen zich gebonden achten aan of zich betrokken voelen bij de innovatie is geoperationaliseerd door middel van vier items (Cronbach's alpha bedraagt .72). Een tweetal woorbeelden:

- "Wanneer kollega's geen initiatieven ontplooien ten aanzien van verpleegkundige ontwikkelingen, in hoeverre bent $U$ dan bereid hen hierover aan te spreken"?

- "Woont u ook buiten werktijd vergaderingen bij over verpleegkundige ontwikkelingen op de eigen verpleegafdeling"?

Omdat na de eerste meetperiode de labels van de antwoordkategorieën op grond van de reacties van de respondenten werden aangepast, worden de data van deze eerste meting niet in de analyse betrokken.

Statuskarakteristieken. Er zijn een achttal vragen gesteld over mogelijke relevante diffuse statuskarakteristieken. Het betreft vragen over leeftijd, sexe, funktie, het aantal maanden dat men gediplomeerd is/op de verpleegeenheid werkzaam is/de huidige funktie bekleedt, de genoten verpleegkundige opleiding en het aantal voor de beroepsuitoefening relevante vervolgopleidingen. Behalve 'sexe' en 'verpleegkundige opleiding' zijn deze karakteristieken op minimaal ordinaal nivo gemeten en hangen onderling redelijk sterk samen (Cronbach's alpha bedraagt .82). Deze schaal wordt als 'senioriteit' benoemd. De analyse van de gegevens richt zich vooral op deze diffuse status karakteristiek. Aangezien de zes items een ongelijke range hebben, zijn de scores gesommeerd na transformatie tot standaardscores ( $z$-scores).

Ten aanzien van de specifieke statuskarakteristieken, beperkt deze studie zich tot de door verpleegkundigen aangegeven eigen bekwaamheid in het begeleiden van patiënten, bekwaamheid in de samenwerking met kollega's en artsen en bekwaamheid in de koördinatie van de zorg. Bekwaamheid kan gezien worden als 'het in staat zijn de aktiviteiten uit te voeren'. De hiervoor behandelde vragen over de door verpleegkundigen ervaren onzekerheid over het wel/niet kunnen uitvoeren van de diverse werkzaamheden zijn (na spiegeling) genomen als maat voor bekwaamheid.

Beünvloedingsstrategieën. De verpleegkundigen werd gevraagd naar de door hen 
gehanteerde beirvloedingsstrategieën ten opzichte van artsen en ten opzichte van de verpleegkundige leiding. Tijdens de eerste meetperiode werd ten aanzien van het beïnvloeden van de arts onderscheid gemaakt tussen 'zaalarts' en 'specialist". Om de vragenilist te kunnen inkorten, is dit onderscheid in de tweede en derde meetperiode niet meer gemaakt. Bovendien werd de instruktie bij de vragen, naar aanleiding van de reakties van de respondenten aangepast. Terwijl in de eerste periode in de omschrijving van 'beinvloeding' de nadruk werd gelegd op 'iets van iemand gedaan krijgen' werd in de tweede en derde periode de nadruk gelegd op 'iemand ergens van overtuigen". De respondenten stoorden zich aan de eerste formulering. De data uit de eerste periode zijn niet bij de cnalyse van het materiaal betrokken.

Bij een faktoranalyse (principale komponenten analyse) bedraagt de eigenwaarde van de eerste drie ongeroteerde faktoren achtereenvolgens $3.83,1.85, .92$. In hoofdstuk 3 werd (in navolging van Veen, 1982) het onderscheid gemaakt tussen vier beïnvloedingsstrategieèn. Het lijkt gezien de verdeling van de oorspronkelijke variantie over de eerste drie ongeroteerde faktoren niet zinvol meer dan twee dimensies te onderscheiden. Een twee-faktorenoplossing verklaart meer dan de helft van de variantie en is na rotatie (Varimax) redelijk goed interpreteerbaar. In Bijlage VIII wordt de inhoud wan de items gegeven en wordt de faktoranalyse beschreven. De eerste faktor omvat konfronterende strategieên en psychologische manipulatie. De tweede faktor bevat de items die betrekking hebben op 'probleemoplossende strategieën" en beïnvloedingsstrategieën die zijn gebaseerd op het verwijzen naar regels/afspraken of het zich beroepen op deskundigheid: De tweede faktor bevat strategieën die binnen een ziekenhuisorganisatie als wenselijk en legitiem kunnen worden gezien en de eerste faktor bevat strategieën die men minder koöperatief acht. De twee faktoren vertonen overeenkomst met de faktorstruktuur die Emans (1988) vindt. Hij benoemd de faktoren respektievelijk als kompetitieve en koöperatieve beïnvloedingsstrategieën. Deze benamingen worden overgenomen. De betrouwbaarheidscoëfficiënten van elk van deze schalen bedraagt .80 (Cronbach's alpha).

\section{De vragenlijst voor artsen en de verpleegkundige leiding}

Een deel van de vragen die werden voorgelegd aan de verpleegkundige leiding en aan de artsen, betrof hun eigen houding ten aanzien van verpleegkundige ontwikkelingen en algemene vragen omtrent de invloed en de wederzijdse afhankelijkheid van diverse groeperingen. Andere vragen betroffen de mening van de verpleegkundige leiding en de artsen over de samenwerking met en het funktioneren van de verpleegkundigen. Het ligt voor de hand, dat de mening van een leidinggevende of een arts over het funktioneren van en de samenwerking met verpleegkundigen sterk van verpleegkundige tot verpleegkundige kan verschillen. Hen werd daarom gevraagd deze vragen per verpleegkundige te beantwoorden. Deze opzet bleek echter niet haalbaar. Artsen bleken veelal niet in staat uitspraken te doen over individuele verpleegkundigen, ondat zij een deel van de verpleegkundigen niet of nauwelijks (bij naam) bleken te kennen. Voor de verpleegkundige leiding bleek het beantwoorden van de vragen per verpleegkundige een zeer tijdrovende zaak. $Z$ ij moesten namelijk per verpleegkundige 35 vragen beantwoorden (de arts 23). Daarom werd besloten dat in de tweede en derde meetperiode de artsen de vragen voor het gehele verpleegkundige team zouden beantwoorden (exclusief de verpleegkundige leiding). Hen werd tevens naar een mening 
gevraagd over een verpleegkundig team van een andere verpleegeinheld. Medisch specialisten voeren over het algemeen op meer dan én verpleegeenheid werkzaamheden uit. Hen werd gevraagd een team wan een willekeurig gekozen andere verpleegeenheid te beoordelen. Zaalartsen zijn medisch specialisten in opleiding. Tijdens hun opleiding lopen ze op diverse verpleegeenheden een stage van 3 of 6 maanden. Hen werd gevraagd tevens het team van de verpleegeenheid te beoordelen waar ze direkt voorafgaand aan de huidige stage werkzaam waren geweest. De uitspraken van de artsen over individuele verpleegkundigen uit de eerste meetperiode, zijn vanwege deze veranderingen niet in de analyses betrokken.

De verpleegkundige leiding werd gevraagd niet meer alle, maar vijf verpleegkundigen te beoordelen. Aangezien verondersteld wordt --mede op grond van de ervaringen uit de eerste meetperiode-- dat 'de tijd werkzaam op de verpleegeenheid" een relevante statuskarakteristiek is, vond op grond van deze variabele stratifikatie plaats (zie bijvoorbeeld Warwick \& Lininger, 1975). Stratifikatie houdt hier in dat door de verpleegkundige leiding een rangorde werd gemaakt van de verpleegkundigen (exklusief de verpleegkundige leiding) van 'langst op de verpleegeenheid' tot 'het kortst op de verpleegeenheid werkzaam'. Er werden vervolgens vijf ongeveer even grote groepjes gevormd. Lopend van een groepje verpleegkundigen 'langst op de verpleegeenheid' tot een groepje 'kortst op de verpleegeenheid". Uit elk van de vijf groepjes werd door de onderzoekers willekeurig een verpleegkundige geselekteerd. De op deze wijze geselekteerde verpleegkundigen ('stratified random sampling') kunnen wat 'tijd op de verpleegeenheid' betreft als representatief gezien worden.

Operationalisaties bij de verpleegkundige leiding. Een deel van de vragen die aan de verpleegkundigen werd voorgelegd, zijn ook aan de verpleegkundige leiding voorgelegd. Het betreft de vragen over, $a$ de algemene afhankelijkheid van een zevental groepen personen, $b$ de algemene invloed van een zevental groepen personen, $c$ de afhankelijkheid van vijf kategorieën personen ('wie beslist' en 'met wie wordt overlegd') en $d$ de invloed van vijf kategorieën personen ten aanzien van een aantal specifieke ondlerdelen van de patiëntenzorg (zie ook Bijlage IV en V). Ook de wragen over de mate waarin de verpleegkundige leiding zich gebonden acht of betrokken voelt bij verpleegkundige innovaties, komen overeen met de vragen die door de verpleegkundigen werden beantwoord. De resterende vragen werden door de verpleegkundige leiding vijf maal beantwoord, namelijk voor elk van de vijf geselecteerde verpleegkundigen. Het betreft hier in de eerste plaats vragen over de door deze verpleegkundigen gehanteerde beïnvloedingsstrategieën tijdens interakties met leidinggevenden. De inhoud van de vragen komt overeen met de inhoud van de vragen die aan de verpleegkundigen werden voorgelegd (Bijlage VIII). De verpleegkundigen werd gevraagd aan te geven welke strategieën zij zelf hanteren, terwijl de leiding heeft aangegeven welke strategieën elk van de vijf verpleegkundigen gebruikt. Verder beoordeelde de verpleegkundige leiding deze vijf verpleegkundigen wat betreft:

a) Zelfuerzekerdheid (6 items, Cronbach's alpha is .86).

Bijvoorbeeld:

- "Durft de verpleegkundige moeilijke beslissingen te nemen?"

- "Is de verpleegkundige in staat zijn/haar mening te beargumenteren?"

b) Groepsgerichtheid (6 items, Cronbach's alpha is .89). 
Bijwoorbeeld:

- "Ondersteunt de verpleegkundige kollega's in hun werk?"

- "Stelt de verpleegkindige zich open op naar anderen?"

- Doet de verpleegkundige moeite om de sfeer op de verpleegeenheid goed te houden?"

c) Succes/evaluatie (11 items, Cronbach's alpha bedraagt .90).

Bijvoorbeeld:

- "Handelt de verpleegkundige adekwaat in moeilijke situaties?"

- "Zijn patiënten tevreden over de verpleegkundige?"

- "Hoe tevreden bent u over het verrichten van verpleegtechnische verrichtingen door de verpleegkundige?"

- "Hoe tevreden bent u over de begeleiding door de verpleegkundige van patienten?".

Opgemerkt dient te worden dat er aan de 23 items (van de onderdelen a,b en c) in feite én gemeenschappelijke dimensie ten grondslag ligt. De eigenwaarde van de eerste ongeroteerde faktor (principale komponenten analyse) bedraagt 12.16 (52,6 \% van de variantie) en van de tweede faktor 1.95. De Cronbach's alpha over deze 23 items bedraagt .96 en de korrelaties tussen de drie schalen onderling, liggen tussen .65 en .89 . Er is daarom één somvariabele 'algehele evaluatie' gekonstrueerd.

De operationalisaties bij de artsen. Over het geheel genomen waren de artsen niet erg gemotiveerd om aan het onderzoek deel te nemen. Het aantal vragen is daarom tot een minimum beperkt. Wat de vragen over de algemene afhankelijkheid en invloed van diverse kategorieën personen betreft, werden aan hen dezelffle vragen voorgelegd als aan de verpleegkundigen en de verpleegkundige leiding. Het aantal items over 'de afhankelijkheid van verschillende kategorieën personen ten aanzien van specifieke onderdelen van de zorg' ('wie beslist' en 'met wie wordt overlegd'), werd met twee gereduceerd tot acht. Het aantal items over 'de invloed van vijf kategorieën personen op specifieke onderdelen wan de patiëntenzorg' werd met vijf items gereduceerd tot zes. Het zijn items die handelen over de verpleegkundige organisatie of specifiek verpleegkundige aktiviteiten betreffen, bijvoorbeeld "De verpleegkundige werkmethode op de verpleegeenheid", "De agenda voor het verpleegkundig werkoverleg". De betrouwbaarheidscoëfficiënten (Cronbach's alpha) zijn, op één na (.61), allen groter dan .70 .

Ten aanzien van de mate waarin artsen zich betrokken voelen bij verpleegkundige innovaties, werden slechts twee vragen gesteld. Over 'de evaluatie/het succes' van het verpleegkundig team, de 'groepsgerichtheid' en de 'zelfstandigheid' werden aan de arts 12 vragen gesteld. Het betreft 12 van de 23 vragen die hierover door de verpleegkundige leiding werden beantwoord. De verpleegkundige leiding beantwoordde de vragen echter per verpleegkundige en de arts per verpleegkundig team. Uit de antwoorden van de artsen blijkt dat deze 12 items onderling hoog korreleren. Bij een faktoranalyse (principale komponenten analyse) bedraagt de eigenwaarde van de eerste ongeroteerde faktor 6.96 (57.7\% van de variantie). Ook hier is -net als bij de verpleegkundige leiding-- én variabele 'algehele evaluatie' gekonstrueerd. 


\subsection{De respondenten}

\section{De verpleegkundigen}

In Tabel 6-1 wordt een overzicht gegeven van het aantal vragenlijsten dat aan verpleegkundigen gedurende de drie meetperiodes werd nitgereikt en het aantal door hen ingevulde vragenlijsten. De aantallen zijn uitgesplitst naar experimentele en kontrole verpleegeenheden. Uit Tabel 6-1 blijkt dat in de exste meetperiode de response op de experimentele verpleegeenheden wat hoger is, dan op de kontrole verpleegeenheden. In de tweede meetperiode is de response op de kontrole verpleegeenheden iets hoger. Over het geheel genomen is de response op kontrole en experimentele verpleegeenheden gelijk (beide $74 \%$ ). In totall werden 435 wagenlijsten ingevuld, waarvan 168 door verpleegkundigen van experimentele verpleegeenheden (41\%). Een aantal verpleegkundigen vulde drie maal een vragenlijst in ( $\mathrm{n}=49$ ), een aantal tweemaal (81) en een aantal éen maal $(n=126)$. In totaal hebben daarmee 256 verschillende verpleegkundigen aan het onderzoek deelgenomen.

Tabel 6-1. Owerzicht response/non-response onder verpleegkundigen

\begin{tabular}{lcccccc}
\hline Periode & \multicolumn{2}{c}{$\begin{array}{c}\text { Experimentele eenheden } \\
\text { benaderd }\end{array}$} & \multicolumn{2}{c}{ Kontrole eenheden } & \multicolumn{2}{c}{ Total } \\
& & & & & \\
response & benaderd & response & benaderd & response \\
\hline mei/juni 1984 & 82 & $64(78 \%)$ & 103 & $67(65 \%)$ & 185 & $131(71 \%)$ \\
nov/dec 1984 & 77 & $48(62 \%)$ & 123 & $96(78 \%)$ & 200 & $144(72 \%)$ \\
mei/juni 1985 & 81 & $66(81 \%)$ & 123 & $94(76 \%)$ & 204 & $160(78 \%)$ \\
\hline Totaal & 240 & $178(74 \%)$ & 349 & $257(74 \%)$ & 589 & $435(74 \%)$
\end{tabular}

In Tabel 6-2 worden een aantal kenmerken gegeven van de verpleegkundigen die aan het onderzoek hebben deelgenomen. Het blijkt dat de verpleegkundigen van de experimentele verpleegeenheden die hebben deelgenomen aan het onderzoek op de in deze tabel genoemde kenmerken nauwelijks verschillen van de verpleegkundigen van de kontrole verpleegeenheden. Alleen de gemiddelde leeftijd van verpleegkundigen op de experimentele verpleegeenheden is hoger. Gekonkludeerd kan worden dat verpleegkundigen van experimentele en kontrole verpleegeenheden redelijk vergelijkbaar zijn op de in Tabel 6-2 genoemde kenmerken.

\section{De verpleegkundige leiding en de artsen}

In Tabel 6-3 wordt een overzicht gegeven van het aantal vragenlijsten dat door leidinggevenden en artsen werd ingevuld. Een groot aantal leidinggevenden en een kleiner aantal artsen heeft vaker een vragenlijst ingevuld. Zo hebben 25 leidinggevenden (waarvan 8 van experimentele verpleegeenheden) 57 vragenlijsten en 49 artsen (waarvan 14 van experimentele verpleegeenheden) 70 vragenlijsten ingevuld. De leidinggevenden beantwoordden een aantal vragen voor alle verpleegkundigen (eerste 
Tabel 6-2. Kenmerken van werplecgkundigen witgesplitst naar kontrolle en experimentele verpleegafdelingen

Kenmerk

1. Leeftijo (gemiddeld in faren)

2. Geslacht

- man (\%, aantal)

-vrouw (\%, atantal)

3. Tijd werkzaam op afdeling (gentiddelde in maanden)

4. Hoe lang in huidige funktie (gemiddelde in maanden)

5. Hoe lang gediplomeerd (gemiddelde in maanden)

6. Aantal gevolgde vervolgopleidingen (genilddelde)

7. Verpleegkundige opleiding*

- Inservice(aantal,\%)

- MBOV(aanta1,\%)

- HBOV(aantal,\%)

- andere(aantal,\%)

Experimentele Kontrole Total Toets af $p<$

29.12

27.20

$27.98 \quad F=8.28 \quad 1,425 \quad .05$

$13.2 \%(23) \quad 13.7 \%(34) \quad 13.5 \%(57)$

$86.8 \%(151) \quad 86.3 \%(215) \quad 86.5 \%(366) \quad X^{2}=.02 \quad 1 \quad$ ns

$\begin{array}{lllll}30.67 & 32.44 & 31.71 & F=.36 & 1.403\end{array}$

$39.88 \quad 38.21 \quad 38.89 \quad F=.33 \quad 1,405 \quad$ ns

$48.51 \quad 42.63 \quad 45.08 \quad \mathrm{~F}=3.21 \quad 1,406 \quad$ ns

$.66 \quad .61 \quad .63 \quad F=.81 \quad 1,414 \quad$ mS

$\begin{array}{rrclll}110(62.1 \%) & 163(66.3 \%) & 273(64.5 \%) & & & \\ 46(26.0 \%) & 52(21.1 \%) & 98(23.2 \%) & X^{2}=4.38 & 3 & \text { ns } \\ 20(11.3 \%) & 24(9.8 \%) & 44(10.4 \%) & & & \\ 1(0.6 \%) & 7(2.8 \%) & 8(1.9 \%) & & \end{array}$

1) Aangezien een aantal verpleegkundigen vaker dan cénmaal een vragenlijst heeft ingevuld en de kenmerken gegeven worden per vragenlijst komen dubbeltellingen voor.

Tabil 6-3. Overzicht wan het aantal door leidinggevenden en artsen ingevulde vragenlijsten, uitgesplitst naar experimentele en kontrole verpleegafdelingen en meetperiode

\begin{tabular}{|c|c|c|c|c|c|c|}
\hline \multirow[b]{2}{*}{ Meetperiode } & \multicolumn{3}{|c|}{ Leidinggevenden } & \multicolumn{3}{|c|}{ Artsen } \\
\hline & Experimentele & Kontrole & Total & Experimentele & Kontrolle & Totaal \\
\hline mei/jumi 1984 & 8 & 10 & 18 & 8 & 11 & 19 \\
\hline nov/dec 1984 & 8 & 12 & 20 & 7 & 20 & 27 \\
\hline mei/juni 1985 & 7 & 12 & 19 & 7 & 17 & 24 \\
\hline Totanl & 23 & 34 & 57 & 22 & 48 & 70 \\
\hline
\end{tabular}


meetperiode) of voor vijf verpleegkundigen (tweede en derde meetperiode). De artsen beantwoordden een aantal vragen per verpleegkundige (eerste meetperiode) of beoordeelden twee verpleegkundige teams (tweede en derde meetperiode).

\subsection{Resultaten}

In deze paragraaf worden de afzonderlijke hypothesen getoetst. Eerst wordt nagegaan of de introduktie van Integrerende Verpleegkunde gevolgen heeft gehad voor de omvang van de taken van de verpleegkundige (hypothese 1). Daarna wordt ingegaan op de machtspositie van verpleegkundigen (hypothese 2). In de derde plaats zal ingegaan worden op een aantal kondities die van belang zijn voor het versterken en behouden van een machtspositie (hypothese 3). Tenslotte wordt ingegaan op de gevolgen van taakverruiming voor individuele verpleegkundigen (hypothese 4 en 5).

\section{Handelingsruimte en taakbijdrage.}

Verwacht wordt dat de invoering van Integrerende Verpleegkunde een vergroting van het takenpakket van verpleegkundigen tot gevolg zal hebben (hypothese 1). Het gaat daarbij om taken in de samenwerking en taken op het gebied van het beleid van de verpleegeenheid. Nagegaan wordt in welke mate verpleegkundigen handelingsruimte ervaren om deze taken uit te voeren. Naast de genoemde twee taken is ook gekeken naar de mate waarin verpleegkundigen de gelegenheid krijgen om zelfstandig te werken, om patiënten te begeleiden en om verpleegtechnische taken uit te voeren. Tevens is nagegaan in welke mate verpleegkundigen een bijdrage leveren aan het uitvoeren van deze taken. De door verpleegkundigen van experimentele verpleegeenheden ervaren handelingsruimte en taakbijdrage is vergeleken met die van verpleegkundigen van kontrole eenheden. Er zijn twee multivariate toetsen uitgevoerd, namelijk een toets over de door verpleegkundigen ervaren handelingsruimte ten aanzien van vijf soorten verpleegkundige taken en een toets over de takbijdrage op deze dimensies. De toets-resultaten worden gegeven in Tabel 6-4. Het blijkt dat verpleegkundigen van experimentele eenheden meer handelingsruimte ervaren dan verpleegkundigen van kontrole eenheden. De univariate toetsen zijn signifikant voor "beleid", voor 'het zelfstandig kunnen werken' en voor het uitvoeren van verpleegtechnische verrichtingen. Ook blijkt dat verpleegkundigen uit beide kondities in hun beleving geen gelijke taakbijdrage leveren. Univariate toetsen zijn signifikant voor de bijdrage aan beleidstaken en de bijdrage aan verpleegtechnische taken. De taakbijdrage van verpleegkundigen van experimentele verpleegeenheden is, gelet op de gemiddelden die gegeven worden in Tabel 64 , in beide gevallen groter. De verschillen tussen experimentele en kontrole eenheden voor wat de handelingsruimte en de taakbijdrage betreft, worden grafisch weergegeven in Figuur 6-1. Gekonkludeerd kan worden dat over het geheel genomen verpleegkundigen van experimentele eenheden meer handelingsruimte ervaren en een grotere taakbijdrage leveren dan verpleegkundigen van kontrole verpleegeenheden. 
Tabel 64. De dror yerpleegkundigen ervaren handelingsruimte (HR) en taakbijdrage (TB) ten atanzien van ecn wijfal onderdelen van de verpleegkundige werkraamheden. Het onderscheid usisen experimentele ten kontrole verpleegeenheden is de faktor in het ontwerp.

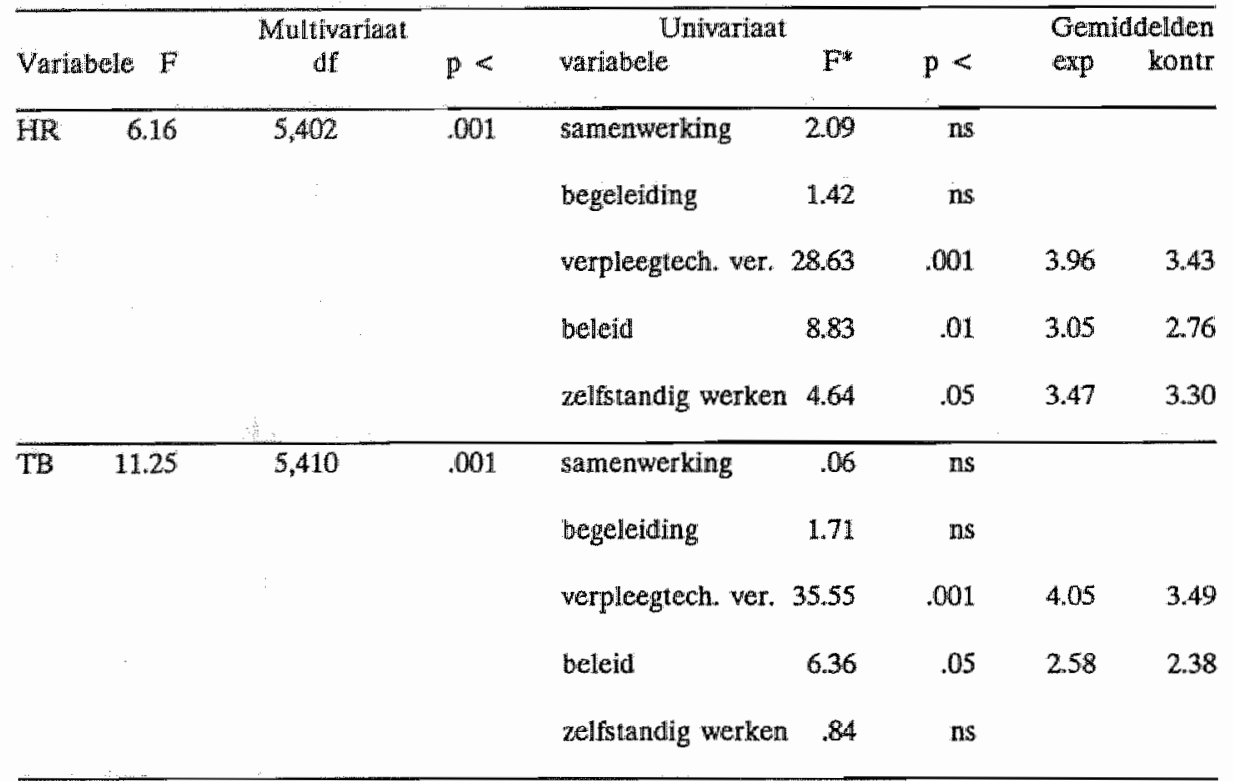

\footnotetext{
* Handelingsinuinte: $\mathrm{df}=1,406$
}

Taakbijdrage : af $=1,414$

De taakgebieden waarop verschillen optreden komen niet geheel overeen met de verwachtingen. Doordat de kommunikatie over individuele patiënten met andere disciplines niet meer door de verpleegkundige leiding wordt verzorgd, maar door de verpleegkundigen zelf, zou men op het gebied van de samenwerking een verschil in taakbijdrage verwachten tussen de twee kondities. De verschillen zijn voor "het uitvoeren van verpleegtechnische verrichtingen" opvallend groot. Verpleegkundigen van experimentele eenheden vinden dat ze aanzienlijk meer mogelijkheden hebben om verpleegtechnische verrichtingen uit te voeren (bijvoorbeeld "het bedienen van medische apparatuur'). Ze maken gezien de taakbijdrage van deze mogelijkheden ook gebruik. Gekonkludeerd kan worden dat hypothese 1 redelijk door het materiaal wordt ondersteund.

\section{De machtspositie van verpleegkundigen}

Verwacht wordt dat Integrerende Verpleegkunde leidt tot een versterking van de machtspositie van verpleegkundigen op de verpleegeenheid. Vragen werden gesteld over:

я. de invloed van de verpleegkundige discipline op de algemene gang van zaken op de eenheid

b. de invloed van verpleegkundigen op specifieke patiëntenzorgtaken (zie Bijlage V) 


\section{HANDELINGSRUIMTE EN TAAKBIJDRAGE}

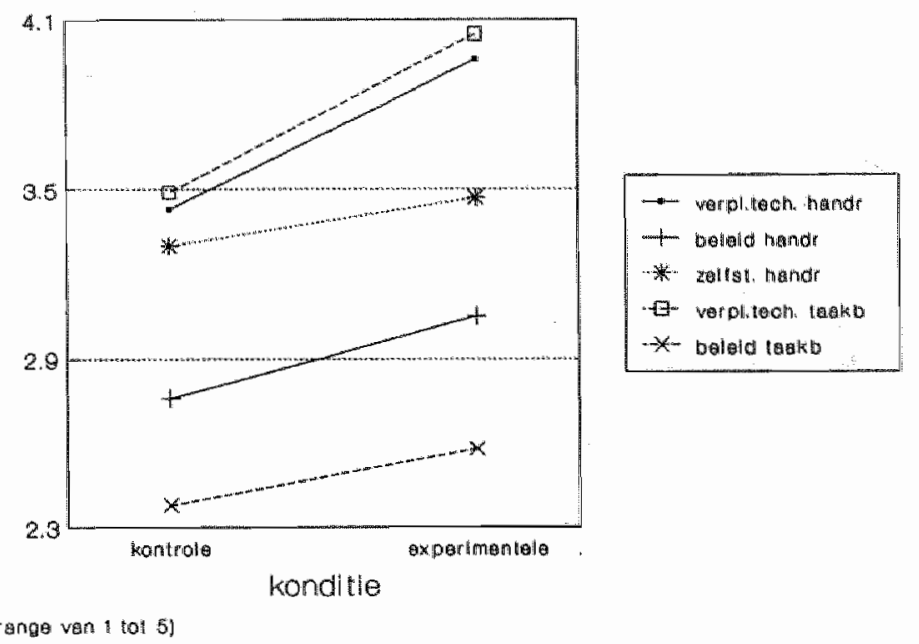

[range vara 1 tot 5 i

Figuur 6-1. De mate warin verpleegkundigen van kontrole verpleegeenheden en van experimentele verpleegeenheden:

-handelingsruimte ervaren ten aamzien van het verzorgen van patienten en het verrichten van verpleegtechnische handelingen (verpl.tech.handr), ten aanzien van het beleid (beleid handr) en ten aanzien van het zelfstandig werken (zelfst. handr)

-een bijdrage leveren aan het verzorgen van patiënten on het verrichtten van verpleegtechnische handelingen (verpl.tech.taakb) en aan het beleid (beleid taakb).

c. de mate waarin men bij het uitvoeren van taken rekening moet houden met verpleegkundigen

d. de mate waarin verpleegkundigen de uiteindelijke beslissing nemen over een aantal specifieke onderdelen van de zorgverlening (zie Bijlage IV)

e. de mate waarin met verpleegkundigen wordt overlegd alvorens over een aantal specifieke onderdelen van de patiëntenzorg beslissingen worden genomen (zie Bijlage IV)

f. de invloed van elke afzonderlijke verpleegkundige 'op de gang van zaken op de eenheid'.

De vragen onder $a$ en $c$ werden aan verpleegkundigen, de verpleegkundige leiding en artsen voorgelegd. Het onderdeel $b$ werd beantwoord door artsen, verpleegkundigen, de verpleegkundige leiding en patiënten. De operationalisaties voor verpleegkundigen en de verpleegkundige leiding zijn identiek. Bij artsen werden enkele items, die specifiek verpieegkundige zaken betreffen, weggelaten. De instruktie en de inhoud van de items voor patiënten waren afwijkend. Deze vragen werden besproken in paragraaf 5.1 (vergelijk ook Bijlage I met Bijlage V). Wat de onderdelen $d$ en $e$ betreft, werden 
vragen gesteld aan verpleegkundigen, de verpleegkundige leiding en artsen. Ook hier beantwoordden artsen enkele vragen minder. Onderdeel $f$ werd door de verpleegkundigen en de verpleegkundige leiding beantwoord.

Er zijn enkele analyses op het verzamelde materiaal uitgevoerd. Eerst worden in het kort enkele multivariate toetsen besproken. De univariate toetsen worden verderop per onderdeel ( $a$ tot en met $f$ ) besproken. In de eerste plaats is er een multivariate analyse uitgevoerd over de vragen die zowel door de verpleegkundigen, de verpleegkundige leiding en de artsen werden beantwoord. In deze analyse zijn de onderdelen $a$ tot en met zoals hierboven beschreven de afhankelijke variabelen. Naast de faktor 'konditie', is de faktor 'respondenten-kategorie' in het ontwerp opgenomen. Deze laatste faktor heeft drie niwo's, namelijk 'verpleegkundigen', 'de verpleegkundige leiding' en 'artsen'. De resultaten van deze analyse worden gegeven in Tabel 6-5. Er blijken twee signifikante hoofdeffekten te bestaan. Het hoofdeffekt "konditie' geeft aan dat de oordelen van de respondenten van de experimentele en de kontrole verpleegeenheden over de positie van verpleegkundigen op de verpleegeenheid van elkaar verschillen. Het hoofdeffekt 'respondent' laat zien dat de drie groepen respondenten de positie van verpleegkundigen in beide kondities verschillend beoordelen. Verder blijkt dat naast deze twee hoofdeffekten ook het multivariate interaktie-effekt signifikant is. Voor de interpretatie van deze multivariate effekten worden de diverse signifikante univariate toetsen afzonderlijk bekeken.

In de tweede plaats is er een multivariate analyse uitgevoerd over de vragen die zijn beantwoord door de verpleegkundigen en de verpleegkundige leiding. Het betreft vragen over de onderdelen $b, d$ en $e$, inklusief de vragen die niet door de artsen werden beantwoord. Op grond van een faktoranalyse konden bij deze drie onderdelen twee teakdimensies onderscheiden worden (zie bijlage IV en V), namelijk specifiek verpleegkundige aangelegenheden en de meer medische zorgaspecten. De multivariate analyse is dan ook uitgevoerd over zes afhankelijke variabelen. Naast de faktor 'konditie' is er een faktor 'respondenten groep' in het ontwerp opgenomen, met twee nivo's namelijk 'de verpleegkundigen' en de 'verpleegkundige leiding'. De resultaten van de analyse worden gegeven in Tabel 6-6. Er is een signifikant multivariaat hoofdeffekt 'konditie'. Op experimentele en kontrole verpleegeenheden wordt door de respondenten verschillend gedacht over de invloedspositie van verpleegkundigen. Tevens wordt een multivariaat interaktie-effekt gevonden, hetgeen wil zeggen dat de verpleegkundigen en de leidinggevenden de verschillen in invloedspositie van verpleegkundigen uit de experimentele en uit de kontrole konditie niet hetzelfde waarnemen. De univariate toetsen worden werderop besproken.

In de derde plaats is een multivariate analyse uitgevoerd over de mening van patienten aangaande de invloed van verpleegkundigen op de verzorging/begeleiding en de behandeling (Tabel 6-7). Bij de bespreking van de invloed van verpleegkundigen op specifieke patiëntenzorgtaken, wordt nader op deze toets ingegaan. In de vierde plaats is er een univariate toets uitgevoerd ten aanzien van de invloed van individuele verpleegkundigen op de algemene gang van zaken op de verpleegeenheid (onderdeel $f$, zoals beoordeeld door de verpleegkundige en de leidinggevende (Tabel 6-8). 
Tabel 6-5. De invloedspositie van verpleegkundigen. Deze werd gemeten aan de hand wan $a_{3}$ de algemene invloed van de verpleegkundige discipline (alginw) b. de invloed op specifieke aspecten (specinwl) $c$ de algemene afhankelijkheid (algafh) $d$. het nemen van beslissingen (beslissen) $e$. het betrokken worden bij overleg (owerleg). Als faktoren in in het ontwerp opgenomen 1 . de twee kondities ( $\exp /$ kontr) en 2 . de drie groepen respondenten (resp), artsen verpleegkundigen en de verpleegkundige leiding (vk, vkleid,arts).

\begin{tabular}{|c|c|c|c|c|c|c|c|c|c|}
\hline \multirow[t]{2}{*}{ Bron } & \multicolumn{3}{|c|}{ Multiwariaat } & \multicolumn{3}{|c|}{ Univariaa } & \multicolumn{3}{|c|}{ Gemiddelden } \\
\hline & $\mathrm{F}$ & df & $p<$ & variabele & $\mathrm{F}$ & $p<$ & & $\mathrm{p}$ & kontr \\
\hline \multicolumn{10}{|c|}{ exp/kontr } \\
\hline & \multirow[t]{6}{*}{14.87} & \multirow[t]{6}{*}{5,486} & \multirow[t]{6}{*}{.001} & alg.inw1 & 3.00 & ins & \multirow{2}{*}{\multicolumn{2}{|c|}{292}} & \\
\hline & & & & specinv & 17.97 & .01 & & & 2.74 \\
\hline & & & & alg.afh & 5.05 & .05 & \multicolumn{2}{|c|}{3.65} & 3.82 \\
\hline & & & & beslissen & 42.62 & .001 & \multicolumn{2}{|c|}{.43} & .28 \\
\hline & & & & owerleg & 45.27 & .001 & \multicolumn{2}{|c|}{.63} & .45 \\
\hline & & & & & & & \multicolumn{2}{|c|}{ vk wkleid } & arts \\
\hline \multirow[t]{5}{*}{ resp } & 6.45 & 10,972 & .001 & alg.invl & .23 & $\mathrm{~ns}$ & & & \\
\hline & & & & spec.inv & 18.36 & .001 & 2.82 & 3.06 & 2.54 \\
\hline & & & & alg.afh & 10.16 & .001 & 3.74 & 4.14 & 3.47 \\
\hline & & & & beslissen & 11.54 & .001 & .37 & .35 & .18 \\
\hline & & & & overleg & 13.19 & .001 & .55 & .58 & .33 \\
\hline \multicolumn{10}{|c|}{ exp/kontr $x$ resp } \\
\hline & 3.09 & 10,972 & .001 & alg.invl & 1.17 & $\mathrm{~ns}$ & & & \\
\hline & & & & specinvl & 203 & ns & & & \\
\hline & & & & alg.afh & 5.60 & .01 & & & \\
\hline & & & & & & exp: & 3.55 & 4.30 & 3.67 \\
\hline & & & & & & kontr: & 3.89 & 4.03 & 3.38 \\
\hline & & & & beslissen & 1.30 & ns & & & \\
\hline & & & & overleg & 5.16 & .01 & & & \\
\hline & & & & & & exp: & .63 & .82 & .47 \\
\hline & & & & & & kontr: & .49 & .41 & .27 \\
\hline
\end{tabular}

* Het aantal vrijheidsgraden bedraagt woor de univariate effekten "konditie" 1,490 en voor de overige univariate toetsen 2,490

De invloed op de algemene gang van zaken. Wat de invloed op de algemene gang van zaken binnen de verpleegeenheid betreft, worden geen univariate signifikante effekten gevonden (Tabel 6-5). Er bestaat alleen een tendens ( $p<.10$ ), dat de invloed van verpleegkundigen op experimentele eenheden (gemiddeld 3.71) hoger ingeschat wordt dan de invloed van verpleegkundigen op kontrole eenheden (gemiddelde 3.56).

Invloed op specifieke taken. Ten aanzien van de invloed op specifieke patiëntenzorgaangelegenheden, zoals beoordeeld door verpleegkundigen, hun leidinggevenden en artsen zijn de twee univariate hoofdeffekten signifikant. Het hoofdeffekt 'konditie' houdt gezien de gemiddelden (Tabel 6-5) in, dat de drie groepen respondenten van experimentele eenheden de invloed van verpleegkundigen groter vinden dan de respondenten van kontrole eenheden. Het hoofdeffekt 'respondentengroep', kan aan de hand van de kontrasten geïnterpreteerd worden als: de leiding vindt de invloed van. 
Tabel 6.6. De invloedspositie van verpleegkundigen in termen van $a$. invloed op de verpleegkundige zorgaspecten (inw $v \mathrm{kz}$ ) $b$. invloed op de medische zorgaspecten (invlmedz) $c$. kunnen beslissen over de werpleegkundige zorg (beslis.vkz) $d$. kunmen beslissen over de medische zorg (besils.meda) e. bij overleg betrokken worden ten aanzien van verpleegkundige zorg (overteg why) $f$. bij overleg betrokken worden ten aanzien wan de medische zorg (overleg.medz). Als faktoren zijn in hiet ontwerp opgenomen 1 . de twee kondities(exp/kontr) en 2 twee respondentengroepen (resp): verpleegkundigen (vk) en de verpleegkundige leiding (vkleid).

\begin{tabular}{|c|c|c|c|c|c|c|c|c|}
\hline \multirow[t]{2}{*}{ Bron } & & \multicolumn{2}{|c|}{ Multivariaat } & \multicolumn{2}{|c|}{ Univariast } & \multirow[b]{2}{*}{$\mathrm{p}<$} & \multicolumn{2}{|c|}{ Gemiddelden } \\
\hline & F & df & $\mathrm{p}<$ & wariabele & $F(1,433)$ & & $\exp$ & kontr \\
\hline \multirow[t]{6}{*}{ exp/kontr } & 10.74 & 6,428 & .001 & InvLvkz & 5.27 & .05 & 4.07 & 3.92 \\
\hline & & & & invl.medz & 3.10 & ns & & \\
\hline & & & & beslis.vkz & 40.78 & .001 & .70 & .50 \\
\hline & & & & beslis.medz & 9.53 & .01 & .25 & .17 \\
\hline & & & & overleg.vkz & 21.36 & .001 & .78 & .65 \\
\hline & & & & overleg.medz & 35.30 & .001 & .59 & .40 \\
\hline resp & 1.84 & 6,428 & ns & & & & & \\
\hline \multicolumn{9}{|c|}{ exp/kontr $x$ resp } \\
\hline & 2.24 & 6,428 & .05 & invl.vez & .36 & ns & & \\
\hline & & & & invimedz & 3.01 & ns & & \\
\hline & & & & beslis.vkz & 2.01 & ns & & \\
\hline & & & & beslis.medz & 1.66 & $\mathrm{~ns}$ & & \\
\hline & & & & overleg.vkz & 7.94 & .01 & & \\
\hline & & & & & & vk & .76 & .66 \\
\hline & & & & & & vkleid & .95 & .61 \\
\hline & & & & overleg.medz & 10.40 & .01 & & \\
\hline & & & & & & $\mathrm{vk}$ & .57 & .42 \\
\hline & & & & & & vkleid & .76 & .31 \\
\hline
\end{tabular}

Tabel 6-7. De door patienten gepercipieerde invloed vam verpleegkundigen op a. de verzorgende en begeleidende taken (werz) en $b$. aspecten rond de behandeling (beh). Naast de faktor 'konditie' (exp/kontr), is de mening van patienten 'na opname' en 'voor ontslag' als binmensubjekten-faktor in het ontwerp opgenomen (nofvo).

\begin{tabular}{|c|c|c|c|c|c|c|c|c|}
\hline \multirow[b]{2}{*}{ Bron } & \multicolumn{3}{|c|}{ Multivariaat } & \multicolumn{3}{|c|}{ Univariaat } & \multicolumn{2}{|c|}{ Gemiddelden } \\
\hline & $F$ & df. & $p<$ & wariabele & $\mathrm{F}(1,345)$ & $\mathrm{p}<$ & $\exp$ & kontr \\
\hline \multirow[t]{2}{*}{ Konditie } & 2.54 & 2,344 & $\mathrm{~ns}(.09)$ & verz & .96 & $\overline{n s}$ & & \\
\hline & & & & beh & 5.09 & .05 & 2.56 & 2.37 \\
\hline no/vo & .99 & 2,344 & nIS & & & & & \\
\hline \multirow[t]{4}{*}{ Kond $x$ no/wó } & 2.70 & 2,344 & $\mathrm{~ns}(.07)$ & verz & .33 & & & \\
\hline & & & & beh & 4.83 & .05 & & \\
\hline & & & & & & no & 2.51 & 2.44 \\
\hline & & & & & & vo & 260 & 2.30 \\
\hline
\end{tabular}


verpleegkundigen groter dan verpleegkundigen zelf $(\mathrm{p}<.01)$. Verpleegkundigen vindem op hun beurt meer dan artsen dat verpleegkundigen invloed hebben op de zorg $(\mathrm{p}<$ $.05)$.

Wanneer alleen de reakties van de verpleegkundigen en de verpleegkundige leiding bekeken worden en daarbij onderscheid gemaakt wordt tussen de twee zorgdimensies, dan blijkt er voor één van deze twee dimensies een univariaat hoofdeffekt 'konditie' te zijn, namelijk voor de 'invloed op de verpleegkundige zorgaspekten' (Tabel 6-6). Gezien de gemiddelden moet vastgesteld worden dat beide groepen respondenten de invloed van verpleegkundigen op de verpleegkundige zorg op experimentele verpleegeenheden hoger inschatten dan op kontrole eenheden.

De patiënten beoordeelden --zoals in paragraaf 5.1. werd beschreven-- na opname en voor ontslag niet alleen de eigen invloed op een aantal specifieke zorgaspekten, maar ook de invloed van verpleegkundigen op deze zorgaspekten. Op grond van een faktoranalyse (Bijlage I) bleek dat er onderscheid gemaakt kan worden in twee zorgdimensies namelijk 'verzorgende en begeleidende taken' en 'aspekten rond de behandeling'. Met behulp van een variantie-analyse zijn de reakties van patiënten geanalyseerd (Tabel 6-7). De situatie 'na opname/voor ontslag' is als ('een binnensubjekten') faktor in de analyse opgenomen. Daarnaast is de 'konditie' als faktor in het ontwerp opgenomen. Er worden geen signifikante multivariate effekten gevonden. Wel is er een tendens dat patiënten van experimentele eenheden meer dan patiënten van kontrole eenheden vinden dat verpleegkundigen invloed hebben op aspecten rond de behandeling. Tevens is er een tendens dat patiënten op experimentele eenheden gedurende de opname een toename van de invloed van verpleegkundigen ervaren terwijil patiënten van kontrole eenheden eerder een afname ervaren.

Tabel 6-8. De invloed van individuele verpleegkundigen op de algemene gang van zaken op de eenheid. Als faktoren zijn in het ontwerp opgenomen $\not$. konditie (exp/kontr) en 2 twee groepen respondenten (resp): verpleegkundigen (vk) en de verpleegkundige leiding (vkleid).

\begin{tabular}{lrrrrrr}
\hline Bron & F & df & p $<$ & \multicolumn{2}{c}{ gemiddelden } \\
& & & & exp & kontr \\
\hline exp/kontr & 5.38 & 1,925 & .05 & 2.84 & 2.69 \\
& & & & & wk & vkleid \\
resp & 84.77 & 1,925 & .001 & $\overline{2.43}$ & $\frac{3.02}{3.45}$ \\
$\exp /$ kontr x resp & .07 & 1,925 & ns & & \\
\hline
\end{tabular}

Algemene afhankelijkheid. De verpleegkundigen, de leidinggevenden en de artsen werd gevraagd in hoeverre zij bij het uitvoeren van de eigen werkzaamheden rekening moeten houden met de wensen en aktiviteiten van verpleegkundigen. Er worden twee 
signifikante univariate hoofdeffekten en een signifikant interaktie-effekt gevonden (Tabel 6-5). Het hoofdeffekt "konditie' laat weliswaar zien dat respondenten van kontrole eenheden zich in hun werkzaamheden afhankelijker voelen van verpleegkundigen dan respondenten van experimentele eenheden (gemiddelden respektievelijk 3.82 en 3.65 ), maar het interaktie-effekt geeft aan dat dit voor de drie groepen respondenten verschillend ligt. Het blijkt dat voor de verpleegkundigen geldt dat op experimentele eenheden zij zich minder afhankelijk voelen van kollega's in vergelijking tot verpleegkundigen van kontrole eenheden $(\mathrm{p}<.001)$. Ten aanzien van de verpleegkundige leidung en de artsen worden geen signifikante verschillen gevonden. De gemiddelden suggereren eerder dat zij zich op experimentele eenheden meer afhankelijk voelen van verpleegkundigen dan op kontrole verpleegeenheden (zie Figuur 6-2).

Het hoofdeffekt 'respondentengrcep' laat zien dat de verpleegkundige leiding zich bij het uitvoeren van haar taak afhankelijker voelt wan verpleegkundigen dan verpleegkundigen zich in het werk afhankelijk voelen van kollega's $(p<.001)$. Verpleegkundigen en artsen verschillen hierover onderling niet erg sterk van mening.

\section{AFHANKELIJK VAN VERPLEEGKUNDIGEN}

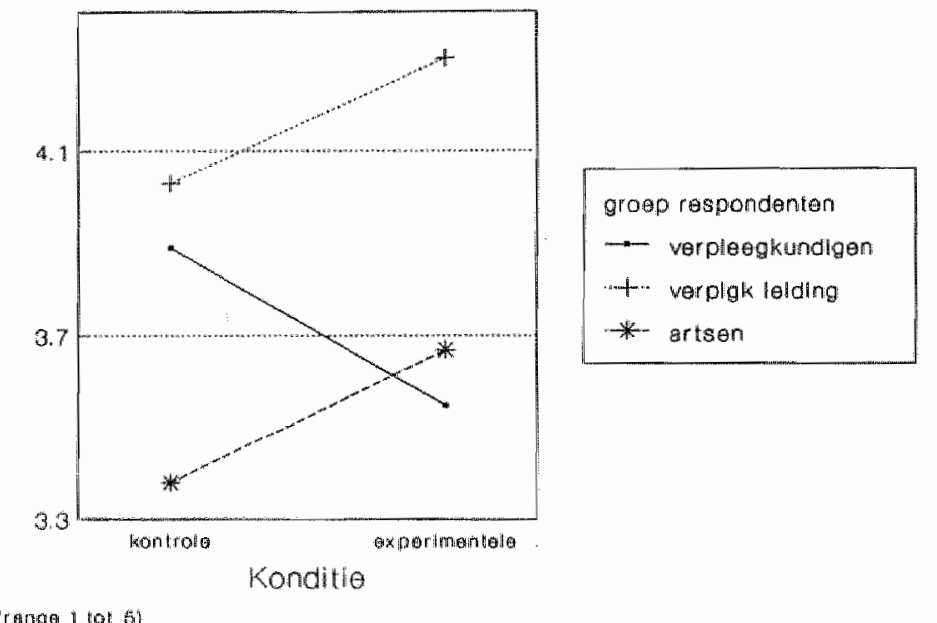

Irange i tor bi

Figuur 6-2. De mate waarin verpleegkundigen, de verpleegkundige leiding (verplgk. leiking) en artsen uit de kontrole en uit de experimentele konditie zich bij het verrichten van hun werkzaamheden afhankelijk voelen van verpleegkundigen.

Het nemen van beslissingen. Ten aanzien van de mate waarin verpleegkundigen zelfstandig beslissingen kunnen nemen rondom werkzaamheden in de patiëntenzorg, 
worden twee signifikante hoofdeffekten gevonden (Tabel 6-5). Het hoofdeffekt 'konditie' laat zien dat volgens de drie groepen respondenten, de verpleegkundigen van experimentele eenheden aanzienlijk meer zelfstandig kunnen beslissen dan verpleegkundigen van kontrole eenheden. Het hoofdeffekt 'respondentenkategorie' geeft aan dat verpleegkundigen en leidinggevenden onderling niet van mening verschillen over dit onderwerp maar beide meer dan artsen vinden, dat verpleegkundigen zelfstandig beslissingen kunnen nemen $(p<.001)$.

Bekijken we de reakties van de verpleegkundigen en de leidinggevenden en maken we daarbij onderscheid in het nemen van beslissingen in de verpleegkundige zorg en het nemen van beslissingen in de medische zorg, dan vinden we twee hoofdeffekten (Tabel 6-6). Deze hoofdeffekten moeten gezien de gemiddelden als volgt geïnterpreteerd worden: verpleegkundigen van experimentele eenheden kunnen in grotere mate zelfstandig beslissingen nemen dan verpleegkundigen van kontrole eenheden. Het verschil is het grootste ten aanzien van specifiek verpleegkundige aangelegenheden.

Bij overleg betrokken worden. Het blijkt (Tabel 6-5) dat beide univariate hoofdeffekten en het interaktie-effekt signifikant zijn. Het hoofdeffekt 'konditie' geeft aan dat de respondenten van experimentele eenheden, in sterkere mate dan respondenten van kontrole eenheden vinden dat met verpleegkundigen wordt overlegd alvorens een beslissing genomen wordt over onderdelen van de patiëntenzorg. Naar aanleiding van het interaktie-effekt zijn de verschillen tussen de twee kondities per respondentengroep getoetst ('simple main' effekten). Het bljikt dat het zojuist besproken hoofdeffekt 'konditie' weliswaar voor elk van de drie groepen respondenten geldt, maar bij de ene groep respondenten aanzienlijk sterker is dan bij de andere groep respondenten (zie de gemiddelden in Tabel 6-5). De verpleegkundige leiding van experimentele en kontrole eenheden verschillen onderling het sterkst van mening $(\mathrm{p}<.001)$. Ook verpleegkundigen van experimentele en kontrole eenheden verschillen onderling sterk van mening $(\mathrm{p}<.001)$. Artsen wan experimentele en kontrole eenheden verschillen onderling wel van mening, maar minder sterk dan dat de leidinggevenden uit de twee kondities onderling van opvatting verschillen $(\mathrm{p}<.05$; zie Figuur 6.3).

Ongeacht konditie vinden artsen dat zij in mindere mate overleg behoeven te plegen met verpleegkundigen voordat zij beslissingen kunnen nemen, dan dat verpleegkundigen van mening zijn dat zij dat behoren te doen $(p<.001)$. De verpleegkundigen en de verpleegkundige leiding verschillen hierover niet van mening.

Indien uitsluitend gekeken wordt naar de reakties van verpleegkundigen en leidinggevenden en daarbij onderscheid gemaakt wordt tussen de twee taakdimensies (Tabel 6-6), dan blijkt dat de respondenten van experimentele eenheden sterker dan de respondenten van kontrole eenheden vinden dat verpleegkundigen bij overleg ten aanzien van beide zorgdimensies betrokken worden. Zowel verpleegkundigen als leidinggevenden van experimentele eenheden vinden, sterker dan verpleegkundigen en leidinggevenden van kontrole verpleegeenheden, dat verpleegkundigen meer bij overleg worden betrokken. De twee interaktie-effekten laten echter zien, dat op experimentele eenheden leidinggevenden meer dan verpleegkundigen vinden dat verpleegkundigen bij overleg rondom beide soorten taken worden betrokken (ten aanzien van beide dimensies, $p<.001$ ) terwijl dit op kontrole eenheden niet het geval is. Leidinggevenden van experimentele en kontrole eenheden verschillen met andere woorden onderling 
sterker van mening dan de verpleegkundigen uit de twee kondities.

\section{MATE WAARIN VERPLEEGKUNDIGEN BIJ OVERLEG BETROKKEN WORDEN}

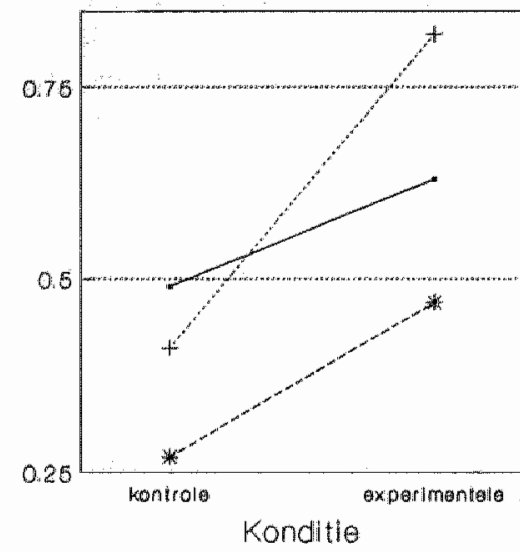

GROEP RESPONDENTEN

varplengundigen

matum varplgk leiding

- * artisen

(range van o tot 1)

Fuguur 6.3. De mate waarin werpleegkundigen, de verpleegkundige leiding (verplgk. leiding) en artsen uit de kontrole en uit de experimentele konditie overleg moeten plegen met verpleegkundigen, alvorens zij beslissingen kunnen nemen.

Invloed van individuele verpleegkundigen. Als laatste operationalisatie van de machtspositie van verpleegkundigen in de organisatie, is door elke verpleegkundige aangegeven hoeveel invloed hij of zij zelf denkt te hebben op de algemene gang van zaken $(\mathrm{n}=420)$. Ook de leidinggevenden hebben de invloed van afzonderlijke verpleegkundigen op de gang van zaken beoordeeld $(n=509)$. Er is een analyse met twee faktoren uitgevoerd, namelijk een faktor "konditie' en een faktor 'respondentengroep": De resultaten worden gegeven in Tabel 6-8. Er worden twee signifikante hoofdeffekten gevonden. Het hoofdeffekt 'konditie' geeft aan dat de respondenten van experimentele eenheden ten opzichte van respondenten van kontrole eenheden de invloed van verpleegkundigen groter vinden. Het hoofdeffekt 'respondentengroep' geeft aan, dat hoofdverpleegkundigen de invloed van verpleegkundigen --ongeacht konditie-hoger inschatten dan verpleegkundigen zelf.

Samengevat. Vastgesteld kan worden dat uit de analyses blijkt, dat hypothese 2 overwegend wordt ondersteund door het verzamelde materiaal. Bij twee variabelen 
wordt een tendens in de voorspelde richting gevonden, namelijk ten aanzien van de invloed van verpleegkundigen op de algemene gang van zaken en de door de patient waargenomen invloed van werpleegkundigen. Ten aanzien van de overige variabelen blijken er signifikante verschillen tussen de twee kondities in de voorspelde richting te bestaan. Zowel verpleegkundigen, de verpleegkundige leiding als artsen vinden dat de verpleegkundigen op experimentele verpleegeenheden meer invloed hebben op de patiëntenzorg dan verpleegkundigen op kontrole verpleegeenheden. Tevens worden verpleegkundigen op experimentele verpleegeenheden meer bij overleg betrokken en kunnen zij meer zelfstandig beslissingen nemen in hun werk. Bovendien voelen verpleegkundigen van experimentele eenheden zich minder afhankelijk van kollege's dan verpleegkundigen van kontrole eenheden. Hoewel bij alle drie groepen respondenten de genoemde verschillen gevonden worden, lijken de meningen van de leidinggevenden van kontrole en experimentele eenheden het sterkst van eikaar te verschillen. De positie van verpleegkundigen wordt overigens in beide kondities over het algemeen door de leidinggevenden het sterkst gevonden en door de artsen het minst sterk. Het onderscheid tussen de invloed op 'specifiek verpleegkundige aangelegenheden' en de invloed op meer 'medische aspekten in de zorg', is ten aanzien van de verschillen tussen experimentele en kontrole konditie niet erg relevant gebleken. Gekonkludeerd kan worden dat hypothese 2 door het verzamelde materiaal wordt ondersteund.

\section{Kondities voor de versterking van de machtspositie}

In hypothese 3 (paragraaf 3.1) wordt voorspeld dat de machtspositie van verpleegkundigen meer zal groeien indien verpleegkundigen:

a. hoger scoren op diffuse statuskarakteristieken ('senioriteit')

b. hoger scoren op specifieke statuskarakteristieken ('bekwaamheid')

c. zich gebonden achten aan het realiseren van verpleegkundige innovaties

d. zich in de samenwerking meer koöperatief/probleemoplossend opstellen

e. positief beoordeeld worden door andere leden van de organisatie ("algehele evaluatie')

Aan de verpleegkundigen werden vragen gesteld over de onderdelen $a$ tot en met $d$. Vragen over de onderdelen $d$ en $e$ werden voorgelegd aan de verpleegkundige leiding en artsen. Aan de leidinggevenden en de artsen waren vragen gesteld over 'het zich zelfverzekerd opstellen van verpleegkundigen', 'de groepsgerichte houding van verpleegkundigen' en de 'evaluatie van de verpleegkundige". Deze variabelen bleken onderling zo sterk samen te hangen dat deze variabelen werden samengenomen (zie paragraaf 6.1) en benoend als 'algehele evaluatie' (e).

De hypothese verondersteld dat de invloedspositie van verpleegkundigen voorspeld moet kunnen worden door de hiervoor genoemde variabelen ( $a$ tot en met $e$ ). Voor de drie groepen respondenten wordt met behulp van een stapsgewijze lineaire regressie-analyse nagaan, in welke mate dit het geval is. In de analyses zijn de machts- en invloedsvariabelen de afhankelijke variabelen en (een deel van) de variabelen $a$ tot en met $e$ de prediktoren. Eerst zal --per respondentenkategorie-- een regressie-analyse uitgevoerd worden. Daarna wordt gekeken of de signifikante prediktoren de gevonden verschillen in gepercipieerde invloed van de verpleegkundigen uit de experimentele en kontrole konditie kunnen verklaren. Dit gebeurt met behulp van een variantie-analyse met de machts- en invloedsvariabelen als afhankelijke variabele, de konditie als faktor 
en de signifikante prediktoren alis kovariaat. In de derde plaats wordt nagegaan of de regressie-lijnen in beide kondities parallel lopen (zie ook paragraaf 5.4). Daarbij wordt nagegaan of de korrelaties tussen de machts- en invloedsvariabelen en de prediktoren in de twee kondities signifikant van elkaar verschillen. Indien dit het geval blijkt te zijn, wordt tenslotte nagegaan of de gevonden werschillen in waargenomen invloed vam verpleegkundigen uit de twee kondities verklaard kan worden, door deze prediktoren voor de twee kondities afzonderlijk als kovariaat mee te nemen. Dit impliceert dat er een model getoetst wordt waarin verschillende gewichten voor het kovariaat in de twee kondities wordt toegestaan. De hiervoorgenoemde analyses voor de drie groepen respondenten (werpleegkundigen, de verpleegkundige leiding en artsen) worden hierna afzonderlijk beschreven.

De verpleegkaindigen. Nagegaan is hoe de door verpleegkundigen ervaren eigen invloed gerelateerd is aan de wijze waarop verpleegkundigen zich opstellen in overleg met de verpleegkundige leiding en artsen (probleemoplossend/koöperatief, konfronterend/kompetitief), de senioriteit van verpleegkundigen, de mate waarin verpleegkundigen aangeven een aantal specifieke verpleegkundige aktiviteiten te beheersen ('bekwaamleid") en de mate waarin verpleegkundigen zichzelf gebonden voelen aan het succesvol invoeren van verpleegkundige innovaties.

Alvorens deze relaties te onderzoeken, wordt nagegaan of verpleegkundigen uit de twee kondities onderling ten aanzien van de hiervoorgenoemde variabelen verschillen. Het blijkt dat de 'senioriteit' van verpleegkundigen van experimentele eenheden niet verschilt van de 'senioriteit' van verpleegkundigen van kontrole eenheden: $F(1,420)=$ 1.19 , ns. Ze vinden zichzelf niet meer koöperatief ten opzichte van de artsen en de verpleegkundige leiding: $F(1,291)=1.84$, ns en $F(1,289)=2.92$, ns. Ook schatten verpleegkundigen van experimentele eenheden hun eigen bekwaamheid niet hoger in: $F(1,432)=2.36$, ns. Wel blijkt dat verpleegkundigen van experimentele eenheden zich meer gebonden achten aan het realiseren van verpleegkundige innovaties dan verpleegkundigen uit de kontrole konditie: $F(1,299)=4.19, \mathrm{p}<.05$.

De mate waarin verpleegkundigen vïnden dat zij zelf invloed hebben, is gerelateerd $(\mathrm{p}<.001)$ aan de door hen zelf ingeschatte bekwaamheid $(r=.40)$, hun verbondenheid met innovaties in de verpleging $(r=.40)$, de mate waarin verpleegkundigen 'zich kooperatief opstellen in overleg met artsen" $(r=.26)$ en 'zich koöperatief opstellen in het overleg met de verpleegkundige leiding' $(r=.19)$. De overige korrelaties zijn klein $(|\mathrm{r}|<.10)$. Bij een stapsgewijze multiple regressie met als kriterium de 'gepercipieerde eigen invloed' en de overige hiervoorgenoemde variabelen als prediktoren, dragen 'bekwaamheid' en 'gebondenheid' signifikant bij aan het voorspellen van 'invioed' (Tabel 6-9-a). Worden deze twee prediktoren als kovariaat opgenomen in een variantie-analyse, met als afhankelijke variabele 'invloed' en als faktor 'konditie', dan blijkt dat bekwaamheid en gebondenheid sterk samenhangen met de gepercipieerde invloed, maar dat na introduktie van de twee kovariaten het effekt 'konditie' signifikant blijft (vergelijk Tabel 6-9-a, 6-9-b en 6-9-c). 
Tabel 6-9.

a. Stapsgewijze regressie met als afharkelijke variabele "de invloed wan verpleegkundigen ingeschat door verpleegkundigen'

b. Variantie-analyse met als afhankelijke variabele 'inwoed' en as faktor 'konditie' (experimenteel/kontrole)

c. Variantie-analyse met als aftankelijke variabele "invloed", met 'bekwamheid" en "gebondenheid' als kovariatat en "konditie" als faktor

d. Toets voor non-parallellisme na introduktie van de kovariaten en de faktor "konditie" in het modell

\begin{tabular}{|c|c|c|c|c|c|}
\hline a. & prediktoren & $\mathrm{R}$ & $B^{*}$ & $\mathrm{t}$ & $\mathrm{p}<$ \\
\hline stap 1 & bekwaamheid & .40 & .28 & 4.71 & .001 \\
\hline stap 2 & gebondenheid & .47 & .28 & 4.68 & .001 \\
\hline \multicolumn{6}{|l|}{ b. } \\
\hline Bron & & $\mathrm{F}$ & df & $\mathbb{p}<$ & \\
\hline konditie & & 4.70 & 1,290 & .05 & \\
\hline \multicolumn{6}{|l|}{ c. } \\
\hline Bron & & Fo & $\mathrm{df}$ & $\mathrm{p}<$ & \\
\hline kowariatem & & 43.23 & 2,288 & .001 & \\
\hline konditie & & 4.50 & 1,288 & .05 & \\
\hline \multicolumn{6}{|l|}{ d. } \\
\hline \multicolumn{2}{|l|}{ Bron } & $\mathrm{F}$ & df & $\mathrm{p}<$ & \\
\hline \multicolumn{2}{|c|}{ kovariaten $\mathrm{x}$ konditie } & 1.40 & 2,286 & ns & \\
\hline
\end{tabular}

* B-gewichten na twee stappen.

De regressie-lijnen in de twee kondities lopen parallel (Tabel 6-9-d).

Vastgesteld kan worden dat 'bekwaamheid" en "gebondenheid', in beide kondities samenhangen met de door verpleegkundigen ervaren invloed. Het verschil in de door de verpleegkundigen waargenomen eigen invloed, kan niet door deze twee prediktoren worden verklaard. De twee prediktoren 'de door verpleegkundigen gehanteerde koöperatieve beïnvloedingsstrategieën ten opzichte van artsen' en 'het gebruik van koöperatieve strategieën ten opzichte van de verpleegkundige leiding' korreleren weliswaar signifikant met 'de invloed van een verpleegkundige', maar deze samenhang kan verklaard worden door de specifieke statuskarakteristiek 'bekwaamheid' en door 'gebondenheid'. Het gebruik van konfronterende beïnwloedingsstrategieën en 'senioriteit', hangen niet samen met de invloed die een verpleegkundige ervaart. Konfronterende beïnvloedingsstrategieën worden overigens over de gehele linie weinig tot zeer weinig gebruikt (gemiddelde 1.52) in vergelijking met koöperatieve/probleemoplossende strategieền (gemiddelde 3.08 , bij een range van $\mathbb{1}$ tot 5 ).

De verpleegkundige leiding. De verpleegkundige leiding heeft de door hem/haar waargenomen invloed van afzonderlijke verpleegkundigen aangegeven, het funktioneren van afzonderlijke verpleegkundigen geëvalueerd en de door afzonderlijke verpleegkundigen gehanteerde beïnvloedingsstrategieën beoordeeld.

De door de leiding gepercipieerde invloed wan de verpleegkundige hangt met name 
samen met de algehele evaluatie van de verpleegkundige door de leiding en het gebruik van probleemoplossende strategieền door de verpleegkundige (respektievelijk $\mathrm{r}=.54$ en $\mathrm{r}=.30$, beide $\mathrm{p}<.001$ ). Alleen de eerste van deze twee prediktoren wordt in een stapsgewijze regressie (kriterium: $\mathrm{p}<.05$ ) opgenomen. Aangezien de verpleegkundige leiding van experimentele en kontrole eenheden onderling niet verschillen in de door hen ingeschatte invloed van individuele verpleegkundigen $(\mathrm{F}[1,503]=2.04$, ns), is het niet zinvol om na te gaan of de 'algehele evaluatie' een verschil in waargenomen invloed tussen de kondities zou kunnen verklaren.

De artsen. De artsen werd na de eerste meetperiode niet meer gevraagd de individuele verpleegkundigen te beoordelen. Daarom is nagegaan in welke mate de evaluatie door artsen van een verpleegkundig team en de door artsen gepercipieerde beïnvloedingsstrategieën van een verpleegkundig team gerelateerd is aan de waargenomen invloed van verpleegkundigen (dat wil zeggen: de invloed op de zorg, de invloed op de algemene gang van zaken op de verpleegeenheid, het zelfstandig kunnen beslissen in de zorg, of er met verpleegkundigen overlegd moet worden alvorens artsen zelf beslissingen kunnen nemen en de mate waarin artsen zich in hun funktioneren afhankelijk voelen van verpleegkundigen). De samenhang tussen deze invloedsvariabelen enerzijds en de evaluatie door artsen en de door verpleegkundigen gebruikte beënwloedingsstrategieën anderzijds is zwak. De twee prediktoren ('het gebruik van koöperatieve strategieën' en 'algehele evaluatie') korreleren alleen signifikant met één van de vijf kriterium variabelen, namelijk met de invloed die verpleegkundigen volgens artsen hebben op specifieke zorgaspekten (respektievelijk $\mathrm{r}=.29, \mathrm{p}<.05$ en $\mathrm{r}=.27$, $p<.05$ ). In een stapsgewijze regressie (kriterium: $p<.05$ ) met als afhankelijke variabele 'de door de artsen walargenomen invloed van verpleegkundigen op de zorg', wordt alleen de 'algehele evaluatie' in de vergelijking opgenomen $(t=2.02, \mathrm{df}=44, \mathrm{p}<.05)$. Uit een secundaire analyse blijkt dat artsen van experimentele eenheden de verpleegkundigen meer negatief beoordelen dan artsen van kontrole eenheden (Tabel 6-10-a). De door artsen gepercipieerde invloed van verpleegkundigen bleek samen te hangen met deze 'algehele evaluatie'. In een variantie-analyse met de 'algehele evaluatie' als afhankelijke variabele en 'invloed' als kovariaat, blijkt dat 'invloed' de verschillen in evaluatie door artsen wan verpleegkundigen in de twee kondities niet kan verklaren (Tabel 6-10-b). De regressie-lijnen lopen in beide kondities parallel (Tabel 6-10-c). De andere vier 'invloedsvariabelen' bleken niet samen te hangen met de variabele 'algehele evaluatie'. Wanneer echter onderscheid gemaakt wordt tussen de experimentele en kontrole konditie, dan blijkt dat de korrelatie tussen de algehele evaluatie door artsen en de mate waarin artsen aangeven dat zij moeten overleggen met verpleegkundigen wel signifikant is binnen de afzonderlijke kondities: respektievelijk $r=-.57, n=14, p<.05$ en $r=.44, n=31, p<.01$. Dit betekent dat artsen op experimentele eenheden vinden dat naarmate er meer overlegd moet worden met verpleegkundigen de verpleegkundigen minder positief worden beoordeeld, terwijl op kontrole eenheden verpleegkundigen beter worden beoordeeld naarmate er meer wordt overlegd met verpleegkundigen. In een variantie-analyse met de 'algehele evaluatie' als afhankelijke variabele, 'overleg' als kovariaat en de konditie als faktor, blijkt het kovariaat niet signifikant. De regressielijnen lopen echter in de beide kondities niet parallel (Tabel 6-10-d). 
Tabel 6-10.

a. Variantie-analyse met als afharkelijke variabele aigehele exaluatie door artsen' en 'konditie" als faktor (experimenteel/kontrole)

b. Variantie-analyse met 'algehele evaluatie' als afhankelijke variabele, "imvloed" als kovariaat en 'konditie" als faktor

c. Toets voor non-parallellisme na introduktie van het kovariaat en de faktor in de analyse

d. Variantie-analyse met als afhankelijke variabele "algehele evaluatie', als kovariaat 'overleg", als faktor "konditie" en de interaktieterm 'kovariaat $x$ konditie' (toets woor non-parallellisme)

e. Variantie-analyse met als afhankelijke variabele "algehele evaluatie" en als kovariaat, binnen de twee kondities afzonderlijk, 'overleg'

\begin{tabular}{|c|c|c|c|}
\hline$\overline{\text { Bron }}$ & $F$ & df & $\bar{p}<$ \\
\hline \multicolumn{4}{|l|}{ a. } \\
\hline konditie & 8.89 & 1,43 & .01 \\
\hline \multicolumn{4}{|l|}{ b. } \\
\hline invloed & 6.56 & 1.42 & .05 \\
\hline konditie & 12.44 & 1,42 & .01 \\
\hline \multicolumn{4}{|l|}{ c. } \\
\hline invloed $x$ konditie & 290 & 1,41 & nss \\
\hline \multicolumn{4}{|l|}{ d. } \\
\hline overleg & .20 & 1,41 & ns \\
\hline konditie & 10.64 & 1,41 & .01 \\
\hline overleg $\mathrm{x}$ konditie & 9.17 & 1,41 & .01 \\
\hline \multicolumn{4}{|l|}{ e. } \\
\hline 'overleg' binnen 'konditie' & 9.94 & 2,41 & .001 \\
\hline konditie & .13 & 1,41 & ns \\
\hline
\end{tabular}

Wanneer in de twee kondities afzonderlijk een regressie-analyse wordt uitgevoerd met als kovariaat 'overleg', dan blijkt het kovariaat wel signifikant. Bovendien bijjkt het effekt 'konditie' geheel verdwenen (Tabel 6-10-e). Het blijkt verder dat artsen van experimentele eenheden zeggen meer overleg te moeten voeren met verpleegkundigen dan artsen van kontrole eenheden: $F(1,43)=4.95, p<.05$. Hoewel het hier gaat om korrelationele relaties, lijkt de volgende redenering het meest plausibel. Met verpleegkundigen van experimentele eenheden moeten artsen meer overleg plegen dan met verpleegkundigen van kontrole eenheden. Artsen vinden dat op experimentele eenheden te veel met individuele verpleegkundigen moet worden overlegd hetgeen kan verklaren waarom verpleegkundigen op de experimentele eenheden minder positief door artsen worden geëvalueerd dan op kontrole eenheden.

Samengevat. Vastgesteld kan worden dat hypothese 3 in zekere mate door het werzamelde materiaal wordt ondersteund. Van de vijf prediktoren, vertoont er eén ('senioriteit') geheel geen samenhang met de machts- en invioedsvariabelen. 
'Bekwatamheid' en "gebondenheid", beoordeeld door de verpleegkundige, hangen positief samen met de door hen waargenomen invloed. Ten aanzien wan het materiaal verzameld bij de verpleegkundige leiding en artsen, blijkt dat naar hun oordeel de 'algehele evaluatie' en de mate waarin verpleegkundigen zich koöperatief opstellen in de samerwwerking, positief samenhangen met de door hen waargenomen invloed van verpleegkundigen. Het is met name de 'algehele evaluatie' die samenhangt met de waargenomen invloed. Gekonkludeerd kan worden dat de invloed van verpleegkundigen voorspeld kan worden door de algehele evaluatie van de verpleegkundigen door artsen en de leiding, de door verpleegkundigen ingeschatte eigen bekwaamheid en de mate waarin verpleegkundigen zich gebonden voelen aan het realiseren van verpleegkundige vernieuwingen. Uit een secundaire analyse is gebleken dat artsen verpleegkundigen van experimentele eenheden minder positief beoordelen, maar dat dit verklaard kan worden door de bevinding dat zij met hen meer overleg moeten voeren alvorens zij besiissingen in de verzorging en behandeling van patiënten kunnen nemen. Op dit laatste wordt in het volgende hoofdstuk, wanneer de gevolgen van Integrerende Verpleegkunde voor de arts besproken worden, nader ingegaan.

\section{Gevolgen van taakverruiming.}

Verwacht wordt dat door de taakverruiming als gevolg van de introduktie van Integrerende Verpleegkunde, de positie van verpleegkundigen zal worden versterkt, maar dat naarmate verpleegkundigen een lagere senioriteit hebben (minder ervaring hebben, minder lang op een eenheid werkzaam zijn enz.) en minder opleiding hebben genoten, zij meer onzekerheid zullen gaan ervaren (hypothese 4, paragraaf 3.3). Verpleegkundigen werd gevraagd naar de door hen ervaren onzekerheid ('niet weten hoe de aktiviteit uit te voeren') ten aanzien van $a$. de samenwerking met kollega's en andere disciplines, $b$. de begeleiding van de patiënt en $c$. de koördinatie van de zorg. Omdat deze drie variabelen onderling sterk samenhangen (Cronbach's alpha $=.81$ ), zijn de variabelen gesommeerd ('onzekerheid').

De mate waarin verpleegkundigen van experimentele eenheden onzekerheid ervaren verschilt niet van de mate waarin verpleegkundigen van kontrole eenheden onzekerheid ervaren: $F(1,408)=3.09$, ns. Het blijkt dat verpleegkundigen met een inservice, MBO of $\mathrm{HBO}$ opleiding in de verpleging, niet in verschillende mate onzekerheid ervaren: $F(2,408)=1.46$, ns. Ook het interaktie-effekt 'konditie $x$ opleiding' is niet signifikant $: F(2,408)=1.98$, ns. Voor de senioriteit van verpleegkundigen geldt, dat deze enigszins negatief samenhangt met de ervaren onzekerheid: $\mathrm{r}=-.12, \mathrm{p}<.05$. De samenhang verschilt niet voor de twee kondities: toets voor non-parallellisme: $F(1,400)=.07$, ns. Gekonkludeerd kan worden dat verpleegkundigen uit de twee kondities in gelijke mate onzekerheid ervaren. De taakverruiming als gevolg van Integrerende Verpleegkunde lijkt dus geen onzekerheid te hebben veroorzaakt. De genoten opleiding is niet gerelateerd aan het ervaren van onzekerheid, terwijl de senioriteit van verpleegkundigen een zwakke negatieve samenhang vertoont met de ervaren onzekerheid. Hypothese 4 ondervindt enige ondersteuning.

Overleg en behoefte aan overleg. Verwacht wordt (hypothese 5, paragraaf 3.3) dat door onzekerheid de behoefte aan overleg groter wordt en dat de relatie tussen onzekerheid en deze behoefte sterker is naarmate de 'gepercipieerde gelijkheid' groter 
is, verpleegkundigen de voorkeur geven aan probleemoplossende strategieên en verpleegkundigen veronderstellen dat anderen op de verpleegeenheid overleg als instrumenteel zien (sociale norm). Dit betekent dat verwacht wordt dat de behoefte aan overleg bepaald wordt door een kombinatie van de variabele 'onzekerheid' en de drie hiervoorgenoemde konditionele variabelen. Deze interakties kunnen getoetst worden door middel van een multiple regressie (zie Finney, Mitchell, Cronkite \& Moos, 1984; Wheaton, 1985). De multiplikatieve termen van de ervaren onzekerheid (range 0 tot 4) en elk van de drie konditionele variabelen (waargenomen gelijkheid, sociale norm, probleemoplossende strategieën: allen met een range van 0 tot 3) kunnen beschouwd worden als de interaktie-termen. De signifikantie van deze interaktie-termen kan getoetst worden door in een multiple regressie met als aflankelijke variabele 'de behoefte aan overleg', een interaktie-term in het model te introduceren, nadat de variabelen aan de hand waarvan de interaktie-term is berekend, in de vergelijking zijn opgenomen. Dit betekent dat wordt nagegaan of de korrelaties tussen de drie interaktie-termen en de behoefte aan overleg afwijken van nul, nadat deze korrelatie is gekorrigeerd voor 'onzekerheid' en de betreffende konditionele variabele. Deze partiële korrelaties tussen de behoefte aan overleg en de multiplikatieve termen 'onzekerheid $\mathrm{x}$ waargenomen gelijkheid', 'onzekerheid $\mathrm{x}$ sociale norm' en 'onzekerheid $\mathrm{x}$ probleemoplossende strategieën', bedragen respektievelijk $-.09,-.07$ en -.02 . Deze korrelaties zijn geen van allen signifikant. Het blijkt overigens dat geen van de variabelen 'onzekerheid', 'waargenomen gelijkheid' en 'sociale norm' samenhangt met de behoefte aan overleg. Alleen de mate waarin verpleegkundigen 'probleemoplossend' op onzekerheid zeggen te reageren, hangt zwak positief samen met de behoefte aan overleg $(r=.17, \mathrm{p}<.001)$. Hypothese 5 wordt niet ondersteund.

De werpleegkundigen werd ook gevraagd aan te geven in welke mate recentelijk (de laatste weken) met kollega's overleg heeft plaatsgevonden over problemen rond de begeleiding van patiënten, de samenwerking en de koördinatie van de zorg. Verpleegkundigen van experimentele en kontrole eenheden hebben in de voorgaande periode niet in verschillende mate over deze onderwerpen gesproken: $F(1,415)=.61$, ns. Wel bestaat $\mathrm{er}$ in beide kondities een negatieve samenhang tussen de mate waarin men onzekerheid ervaart en de mate warin men recentelijk met kollega's overleg heeft gevoerd: $\mathrm{r}=-.33, \mathrm{n}=415, \mathrm{p}<.001$. Ook bestaan er signifikante korrelaties $(\mathrm{p}<.001)$ tussen de mate waarin men onzekerheid ervaart en de waargenomen gelijkheid $(-.34)$, de sociale norm $(-.32)$ en het gebruik van probleemoplossende strategieën $(r=-.19)$. Aan de hand van een secundaire analyse is nagegaan of de negatieve korrelatie tussen 'het recentelijk hebben overlegd' en de 'ervaren onzekerheid', verklaard kan worden door de drie genoemde konditionele variabelen. Het is bijvoorbeeld mogelijk dat door overleg men meer gelijkheid gaat waarnemen, waardoor de onzekerheid wordt verminderd.

De partiële korrelatie tussen 'het recentelijk hebben overlegd' en 'de ervaren onzekerheid', gekorrigeerd voor 'de waargenomen gelijkheid', 'de sociale norm' en het gebruik van probleemoplossende strategieën, bedraagt -.28 ( $\mathrm{p}<.001)$. De korrelatie kan met andere woorden niet door de drie konditionele variabelen worden verklaard.

Samengevat kan vastgesteld worden dat de verpleegkundigen uit de twee kondities onderling niet verschillen in de mate waarin zij onzekerheid ervaren, behoefte hebben aan overleg met kollega's en recentelijk met hen hebben overlegd. Het blijkt verder dat 
de mate waarin men onzekerheid ervaart niet samenhangt met de behoefte aan overleg. Ook niet indien de omstandigheden hiervoor gunstig lijken (bijvoorbeeld wanneer de verpleegkundige verwacht dat kollega's vergelijkbare onzekerheden ervaren). Hypothese 5 wordt daarmee niet ondersteund. Wel blijkt dat naarmate men recentelijk meer heeft overlegd, men minder onzekerheid ervaart.

\subsection{Samenvatting en diskussie.}

In de vorige paragraaf zijn de gevolgen van de introduktie van Integrerende Verpleegkunde voor de verpleegkundigen besproken. In deze paragraaf worden deze resultaten kort samengevat en worden enkele diskussiepunten besproken.

\section{Samenvatting.}

Verwacht werd dat verpleegkundigen door de toestemming met Integrerende Verpleegkunde te mogen experimenteren en door patiënttoewijzing meer handelingsruimte zouden gaan ervaren (hypothese 1). Het blijkt dat verpleegkundigen meer handelingsruimte ervaren ten aanzien van het uitvoeren van verpleegtechnische verrichtingen en de lichamelijke verzorging van patiënten en ten aanzien van het beleid wan de eenheid. Ook ervaren ze meer mogelijkheden om zelfstandig te werken.

Verwacht werd dat door de introduktie van patiênttoewijzing en het gebruik van de methode van systematisch verpleegkundig handelen de verpleegkundigen een ruimere taak op zich zouden nemen en daarmee van de verkregen handelingsruimte gebruik zouden maken (onderdeel wan hypothese 2). Het blijkt dat, overeenkomstig de verwachting, er inderdaad sprake is van taakverruiming wat de bijdrage aan het beleid en de bijdrage aan het uitvoeren van verpleegtechnische verrichtingen betreft. De grotere bijdrage aan beleid kan gezien worden als een verticale taakverruiming en de grotere bijdrage aan de verpleegtechnische verrichtingen meer als een horizontale taakverruiming.

Verwacht werd dat verpleegkundigen op experimentele eenheden hun machtspositie zouden versterken (hypothese 2). De machtspositie werd daarbij geoperationaliseerd in termen wan de invloed op de gang van zaken op de eenheid, de invloed op specifieke aspekten van de zorg, de mate waarin verpleegkundigen zelfstandig kunnen beslissen en de mate waarïn anderen met verpleegkundigen overleg moeten plegen voordat zij beslissingen kunnen nemen (vergelijk Veen, 1982). Het blijkt dat de gegevens verzameld bij cle verpleegkundigen, de verpleegkundige leiding, de artsen en de patiënten deze hypothese ondersteunen en dat er redelijke veel konsensus bestaat tussen de verschillende respondentengroepen over de sterkere machtspositie van verpleegkundigen op experimentele eenheden ten opzichte van verpleegkundigen op kontrole eenheden. De grootste verschillen bestaan ten aamzien van:

a. de mate waarin met verpleegkundigen overleg gepleegd moet worden alvorens beslissingen in de zorg genomen kunnen worden. Voor de verpleegkundige leiding zijn de verschillen tussen experimentele en kontrole eenheden het grootst,

b. de mate waarin verpleegkundigen zelfstandig beslissingen kunnen nemen en

c. de mate waarin verpleegkundigen van experimentele eenheden in vergelijking 
tot verpleegkundigen van kontrole eenheden afhankelijk zijn wan kollega"s.

Deze resultaten sluiten aan bij de bedoelingen van Integrerende Verpleegkunde. Dit model beoogt immers dat met name rondom de directe patiëntenzorg de verpleegkundige een zelfstandige en koördinerende rol krijgt. Dit blijkt het geval te zijn. Tevens is gebleken dat alle groepen respondenten --ongeacht hoe ze dit waarderen-w vinden dat de verpleegkundige meer invloed heeft gekregen op de verzorging van individuele patiënten.

Verwacht werd (hypothese 3) dat verpleegkundigen in sterkere mate hun machtspositie zouden versterken indien zij hoger scoren op diffuse (a) en specifieke statuskarakteristieken (b), zich gebonden achten aan de innovatie (c), zich in de samenwerking koöperatief opstellen (d) en hun taakbijdrage positief wordt geëvalueerd (e). Het blijkt dat de door verpleegkundigen ervaren invloed samenhangt met de mate waarin zij gemotiveerd zijn de innovatie te realiseren (c) en zichzelf bekwaam achten (specifieke statuskarakteristiek [b]). In de beleving van de verpleegkundige leiding en de artsen bestaat er enige samenhang tussen de door hen waargenomen invloed van verpleegkundigen en de mate waarin de werkzaamheden door hen positief worden geëvalueerd (e) en de mate waarin verpleegkundigen zich koöperatief opstellen (d). Verpleegkundigen van experimentele eenheden achten zichzelf meer gebonden aan de innovatie dan verpleegkundigen van kontrole eenheden (c), maar zij worden door artsen meer negatief beoordeeld (e). De variabelen (a tot en met e) kunnen de verschillen in waargenomen invloed tussen de twee kondities niet volledig verklaren. Hypothese 3 wordt deels bevestigd.

Verwacht werd dat taakverruiming onzekerheid bij verpleegkundigen zou veroorzaken, indien verpleegkundigen weinig ervaring hebben (lage senioriteit) of wanneer zij weinig opleiding hebben genoten (hypothese 4). Deze hypothese wordt niet bevestigd. Verpleegkundigen uit de twee kondities ervaren in gelijke mate onzekerheid. Wel blijkt dat verpleegkundigen wat minder onzekerheid ervaren naarmate zij meer ervaring hebben.

Wat de verwachtingen betreft omtrent de relatie tussen het voeren van overleg, het ervaren van onzekerheid, de behoefte aan overleg en enkele konditionele faktoren (hypothese 5), kan vastgesteld worden dat er geen verschillen gevonden zijn tussen experimentele en kontrole eenheden. De ervaren onzekerheid blijkt niet gerelateerd aan de behoefte aan overleg, ook niet onder bepaalde kondities. Wel blijkt de mate waarin overleg heeft plaatsgevonden negatief samen te hangen met de ervaren onzekerheid. De onderzochte kondities (gepercipieerde gelijkheid, sociale normen op de eenheid en de ervaren instrumentaliteit van overleg) blijken ook negatief samen te hangen met het ervaren van onzekerheid. Hoewel het hier korrelationele relaties betreft, is er meer ondersteuning voor de gedachte dat overleg onzekerheid reduceert dan dat onzekerheid de behoefte aan overleg doet toenemen.

\section{Diskcussie.}

Naar aanleiding van hypothese 1 is gebleken dat de terreinen waarop de handelingsruimte en de taakbijdrage is toegenomen, niet geheel overeenkomen met de verwachtingen. Vanwege de koördinerende rol van de verpleegkundigen werd verwacht dat zij meer zouden moeten samenwerken en overleggen met bijwoorbeeld artsen. Tevens werd verwacht dat er door intensiever kontakt met individuele patiënten, meer 
njet-somatische problemen door patiënten naar voren zouden worden gebracht. Verpleegkundigen zouden daardoor meer tjjd gaan besteden aan de begeleiding van patiënten. Op deze terreinen blijken verpleegkundigen van experimentele eenheden, naar hun eigen oordeel, geen grotere taakbijdrage te leveren dan verpleegkundigen van kontrole eenheden. Dat verpleegkundigen geen grotere taakbijdrage leveren aan de samenwerking, kan met behulp van enkele andere resultaten mogelijk worden verklaard. Verpleegkundigen hebben aangegeven dat zij minder afhankelijk zijn van kollega's. Doordlat verpleegkundigen patiënten toegewezen krijgen in plaats van taken, zall het minder vaak nodig zijn om met kollega's over individuele patiënten te overleggen om de verschillende taken die rondom een patiënt moeten worden uitgevoerd op elkaar af te stemmen. Verder blijkt dat men vindt dat met artsen meer wordt overlegd (zie 7.2). Het is zo aannemelijk dat verpleegkundigen over het geheel genomen geen grotere bijdrage leveren aan de samenwerking, maar dat er wel verschuivingen zijn opgetreden in de personen waarmee wordt overlegd.

In het vorige hoofdstuk is gebleken dat patiënten op experimentele eenheden door minder verschillende verpleegkundigen worden verzorgd. Patiënten bleken echter maar in beperkte mate expliciet door de verpleegkundigen bij het plannen en uitvoeren van de zorg te worden betrokken. Juist tijdens interakties over het doel, de planning en de evaluatie van de zorg zullen patiënten sneller hun niet-somatische problemen, die om (extra) begeleiding vragen, naar voren brengen. Dit kan verklaren waarom verpleegkundigen van experimentele verpleegeenheden in vergelijking met verpleegkundigen uit de kontrole konditie aangeven niet meer aandacht te besteden aan de begeleiding van patiënten. 


\section{HOOFDSTUK 7 \\ GEVOLGEN VAN INTEGRERENDE VERPLEEGKUNDE VOOR ANDERE GROEPERINGEN}

\subsection{Inleiding}

In hoofdstuk 3 werd ingegaan op de gevolgen van de machtstoename van een groep personen in een organisatie (of van personen in een groep) voor andere leden in die organisatie. Uit de beschreven literatuur bleek, dat de invloedsverandering van de cén niet ten koste hoeft te gaan van de invloedspositie van een ander. Er zijn aanwijzingen dat koöperatie en participatie de invloedspositie van een ieder kunnen versterken. We noemden dit de 'groeiende koek hypothese'. Nagegaan wordt hoe volgens de verschillende groepen respondenten het met de invloedspositie van diverse andere kategorieën personen is gesteld. Over de positie van andere groepen werden vragen gesteld aan verpleegkundigen, aan de verpleegkundige leiding, aan de artsen en aan de patiënten. Hoewel de inhoud van de vragen al werd besproken in de hoofdstukken 5 en 6, worden de vragen hier nogmaals kort samengevat. Vragen werden gestelld over:

a. de invloed van de verpleegkundige leiding, de zaalarts, de specialist, de koördinerend hoofdverpleegkundige, de hoogleraar en de medische registratie-assistent op de 'algehele gang van zaken op de verpleegeenheid'. Dit werd beoordeeld door de verpleegkundigen, de leidinggevenden en de artsen.

b. de invloed van de verpleegkundige leiding, de zaalarts, de specialist en de patiënt op specifieke zorgaspekten (zie Bijlage V) volgens de verpleegkundige leiding, verpleegkundigen en artsen. De patiënten hebben aangegeven hoeveel invloed zij zelf, de verpleegkundigen en de artsen hebben op specifieke zorgaspekten (zie Bijlage I).

c. de mate waarin men rekening moet houden met diverse kategorieën personen (zie a) volgens de verpleegkundigen, de leiding en artsen (algemene afhankelijkheid).

d. de mate waarin de verpleegkundige leiding, de zaalarts, de specialist en de patiënt zelfstandig beslissingen kunnen nemen ten aanzien van specifieke zorgaspekten (zie Bijlage IV).

e. de mate waarin de verpleegkundige leiding, de zaalarts, de specialist en de patiënt bij overleg over specifieke onderdelen van de zorg worden betrokken volgens de verpleegkundige leiding, de verpleegkundigen en de artsen (zie Bijlage IV).

Deze onderdelen komen overeen met de onderwerpen waarover vragen werden gesteld aan de verpleegkundigen. Ten aanzien van de verpleegkundigen werd ook nog gevraagd naar de invloed van individuele verpleegkundigen. Er zijn een aantal analyses uitgevoerd over de afzonderlijke onderdelen ( $a$ tot en met $e$ ). Eerst worden deze (multivariate) analyses in het kort besproken. Daarna worden de invloedsposities van de afzonderlijke groeperingen binnen de organisatie aan de hand van de univariate analyses behandeld. In de analyses worden twee faktoren onderscheiden, namelijk een 
faktor 'konditie" (exp/kontr) en een faktor 'respondentengroep' (verpleegkundigen, verpleegkundige leiding, artsen, patiënten).

\subsection{Resultaten}

\section{Overzicht van de analyses.}

Ten aanzien van de invloed op de algemene gang van zaken op de verpleegeenheid (onderdeel a) wordt een multivariaat hoofdeffekt 'konditie' en een multivariaat hoofdeffekt 'respondentengroep' gevonden (Tabel 7-1). Het eerste hoofdeffekt geeft aan dat over de invloed van diverse groepen personen op de algemene gang van zaken op experimentele en kontrole verpleegeenheden verschillend wordt gedacht. Het tweede hoofdeffekt geeft aan dat in beide kondities de drie groepen respondenten (verpleegkundigen, verpleegkundige leiding en artsen) verschillend denken over de invloed van diverse groepen personen op de algemene gang van zaken op de verpleegeenheid.

Tabel 7-1. De invloed wan de koördinerend hoofdverpleegkundige (CHV), de werpleegkundige leiding (vkleid), de zaalarts (za), de medisch specialist (spec), de hoogleraar (hglr) en de medische registratte-assistent (regas) op de algemene gang van zaken op de verpleegeenheid. Als faktoren zijn in het ontwerp opgenomen de konditie (exp/kontr) en de groep respondenten (resp): verpleegkundigen (vk), de verpleegkundige leiding (vkleid) en de artsen (arts).

\begin{tabular}{|c|c|c|c|c|c|c|c|c|c|}
\hline \multirow[t]{2}{*}{ Bron } & \multirow[b]{2}{*}{$F$} & \multicolumn{2}{|l|}{ Multivariaat } & \multicolumn{2}{|c|}{ Univariaat } & \multirow[b]{2}{*}{$\mathrm{p}<$} & \multicolumn{3}{|c|}{ Gemiddelden } \\
\hline & & $d f$ & $p<$ & variabele & $\mathrm{F}^{*}$ & & & xp & Kontr \\
\hline \multicolumn{10}{|c|}{$\overline{\operatorname{Exp} / \text { Kontr }}$} \\
\hline & 4.58 & 6,542 & .001 & $\mathrm{CHV}$ & 3.96 & .05 & & 83 & 2.62 \\
\hline & & & & vkleid & .91 & ns & & & \\
\hline & & & & za! & 2.83 & ns & & & \\
\hline & & & & spec & 2.51 & ns & & & \\
\hline & & & & hglr & .04 & ns & & & \\
\hline & & & & regas & 13.06 & .001 & & 55 & 2.24 \\
\hline & & & & & & & wk & vkleid & arts \\
\hline \multirow[t]{6}{*}{$\operatorname{Resp}$} & 6.59 & 12,1084 & .001 & $\mathrm{CHV}$ & 12.30 & .001 & 2.81 & 1.93 & 271 \\
\hline & & & & vkleid & 1.67 & ns & & & \\
\hline & & & & za & 6.33 & .01 & 2.93 & 2.54 & 3.22 \\
\hline & & & & spec & 2.92 & ns & & & \\
\hline & & & & hglit & 3.04 & .05 & 2.35 & 1.91 & 2.29 \\
\hline & & & & regas & 13.91 & .001 & 2.31 & 2.11 & 2.91 \\
\hline
\end{tabular}

Exp/Kontr x Resp

$99 \quad 12,1084 \quad$ ns

* wrijheidsgraden bij univariate toetsen 'konditie': $\mathrm{df}=1,547$

wrijheidsgraden bijj univariate toetsen 'respondent': $\mathrm{df}=2,547$

Ten aanzien van de invloed van diverse groepen personen op specifieke zorg aspekten (onderdeel $b$ ) worden eveneens twee multivariate hoofdeffekten gevonden (Tabel 7-2). Op experimentele en kontrole verpleegeenheden wordt de invloed van 
diverse groeperingen verschillend beoordeeld. Ook hier blijkt dat in beide kondities de drie groepen respondenten verschillend oordelen over de invloed van diverse kategorieën personen op specifieke onderdelen van de zorg.

Tabel 7-2. De invloed van de verpleegkundige leiding (vkleid), do zaalarts (za), de medisch specialist (spec) en de patient (pat) op een aantal specifieke onderdelen van de verzorging Als faktoren zijn in het ontwerp opgenomen de konditie (exp/kontr) en de groep respondenten (resp): verpleegkundigen (vk), de verpleegkundige leïling (vkleid) en de artsen (arts).

\begin{tabular}{|c|c|c|c|c|c|c|c|c|c|}
\hline \multirow[t]{2}{*}{$\overline{\text { Bron }}$} & \multicolumn{3}{|c|}{ Multivariaat } & \multicolumn{3}{|c|}{ Univariaat: } & \multicolumn{3}{|c|}{ Gemiddelden } \\
\hline & $\mathrm{F}$ & df & $p<$ & variabele & $\mathbb{F}^{*}$ & $p<$ & & $x p$ & Kontr \\
\hline \multicolumn{10}{|c|}{ Exp/Kontr } \\
\hline & 9.19 & 4,503 & .001 & vkleid & 28.76 & .001 & & 62 & 2.97 \\
\hline & & & & $\mathbf{z a}$ & .64 & ns & & & \\
\hline & & & & spec & .67 & ns & & & \\
\hline & & & & pat & 3.66 & ns & & & \\
\hline & & & & & & & $\mathrm{vk}$ & vikleic & arts \\
\hline \multirow[t]{4}{*}{ Resp } & 10.98 & 8,1006 & .001 & vkleid & 14.08 & .001 & 2.75 & 3,3 & 2.86 \\
\hline & & & & $\mathrm{za}$ & 3.17 & .05 & 4.15 & 4.1 & 3.98 \\
\hline & & & & spec & 2.98 & $\mathrm{~ns}$ & & & \\
\hline & & & & pat & 25.28 & .001 & 2.18 & 2.7 & 2.75 \\
\hline
\end{tabular}

Exp/Kontr x Resp

$1.47 \quad 8,1006 \quad$ ns

* Vrijheidsgraden bij uniwariate toetsen 'konditie': $d f=1,506$

Vrijheidsgraden bij uniwariate toetsen 'respondent': $\mathrm{df}=2,506$

Wat de mate waarin men zich in het eigen funktioneren afhankelijk voelt wan diverse andere kategorieën personen betreft (onderdeel $c$ ), kan geen multivariate toets uitgevoerd worden. Dit omdat niet aan alle respondenten elke vraag is voorgelegd. De verpleegkundige leiding werd bijvoorbeeld niet gevraagd aan te geven hoe afhankelijk zij van de verpleegkundige leiding is bij het uitvoeren van werkzaamheden. De vraag in welke mate men afhankelijk is van zichzelf lijkt gegeven het onderwerp van onderzoek niet zinvol. De univariate toetsen worden besproken bij de behandeling van de machtspositie van de verschillende groepen personen.

In Tabel 7-3 wordt een overzicht gegeven van de analyse betreffende de mate waarin diverse groeperingen zelfstandig beslissingen kunnen nemen over specifieke onderdelen in de verzorging. Vastgesteld kan worden dat de mate waarin verschillende kategorieën personen zelfstandig beslissingen kunnen nemen op experimentele eenheden afwijkt van de mate waarin dit op kontrole eenheden mogelijk is. De respondenten denken hier gezien het multivariate interaktie-effekt echter verschillend over.

Bij het laatste onderdeel, 'de mate waarin verschillende groepen bij overleg over specifieke zorgaspekten worden betrokken', is er een signifikant multivariaat hoofdeffekt 'konditie' en een signifikant multivariaat hoofdeffekt 'respondentengroep'(Tabel 7 - 
4). De mate waarin diverse groeperingen bij overleg worden betrokken verschilt voor de experimentele en kontrolle konditie. Daarnaast blijkt dat de drie groepen respondenten in beide kondities verschillend denken over de mate waarin groeperingen bij overleg worden betrokken.

Tabel 7-3. De mate waarin de verpleegkundige leiding (vkleid), de zaalarts (za), de medisch specialist (spec) en de patient (pat) zelfstandig beslissingen kunnen nemen over een aantal specifieke onderdelen van de verzorging. Als faktoren zijin in het ontwerp opgenomen de konditie (exp/kontr) en de groep respondenten (resp): verpleegkundigen (vkk), de verpleegkundige leiding (vkleid) en de artsen (arts).

\begin{tabular}{|c|c|c|c|c|c|c|c|c|c|}
\hline \multirow[t]{2}{*}{ Bron } & \multirow[b]{2}{*}{$\mathrm{F}$} & \multicolumn{2}{|c|}{ Multivariaat } & \multicolumn{2}{|c|}{ Univariaat } & \multirow[b]{2}{*}{$\mathrm{p}<$} & \multicolumn{3}{|c|}{ Gemiddelden } \\
\hline & & $d f$ & $\mathrm{p}<$ & variabele & $F^{*}$ & & & & Kontr \\
\hline \multicolumn{10}{|c|}{ Exp/Kontr } \\
\hline & 10.04 & 4,539 & .001 & vkleid & 36.17 & .001 & \multirow{5}{*}{\multicolumn{2}{|c|}{ wk vkleid }} & .41 \\
\hline & & & & za & .44 & ns & & & \\
\hline & & & & spec & .16 & ns & & & \\
\hline & & & & pat & .90 & ns & & & \\
\hline & & & & & & & & & arts \\
\hline \multirow[t]{4}{*}{ Resp } & 4.83 & 8,1078 & .001 & wkleild & 2.26 & $\mathrm{mS}$ & & & \\
\hline & & & & $\mathrm{za}$ & .70 & ns & & & \\
\hline & & & & spec & 14.73 & .001 & .33 & .48 & .50 \\
\hline & & & & pat & 1.90 & $\mathrm{~ms}$ & & & \\
\hline \multicolumn{10}{|c|}{ Exp/Kontr $x$ Resp } \\
\hline & 2.77 & 8,1078 & .01 & wkleid & .59 & ns. & & & \\
\hline & & & & $\mathrm{za}$ & 7.30 & .001 & & & \\
\hline & & & & & & $\exp$ & .75 & .78 & .89 \\
\hline & & & & & & kontr & .79 & .82 & .71 \\
\hline & & & & spec & 2.61 & ns & & & \\
\hline & & & & pat & .15 & $\mathrm{nS}$ & & & \\
\hline
\end{tabular}

* vrijheidsgraden bij univariate toetsen 'konditie': $\mathrm{df}=1,542$

wrijheidsgraden bij whivariate toetsen 'respondent' en 'respondent $x$ konditie': df $=2,542$

\section{De positie van de afzonderlijke groeperingen}

Hierna worden de machtsposities van de verschillende (groepen) personen besproken. Achtereenvoigens wordt ingegaan op de machtspositie van de verpleegkundige leiding, de arts (zaalarts/medisch specialist), de koördinerend hoofdverpleegkundige, de hoogleraar, de medische registratie-assistent en de patiënt.

De verpleegkundige leiding. De invloedspositie van de verpleegkundige leiding op experimentele verpleegeenheden verschilt naar de mening van de respondenten met de positie van de verpleegkundige leiding op de kontrole eenheden op een aantal aspekten. Wat de algemene invloed op de gang van zaken op de verpleegeenheid betreft, zijn er geen verschillen tussen de twee kondities (Tabel 7-1). Ten aanzien van de invloed van de verpleegkundige leiding op meer specifieke zorgaspecten blijkt dat 
deze, naar de mening van de verpleegkundigen, de verpleegkundige leiding en de artsen, op experimentele verpleegeenheden kleiner is dan op kontrole verpleegeenheden. (Tabel 7-2). Over de invloed op specifieke onderdelen in de patiëntenzorg werden aan de verpleegkundigen en de verpleegkundige leiding meer vragen gesteld dan aan de artsen. Bij de vragen die aan de verpleegkundige discipline werden voorgelegd konden twee invloedsdimensies onderscheiden worden (zie Bijlage V). Het blijkt dat op experimentele eenheden de invloed van de verpleegkundige leiding kleiner is wat de 'meer medische aspekten' betreft $(F[1,436]=28.50 ; \mathrm{p}<.001)$, maar niet wat de 'verpleegkundige aangelegenheden' betreft $(F[1,436]=.27$; ns). Gezien de inhoud van de items (Bijlage $V$ ) kan vastgesteld worden dat de verpleegkundige leiding op de experimentele eenheden aanzienlijk minder bemoeienis heeft met de direkte patiëntenzorg. Dit geldt niet voor de verpleegkundige organisatie en de verpleegkundige werkmethode.

De artsen en de verpleegkundigen hebben aangegeven hoe afhankelijk zij zijn van de verpleegkundige leiding bij het uitvoeren van de eigen werkzaamheden. Het blijkt dat artsen en verpleegkundigen zich op experimentele verpleegeenheden minder afhankelijk voelen van de leiding dan op kontrole eenheden: $F(1,483)=13.39, p<.001$; de gemiddelden bedragen respektievelijk 3.22 en 3.55. De verpleegkundigen, de leidinggevenden en de artsen van experimentele eenheden vinden tevens dat de verpleegkundige leiding in mindere mate zelfstandig beslissingen kan nemen en dat minder met de verpleegkundige leiding overlegd behoeft te worden alvorens beslissingen over specifieke aspekten van de patiëntenzorg genomen kunnen worden (Tabel 7-3 en 7-4). Wanneer we de vragen die alleen aan de verpleegkundige discipline werden voorgelegd bekijken (zie Bijlage IV), dan blijkt ook hier, dat de verpleegkundige leiding en de verpleegkundigen van experimentele eenheden van mening zijn dat de leiding in mindere mate zelfstandig kan beslissen en in mindere mate bij overleg betrokken wordt, voor zover het de direkte verzorging van patiënten betreft: $F(1,475)$ $=24.71, \mathrm{p}<.001$ en $\mathrm{F}(1,473)=24.46, \mathrm{p}<.001)$. De positie van de verpleegkundige leiding op experimentele eenheden in termen van 'het zelfstandig kunnen beslissen' en 'bet bij overleg betrokken worden', voor zover het specifiek verpleegkundige zaken betreft verschilt niet van de positie van de verpleegkundige leiding op de kontrole eenheden: $F(1,475)=.28$, ns en $F(1,473)=.17$, ns.

Vastgesteld kan worden, gelet op de hierboven beschreven resultaten, dat de positic van de verpleegkundige leiding op experimentele eenheden nogal verschilt van de positie van de verpleegkundige leiding op kontrole eenheden: de invloed op de patiëntenzorg is kleiner, de leiding wordt minder bij overleg betrokken, kan in mindere mate zelfstandig beslissingen nemen en artsen en verpleegkundigen voelen zich minder afhankelijk wan de leiding bij het uitvoeren van de eigen werkzaamheden. Opgemerkt moet echter worden dat wanneer het gaat om de invloed van de leidinggevende op de algemene gang van zaken op de eenheid, de invloed op verpleegkundige aangelegenheden, het kunnen nemen van beslissingen over verpleegkundige zaken en het bij overleg hierover betrokken worden, er geen werschillen worden gevonden tussen de twee kondities. Het voorgaande wijst er op dat de verpleegkundige leiding van experimentele eenheden minder invloed heeft op de verzorging van individuele patiënten maar niet op de verpleegkundige organisatie.

Naast de hiervoor beschreven verschillen in invloedspositie van de verpleegkundige 
leiding op experimentele en kontrole eenheden, blijken de drie groepen respondenten in beide kondities de invloedspositie van de werpleegkundige leiding verschillend te beoordelen. Het betreft hier de mate waarin de verpleegkundige leiding invloed heeft op specifieke zorgaspekten (Tabel 7-2) en bij overleg over de patiëntenzorg wordt betrokken (Tabel 7-4). Het blijkt dat de leiding de eigen invloed op de zorg hoger inschat dan artsen en verpleegkundigen $(p<.001)$. De artsen en verpleegkundigen verschillen onderling niet van mening over de mate waarin de leiding hier invloed op heeft. De leiding vindt tevens dat zij vaker bij overleg wordt betrokken dan dat artsen en verpleegkundigen van mening zijn dat de leiding bij overleg betrokken wordt $(p<.05)$. Ook hier verschillen de artsen en de verpleegkundigen onderling niet van mening. Het voorgaande wijst er op dat in beide kondities de leiding de eigen invloedspositie hoger inschat dan de andere twee groepen respondenten.

De artsen. Ten aanzien van de invloed van de artsen op de algehele gang van zaken en hun invloed op specifieke onderdelen van de zorg, blijken er geen verschillen tussen de twee kondities te zijn. De verpleegkundigen en de verpleegkundige leiding hebben aangegeven in welke mate zij in hun eigen funktioneren afhankelijk zijn van zaalartsen en medisch specialisten. Ook hier wordt geen verschil tussen de twee kondities gevonden: $F(2,465)=2.14$, ns. Er blijkt wel een verschil tussen de twee kondities voor wat betreft de mate waarin artsen volgens de drie groepen respondenten zelfstandig beslissingen kunnen nemen en de mate waarin zij bij overleg betrokken worden. Het blijkt dat zaalartsen op experimentele eenheden meer zelfstandig beslissingen kunnen nemen. Dit echter alleen naar de mening van de arts $(p<.001)$ en niet naar de mening van verpleegkundigen en de verpleegkundige leiding (Tabel 7-3 en Figuur 7-1.). Wel vinden alle drie groepen respondenten, dat de zaalarts minder bij overleg over specifieke onderdelen van de zorg wordt betrokken op experimentele eenheden (Tabel 7-4).

Ook de patiënten is gevraagd de invloedspositie van artsen te beoordelen. Eerder kwam in deze studie naar voren dat patiënten van experimentele eenheden meer eigen invloed op de zorg percipiëren dan patiënten van kontrole eenheden. Ten aanzien van de door patiënten waargenomen invloed van artsen, is er zowel 'na opname' als 'voor ontslag' geen verschil tussen de twee kondities: $F(1,340)=.15$, ns en $F(1,340)=.14$, ns.

Vastgesteld moet worden dat de invloedspositie van artsen op experimentele eenheden niet sterk afwijkt van hun positie op kontrole eenheden. Ten aanzien van de invloedspositie van de specialist zijn er in het geheel geen verschillen gevonden. De zaalarts wordt wat minder bij overleg betrokken. De artsen vinden echter zelf dat zij op experimentele eenheden meer zelfstandig kunnen beslissen.

Naast de hiervoor beschreven verschillen tussen de machtspositie van artsen op experimentele en kontrole eenheden, blijkt dat de drie groepen respondenten in beide kondities van mening verschillen over de machtspositie van artsen. Het blijkt dat artsen de invloed van de zaalarts op de algehele gang van zaken op de eenheid hoger inschatten dan verpleegkundigen $(\mathrm{p}<.05)$, die op hun beurt de invloed van de zaalarts groter vinden dan de verpleegkundige Jeiding $(\mathrm{p}<.01$, zie Tabel $7-1)$. De invloed van 


\section{MATE WAARIN ZAALARTS ZELFSTANDIG KAN BESLISSEN}

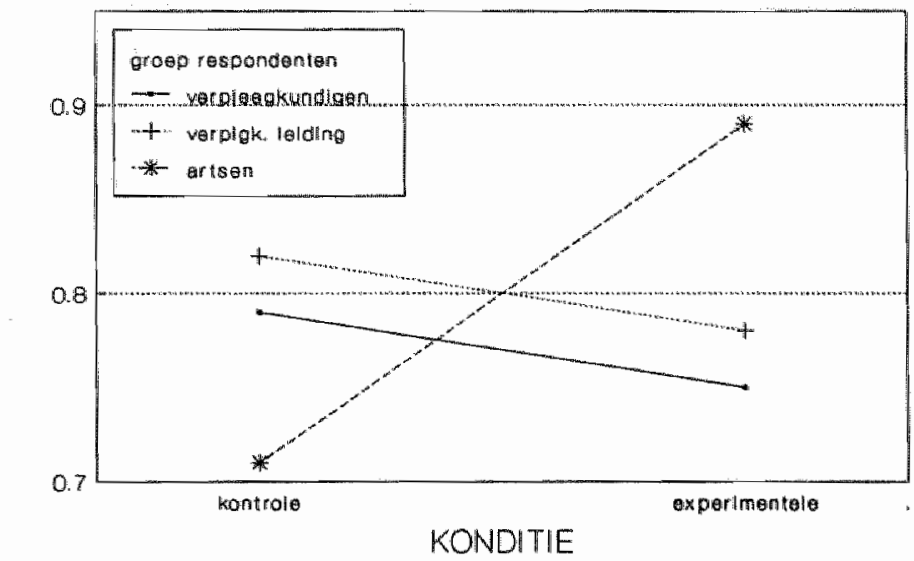

Srange o tot th

Figuur 7-1: De mate waarin zaalartsen volgens verpleegkundigen, de verpleegkundige leiding (verplgk. leiding) en artsen op kontrole en op experimentele verpleegeenheden zelfstandig beslissingen kunnen memen.

de zaalarts op specifieke zorgaspecten wordt door artsen wat kleiner ingeschat dan door verpleegkundigen $(p<.05$, Tabel 7-2). Deze laatsten verschillen hierover niet van mening met de verpleegkundige leiding. Verder blijkt dat de verpleegkundigen zich over het geheel genomen meer afhankelijk voelen van de zaalarts bij het uitvoeren van de eigen werkzaamheden dan de verpleegkundige leiding.: $\mathrm{F}(1,466)=6.53, \mathrm{p}<.05$; de gemiddelden bedragen respektievelijk 3.36 en 3.04. Tenslotte blijkt dat de verpleegkundige leiding vindt dat de zaalarts meer bij overleg wordt betrokken dan dat de artsen en de verpleegkundigen dat vinden: $\mathrm{p}<.05$; zie Tabel $7-4$.

Over de machtspositie van de specialist verschillen de drie groepen respondenten onderling niet erg sterk van mening. Het blijkt dat verpleegkundigen in mindere mate vinden dat de specialist zelfstandig beslissingen kan nemen $(p<.001)$ en minder bij overleg wordt betrokken $(\mathrm{p}<.01)$ dan volgens de verpleegkundige leiding en de artsen (Tabel 7-3 en 7-4). Het lijkt er op dat verpleegkundigen de positie van de arts relatief wat zwakker vinden dan de arts. Dit in termen van 'invloed op de algehele gang van zaken, 'het betrokken worden bij overleg' en 'het nemen van beslissingen'. De verpleegkundigen voelen zich wanneer dit vergeleken wordt met de mening van de leiding, meer afhankelijk van de arts. De leiding vindt dat de arts relatief weinig invloed heeft op de algehele gang van zaken, maar dat artsen relatief in grote mate zelfstandig kunnen beslissen en veel bij overleg worden betrokken. 
Tobel 74. De mate warnin de verpleegkundige leíding (vkleid), de zaalarts (za), de medisch specialisit (spec) ten de patient (pat) bij oxerleg over een aanial specifieke onderdelen van de werzorging worden betrokken. Als faktoren zijn in het ontwerp opgenomen de konditie (exp/kontr) en de groep respondenten (resp): verpleegkundigen (wk), de verpleegkundige leiding (wkleid) en de artsen (arts).

\begin{tabular}{|c|c|c|c|c|c|c|c|c|c|}
\hline \multirow[t]{2}{*}{ Bron } & \multirow[b]{2}{*}{$\mathrm{F}$} & \multicolumn{2}{|c|}{ Multiwariaat } & \multicolumn{2}{|c|}{ Univariaal } & \multirow[b]{2}{*}{$\mathrm{p}<$} & \multicolumn{3}{|c|}{ Gemiddelden } \\
\hline & & $d f$ & $p<$ & variabele & $\mathbb{E}^{*}$ & & & & Kontr \\
\hline \multicolumn{10}{|c|}{ Exp/Kontr } \\
\hline & 7.34 & 4.537 & .001 & vikleid & 19.08 & .001 & & & .54 \\
\hline & & & & $2 a$ & 12.26 & .001 & & & .71 \\
\hline & & & & spec & .20 & $\mathbf{n s}$ & & & \\
\hline & & & & pat & 1.09 & ns & & & \\
\hline & & & & & & \multicolumn{4}{|c|}{ vk vkleid } \\
\hline \multirow[t]{4}{*}{ Resp } & 5.57 & 8,1074 & .001 & wkleid & 4.45 & .05 & .48 & .62 & .49 \\
\hline & & & & & 6.65 & .01 & .65 & .82 & .65 \\
\hline & & & & spec & 14.82 & .001 & .33 & .5 & .48 \\
\hline & & & & pat & 3.92 & .05 & .61 & .7 & 63 \\
\hline
\end{tabular}

Exp/Kontr $x$ Resp

$.96 \quad 8,1074 \quad$ ns

" vrijheidsgraden bij univariate toetsen 'konditie': $\mathrm{df}=1,540$

vilifheidsgraden bif uniwariate toetsen 'respondent": $d f=2,540$

De koördinerend hoofdverpleegkundige. De drie groepen respondenten hebben de invloed van de koördinerend hoofdverpleegkundige (CHV) op de algehele gang van zaken op de verpleegeenheid beoordeeld, alsmede aangegeven hoe afhankelijk zij van hem/haar zijn bij het uitvoeren van de eigen werkzaamheden. Het blijkt dat de invloed van de CHV op de experimentele eenheden groter wordt gevonden dan op de kontrole eenheden (Tabel 7-1). Er wordt geen verschil in 'afhankelijkheid' gevonden: $F(1,509)$ $=.10, \mathrm{~ns}$.

In belde kondities verschillen de drie groepen respondenten onderling van mening over de invloed van de CHV op de algehele gang van zaken. De verpleegkundige leiding vindt de invloed van de CHV kleiner dan de andere twee groepen respondenten $(\mathrm{p}<.001)$, die onderling hierover niet van mening verschillen.

De hoogleraar. De invloedspositie van de hooglera(a)r(en) wordt in beide kondities niet verschillend beoordeeld (Tabel 7-1). Dit geldt ook voor de mate waarin men zich afhankelijk voelt van de hoogleraar: $\mathrm{F}(1,509)^{\circ}=.00$, ns. Wel denken de drie groepen respondenten in beide kondities verschillend over de invloedspositie van de hoogleraar. De leiding schat de invloed van de hoogleraar op de algehele gang van zaken op de eenheid wat lager in dan de andere twee groepen respondenten $(\mathrm{p}<.05)$. De artsen voelen zich meer afhankelijk van de hoogleraar dan de verpleegkundigen en de verpleegkundige leiding: $F(2,509)=8.63, p<.001$; de gemiddelden bedragen respektievelijk $2.76,2.10$ en 2.00 . 
De medische registratie-assistent. Het bljikt dat de positie van de medische registratieassistent (regas) in de beide kondities nogal verschillend wordt beoordeeld, $O_{p}$ de experimentele eenheden wind men dat de regas meer invloed heeft op de algehele gang vam zaken dan op de kontrole eenheden (Tabel 7-1). Tevens vinden de respondenten van de experimentele eenheden dat zij meer afhankelijk zijn van de regas bij het uitvoeren van de eigen werkzaamheden: $F(1,509)=15.87, p<.001$.

Naast de verschillen tussen de twee kondities, blijkt dat in beide kondities de drie groepen respondenten de positie van de regas verschillend beoordelen. Het blijkt dat de artsen de invloed van de regas op de algehele gang van zaken groter vinden dan de andere twee groepen respondenten $(\mathrm{p}<.001)$. De verpleegkundigen voelen zich minder afhankelijk van de regas dan de artsen: $F(2,509)=12.04, p<.001$. De gemiddelden bedragen voor de verpleegkundigen, de leiding en de artsen respektievelijk $2.38,2.72$ en 3.05 .

De patiënt. In hoofdstuk 5 kwam naar voren dat patiënten van experimentele eenheden meer invloed percipiëren dan patiënten van kontrole eenheden. Ook de andere drie groepen respondenten hebben de invloedspositie van de patiënt beoordeeld. Het blijkt dat naar de mening van de drie groepen respondenten de invloedspositie van de patiënt in de twee kondities niet verschilt (Tabel 7-2 tot en met 7-4). Wel blijken de drie groepen respondenten in beide kondities onderling van mening te verschillen over de invloed van de patiënt. De verpleegkundige schat de invloed van de patiënt op de zorg lager in dan de andere twee groepen respondenten $(p<.001$, Tabel 7-2). Verder blijkt dat de leiding meer dan de andere respondenten vindt, dat patiënten bij overleg over de zorg worden betrokken $(p<.05$, Tabel 7-4).

\section{Groeiende koek.}

Per respondent kan een somscore gekonstrueerd worden van de door hem/haar waargenomen invloed van de verpleegkundigen, de leiding, de zaalarts, de medisch specialist en de patiënt tezamen. Dit kan gedaan worden voor de invloed op specifieke zorgaspekten, de invloed op de algehele gang van zaken op de eenheid, de mate waarin zelfstandig beslissingen genomen kunnen worden en de mate waarin men bij overleg wordt betrokken. Het blijkt dat de drie groepen respondenten van experimentele eenheden niet meer invloed percipiëren dan de respondenten van de kontrole eenheden: $F(4,492)=.75$, ns. Het lijkt er op dat de totaal waargenomen macht op de experimentele eenheden niet verschilt van de totaal waargenomen macht op kontrole eenheden. Dit wijst er op dat de 'groeiende koek' hypothese niet wordt ondersteund. Integrerende verpleegkunde lijkt vooral verschuivingen in de machtsposities binnen de verpleegkundige discipline (verpleegkundigen en de verpleegkundige leiding) te veroorzaken en met name ten aanzien van de direkte patiëntenzorg. De posities van de andere groeperingen, behalve die van de medische registratie-assistent en de patiênt, verschillen in de beide kondities niet of nauwelijks van elkaar.

Alvorens het voorgaande samen te vatten, is het zinvol in het kort stil te staan bij de gepercipieerde machtsverhoudingen tussen de diverse groeperingen. Dit gebeurt tan de hand van enkele figuren (Figuur 7-2 tot en met 7-4). Wanneer gekeken wordt naar de invloed op de algehele gang van zaken op de verpleegeenheid, dan blijkt dat deze 
vooral in handen is van de verpleegkundige discipline. Het besturen van de verpleegeenheid is met name een zaak van de verpleegkundigen. Artsen en met name de zaalartsen hebben de meeste inwloed op de direkte patiëntenzorg en kunnen het meest zelfstandig beslissen over specifieke onderdelen wan de patiëntenzorg. Het blijkt echter dat men zich bij het uitvoeren van de eigen werkzaamheden relatief afhankelijk voelt van de verpleegkundige discipline. Deze discipline wordt ook relatief vaak bij overleg betrokken, al geldt dit ook voor de zaalarts en de patiënt. Terwijl de (zaal)arts relatief vaak de beslissingen in de zorg neemt, wordt met de verpleegkundigen en de patiënt vaak overlegd voordat beslissingen genomen worden.

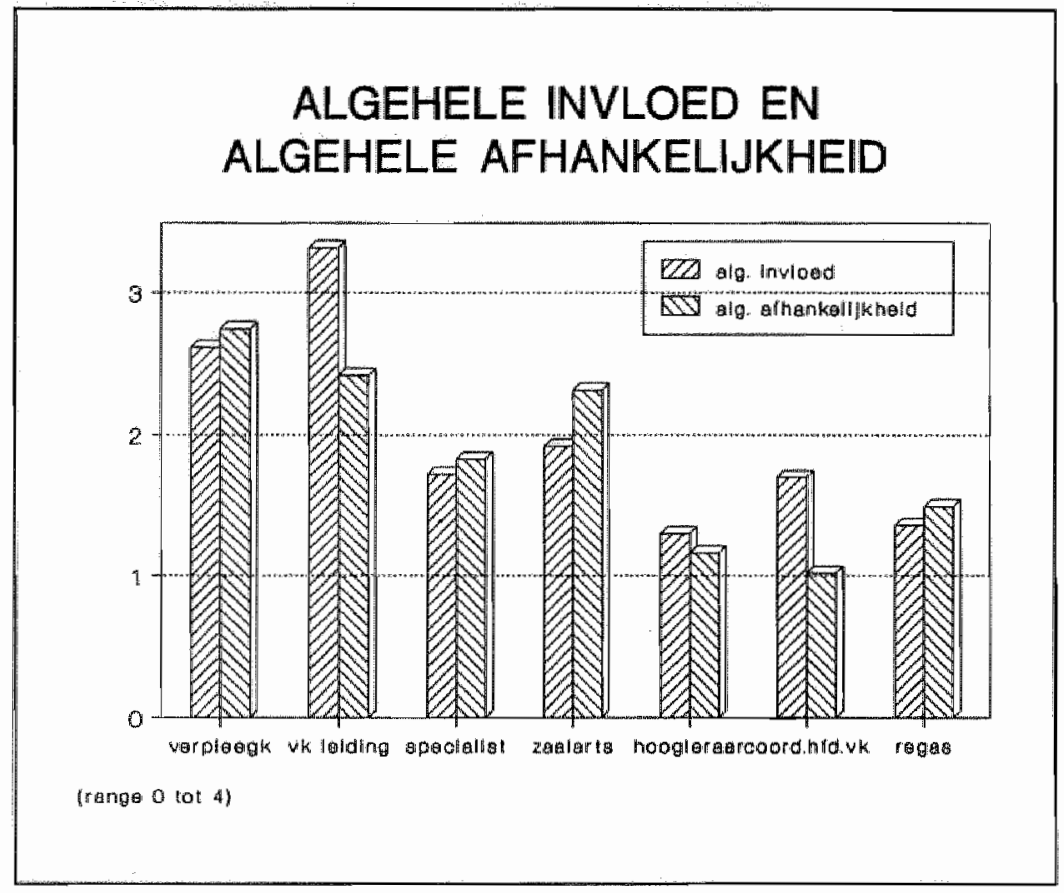

Figutu 7.2. De mate waarin werpleegkundigen (verpleegk), de verpleegkundige leiding (vk leiding), de specialist, de zaalarts, de hoogleraar, de koordinerend hoofdverpleegkundige (coord.hfd.vk) en de medische registratie-assistent (regas) invloed hebben op de algehele gang van zaken op de verpleegeenheid en de mate waarin de respondenten winden dat zij over het algemeen afhankelijk zijn van deze zeven (groepen) personen bij het verrichten van de eigen werkzaamheden.

\subsection{Samenvatting en Diskussie}

De verwachting dat verpleegkundigen hun machtspositie zouden versterken ondervond ondersteuning (hoofdstuk 6). De mogelijkheid werd geopperd (hoofdstuk 3), dat de totaal waargenomen macht kan groeien, zodat de vergroting van de macht van 
de eén niet ten koste hoeft te gaan van de machtspositie van een ander. De 'totaal waargenomen macht', blijkt echter niet te zijn toegenomen. Het blijkt dat de introduktie van Integrerende Verpleegkunde invloed heeft gehad op de positie van enkele andere groepen personen. Hierna worden de gevolgen voor de verschillende groeperingen in het kort besproken.

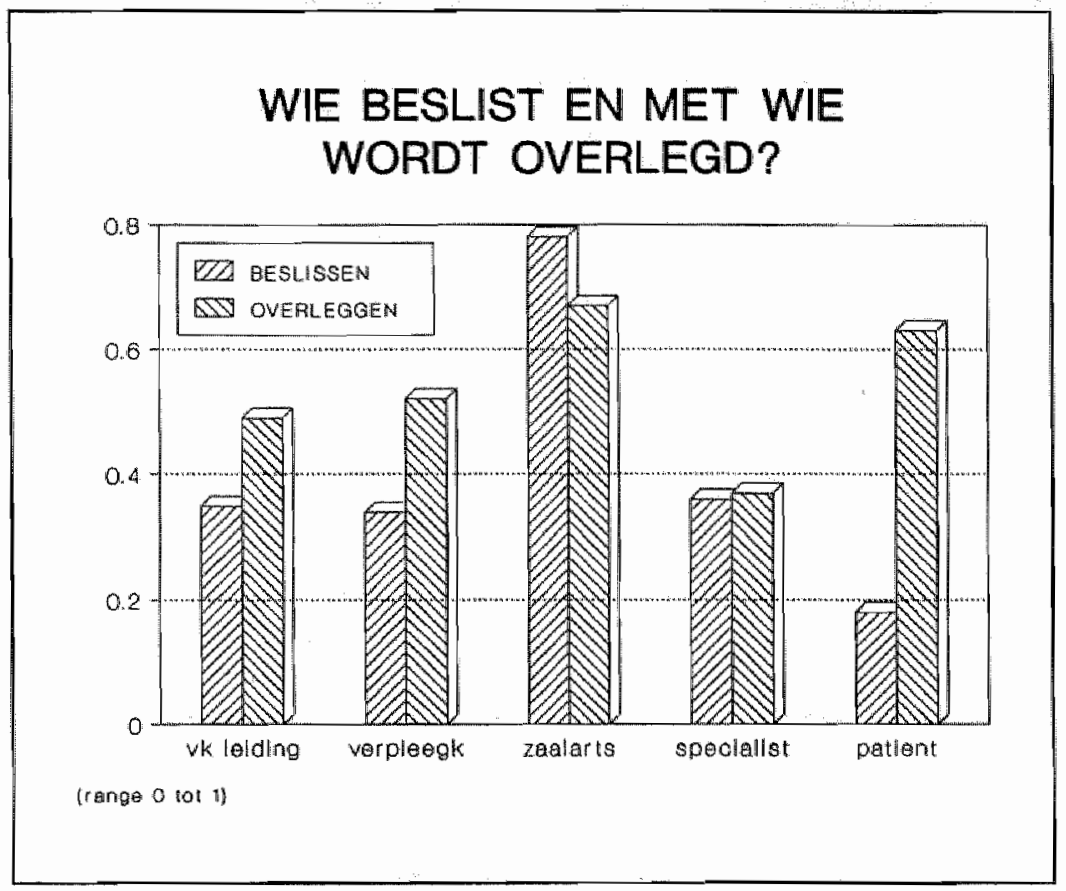

Figuur 7-3. De mate waarin de verpleegkundige leiding (vk leiding), de verpleegkundigen (verpleegk), de zaalarts, de specialist en de patiént zelfstandig beslissingen kunnen nemen in de patiěntenzorg en de mate waarin deze vijf (groepen) personen volgens de respondenten bij overleg in de patientenzorg worden betrokken.

De verpleegkundige leiding. Wanneer gekeken wordt naar de machtspositie van andere kategorieën personen, dan kan worden vastgesteld dat wat de verschillen tussen kontrole en experimentele konditie betreft, deze met name te vinden zijn bij de verpleegkundige leiding. Het blijkt dat op experimentele eenheden de leiding volgens de drie groepen respondenten minder invloed heeft op de directe patiëntenzorg, minder zelfstandig beslissingen kan nemen over onderwerpen die de directe patiëntenzorg betreffen en ook veel minder bij overleg over onderwerpen die de directe patiëntenzorg betreffen wordt betrokken. De verpleegkundigen en de artsen voelen zich op experimentele eenheden bovendien minder afhankelijk van de verpleegkundige leiding bij het uitvoeren van de eigen werkzaamheden in de patiëntenzorg. De invloed van de leiding op de meer beleidsmatige zaken is op de experimentele eenheden niet kleiner. 
Het blijki overigens dat op zowel de experimentele als de kontrole eenheden de verpleegkundige leiding verreweg de belangrijkste persoon is, wanneer het gaat over de meer organisatorische en beleidsmatige aangelegenheden. Het betreft taken die niet de directe patientenzorg betreffen.

De medische registratie-assistent. Het blijkt dat men zich op experimentele eepheden meer afhankelijk voelt van de medische registratie-assistent dan op kontrole eenheden. Met name artsen voelen zich meer afhankelijk van hen. De drie groepen respondenten vinden echter dat de medische registratie-assistent niet meer invloed heeft op de verzorging en behandeling van patiënten. De medische registratie-assistent heeft over het algemeen een vaste werkplek op de eenheid. Meestal achter een balie die mensen, die de eenheid opkomen of verlaten, passeren. Via de medische registratie-assistent komt veel telefonische informatie de eenheid binnen van bijwoorbeeld laboratoria, röntgenafdelingen, apotheek of familie van de patiënt. Zij of hij heeft vaak zicht op wie op een bepaald moment op de eenheid aanwezig is en waar personen zich bevinden. Het is in die zin begrijpelijk dat met name artsen die frequent voor korte duur op de eenheid zijn, de medische registratie-assistent als vraagbaak zien ("is patiënt $\mathrm{A}$ al terug van onderzoek B?", "zijn de uitslagen voor patiënt $\mathrm{C}$ al binnen?", "waar kan ik verpleegkundige $\mathrm{D}$ vinden?" enz.). Omdat de koördinatie van de verpleegkundige zorg niet meer bij de verpleegkundige leiding is gelegen maar bij de afzonderlijke verpleegkundigen, is het aannemelijk dat artsen de medische registratie-assistent op experimentele eenheden sterker als een koördinatiepunt voor informatie zijn gaan beschouwen. De verpleegkundige leiding -in de beleving van artsen traditioneel de centrale spil in de uitvoering van de verpleegkundige patiëntenzorg-- weet immers niet meer "hoe het met de medicatie van patiënt $A$ is gesteld" of "patiënt B nog gedeprimeerd is".

De arts. De positie van de arts lijkt door Integrerende Verpleegkunde niet of nauwelijks veranderd. De (zaal)arts is, in zoverre het de directe patiëntenzorg betreft, in beide kondities naar de mening van de respondenten de meest invloedrijke persoon. Het blijkt dat de artsen van mening zijn dat zij op experimentele eenheden vaker de uiteindelijke beslissing nemen over specifieke patiëntenzorg aspekten. Daar staat tegenover dat de drie groepen respondenten vinden dat de zaalarts minder bij overleg wordt betrokken. Zaalartsen zijn medische specialisten in opleiding. Zij werken meestal gedurende 3 tot 6 maanden op een verpleegeenheid. Hoewel artsen gemiddeld een hogere status hebben dan verpleegkundigen, zal dit niet of in veel mindere mate gelden woor een arts die aan het begin staat van zijn of haar specialistische opleiding. De expertise van ervaren verpleegkundigen zal op veel gebieden (ook medische) niet voor de deskundigheid van een arts, die met zijn of haar specialistische opleiding begint onderdoen. De zaalarts is relatief veel op de verpleegeenheid aanwezig en heeft er dan ook belang bij goede relaties te onderhouden met verpleegkundigen. De specialist heeft een meer duurzame maar minder intensieve werkrelatie met een verpleegeenheid. Hij of zij is over het algemeen veel minder frekwent anwezig op de eenheid. De specialist heeft zonder twijfel meer status en meer expertise dan verpleegkundigen. Terwijl verpleegkundigen in hun funktioneren vooral afhankelijk zijn van de verpleegkundige leiding en van artsen, zijn zaalartsen met name afhankelijk van de medische staf (medisch specialisten en hoogleraren) en van verpleegkundigen. De specialist is veel 


\section{INVLOED OP DE ZORG}

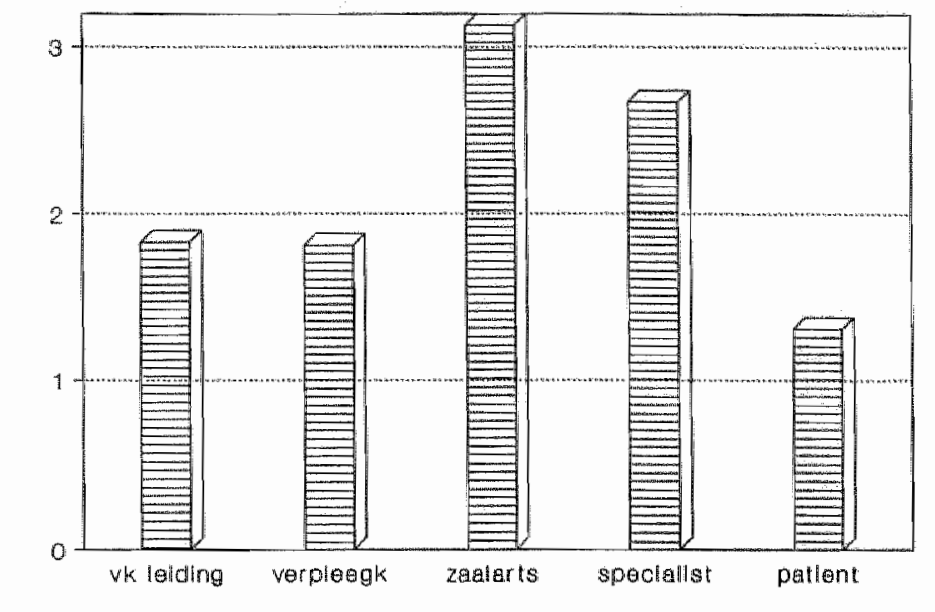

(riange o to: 4)

Figuur 7-4. De mate waarin de verpleegkundige leiding (vk leiding), de verpleegkundigen (verpleegk), de zaalarts, de specialist en de patient invloed hebben op de patientenzorg.

minder afhankelijk van verpleegkundigen. Het is dan ook niet verwonderlijk dat veranderingen in de verpleegkundige organisatie geen invloed hebben op de positie van de specialist. Zeven (zaal)artsen van de experimentele eenheden zijn in een interview nader bevraagd over hun ervaringen. Uit hun reakties komt naar voren dat zij met name klagen over de tijd die ze moeten besteden aan het opsporen van de verpleegkundige die verantwoordelijk is voor een specifieke patiënt. In die zin is het verklaarbaar dat zij vinden dat zij meer met verpleegkundigen moeten overleggen en toch van mening zijn dat zij minder bij overleg worden betrokken. Wanneer artsen de betreffende verpleegkundige niet (snel genoeg) kunnen vinden zullen zij toch beslissingen moeten nemen. Mogelijk dat hierdoor zaalartsen van mening zijn dat zij op experimentele eenheden meer zelfstandig kunnen (of moeten) beslissen. Daarnaast is het mogelijk dat het meer zelfstandig beslissen door de zaalarts niet zozeer betrekking heeft op de werkrelatie met de verpleegkundigen maar op de samenwerking met de medische staf. Gekonkludeerd kan worden dat de positie van de arts nauwelijks is weranderd. 



\section{HOOFDSTUK 8 DISKUSSIE EN KONKLUSIES}

In dit laatste hoofdstuk zal een nadere beschouwing worden gegeven van de vraagstellingen, de opzet en de resultaten van de studie. In de eerste paragraaf zullen de resultaten kort worden samengevat. In de tweede paragraaf zullen enkele methodologische kanttekeningen worden gemaakt. Hierbij zal achtereenwolgens aandacht besteed worden aan de mate waarin diffusie van de twee kondities de resultaten kan hebben beïnvloed en de mate warin binnen de kontrole konditie, elementen van Integrerende Verpleegkunde zijn geïntroduceerd (imitatie/kontaminatie, zie bijvoorbeeld Cook \& Campbell, 1979). Verder zall aandacht besteed worden aan de 'reaktiviteit' van de onderzoekssituatie. 'Reaktiviteit' refereert aan een situatie waarin de onderzochten zich er bewust van zijn dat zij aan een onderzoek deelnemen (Orne, 1969). Dit kan het gedrag van de respondenten beïnvloeden, zeker indien aan de hand wan vragenlijsten gevraagd wordt naar --de mening over-- dit gedrag. In de derde plaats zall aandacht besteed worden aan de mogelijkheid dat de resultaten zijn beïnvloed door 'selektie'. 'Selektie' houdt in dat de gevonden verschillen tussen de twee kondities (mede) zijn te verklaren door non-equivalentie ten aanzien van één of meerdere faktoren waarop de twee kondities bij aanvang van het experiment verschillen.

In de derde paragraaf zullen de resultaten vanuit een theoretisch perspektief worden belichten. Ook zullen enkele praktische konklusies worden geformuleerd.

\subsection{Overzicht van de resultaten}

Het model Integrerende Verpleegkunde onderscheidt zich van taakgericht of funktioneel verplegen door patiënttoewijzing en de methode van 'het systematisch verpleegkundig handelen'. Het is gebleken dat binnen de experimentele verpleegeenheden meer volgens het onderzochte model wordt gewerkt dan binnen kontrole verpleegeenheden. De verschillen tussen de twee kondities zijn ten aanzien van patiënttoewijzing redelijk groot. Wat 'het systematisch verpleegkundig handelen' betreft, zijn de verschillen klein.

Verwacht werd dat de introduktie van het model, gevolgen zou hebben voor patiënten, de verpleegkundige beroepsgroep en mogelijk ook voor andere leden van de ziekenhuisorganisatie. De resultaten zullen voor deze drie groepen afzonderlijk worden samengevat.

\section{De patiënt}

Omdat patiënten met minder verschillende verpleegkundigen in kontakt komen en nauw bij de verpleegkundige zorg worden betrokken, werd verwacht dat patiënten meer invloed op het verblijf in het ziekenhuis zouden gaan ervaren. Het blijkt dat patienten van experimentele eenheden ervaren dat zij meer invloed hebben op de planning van de zorg en de wijze waarop zij begeleid worden (hypothese 1).

Verwacht werd, dat indien patiënten meer invloed zouden ervaren, zij zich ook 
meer verantwoordelijk zouden gaan voelen voor de resultaten van de verzorging en de behandeling in het ziekenhuis en meer invloed zouden gaan ervaren op de eigen gezondheidstoestand in het algemeen (hypothese 2). Deze verwachting werd niet bevestigd.

Verder werd verondersteld dat patiênten meer initiatief zouden gaan nemen, zich meer 'probleemoplossend' zouden gaan opstellen, beter geïnformeerd zouden zijn en meer zelfzorgaktiviteiten zouden ontplooien (hypothese 3). Het blijkt, wanneer de meningen van patiënten uit de twee kondities met elkaar worden vergeleken, dat patiênten uit de experimentele konditie alleen meer zelfzorgaktiviteiten zeggen te verrichten. Op de drie andere aspekten worden geen verschillen gevonden.

In de vierde hypothese werd voorspeld dat de verschillen tussen de twee kondities groter zouden zijn naarmate patiënten langer in het ziekenhuis verblijven. Het blijkt dat naarmate de opname langer duurt, het verschil tussen de twee kondities alleen toeneemt ten aanzien van het verrichten van zelfzorgaktiviteiten.

De viffde hypothese handelt over de betekenis van de verwachting van een patiënt bij opname, over zijn of haar mogeljikheden zelf invloed uit te kunnen oefenen op het verblijf in het ziekenbuis. Verwacht werd dat patiënten met hoge initiële verwachtingen, binnen de experimentele konditie weinig en binnen de kontrole konditie veel stress zouden gaan ervaren. Deze verwachting werd niet bevestigd. In een secundaire analyse kwam naar voren dat patiënten die bij opname verwachten dat de arts, de verpleegkundige en de patiënt tezamen veel invloed hebben, op experimentele eenheden minder stress ervaren dan op kontrole verpleegeenheden.

\section{De verpleegkundigen}

Verwacht werd dat Integrerende Verpleegkunde een aantal gunstige gevolgen zou hebben voor de positie van de verpleegkundige professie binnen de ziekenhuisorganisatie. Meer specifiek werd verwacht dat verpleegkundigen een ruimere taak zouden krijgen (hypothese 1) en indien zij deze zouden weten uit te voeren, zij hun machtspositie in de organisatie zouden kunnen versterken (hypothese 2). Beide hypothesen worden door het verzamelde materiaal ondersteund.

In hypothese 3 werd naar voren gebracht dat enkele kondities het versterken van de machtspositie zouden bevorderen. In de beleving van artsen en de verpleegkundige leiding, draagt het adekwaat uitvoeren van de verpleegkundige werkzaamheden en een koöperatieve houding van verpleegkundigen, bij tot het versterken van de machtspositie. Verpleegkundigen zelf associëren meer invloed vooral met bekwaamheid en met het zich gebonden achten aan de realisering van verpleegkundige innovaties. De respondenten bleken de invloedspositie niet te relateren aan een aantal ander kondities, zoals de senioriteit van verpleegkundigen. De hypothese werd deels bevestigd. Uit een secundaire analyse kwam naar voren dat verpleegkundigen van experimentele eenheden meer negatief worden beoordeeld door artsen, dan hun kollega's van kontrole eenheden. Een mogelijke verklaring hiervoor werd gevonden in de bevinding, dat op de experimentele eenheden het de artsen meer tijd kost om met individuele verpleegkundigen te overleggen. Dit wordt door hen als onprettig ervaren.

verondersteld werd dat de taakverruiming weliswaar een gunstige invloed zou hebben op de machtspositie van verpleegkundigen in de organisatie, maar dat dit voor een individuele verpleegkundige ook ongewenste gevolgen met zich mee zou kunnen 
brengen. Verwacht werd dat indien een verpleegkundige de ruimere taak niet aan zou kunnen, zij meer onzekerheid zou gaan ervaren. Dit zou met name gelden voor verpleegkundigen met weinig ervaring of met een lager opleidingsnivo (hypothese 4). Interkollegiale ondersteuning werd gezien als een manier om de onzekerheid te reduceren. Verwacht werd dat de behoefte aan onderling overleg groter zou züjn, naarmate de verpleegkundige zelf, en haar kollega's, overleg als instrumenteel zien woor het reduceren van deze onzekerheden en naarmate een verpleegkundige de indruk heeft dat kollega's vergelijkbare onzekerheden ervaren (hypothese 5). Opleiding bleek niet gerelateerd aan het ervaren van onzekerheid en senioriteit bleek enige negatieve samenhang met onzekerheid te vertonen. Hypothese 4 wordt daarmee maar voor een deel ondersteund. Het bleek verder dat verpleegkundigen van experimentele eenheden niet meer onzekerheid ervaren in hun werk dan verpleegkundigen uit de kontrole konditie. Zij hebben ook geen grotere behoefte aan overleg. De behoefte aan overleg bleek verder niet gerelateerd aan de mate waarin men overleg als instrumenteel ziet voor het verminderen van onzekerheid en aan de mate waarin men verwacht dat kollega's vergelijkbare problemen in hun werk ervaren. Hypothese 5 ondervindt geen ondersteuning. Uit het verzamelde materiaal kwam wel naar voren dat het recentelijk hebben overlegd met kollega's, samengaat met het ervaren van weinig onzekerheid.

\section{Andere groeperingen}

Het bleek dat de respondenten uit de twee kondities de gezamenlijke invloed van diverse kategorieën personen niet verschillend inschatten. In beide kondities is de (zaal)arts de meest invloedrijke persoon wanneer het de direkte patiëntenzorg betreft en de verpleegkundige leiding wanneer het gaat om het beleid van de verpleegeenheid. Op de experimentele eenheden is de bemoeienis van de verpleegkundige leiding met de direkte patiëntenzorg aanzienlijk kleiner dan op kontrole eenheden. De positie van de arts is in de twee kondities ongeveer gelijk. Artsen ervaren wel een grotere afharkelijkheid van verpleegkundigen als het gaat om bijvoorbeeld het verkrijgen van informatie over de verzorging van een specifieke patiënt en de betreffende verpleeg. kundige is niet snel te bereiken. De medische registratie-assistent wordt mogelijk hierdoor, vooral in de beleving van artsen, vaker over deze onderwerpen aangesproken.

\subsection{Methodologische evaluatie}

\section{Diffusie en kontaminatie}

Het experiment met Integrerende Verpleegkunde op vier verpleegeenheden van het Academisch Ziekenhuis Groningen, heeft waarschijnlijk al gedurende en mogelijk zelfs al vóór aanvang van het onderzoek invloed gehad op verpleegkundigen van andere verpleegeenheden van het ziekenhuis. Er bestaan tevens aanwijzingen dat tijdens het experiment ook de houding van de verpleegkundige beroepsgroep in het land een sterke ontwikkeling heeft doorgemaakt. Deze ontwikkelingen hebben mogelijk het verloop van het experiment beïnvloed. Ook de mogelijkheid dat het experiment de landelijke ontwikkelingen heeft beïnvloed, moet niet uitgesloten worden.

Al in de jaren ' 80 en ' 81 heeft een werkgroep bestaande uit een tiental verpleegkundigen in het ziekenhuis zich verdiept in diverse verpleegkundige manieren van 
werken. Dit heeft geresulteerd in een rapport waarin gepleit wordt voor de introduktie wan het model Integrerende Verpleegkunde. In de 2 daarop volgende jaren werden onder andere door middel van een aantal bijeenkomsten, alle verpleegkundigen wan het ziekenhuis geinformeerd over de inhoud van dit rapport. Op grond van de reakties uit de organisatie werden de voorstellen bijgesteld en werd vervolgens de direktie van het ziekenhuis om toestemming gevraagd het model in te mogen voeren. In het kader van het experiment verschenen ruim veertig rapporten en verslagen van verpleegkundigen, die hun ervaringen met specifieke onderdelen wan het model beschreven, zoals de rol van de verpleegkundige leiding, het aanpassen wan het dienstrooster, veranderingen in de verpleegkundige rapportage en het afschaffen van taakgerichte aktiviteiten zoals de 'medicijin dienst'. Naar schatting zijn enkele duizenden van deze verslagen binnen het ziekenhuis en daarbuiten verspreid. Ruim de helft van deze rapporten verscheen vóordat het verzamelen van de onderzoeksgegevens werd beëindigd. Diverse malen werden gedurende het experiment, groepen verpleegkundigen van binnen en buiten het ziekenhuis ontvangen, die met het verpleegkundig model wilden kennismaken. Ook werden lezingen gehouden en verschenen er berichten in de pers over het experiment. Op grond van het voorgaande is het waarschijnlijk dat de kontrole eenheden de gelegenheid hebben gehad en genomen om ook elementen van Integrerende Verpleegkunde op de eigen eenheid te introduceren.

Op twee manieren zal nagegaan worden of het verzamelde materiaal aanwijzingen kan geven voor deze kontaminatie. In de eerste plaats zal nagegaan worden of naast de gevonden verschillen tussen de twee kondities er lopende het onderzoek ook veranderingen in beide kondities hebben plaatsgevonden. Het onderzoeksmateriaal werd verzameld gedurende drie meetmomenten (mei/juni " 84 , november/december '84 en mei/jun' ' 85 ). Nagegaan zal worden of er verschillen bestaan (in beide kondities) tussen de drie meetmomenten.

In het kader van de selektie van de experimentele verpleegeenheden, hebben de leidinggevenden van alle verpleegeenheden van het ziekenhuis aangegeven in welke mate de eigen eenheid geschikt zou zijn voor de intraduktie van Integrerende Verpleegkunde. De leidinggevenden beoordeelden hun eenheid op een dertiental kondities. De resultaten werden beschreven in hoofdstuk 4. Deze 13 kondities werden na afloop wan het experiment opnieuw aan alle leidinggevenden van het ziekenhuis voorgelegd. In de tweede plaats wordt nagegaan in welke mate leidinggevenden de eigen eenheid in november ' 85 geschikt achten en dit vergelijken met hun mening wór alanvang van het experiment (mei '83). Indien de kondities in het gehele ziekenhuis zijn verbeterd, is het aannemelijk dat dit mede het gevolg is van het experiment.

Verschillen tussen de meetperiodes. In hoofdstuk 5 bleek dat er op de experimentele verpleegeenheden meer sprake is van patiënttoewijzing dan op kontrole eenheden. Deze vragen werden gedurende de tweede en derde periode aan de patiënten en verpleegkundigen voorgelegd (zie 5.4). Wanneer deze twee meetperiodes als faktor in een variantie-analyse worden opgenomen, dan blijkt dat de mate van patiënttoewijzing tijdens de derde periode hoger is dan tijdens de tweede periode: $F(1,365)=7.96, p<.01$. Vastgesteld kan worden dat ook kontrole eenheden elementen van Integrerende Verpleegkunde tijdens het onderzoek lijken te hebben geïntroduceerd.

In hoofdstuk 6 en 7 bleek dat Integrerende Verpleegkunde met name een 
verschuiving betekent van taken en verantwoordelijkheden binnen de verpleegkundige organisatie. Nagaan zal worden of er naast de verschillen tussen de twee kondities, ook veranderingen in de invloedsverhoudingen binnen de verpleegkundige discipline in beide kondities hebben plaatsgevonden. In Tabel 8-1 wordt een overzicht gegeven van de signifikante verschuivingen in de machtsverhoudingen van de verpleegkundige en de verpleegkundige leiding. Op grond van de tabel kan vastgesteld worden dat naast de

Tabel 8-1. De machtspositie van de verpleegkundige leiding en de verpleegkundigen op de drie meetmomenten (mei/juni ' 84 [1e], nowember/december '84 [2e] en mei/juni "85 [3e])

\begin{tabular}{|c|c|c|c|c|c|c|}
\hline \multirow[t]{2}{*}{ Variabele } & \multicolumn{3}{|c|}{ Univariate toets } & \multicolumn{3}{|c|}{ Gemiddelden } \\
\hline & $\mathrm{F}$ & df & $p<$ & $1 e$ & 20 & $3 \mathrm{e}$ \\
\hline $\begin{array}{l}\text { Mate warin de verpleegkundige } \\
\text { leiding zelfstandig kan beslissen }\end{array}$ & 15.02 & 2,530 & .001 & .44 & .33 & 30 \\
\hline $\begin{array}{l}\text { Mate waarin verpleegkundigen } \\
\text { zelfstandig kumen beslissen }\end{array}$ & 4.94 & 2,530 & .01 & .30 & .35 & .37 \\
\hline $\begin{array}{l}\text { Mate waarin met de verpleegkundige } \\
\text { leiding wordt overlegd }\end{array}$ & 25.43 & 2,527 & .001 & .63 & .47 & .41 \\
\hline $\begin{array}{l}\text { Mate waarin met de verpleegkundigen } \\
\text { wordt overlegd }\end{array}$ & 4.98 & 2,527 & .01 & .48 & .54 & .54 \\
\hline $\begin{array}{l}\text { Invloed van de verpleegkundige } \\
\text { leiding op de zorg. }\end{array}$ & 3.91 & 2,464 & .05 & 2,93 & 2.78 & 2.76 \\
\hline $\begin{array}{l}\text { Mate waarin men afhankelijk is } \\
\text { wan de verpleegkundige leiding. }\end{array}$ & 3.75 & 2,475 & .05 & 3.57 & 3.41 & 3.30 \\
\hline
\end{tabular}

verschillen tussen de twee kondities, er in beide kondities gedurende het experiment verschuivingen hebben plaatsgevonden in de positie van de verpleegkundige leiding en de verpleegkundigen. Dit geldt --gelet op de gemiddelden-- met name voor het tijdsbestek tussen de eerste en tweede meetperiode. Het voorgaande wijst er op dat ook de kontrole verpleegeenleden elementen van Integrerende Verpleegkunde hebben geintroduceerd. Kontrole eenheden kunnen dit hebben gedaan onder invloed van het experiment ('uitstralingseffekt') of onder invloed van meer algemene ontwikkelingen. Een uitstralingseffekt zal groter zijn naarmate kontrole eenheden meer in de nabijheid van experimentele eenheden zijn gesitueerd. Vanuit deze optiek kunnen drie groepen kontrole eenheden onderscheiden worden, namelijk:

-binnen een kliniek waar experimentele eenheden zijn gelokaliseerd

-binnen het zelfde ziekenhuis, maar in een andere kliniek

-in een ander ziekenhuis

Wanneer deze drie groepen met elkaar worden vergeleken ten aanzien van de variabelen uit Tabel 8-1, dan moet gekonkludeerd worden dat er geen duidelijk uitstralingseffekt heeft plaatsgevonden. De reakties uit het andere ziekenhuis komen 
het meest overeen met de reakties van de experimentele eenheden en de reakties van eenheden uit een andere kliniek van het Academisch Ziekenhuis Groningen komen hier het minst mee overeen.

Veranderingen in de kondities om Integrerende Verpleegkunde te implementeren. In mei 1983 werd door de leidinggevenden van alle eenheden $(n=75)$ aangegeven hoe geschikt de eenheid zou zijn woor deelname aan het experiment. In november 1985, na afloop van het experiment, werden deze vragen opnieuw aan de leidinggevenden voorgelegd $(n=54)$. Het aantal leidinggevenden is ten tijde van het experiment afgenomen, omdat door het ziekenhuis management er naar werd gestreefd de funktie van waarnemend hoofdverpleegkundige (WHVE) ap te heffen. Vakatures werden niet meer opgevuld. De mening van de leidinggevenden in 1985 werd vergeleken met de mening voor aanvang van het experiment. Hen werd gevraagd (zie ook Tabel 4-1) aan te geven hoe belangrijk zij elk van de kondities vonden ('belief': score $0=$ geheel onbelangrijk; score $3=z e e r$ belangrijk). Tevens hebben zij de eigen eenheid aan de hand van deze kondities geèvalueerd ('evaluatie': score $-2=$ zeer ongunstig; score $2=$ zeer gunstig). Per konditie werd de multiplikatieve term 'belief' maal 'evaluatie' berekend. Tevens werd een somscore over de dertien multiplikatieve termen berekend (range -6 tot 6).

Het blijkt dat over het geheel genomen men in 1985 de omstandigheden voor het invoeren van Integrerende Verpleegkunde verbeterd vindt: $F(1,126)=10.45, p<.01$, het gemiddelde in 1983 bedraagt 1.03 en in 1985 1.95. Wanneer naar de afzonderlijke kondities gekeken wordt, dan blijkt dat men ten aanzien van geen van de dertien kondities de situatie verslechterd vindt. De situatie vindt men verbeterd ten aanzien van de volgende vier kondlities:

-de motivatie van verpleegkundigen: $F(1,128)=25.31, p<.001$, gemiddelden 1.30 en 4.03 .

-de motivatie van artsen: $F(1,127)=13.67, \mathrm{p}<.001$, gemiddelden -.35 en 1.42 . -de motivatie van de verpleegkundige leiding: $F(1,128)=4.99, p<.05$, gemiddelden 2.84 en 4.11 .

-de personeelsopbouw: $F(1,127)=4.48, p<.05$, gemiddelden 1.01 en 2.23 .

Het blijkt dat vooral de motivatie van verpleegkundigen om volgens het model van Integrerende Verpleegkunde te werken, naar het oordeel van de verpleegkundige leiding, is gestegen. De houding van de artsen is naar hun mening van 'enigszins negatief' naar 'enigszins positief' omgeslagen. Dat de personeelsopbouw positiever wordt beoordeeld kan mede zijn veroorzaakt door de afoouw van de inservice opleiding voor verpleegkundigen in het ziekenhuis (1981), waardoor uitsluitend gediplomeerde verpleegkundigen op de verpleegeenheden werkzaam zijn. Door deze afbouw zijn meer dagschoolopgeleiden aangesteld, die gemiddeld positiever staan tegenover verpleegkundige innovaties (zie bijwoorbeeld Aukes et al., 1987). De respondenten werd overigens ook rechtstreeks gevraagd naar de invloed van het experiment op de eigen verpleegeenheid. Van de respondenten geeft $12 \%$ aan dat er geen positieve invloed is geweest en $46 \%$ geeft aan dat er enige positieve invloed is geweest. De overige $42 \%$ heeft een redelijk grote of zeer grote positieve invloed ervaren. Gekonkludeerd mag worden dat de leidinggevenden de situatie om de nieuwe verpleegkundige werkwijze te introduceren positiever inschatten. Dit wijst er op dat het experiment een positieve invloed heeft gehad op de houding ten aanzien van Integrerende Verpleegkunde. 
Samengevat kan vastgesteld worden dat deze secundaire analyses laten zien dat er naar alle waarschijnlijkheid een zekere diffusie of kontaminatie van de experimentele en kontrole konditie heeft plaatsgevonden. Dit kan er toe hebben bijgedragen dat de gevolgen van Integrerende Verpleegkunde minder sterk naar voren zijn gekomen.

\section{Reakriviteit.}

Het materiaal in dit onderzoek is vrijwel uitsluitend verzameld met behulp van vragenlijsten. Bij 'self-report' technieken als deze, bestaan er voor de respondenten meer mogelijkheden bij hun reakties specifieke overwegingen, motieven en belangen mee te laten spelen. Men wil zich bijvoorbeeld 'van de goede kant laten zien', men hecht belang aan bepaalde uitkomsten van het onderzoek, men is gedemotiveerd omdat men niet deelneemt aan de experimentele konditie of men ervaart een zekere rivaliteit met de experimentele verpleegeenheden. De mate waarin deze faktoren het materiaal kunnen hebben beïnvloed zal per groep respondenten verschillen.

Het is bekend (zie hoofdstuk 1) dat patiënten zich tijdens het verblijf in het ziekenhuis erg afhankelijk voelen van artsen en verpleegkundigen en zich over het algemeen -mede hierdoor- zeer positief uitlaten over de wijze waarop ze worden behandeld en verzorgd. $\mathrm{Er}$ is echter geen reden om te veronderstellen dat een dergelijke 'bias' in de ene konditie zich sterker heeft gemanifesteerd dan in de andere konditie. Bovendien werd de patiënten niet gevraagd naar hun tevredenheid met de zorg, maar naar onderwerpen die minder gevoelig zullen zijn voor een dergelijke 'bias", zoals 'stress', 'waargenomen invloed' en 'de door de patiënt genomen initiatieven'. Overigens zijn de patiënten niet op de hoogte geweest van de aard van het experiment en het doel van het onderzoek.

Voor de artsen ligt de situatie mogelijk anders. Het bleken met name de medische specialisten in opleiding (zaalartsen) die problemen hebben ervaren als gevolg van de introduktie van het verpleegkundig model. Deze zaalartsen hebben over het algemeen lange werkdagen en ervaren een grote werklast. Tijdens de interviews met hen (zie hoofdstuk 6), bleek dat zij van mening zijn dat door Integrerende Verpleegkunde, verpleegkundigen betere informatie over individuele patiënten kunnen verstrekken, maar dat deze informatie vaak niet of niet snel genoeg beschikbaar is, omdat de verpleegkundige op dat moment niet werkt of zich elders buiten de eenheid bevindt. Artsen waren over het algemeen geen grote voorstander van de nieuwe werkmethode. Zij beoordelen de verpleegkundigen van experimentele eenheden minder positief, maar hun ervaringen ten aanzien van de meeste andere aspekten --zoals de invloedspositie van verpleegkundigen-- vertoont grote overeenkomst met de ervaringen van de verpleegkundigen. Ook is gebleken dat naar het oordeel van de verpleegkundige leiding van het gehele ziekenhuis, de houding van artsen ten opzichte van het verpleegmodel in de loop van het experiment positiever is geworden. Gelet op het voorgaande, is het mogelijk dat artsen, vooral in de beginfase, zich extra negatief hebben uitgelaten over de door hen ervaren veranderingen.

In de reakties van de verpleegkundigen zullen specifieke motieven waarschijnlijk het sterkst een rol gespeeld hebben. Zo werden die verpleegeenheden geselekteerd, die gemotiveerd en bereid waren om aan het experiment deel te nemen. Bij de selektie van experimentele eenheden bleek slechts een beperkt deel van de leidinggevenden bereid in het experiment te participeren. Veel leidinggevenden waren zich er wan 
bewust dat Integrerende Verpleegkunde woor hen zou betekenen dat zij niet of nauwelijks nog direkt kontakt zouden hebben met patiënten. Leidinggevenden ontlenen hun positie vaak meer aan ervaring en deskundigheid in de direkte patiëntenzorg, dan aan hun organisatorische of voorwaardescheppende kapaciteiten. Een aantal leidinggevenden zullen een mogelijke introduktie van het nieuwe model als bedreigend ervaren hebben. Andere leidinggevenden hadden graag aan het experiment willen deelnemen maar vielen af, omdat bijvoorbeeld het koördinerend hoofd niet bereid was deel te nemen. Over het geheel genomen zal de houding van de verpleegkundige leiding en de verpleegkundigen van de kontrole eenheden beïnvloed zijn door gevoelens van rivaliteit, 'het goed uit de bus willen komen' of de mogelijkheid dat belang gehecht wordt aan specifieke uitkomsten van het onderzoek. Deze motieven zullen 'biases' in verschillende richting hebben veroorzaakt. In die zin is er geen reden te veronderstellen dat er zich een sterke systematische bias heeft voorgedaan. Naast de hierboven beschreven 'gemotiveerde biases', kunnen zich ook nog bèta- of gamma-veranderingen hebben voorgedaan (zie 4.2). Dit houdt in dat verpleegkundigen van experimentele eenheden een aantal begrippen anders is gaan waarderen of dat voor hen de betekenis van begrippen is veranderd. In zekere zin beoogt Integrerende Verpleegkunde zelfs gamma-veranderingen, doordat onder andere veranderingen in de beroepsvisie van verpleegkundigen worden nagestreefd (Grypdonck, 1988; zie 1.2). Bovendien kan een zekere 'gewenning' optreden ten aanzien van een situatie waarin bijvoorbeeld feitelijk de handelingsruimte, de taakbijdrage en de machtspositie is veranderd. Vooral bij de in deze studie gebruikte antwoordkategorieën, zoals 'noont/vaak' of 'geheel niet/erg veel', kan herijking plaatsvinden (bèta-veranderingen; zie ook Van de Vliert et al., 1986).

Gekonkludeerd mag worden dat een ongelijke systematische bias in de twee kondities niet waarschijnlijk is, voor zover het de reakties van de patiënten betreft. Ten aanzien van de reakties van verpleegkundigen kan dit in zekere mate wel het geval geweest zijn. Het is niet aannemelijk dat dit een belangrijke oorzaak is van de gevonden verschillen tussen de twee kondities. Het is echter aan te bevelen in vervolgonderzoek ook andere methoden van data-verzameling --zoals observaties-- te gebruiken.

\section{Selektie.}

De eerste meting heeft plaatsgevonden op een moment dat de introduktie van het model al voor een deel had plaatsgevonden. Om deze reden kan niet worden vastgesteld in welke mate de twee kondities vór de eerste kennismaking met het model, onderling al op relevante kenmerken verschilden. Verschillen op deze kenmerken zouden de verschillen die gevonden werden tussen de twee kondities kunnen verklaren ('selection bias'). De verschillen tussen de kondities zouden daarmee niet zonder meer aan de introduktie van het verpleegkundige model toegeschreven kunnen worden. Uit de interviews met de artsen en uit de reakties van de verpleegkundigen en de verpleegkundige leiding in een groot aantal schriftelijke rapportages in het kader van het experiment, valt echter op te maken dat zij de veranderingen in de verpleegkundige organisatie en in de patiëntenzorg zoals in hoofdstuk 5 , 6 en 7 beschreven, over het algemeen zeer expliciet in verband brengen met de introduktie van het model (zie bijvoorbeeld, Emans \& den Boer, 1988). 


\section{Samengevat.}

Het blijkt dat de studie een aantal methodologische problemen kent. De volgende problemen kunnen zich in meer of mindere mate hebben voorgedaan:

-de kontrole eenheden hebben tijdens het experiment ook elementen van

Integrerende Verpleegkunde geïntroduceerd (kontaminatie).

-biases" in de reakties van met name de verpleegkundigen (reaktiviteit).

-verschillen tussen de twee kondities bestonden al voor de introduktie van het nieuwe model (selektie).

Hoewel niet precies vastgesteld kan worden in welke mate deze problemen de resultaten hebben beïnvloed, is het niet waarschijnlijk dat zij de gevonden verschillen volledig kunnen verklaren.

\subsection{Theoretische en praktische implikaties.}

\section{De patiënt.}

In de inleidende hoofdstukken 2 en 3 werden mede op grond van theoretische inzichten en elders verricht onderzoek, een aantal verwachtingen geformuleerd omtrent de gevolgen van Integrerende Verpleegkunde. De introduktie van het model houdt in, dat op een verpleegeenheid de werkzaamheden anders worden verdeeld, waardoor individuele verpleegkundigen verantwoordelijk worden voor de totale verpleegkundige zorg van een patiënt (patiënttoewijzing), waarbij de verpleegkundige zijn of haar werkzaamheden planmatig uitvoert en hier de patiënt expliciet bij betrekt. Het is gebleken dat men er redelijk in is geslaagd patiënttoewijzing in te voeren, maar dat dit nog maar in beperkte mate gelät voor de nieuwe methodiek.

Verwacht werd dat patiënten, doordat zij met minder verschillende verpleegkundigen in kontakt komen en bij de verzorging worden betrokken, meer invloed zouden gaan ervaren op de zorg. Ze zouden zich hierdoor meer verantwoordelijk gaan voelen voor de behandeling en de verzorging en zich meer gaan inzetten voor een optimaal resultaat. Er bleken verschillen tussen de reakties van de patiënten uit de twee kondities in de voorspelde richting te bestaan, maar deze verschillen bleken niet erg groot te zijn. Hiervoor werden al enkele mogelijke oorzaken genoemd. Op de experimentele eenheden is het model (nog) niet geheel ingevoerd, met name zouden patiënten meer expliciet bij de planning en uitvoering van de zorg betrokken kunnen worden (zie 5.5). Daarnaast hebben kontrole eenheden ook elementen van Integrerende Verpleegkunde geüntroduceerd (zie 8.2). Tevens kan, gezien de gemiddeld hoge leeftijd van patiënten en het gemiddeld grote aantal dagen dat zij in het verleden opgenomen zijn geweest, verondersteld worden dat de verwachtingen van patiënten over de eigen rol in het ziekenhuis, tamelijk sterk verankerd zullen zijn (zie 5.5). Voorts werd naar voren gebracht dat patienten zich mogelijk primair richten op de behandeling door de arts en hun houding en hun gedrag vooral hierdoor laten beïnvloeden (zie 5.5 ).

Hulpeioosheid. Naast bovengenoemde oorzaken voor de marginale effekten bij patiënten, kan het in het tweede hoofdstuk geschetste theoretische model bekritiseerd 
worden. Daar werd gesteld dat de organisatie van de verzorging en de behandeling in ziekenhuizen de patiénten onnodig afhankelijk maakt. Het verblijf van patiënten in een ziekenhuis werd beschreven als een periode waarin naast de afhankelijkheid vanwege de lichamelijke aandoening, de patiëntenzorg zodanig is georganiseerd, dat de afhankelijkheid van de patiênt nog verder wordt vergroot. Dit zou dan uiteindelijk resulteren in wolledig afhankelijke, depressieve en hulpeloze patiënten. We vinden in deze studie aanwijzigingen, dat depersonalisatie en afhankelijkheid als gevolg van hospitalisatie, met de daarbij behorende onwenselijke gevolgen voor patiënten, niet lijken op te treden. Zo blijkt dat in beide kondities de door patiënten ervaren stress tijcens de opname aanzienlijk afneemt, de kennis over ziekte en behandeling redelijk sterk toeneemt en patiënten wat mirnder defensieve strategieën gaan gebruiken. Verder wordt -ook in beide kondities- een positieve samenhang gevonden tussen de opnameduur en het gebruik van probleemoplossende strategieën door patiënten, de kennis van patiênten over ziekte en behandeling en het ontplooien van initiatieven. De meeste patiënten worden in een ziekenhuis opgenomen voor een ingrijpende behandeling. Het ligt min of meer voor de hand dat, wanneer zij uit het ziekenhuis ontslagen worden, de behandeling achter de rug is en patiënten verwachten dat de behandeling verbetering zal geven, cle stress is afgenomen. Tijdens het verblijf zal een patiënt informatie ontvangen over ziekte en behandeling. Het is dan ook voor de hand liggend dlat gedurende het verblijf de kennis van een patiënt over ziekte en behandeling toe- en niet afneemt. De resultaten van deze studie roepen dan ook niet zo zeer een beeld op van 'ziekmakende ziekenhuizen'.

Grenzen van invloed. Men kan zich afvragen in hoeverre het vergroten van de invloed van een patiënt op zijn verzorging wenselijk is. In het tweede hoofdstuk werd de indruk gewekt dat 'hoe meer invloed de patiënt heeft, hoe beter het is'. Wanneer een patiënt verwacht dat hij of zij het verblijf in het ziekenhuis of de snelheid van het herstel kan beïnvloeden, zal deze meer probleemoplossende initiatieven ontplooien, waardoor de kans groter wordt dat het probleem wordt opgelost dan wanneer door de patiënt geheel geen akties ondernomen zouden worden. Wanneer echter de aktuele beïnvloedingsmogelijkheden sterk worden overschat, zal de kans op succes aanzienlijk verminderen. Het ervaren van invloed, wanneer deze feitelijk niet of nauwelijks bestaat, kan bovendien tot gevolg hebben dat onverantwoorde risico's genomen worden (zie bijvoorbeeld Folkman, 1984). Een patiënt die na een operatieve ingreep bijwoorbeeld te snel een grote krachtsinspanning wil leveren kan inwendige bloedingen krijgen. Daarnaast is gebleken dat indien feitelijke beïnvloeding wel mogelijk is, rekening gehouden moet worden met de kosten om deze invloed uit te oefenen (Solomon, Holmes \& McCaul, 1980; Fleming, Baum \& Singer, 1984). Een patiënt zal idealiter naar vermogen verantwoordelijkheid dragen voor zijn eigen gezondheid en naar vermogen zich zo weinig mogelijk afhankelijk moeten opstellen ten opzichte van gezondheidszorginstellingen. In termen van de zelfzorgtheorie van Orem (zie Brouns, 1988) schiet het zelfzorgvermogen niet alleen tekort wanneer een patiënt niet in staat is bepaald zelfzorggedrag te vertonen, maar ook indien met dit gedrag niet het beoogde doel wordt bereikt. Het is in die zin wenselijk dat verpleegkundigen bij het vaststellen van de doelen van de verpleegkundige zorg, in overleg met de patiënt, zich een reëel beeld vormen van de mogelijkheden van een patiënt om voor zijn of haar eigen 
gezondheid te zorgen (zie Diemert Moch, 1988).

Samengevat kan vastgesteld worden dat de veranderingen woor de patiënt als gevolg van de inwoering van Integrerende Verpleegkunde beperkt zijn, maar voorzover er verschillen zijn tussen de twee kondities, deze in de voorspelde en gewenste richting zijn. Als mogelijke oorzaken voor de beperkte gevolgen konden aangewezen worden: -het model is nog niet volledig ingevoerd

-ook kontrole eenheden hebben onderdelen van Integrerende Verpleegkunde ingevoerd

Verwacht mag worden dat indien het model optimaal is ingevoerd er een verdere kwaliteitsverbetering van de zorg zal optreden. De mate waarin Integrerende Verpleegkunde de kwaliteit van de zorg zal kunnen verbeteren is echter begrensd. Gezien de gemiddeld hoge leeftijd van patiënten zullen opvattingen over gezondheid en gezondheidsgedrag vaak sterk verankerd zijn. Een kort verblijf in een ziekenhuis zal het gedrag van een patiënt maar in beperkte mate kunnen beïnvloeden. Daarnaast is (een verandering in) de verpleegkundige zorg maar één van de faktoren, naast bijvoorbeeld de behandeling door de medische specialisten en paramedici, die het gedrag en de houding van patiënten in een ziekenhuis zal beïnvloeden.

\section{De verpleegkundige organisatie.}

Macht en machtsverhoudingen.In hoofdstuk 3 werden hypothesen geformuleerd betreffende de effekten van Integrerende Verpleegkunde voor de verpleegkundigen. Verwacht werd dat met name de machtspositie van de verpleegkundigen in de direkte patiëntenzorg zou worden versterkt. Het bleek dat deze machtspositie volgens alle groepen respondenten op experimentele eenheden grater is dan op kontrole eenheden. In zoverre machtsverschuivingen hebben plaatsgevonden, betreffen deze vooral de invloed van verpleegkundigen en de verpleegkundige leiding op de directe patiëntenzorg. De specifieke deskundigheid van artsen, zeker specialisten en artsen die al enkele jaren hun opleiding volgen, wordt niet door veranderingen in de verpleegkundige organisatie aangetast. In die zin is het verklaarbaar dat de grotere participatie van verpleegkundigen in beslissingen en planning van de directe patiëntenzorg niet ten koste gaat van de positie van artsen (vergelijk Mulder \& Wilke, 1970). Samengevat treden de grootste verschuivingen op in de machtsverhoudingen binnen de verpleegkundige discipline. De werantwoordelijkheid voor de direkte patiëntenzorg is binnen deze discipline gedecentraliseerd.

Naast de hiervoor beschreven verschillen tussen de twee kondities, blijkt dat de verschillende groepen respondenten in beide kondities de machtsverhoudingen verschillend waarnemen. Zo blijkt bijvoorbeeld dat de verpleegkundige leiding de invloed van de arts, de koördinerend hoofdverpleegkundige, de hoogleraar en de registratie-assistent op het beleid van de verpleegeenheid --het invloedsgebied van bij uitstek de verpleegkundige leiding- klein windt, wanneer dit vergeleken wordt met de mening van artsen en verpleegkundigen over de invloed van deze personen op de algehele gang van zaken. Deze bevindingen passen binnen de machtsafstand reduktie theorie van Mulder (1972). Het blijkt namelijk dat de verpleegkundige leiding, de invloed van (groepen) personen die weinig invloed hebben op de besturing van de verpleegeenheid, relatief laag inschat. De (zaal)arts heeft de meeste invloed op de 
direkte patiëntenzorg. Ook hier blijkt dat de arts de invloed wan de groeperingen die hier minder invloed op hebben --de verpleegkundigen en de verpleegkundige leiding- lager inschat dan de verpleegkundigen en de verpleegkundige leiding.

Macht beïnvloedende faktoren. In hoofdstuk 3 werd aangegeven dat de machtspositie van een specifieke groepering binnen een organisatie wordt bepaald door verschillende faktoren. Genoemd werden onder andere de statuskarakteristieken van personen, de handelingsruimte die men van andere leden in de organisatie krijgt, de taakbijdrage die men levert en de strategie die men hanteert bij het beünvloeden van anderen in het bedrijf. Uit de literatuur kwam naar voren dat het over het algemeen niet eenvoudig is binnen een bestaande organisatie de machtspositie van een groepering blijvend te versterken. Binnen het projekt is getracht door overleg met bestuurders en medici wooraf, voor de duur van het experiment extra handelingsruimte te creëren voor verpleegkundigen. Dit in de verwachting dat, indien verpleegkundigen deze ruimte op de juiste wijze zouden weten te gebruiken, door onder andere een grotere taakbijdrage die door anderen wordt gewaardeerd, de invioedspositie van verpleegkundigen blijvend zou kunnen worden versterkt, zodat de extra handelingsruimte behouden zou kunnen blijven. Wanneer de resultaten bekeken worden vanuit de 'Expectation States Theory', dan kan vastgesteld worden dat door de respondenten een sterkere machtspositie met name geassocieerd wordt met het gebruik van probleemoplossende, op koöperatie gerichte beïnvloedingsstrategieën, een algehele positieve evaluatie, bekwaamheid en een grote verbondenheid met de door te voeren veranderingen. Een aantal kondities die van belang zijn voor het versterken van de machtspositie blijken op experimentele eenheden gunstiger dan op kontrole eenheden. Zo blijken verpleegkundigen een grotere takabijdrage te leveren en zich meer gebonden te achten aan het welslagen van de verpleegkundige vernieuwingen. Het is voor de konsolidatie van macht uiteindelijk van groot belang dat anderen in de organisatie --en vooral meer machtigen zoals de verpleegkundige leiding en artsen-- de veranderingen positief waarderen. Gekonstateerd moet echter worden dat verpleegkundigen van experimentele eenheden minder positief door artsen worden beoordeeld dan verpleegkundigen van kontrole eenheden. Het bleek dat artsen op experimentele eenheden meer met afzonderlijke verpleegkundigen. moeten overleggen en dat dit kan verklaren waarom zij verpleegkundigen minder positief beoordelen. Mede op grond van deze bevinding werd bij een zevental artsen van experimentele eenheden een interview afgenomen. Door hen werd positief ervaren dat verpleegkundigen meer betrokkenheid bij de patiëntenzorg toonden en aan de artsen betere informatie over patiënten konden verstrekken. Als een groot probleem werd echter door hen ervaren -zoals al eerder naar voren gebracht-- dat het hen veel meer tijd kost om de juiste verpleegkundige, verantwoordelijk voor een specifieke patiënt, te pakken te krijgen. De machtspositie van artsen voor zover het hun 'deskundigheid' betreft, wordt niet door Integrerende Verpleegkunde bedreigd. Veel tijd steken in het opsporen van (minder machtige) telkens weer andere verpleegkundigen, kan door hen echter wel als een verkleining van de machtsafstand ervaren worden. Vanuit dit perspektief is het begrijpelijk dat zij de verpleegkundigen van experimentele eenheden minder positief beoordelen (vergelijk Mulder, 1972). Artsen geven de voorkeur aan eén koördinerend persoon op de verpleegeenheid waarmee zij kunnen overleggen. Verpleegkundigen doen er dan ook goed aan, wil men de verkregen ruimte 
behouden, hierover in owerleg te treden met de artsen en er zorg voor te dragen dat dit probleem zoveel mogelijk wordt opgelost.

\section{Konklusies en aambevelingen}

Vastgesteld mag worden dat men er voor een deel in is geslaagd het model Integrerende Verpleegkunde te introduceren. Het systeem yan patiènttoewijzing is meer operationeel dan het 'systematisch verpleegkundig handelen'. Met mame de participatie van patiënten bij het vaststellen van de doelen, de inhoud en de evaluatie van de zorg vraagt verdere aandacht. Een aangrijpingspunt hiervoor vormt de recente ontwikkeling binnen de verpleegkundige professie van verpleegkundige protokollen. In deze protokollen, vaak standaardverpleegplannen genoemd, worden per kategorie patiënten de meest voorkomende verpleegkundige problemen beschreven. Deze plannen zijn gestruktureerd analoog aan het systematisch verpleegkundig handelen. Verwacht mag worden dat indien verpleegkundigen bij het plamnen van hun werkzaamheden gebruik maken van de protokollen, dit het 'systematisch verpleegkundig handelen' zal bevorderen. Om de participatie van patiënten te bevorderen is het mogelijk wenselijk dat patiënten inzage hebben in de verpleegplannen. Ook een gerichte vaardigheidstraining voor verpleegkundigen zou de participatie kunnen bevorderen,

De introduktie van Integrerende Verpleegkunde heeft met name verandering teweeg gebracht binnen de verpleegkundige beroepsgroep. De verpleegkundige leiding heeft de taken die de direkte patientenzorg betreffen gedelegeerd aan individuele verpleegkundigen. Het lijkt er op dat op een aantal terreinen de verpleegkundige leiding de grootste veranderingen ervaart (zie bijvoorbeeld Figuur 6-3). Van de verpleegkundige leiding wordt niet alleen verwacht dat zij individuele verpleegkundigen ondersteunt, het verpleegkundig afdelingsbeleid ontwikkeit en vaststelt, maar ook de kwaliteit van de zorg bewaakt en leiding geeft aan aen veranderingsproces --de invoering van Integrerende Verpleegkande-- dat grote gevolgen heeft voor de positie van de leiding zelf. Het is dan ook wenselijk dat bij introduktie van het model de leiding intensief door een 'veranderingsdeskundige' wordt gesteund (zie Emans \& den Boer, 1988). Daarnaast bieden de eerdergenoemde protokollen de verpleegkundige leiding de mogelijkheid om (een deel van) het verpleegkundig beleid vast te leggen en de nitvoering van de zorg door individuele verpleegkundigen te bewaken.

Verwacht werd dat binnen de experimentele konditie de "senioriteit" van verpleeg* kundigen de toename van invloed zou versterken. Het bleek echter dat senior verpleegkundigen niet meer invloed hebben dan jongere en minder ervaren kollega"s. De afgelopen 5 à 10 jaar is binnen het verpleegkundig onderwijs veel meer de nadruk komen te liggen op het "systematisch verpleegkundig handelen". Het kunnen hanteren van de methode zal door de introduktie van Integrerende Verpleegkunde meer aanziem hebben gekregen. Dit kan verklaren waarom senior werpleegkundigen niet meer inwloed ervaren. Hieruit kan tevens worden opgemaakt dat bijscholing van de oudere verpleegkundige op het terrein van de verpleegkundige methodieken wellicht wensellik is.

De positie van de arts lijkt door integrerende Verpleegkunde niet te worden angetast. Een aantal aspekten in de verpleegkundige zorg vinden artsen verbeterd, zoals de kwaliteit van de informatie van verpleegkundigen over individuele patienten en de betrokkenhejd van verpleegkundigen bij de zorg. Daar staat tegenover dat het 
een arts meer tijd kost om in overleg te treden met een verpleegkundige die voor een specifieke patiënt zorgt. Dit lijkt meer een praktisch probleem dan een principieel obstakel. Aangezien het wenselijk is dat artsen de nieuwe verpleegkundige werkwijze steunen of in ieder geval gedogen, vraagt de bereikbaarheid van verpleegkundigen aandacht. Inmiddels kunnen op verschillende eenheden verpleegkundigen door middel van een teletracer ("pieper") opgeroepen worden. Bij het bed van een patiënt wordt het betreffende oproepnummer vermeld.

We kunnen konkluderen dat het experiment een aantal beoogde effekten heeft opgeleverd. Bij de (verdere) introduktie van het model vragen de volgende onderwerpen specifieke aandacht:

-het ontwerpen van verpleegkundige protokollen als instrument voor de kwaliteitsbewaking door de leiding en ter stimulering van het systematisch verpleegkundig handelen van verpleegkundigen.

-het trainen van verpleegkundigen gericht op vaardigheden om patiênten bij de zorg te betrekken

-ondersteuning van de verpleegkundige leiding in het veranderingsproces

-bijscholing van (oudere) verpleegkundigen die over onvoldoende kennis beschikken wat verpleegkundige werkmethodieken betreft -de bereikbaarheid van verpleegkundigen woor artsen

Tot besluit. De introduktie van Integrerende Verpleegkunde heeft met name veranderingen in de verpleegkundige organisatie veroorzaakt. De gevolgen voor andere medewerkers van het ziekenhuis en voor de patiënten zijn (nog) beperkt gebleven. Het experiment heeft ook invloed gehad op de houding van verpleegkundigen buiten de experimentele eenheden en buiten het ziekenhuis. Inmiddels heeft het ziekenhuis gekozen voor Integrerende Verpleegkunde als onderdeel van het verpleegkundig beleid. De taakverruming en de decentralisatie van verantwoordelijkheden binnen de verpleegkundige discipline heeft de funktie van de verpleegkundige leiding verder beïnvloed. De funktie van waarnemend hoofd verpleegkundige is afgeschaft en de verpleegkundige leiding geeft leiding aan grotere organisatorische eenheden. Deze afplatting van de verpleegkundige organisatie heeft tot gevolg dat de traditionele weg om binnen het beroep carrière te maken --een leidinggevende funktie-- zijn beperkt. Om als ziekenhuis aantrekkelijk te blijven voor verpleegkundigen wordt gezocht naar meer horizontale funktie differentiatie, bijvoorbeeld verpleegkundigen die na een wetenschappelijke opleiding naast hun verpleegkundige werkzaamheden, vergelijkbaar met de medische specialisten, klinisch onderzoek verrichten. 


\section{SAMENVATTING}

Dit proefschrift handelt over de gevolgen van de introduktie van het model Integrerende Verpleegkunde op enkele verpleegeenheden van een ziekenhuis. Het gaat daarbij om de gevolgen voor patiënten, de verpleegkundigen, de verpleegkundige leiding en enkele andere disciplines en groeperingen binnen de ziekenhuisorganisatie. Het model werd in de periode 1983 tot 1985 op vier verpleegeenheden van het Academisch Ziekenhuis te Groningen gë̈ntroduceerd. In deze periode werden op drie momenten vragen voorgelegd aan patiënten, verpleegkundigen, de verpleegkundige leiding en artsen. Deze vragen werden op ongeveer dezelfde tijdstippen ter vergelijking ook voorgelegd aan patiënten, verpleegkundigen, leidinggevenden en artsen van een zevental verpleegeenheden waar het model niet werd ingevoerd. Het gaat hier om vijf verpleegeenheden uit hetzelfde ziekenhuis en twee verpleegeenheden van een ander Academisch Ziekenhuis.

In hoofdstuk 1 wordt in het kort een schets gegeven van de voorgeschiedenis. Daarbij wordt ingegaan op enkele veranderingen die de laatste decennia in de verpleegkundige organisatie binnen ziekenhuizen hebben plaatsgevonden en die er toe hebben bijgedragen dat er binnen de verpleegkundige discipline een sterke behoefte is ontstaan aan professionalisering van het beroep. Integrerende Verpleegkunde kan als een exponent van deze professionalisering worden beschouwd.

Integrerende Verpleegkunde beoogt de kwaliteit van de zorg voor patiënten te verbeteren, de beroepsontwikkeling te stimuleren en de ontwikkelingsmogelijkheden van individuele verpleegkundigen te bevorderen. Binnen de traditionele wijze van verplegen --ook funktionele verpleging genoemd-- worden aan verpleegkundigen taken toegewezen. Deze taken voeren zij uit bij een groot aantal verschillende patiënten binnen de verpleegeenheid. De taken zijn gericht op verschillende zorgvragen van een patiënt. Deze werkorganisatie heeft enerzijds tot gevolg dat er vaak onvoldoende aandacht is voor de samenhang van de diverse deelproblemen van een patiënt. Integrerende Verpleegkunde legt de nadruk op een integrale benadering van de problemen van een patiënt en daarmee op een integratie van de daaruit voortkomende verpleegkundige werkzaamheden. Anderzijds impliceert de traditionele werkverdeling een ver doorgevoerde taak- en funktie-differentiatie, hetgeen tot gevolg kan hebben dat verpleegkundigen de betekenis van hun eigen taakbijdrage in het total van de zorg aan een patiënt niet meer herkennen en hierdoor gedemotiveerd raken. Integrerende Verpleegkunde streeft naar horizontale en vertikale taakverruiming, waarbij verpleegkundigen de verantwoordelijkheid krijgen over de totale verpleegkundige zorg van enkele patiënten.

De twee belangrijkste instrumenten van Integrerende Verpleegkunde zijn: -patiëntoewijzing. Dit wil zeggen dat een individuele verpleegkundige niet voor een groot aantal patiënten een beperkt aantal taken uitvoert, maar de verantwoordelijkheid krijgt voor de totale zorg van enkele patiënten.

-het systematisch verpleegkundig handelen, wat impliceert dat een verpleegkundige op een systematische wijze, in overleg met de patiënt, de zorgvragen vaststelt, de doelstellingen formuleert, de werkzaamheden plant, de resultaten van de akties vaststelt 
en vervolgens zonodig het plan bijstelt.

In het eerste hoofdstuk worden voorts enkele studies besproken waarin het model Integrerende Verpleegkunde of vergelijkbare manieren van werken zijn onderzocht. De meeste studies laten zien --meestal in algemene termen zoals "tevredenheid"-- dat de introduktie van deze modellen gunstige gevolgen heeft voor patiënten en verpleegkundigen. Deze resultaten bieden echter weinig aangrijpingspunten voor het formuleren wan specifieke hypothesen. In het eerste hoofdstuk worden daarom alleen enkele globale vraagstellingen geformuleerd. Verwacht wordt dat patiënten door Integrerende Verpleegkunde meer invloed krijgen op hun verzorging en dat door de invoering van het model de positie wan verpleegkundigen in het ziekenhuis wordt versterkt. Tevens wordt de verwachting geformuleerd dat de taakwerruiming bij de minder ervaren of minder geschoolde verpleegkundigen onzekerheid zal kunnen veroorzaken.

In het tweede hoofdstuk worden de te verwachten gevolgen van Integrerende Verpleegkunde woor patiënten uitgewerkt. Hierbij wordt gebruik gemaakt van inzichten uit de sociale leertheorie en meer specifiek uit de aangeleerde hulpeloosheidstheorie. Aan de hand van op deze theorieën gebaseerde empirie worden eerst de gevolgen van hospitalisatie in een situatie zonder Integrerende Verpleegkunde beschreven. In deze situatie wordt van een patiënt geen aktieve houding verwacht en wordt hij of zij niet expliciet bij het oplossen van zijn of haar gezondheidsproblemen betrokken. Bovendien hebben patiënten kontakt met veel verschillende hulpverleners die allen een deeltaak uitvoeren. Hierdoor ervaren patiênten dat zij weinig invloed hebben op de kommunikatie met hulpverleners en de inhoud wan de zorg. $\mathrm{Zij}$ kunnen zich hierdoor machteloos en afhankelijk gaan voelen van artsen en verpleegkundigen en geen verantwoordelijkheid meer ervaren voor de uitkomsten van hun verblijf in het ziekenhuis. Volgens de aangeleerde hulpeloosheidstheorie leidt dit tot depersonalisatie en depressiviteit.

Voorspeld wordt dat door Integrerende Verpleegkunde patiënten meer invloed zullen gaan ervaren op de eigen verzorging en hierdoor ook meer verantwoordelijkheid gaan voelen voor de resultaten van de zorg en het lichamelijk herstel. Verwacht wordt dat een toename van de waargenomen invloed ook tot gevolg heeft dat patiënten meer initiatief gaan tonen tijdens interakties met hulpwerleners, beter geïnformeerd raken over ziekte en behandeling en meer zelfzorgaktiviteiten gaan vertonen. Dit laatste in termen van bijvoorbeeld 'zich zelf wassen' en 'zelf de temperatuur opnemen'. Omdat verpleegkundigen in hun kontakt met patiënten hun werkzaamheden volgens de methode van 'het systematisch verpleegkundig handelen' plannen en uitvoeren, wordt verwacht dat (ook) patiênten een meer probleemoplossende benadering zullen gaan hanteren ten aanzien van hun eigen gezondheidsproblemen. Verder wordt verwacht dat naarmate een patiënt langer in een ziekenhuis is opgenomen, de hiervoorgenoemde gevolgen sterker zullen optreden. Tenslotte wordt in dit hoofdstuk onderscheid gemaakt tussen patiënten die bij opname verwachten dat zij veel invloed op de verzorging zullen hebben en patiënten die verwachten dat zij hier weinig of geen invloed op zullen hebben. Verwacht wordt dat deze laatste groep zich -ongeacht de verpleegkundige werkwijze-- zal konformeren. Patiënten die zelf verwachten invloed uit te kunnen oefenen zullen in een situatie zonder Integrerende Verpleegkunde teleurgesteld en gedeprimeerd raken, terwijl dit in een situatie met dit model niet zal gebeuren.

In het derde hoofdstuk worden hypothesen geformuleerd over de gevolgen van 
Integrerende Verpleegkunde voor verpleegkundigen en enkele ander groepen medewerkers van het ziekenhuis. Gebruik wordt gemaakt van de 'Expectation States Theory, die inzicht geeft in de wijze waarop binnen groepen machtsverhoudingen ontstaan en de machtstheorie, die de nadruk legt op de mogelijkheden van een persoon of groep personen om de eigen machtspositie te versterken. Verwacht wordt dat door de taakverruiming binnen Integrerende Verpleegkunde, de verpleegkundige een grotere taakbijdrage zal leveren aan de patiëntenzorg. De taakbijdrage wordt in de genoende theorieën gezien als een belangrijke determinant van de machtspositie. Versterking van de machtspositie kan onder andere blijken uit een grotere invloed op beslissingen die worden genomen. Ingegaan wordt op enkele kondities die het versterken van de machtspositie kumen bevorderen of belemmeren. Zo wordt verwacht dat het van groot belang is dat anderen in de organisatie de taakbijdrage positief beoordelen en verpleegkundigen zich in de samenwerking koöperatief maar wel zelfverzelkerd opstellen. Daarnaast wordt verwacht dat het voor verpleegkundigen met een hogere senioriteit en meer bekwaamheid gemakkelijker zal zijn, om meer invloed te verwerven. Ook wordt verwacht dat naarmate verpleegkundigen zich meer gebonden achten aan het succesvol doorvoeren van verpleegkundige innovaties, zij meer gemotiveerd zullen zijn om meer invloed te verkrijgen en te behouden.

Uit onderzoek naar de gevolgen van het bevorderen van de deelname wan organisatieleden aan de vorming van het beleid en de besluitvorming in bedrijven, is naar voren gekomen dat de versterking van de machtspositie van de éen, niet ten koste hoeft te gaan van de positie van een ander. Anderen zullen minder weerstand bieden aan de toename van de invloed van verpleegkundigen, wanneer de eigen invloedspositie niet wordt bedreigd. Het is daarom van belang na te gaan wat de gevolgen zijn van de introduktie van Integrerende Verpleegkunde voor de positie van andere groeperingen in de organisatie.

In het laatste deel van het derde hoofdstuk wordt aandacht besteed aan de problemen die zich bij individuele verpleegkundigen kunnen voordoen als gevolg van de taakverruiming en de toename van de verantwoordelijkheid. Verwacht wordt dat met name verpleegkundigen met minder ervaring en minder scholing onzekerheid kunnen ervaren ten aanzien van de nieuwe taakgebieden, zoals de koördinatie van zorg en de samenwerking met artsen. Met behulp van de Sociale Vergelijkingstheorie wordt ingegaan op de betekenis van het kontakt met kollega's bij het verminderen van onzekerheid. Verwacht wordt dat bij het ervaren van onzekerheid de behoefte aan overleg hierover met kollega's zal toenemen. Deze toename is sterker onder bepaalde kondities. Deze behoefte zal bijwoorbeeld sterker zijn wanneer een verpleegkundige verwacht dat kollega's vergelijkbare onzekerheden ervaren, zelf overleg als instrumenteel ziet voor het reduceren van onzekerheid en men op de verpleegeenheid positief staat tegenover interkollegiaal overleg. Verder wordt verwacht dat verpleegkundigen die er een positief zelfbeeld op na houden, het als minder bedreigend zullen ervaren onzekerheden over het eigen funktioneren naar voren te brengen.

Hoofdstuk 4 gaat over de methode van onderzoek. In het eerste deel wordt ingegaan op de wijze waarop de experimentele eenheden en de kontrole eenheden -waarmee de ontwikkelingen op de experimentele eenheden worden vergeleken- zijn geselekteerd. Vastgesteld wordt dat geen random selektie van eenheden heeft plaatsgevonden en ook geen random toewijzing van eenheden aan de twee kondities. Verondersteld wordt dat 
selektie wel van invloed zal kunnen zijn op de reakties van verpleegkundigen, maar niet of minder op de reakties van patiënten en artsen.

De geggevens werden verzameld in mei/juni 1984, november/december 1984 en mei/juni 1985 met behulp van vragenlijsten. De eerste meting vond door diverse praktische omstandigheden, 6 maanden nadat het projekt formeel was gestart plaats. De laatste meting vond enkele maanden voor de formele afronding van het projekt plaats. Er wordt in deze studie -hoewel dat wel de intentie is geweest-- dan ook niet gesproken vari een voor-, tussen- en nameting. Tevens wordt ingegaan op enkele andere mogelijk relevante methodologische problemen. Het gaat daarbij om de mogelijkheid dat diffusie van de kondities is opgetreden, doordat bijvoorbeeld verpleegkundigen uit de twee kondities erwaringen hebben uitgewisseld en ook kontrole eenheden elementen van Integrerende Verpleegkunde hebben geïntroduceerd. Ook het gegeven dat de respondenten (en met name de verpleegkundigen) zich veelal bewust zijn geweest van de onderzoekssituatie kan hun reakties hebben beïnvloed.

In het laatste deel van het vierde hoofdstuk wordt ingegaan op de gehanteerde procedure. Gedurende elk van de drie meetperiodes, werd aan alle verpleegkundigen, leidinggevenden en de medisch specialisten uit de twee kondities door middel van een vragenlijst naar hun ervaringen gevraagd. De zaalartsen --meestal medisch specialisten in opleiding-- gaven hun reaktie aan het eind van hun 3 of 6 maanden durende stage op de eenheid. De patiënten werd de dag na opname en de dag voor ontslag een vragenlijst aangeboden. Alle respondenten retourneerden de ingevulde vragenlijst in een gesloten enveloppe.

In hoofdstuk 5 worden de gevolgen voor patiënten besproken. In de eerste paragraaf wordt de inhoud van de vragenlijst besproken. Daarna wordt ingegaan op de selektie van patiënten. Gedurende de periode dat patiënten werden benaderd werden ruim 1600 patiënten opgenomen op de eenheden die bij het onderzoek waren betrokken. Ongeveer 1000 van deze patiënten hebben om verschillende redenen niet aan het onderzoek deelgenomen. Meestal was de te verwachten opnameduur te kort (49\%), was de patiënt lichamelijk of mentaal niet in staat om aan het onderzoek deel te nemen (13\%) of gaf de patiënt zelf aan niet aan het onderzoek te willen deelnemen $(8 \%)$. Nagegaan is of patiënten uit de experimentele en kontrole konditie onderling op een aantal kenmerken verschillen zoals, leeftijd, geslacht, opleidingsnivo en opnameduur. Dit blijkt niet het geval te zijn.

Het blijkt dat wanneer we de meningen van patiënten en verpleegkundigen van experimentele eenheden vergelijken met de mening van patiënten en verpleegkundigen van kontrole eenheden, er op experimentele eenheden meer volgens het model Integrerende Verpleegkunde wordt gewerkt. Wat patiënttoewijzing betreft, zijn de verschillen groot en ten aanzien van 'het systematisch verpleegkundig handelen' en het expliciet betrekken van patiënten bij de zorg zijn de verschillen klein.

Het blijkt dat na opname patiënten uit de twee kondities niet verschillen in de mate waarin zij vinden dat zij invloed hebben op de verzorging. Voor ontslag ervaren patiënten van experimentele eenheden meer invloed dan patiënten uit de kontrole konditie. Dit komt ondat patiënten van experimentele eenheden tijdens het verblijf meer invloed gaan ervaren en patiënten van kontrole eenheden niet. Verwacht werd dat indien patiènten meer invloed waarnemen op hun verzorging, zij ook meer invloed zullen gaan ervaren op aspecten die aan de verzorging zijn gerelateerd, zoals het 
lichamelijk herstel en de eigen gezondheid in het algemeen. De gegevens ondersteunen deze verwachting niet. Verwacht werd dat het ervaren van meer invloed ook zou leiden tot een toename van zelfzorgaktiviteiten, meer kennis bij patiënten over ziekte en behandeling, en een meer probleemoplossende houding ten aanzien van de eigen gezondheid. Op experimentele eenheden blijken patiënten alleen meer zelfzorgaktiviteiten te verrichten. Wel blijkt dat patiënten in beide kondities tijdens het verblijf in het ziekenhuis meer initiatieven gaan ontplooien en beter geïnformeerd raken over ziekte en behandeling. Verwacht werd dat naarmate de opname langer duurt de mening wan patiënten uit de twee kondities vóór het ontslag verder uit elkaar zouden liggen. Dit blijkt alleen zo te zijn ten aanzien van het verrichten van zelfzorgaktiviteiten. Ook hier blijkt dat in beide kondities men meer initiatief ontplooit, zich meer probleemoplossend opstelt en zich beter geïnformeerd acht, naarmate de opname langer duurt. Tenslotte werd voorspeld dat patiënten die bij opname verwachten veel invloed uit te kumnen oefenen op de verzorging op experimentele eenheden weinig en op kontroje eenheden veel stress ervaren. Dit blijkt niet zo te zijn. Wel neemt tijdens het verblijf de door patiënten ervaren stress in beide kondities af. Uit een secundaire analyse blijkt dat patiënten die bij opname van mening zijn dat het verloop van het verblijf in het ziekenhuis wordt bepaald door artsen, verpleegkundigen en patiënten tezamen, op experimentele eenheden minder stress ervaren dan op kontrole verpleegeenheden. Gekonkludeerd wordt dat de verschillen tussen de reakties van patiënten uit de twee kondities over het geheel genomen niet erg groot zijn.

In het zesde hoofdstuk wordt eerst de inhoud van de vragenlijst besproken die werd voorgelegd aan verpleegkundigen, de verpleegkundige leiding en artsen. In totaal werden door verpleegkundigen 435 vragenlijsten ingevuld. Daarvan is $41 \%$ afkomstig van de experimentele eenheden. Het response percentage is in beide kondities gelijk (74\%). Door leidinggevenden werden 57 vragenlijsten ingevuld (40\% van experimentele eenheden) en door artsen 70 (31\% van experimentele eenheden). De respondenten van de experimentele en de kontrole eenheden verschillen onderling niet wat betreft bijvoorbeeld de ervaring of de verhouding van mannen en vrouwen. De verpleegkundigen van experimentele eenheden blijken alleen gemiddeld iets ouder (29.1 jaar ten opzichte van 27.1 jaar op de kontrole eenheden).

Het blijkt dat verpleegkundigen van experimentele eenheden meer handelingsruimte ervaren op het terrein van het uitvoeren wan verpleegtechnische verrichtingen, luet beleid van de eenheid en het zelfstandig kunnen werken. Van deze ruimte maken ze grotendeels ook gebruik. Naar voren komt dat de verpleegkundigen, de leiding, de artsen en de patiënten op experimentele eenheden meer dan de respondenten van de kontrole eenheden vinden dat verpleegkundigen invloed hebben op de zorg. Verpleegkundigen van experimentele eenheden worden vooral vaker bij overleg over de zorg aan individuele patiënten betrokken en kunnen. in grotere mate zelfstandig beslissingen nemen in de zorg. Verpleegkundigen van experimentele eenheden zijn in hun funktioneren minder afhankelijk van kollega's terwijl de leiding en artsen zich in hun funktioneren in de experimentele konditie meer afhankelijk voelen van verpleegkundigen.

Nagegaan is in welke mate de invloedspositie van verpleegkundigen verklaard kan worden door de ervaring van verpleegkundigen, de bekwaamheid van verpleegkundigen en enkele andere variabelen. In de beleving van verpleegkundigen hangt de eigen 
machtspositie samen met de eigen bekwaamheid en met de mate waarin men zich gebonden acht aan het realiseren van verpleegkundige innovaties. Leiddinggevenden en artsen associëren een hogere machtspositie van verpleegkundigen met het algemeen oordeel over het funktioneren van die verpleegkundige en de mate waarin de verpleegkundige zich in de samenwerking koöperatief opstelt. Uit een secundaire analyse blijkt dat artsen in de experimentele konditie zich meer negatief uitspreken over verpleegkundigen en dat dit verklaard kan worden door de bevinding dat zij met meer verschillende verpleegkundigen moeten overleggen, hetgeen als tijdrovend wordt ervaren.

Verwacht werd dat de introduktie van Integrerende Verpleegkunde onzekerheid zou kunnen veroorzaken bij verpleegkundigen betreffende de nieuwe taken. Uit de verzamelde gegevens blijkt dat dit niet het geval is. Ook de minder ervaren en minder geschoolde verpleegkundige ervaart door de taakverruiming niet meer onzekerheid over het eigen funktioneren. De behoefte aan overleg met kollega's over onzekerheden in het werk is op experimentele eenheden dan ook niet groter. Een aantal relevant geachte kondities, zoals de ervaren instrumentaliteit van overleg en de verwachting dat kollega's vergelijkbare onzekerheden in hun funktioneren ervaren, blijkt niet samen te hangen met de behoefte aan overleg. Wel blijkt dat verpleegkundigen die aangeven recentelijk over onzekerheden in het werk met kollega's te hebben gesproken, minder onzekerheid ervaren. Gekonkludeerd kan worden dat de introduktie van het model heeft geleid tot taakverruiming en dat de verpleegkundigen door de introduktie meer invloed hebben gekregen. Bovendien heeft de taakverruiming geen problemen bij individuele verpleegkundigen veroorzaakt.

In het zevende hoofdstuk worden de gevolgen van Integrerende Verpleegkunde voor andere kategorieën personen in het ziekenhuis besproken. Het blijkt dat de introduktie van het model vooral van invloed is geweest op de positie van de verpleegkundige leiding. Met name de taken die de direkte patiëntenzorg betreffen heeft de leiding gedelegeerd aan verpleegkundigen. Verpleegkundigen en artsen overleggen minder met de verpleegkundige leiding voor zover het gaat om de zorg aan individuele patiënten. De invloed van de leiding op het beleid van de eenheid is op experimentele eenheden niet kleiner dan op kontrole eenheden. De positie van de arts is als gevolg van Integrerende Verpleegkunde niet of nauwelijks veranderd. De zaalarts, veelal een medisch specialist in opleiding, is frekwent op de eenheid en bemerkt dat de verandering van de positie van de verpleegkundige niet zozeer zijn of haar positie bedreigt, maar wel tot gevolg heeft dat hij of zij meer tijd kwijt is om een verpleegkundige te vinden die de verantwoordelijkheid draagt voor de zorg van een specifieke patiënt.. De artsen vinder de kwaliteit van de informatie die verpleegkundigen op experimentele eenheden verstrekken beter, maar ervaren het als negatief dat de verpleegkundige en daarmee de informatie moeilijk is te bereiken. De positie van de medisch specialist lijkt geheel niet veranderd. De medische registratie-assistent lijkt op experimentele eenheden wel een iets andere rol te hebben. Vooral artsen ervaren een grotere afhankelijkheid van de medische registratie assistent. Mogelijk dat artsen, wanneer zij een verpleegkundige die een specifieke patiënt verzorgt niet kunnen vinden, zich vaker richten -over bijwoorbeeld uitslagen van een laboratorium onderzoek- tot de medische registratie-assistent voor informatie.

In het laatste hoofdstuk worden enkele methodologische aspekten van het onderzoek 
belicht. Ook wordt ingegaan op de theoretische en praktische betekenis van de studic.

Het is gebleken dat de ervaringen van patiënten uit de experimentele konditie niet sterk verschillen van de ervaringen wan patienten van kontrole verpleegeenheden. Uit enkele secundaire analyses blijkt dat binnen de kontrole konditie, lopende het onderzoek, elementen van Integrerende Verpleegkunde zijn geintroduceerd. Ook is gebleken dat het model op experimentele eenheden niet volledig is ingevoerd. Met name worden patiënten nog weinig expliciet en systematisch bij de zorg betrokken. Verder komt naar voren dat ook in de kontrole konditie bij patiënten wenselijke veranderingen optreden, zoals stressreduktie, een grotere betrokkenheid en een toename van de kennis over de ziekte en de behandeling. Het verzamelde materiaal wijst er met andere woorden niet op dat patiënten in een ziekenhuis zonder Integrerende Verpleegkunde zich hulpeloos gaan voelen. Er wordt verder op gewezen dat, ook indien het model optimaal ingevoerd zou zijn, de gevolgen voor patiënten waarschïnlijk beperkt zullen zijn, omdat gezien de gemiddelde leeftijd van patiënten, de houding van patiënten ten aanzien van het gezondheidsgedrag tamelijk sterk zal zijn verankerd. Een kort verblijf in een ziekenhuis zal dit niet ingrijpend kumen veranderen. Bovendien is de verpleegkundige zorg maar éen van de faktoren -naast bijvoorbeeld de medische behandeling-- waardoor de houding van een patiënt gedurende het verblijf wordt beinvloed.

De resultaten wijzen er op dat de introduktie van Integrerende Verpleegkunde met name invloed heeft gehad op de inhoud van de werkzaamheden van de verpleeg. kundige en de positie van verpleegkundigen en de verpleegkundige leíding. De verpleegkundige heeft een grotere verantwoordelijkheid gekregen in de direkte patiëntenzorg. De verpleegkundige leiding nicht zich primair op het beleid van de eenheid. Bij een verdere implementatie van het model vragen een aantal aspecten extra aandacht. In de eerste plaats zal de participatie van patiënten meer moeten worden gestimuleerd. Daarnaast is het van belang dat tijdens de introduktie van het model de verpleegkundige leiding intensief wordt ondersteund. De resultaten wijzen er verder op dat training of bijscholing gewenst is ten aanzien van het methodisch werken, met name voor de wat oudere verpleegkundige. Tenslotte wordt er op gewezen dat het voor de verpleegkundige discipline van belang is dat artsen en andere leden van de organisatie de veranderingen positief (gaan) beoordelen. Onderdelen die bijdragen tot een negatief oordeel, zoals de bereikbaarheid van verpleegkundigen, vragen meer aandacht.

Gekonkludeend wordt dat de invoering van Integrerende Verpleegkunde voor een deel is geslaagd en dat dit een aantal wenselijke veranderingen met zich mee heeft gebracht voor patiënten, maar met name voor verpleegkundigen. Aanbevolen kan worden het model (verder) in te voeren, maar men zall daarbij de bovengenoemde aspekten meer aandacht moeten geven. 


\section{SUMMARY}

This dissertation deals with the effects of the introduction of the Integrated Nursing model in some nursing units of a hospital. These effects involve the ones on patients, nurses, nursing staff and on a few other disciplines and groups within the hospital organization. The model was introduced in four nursing units of the University Hospital of Groningen in the period from 1983 to 1985 . In this period patients, nurses, nursing staff and doctors were asked to fill in a questionnaire at three instants. For the purpose of comparison this questionnaire was also given at about the same moments to patients, nurses, staff and doctors of seven mursing units to which the model had not been introduced. These concern five nursing units of the same hospital and two nursing units of another University Hospital.

Chapter 1 gives a short sketch of the previous history. In it some changes are discussed which took place in the nursing organization within hospitals in the past few decades, and which contributed to the fact that a strong need for a professionalization of the job arose within the nursing discipline. Integrated Nursing can be considered an exponent of this professionalization.

Integrated Nursing intends to improve the quality of patient care, to stimulate professional development, and to promote the possibilities for development for individual nurses. In traditional nursing -also called functional nursing-- nurses were assigned tasks. They perform these tasks for a great number of different patients within the nursing unit. These tasks are directed towards the different nursing needs of a patient. On the one hand this working organization results in frequently insufficient attention for the coherence between the different elements of the patient's problem. Integrated Nursing stresses the integral approach of the patient's problems, and consequently the integration of the nursing tasks which result from them. On the other hand does the traditional division of labour imply an extensive task and job differentiation, which may lead to a situation in which nurses no longer recognize the purport of their own tasks in the whole of the treatment of the patient, and become discouraged. Integrated Nursing strives for a horizontal and vertical extension of responsibilities: nurses become responsible for the overall nursing care of a few patients.

The two main instruments of Integrated Nursing are:

the assignment of patients. This means that an individual nurse is not performing a limited number of tasks for a great number of patients, but is responsible for the overall care of a few patients.

-the Nursing Process (systematic nursing). This implies that a nurse systematically and in consultation with the patient defines the needs, sets the objectives, plans the work, ascertains the results of the actions, and subsequently, if necessary, adjusts the plan.

The first chapter also deals with a few studies in which the Integrated Nursing model or similar working models have been examined. Most studies show- mostly in general terms like 'satisfaction'-- that the introduction of these models had a positive effect on the patients and the nurses. These results, however, offered few pretexts to formulate specific hypotheses. Therefore only a few preliminary questions are 
formulated in the first chapter. It is expected that through Integrated Nursing patients will have a greater influence on the manner in which they are nursed and that the introduction of the model will strengthen the position of the nurses in the hospital. The expectation that this extension of responsibilities will cause insecurity with less experienced or less well-trained nurses is also formulated.

The second chapter elaborates on the expected effects of Integrated Nursing on patients. For this purpose use is made of the viewpoints from the social doctrine, and more specifically from the doctrine of learned helplessness. On the basis of empiricism based on these theories the effects of hospitalization in a situation without Integrated Nursing are first described. In this situation a patient is not expected to have an active attitude, and the patient is not explicitly involved in solving his or her health problems. Besides, the patients come into contact with many different health workers all carrying out parts of the task. This is one of the reasons why patients feel that they have little influence on the communication with health workers and on the purport of nursing care. They may begin to feel powerless and dependent on doctors and nurses, and no longer experience responsibility for the outcome of their stay in hospital. According to the doctrine of learned helplessness this will lead to depersonalization and depression.

It is predicted that with Integrated Nursing patients will begin to experience that they have a greater influence on the way they are nursed, and therefore will begin to feel more responsible for the outcome of the nursing and their physical recovery. It is expected that when an increase in influence is observed, this will also lead to the patients showing more initiative in interactions with health workers, to them becoming better informed on their illnesses and their treatment, and to them beginning to display more self-care activities. The latter, for instance, in terms of 'washing yourself' or 'taking your own temperature'. Because nurses plan and execute their jobs in their contacts with patients in accordance with the Nursing Process, it is expected that patients will (also) begin to approach their own health problems in a more problemsolving manner. Furthermore it is expected that the longer a patient remains in a hospital, the stronger the effects mentioned above will manifest themselves. Finally this chapter differentiates between patients who, at the moment of admission, expect to have a lot of influence and those who expect to have little or no influence on the nursing care. Persons from the latter group will likely conform themselves, whatever the nursing method will be. Patients who expect that they are able to exercise influence will become disappointed and depressed in a situation without Integrated Nursing, whereas this will not happen in a situation with this model.

In the third chapter the hypotheses about the effects of Integrated Nursing on nurses and some other groups of hospital employees are formulated. The Expectation States Theory is used, which offers insight into the manner in which power relations within groups originate, and the power theory which stresses the possibilities of an individual or a group of persons to strengthen the private positions of power. The expectations are that as a result of the extension of responsibilities the nurse will contribute in a greater extent to patient care. In the theories mentioned this contribution is considered an important determinant of the position of power. A strengthening of the position of power may, among other things, appear from the greater influence on decisions taken. Some conditions are discussed which may promote 
or obstruct this strengthening of the position of power. In that respect the expectations are that a positive judgement of others within the organization with regard to the contribution is of great importance, and that nurses will adopt a co-operative but also confident attitude in the teamwork. Furthermore it is expected that it will be easier for nurses with a higher seniority and more capabilities to gain a greater influence. It is also expected that as murses consider themselves more committed to successfully carry through nursing innovations, their motivation to gain and retain a greater influence will be better.

Research on the effects of promotion of members of an organization participating in the constitution of policies and decision-making in companies have shown that the strengthening of power of one particular individual does not necessarily imply that this will be at the expense of another person's position. Others will resist the increase of the influence of nurses less, if the individual position of influence is not being threatened. It is therefore important to examine the effects of Integrated Nursing on the positions of other groups within the organization.

In the last part of the third chapter attention is given to the problems which may arise for the individual nurse as a result of the extension of duties and responsibilities. The expectations are that especially nurses with less experience and less schooling will feel insecure or uncertain with respect to the new duties, like coordination of nursing and co-operation with doctors. The importance of the contacts with colleagues in order to decrease this insecurity is discussed with the use of the Social Comparison Theory. The expectations are that when insecurity is experienced the need to discuss this with colleagues will increase. This increase will be greater under certain conditions. The need will for instance be stronger when a nurse assumes that colleagues will experience similar insecurities, or considers consultation as an instrument to reduce insecurities, and if people in the nursing unit have a positive attitude towards consultation between colleagues. Furthermore it is expected that nurses with a positive self-image will consider it less threatening to put forward insecurities about how they function personally.

Chapter 4 deals with the research method. The first part discusses the manner in which the experimental units and the control units -- the ones to which the developments in the experimental units are compared -- were selected. The conclusion is that the selection of the units was not a random one, and that there was no random assignment of units to the two conditions. It is supposed that the selection may have influenced the nurses" reactions, but not or to a lesser degree the patients' and cloctors' reactions.

The data were collected in May/June 1984, November/December 1984 and May/June 1985 by means of questionnaires. Because of various practical circumstances the first measurement took place 6 months after the project had formally started. The last measurement took place some months before the project was formally terminated. This study will therefore not speak of pre-, intermediate and post-measurements, although this was originally the intention. Some other possibly relevant methodological problems will be discussed as well. These deal with the possibility that there may have been a diffusion of the conditions, because for instance nurses from two conditions exchanged experiences, and control units introduced elements of Integrated Nursing. Also the fact that the respondents (and especially the nurses) were mostly aware of the 
research situation may have influenced their reactions.

The last part of the fourth chapter discusses the procedure used. During each of the three measuring periods all nurses, staff members and medical specialists from both conditions were asked to record their experiences in a questionnaire. The ward doctors --mostly medical specialists in training-- gave their reactions at the end of their three- or six-month training period in their particular unit. The patients were offered a questionnaire the day after their admission and the day before their discharge. All respondents returned the completed questionnaire in a closed envelope.

In chapter 5 the effects on patients are discussed. The first paragraph deals with the contents of the questionnaire. Next, the selection of patients is discussed. In the course of the period the patients were approached, more than 1600 patients were adritted in the units that were involved in the research. For various reasons about 1000 of these patients have not participated in the research. In most of these cases either the expected period of admission was too short (49\%), or the patient was physically or mentally unable to participate in the research $(13 \%)$, or the patient himself or herself indicated that he or she did not want to participate in the research $(8 \%)$. It is checked whether there were any differences between the patients in the experimental and the control conditions with regard to certain aspects like age, sex, level of education, and period of admission. This proves not to be the case.

It appears that, if we compare the opinions of the patients and the nurses of the experimental units with those of the patients and nurses of the control units, the experimental units worked more according to the Integrated Nursing model. The differences are substantial with respect to patient assignment, and minor with respect to the Nursing Process and explicitly involving patients in the nursing care.

It appears that after admission there is no difference in the degree in which patients from either condition think that they have influence on the nursing care. Before discharge patients from the experimental units feel that they have had a greater influence than patients from the control condition do. The reason for this is that patients from experimental units experience a greater influence in the course of their stay, whereas patients of the control units do not have this experience. The expectations were that if patients discover that they have a greater influence on their nursing, they will also begin to experience a greater influence on aspects related to the nursing, like physical recovery and the private health in general. The outcome does not support these expectations. The expectations were that experiencing a greater influence would lead to an increase of self-care activities, a greater knowledge with the patient about the illness and the treatment, and a more problem-solving attitude towards the private health. The experimental units have shown that patients only performed more self-care activities. However, it appears that during their stay in hospital patients in both conditions show more initiatives, and become better informed about their illnesses and treatments. The expectations were that as the stay would take longer the opinions of the patients from the two conditions would be further apart just before the discharge. This appears to be only with respect to performing self-care activities. Here too appears that in both conditions patients show more initiative, have a more problemsolving attitude and consider themselves better informed as the admission takes longer. Finally the predictions were that patients who expect to be able to exercise a lot of influence on the nursing experience little stress in the experimental units and a lot of 
stress in the control ones. This appears not to be the case. The stress experienced by the patients, however, does decrease in the course of the stay in both conditions. From a secondary analysis it appears that patients who are of the opinion that the course of the stay is determined by doctors, nurses and patients together experience less stress in experimental units than similar patients in control units do. The conclusion is, that generally speaking the differences between the reactions of the patients from the two conditions are not very big.

In the sixth chapter the contents of the questionnaire put to nurses, nursing staff and doctors is discussed first. The nurses handed in 435 questionnaires in all. $41 \%$ of these are from the experimental units. The return percentage was identical for both conditions $(74 \%)$. The staff members filled in 57 questionnaires (40\% from the experimental units), and doctors $70(31 \%$ from the experimental units). The respondents from the experimental and control units are similar with respect to for instance experience or man/woman ratio. The nurses from the experimental units, however, appear on average to be slightly older (29.1 to 27.1 ).

It appears that nurses from experimental units experience more room to act where the performance of nursing activities, the policy of the unit and the ability to work independently are concerned. For the main part they have used this space. What appears is that, more than the respondents from the control units, the nurses, staff, doctors and patients from the experimental units feel that nurses have an influence on the treatment. Nurses in the experimental units especially are more often included in the consultation about the treatment of individual patients, and they are to a greater extend able to take decisions about the treatment independently. In their functioning nurses from experimental units are less dependent on their colleagues, whereas staff and doctors in the experimental units feel that their functioning is more dependent on the nurses.

It has been researched to which extend the experience of nurses, their capabilities and some other variables explain the position of influence of nurses. The nurses themselves consider the individual position of power to be related to their own capabilities, and to the degree in which they feel committed to realize nursing innovations. Staff and doctors associate a higher position of power of nurses with the general judgement about the functioning of that particular nurse, and the degree in which a nurse is co-operative in the teamwork. From a secondary analysis it appears that doctors in the experimental condition give a more negative opinion about nurses; this can be explained by the fact that they have to consult more and different nurses, which is considered time-consuming.

The expectations were that the introduction of Integrated Nursing could cause insecurity with nurses with regard to the new tasks. The data gathered show that this is not the case. The less experienced and Jess schooled nurse does not feel any more insecurity about the own functioning as a result of the extension of responsibilities either. The need for consultation with colleagues about insecurities about the work is therefore not greater on the experimental units. A number of conditions, which were considered relevant; like the experienced instrumentality of consultation and the expectation that colleagues would experience similar insecurities in their functioning, appear not to be connected with the need for consultation. It does appear, however, that nurses who have recently spoken with colleagues about insecurities about their 
jobs; experience less insecurity. It may be concluded that the introduction of the model has led to an extension of responsibilities, and that through the introduction nurses have gained more influence. Moreover, the extension of responsibilities did not cause problems for individual nurses.

The seventh chapter discusses the effects of Integrated Nursing on other categories of persons in the hospital. It appears that the introduction of the model especially influenced the position of the nursing staff. Particularly tasks involving direct patient care were delegated to nurses by the staff. The nursing staff is consulted less by nurses and doctors when the treatment of individual patients is concerned. The staff's influence on the policies of the units is no less in the experimental units than in the control units. The position of the doctor has not or hardly changed as a result of Integrated Nursing. The ward doctor, mostly a medical specialist in training, is frequently present in the unit, and notices that the change in the position of the nurse not so much threatens his or her position, but does result in him or her wasting more time in trying to locate a nurse who is treating a particular patient. The doctors consider the information given in the experimental units of a better quality, but they consider it a negative aspect that it is harder to locate the nurse and consequently the information. The position of the medical specialist does not appear to have changed at all. The medical registration assistant seems to have a slightly different role in the experimental units. Especially doctors experience a greater dependence on the medical registration assistant. It is possible that doctors will direct themselves more often to medical registration assistants for information --for instance on laboratory resultswhen they are unable to locate a nurse who is treating a particular patient.

The last chapter deals with some methodological aspects of the research. The theoretical and practical meaning of the study is discussed as well.

It has appeared that the experiences of the patients from the experimental condition did not differ greatly from the experiences of the patients from the control nursing units. Some secondary analyses show that during the course of the research elements from Integrated Nursing were introduced to the control condition. It also appeared that the model was not fully introduced in the experimental units, notably the fact that patients are still too little involved explicitly and systematically in the treatment. Furthermore the control condition also shows desirable changes for the patients, like stress reduction, a greater involvement and an increase in the knowledge about the illness and the treatment. In other words, the material collected does not indicate that patients will begin to feel helpless in a hospital without Integrated Nursing. Furthermore it is pointed out that even if the model would have been introduced optimally, the effects on the patients would probably have been limited, because in view of the average age of the patients, the patients' attitudes towards health behaviour will be firmly rooted. A short stay in hospital will not substantially change this attitude. Besides, nursing care is only one of the factors --besides, for instance, medical treatment-- which will influence the patient's attitude during the stay.

The results show that the introduction of Integrated Nursing especially influenced the purport of the nursing tasks of the nurses and the positions of the nurses and the nursing staff. The nurse has gained more responsibility with respect to direct patient care. The nursing staff will primarily concern itself with the policy of the unit. If the model is implemented further, certain aspects will require special attention. 
In the first place patient participation will have to be stimulated more. It is also important that in the course of the introduction of the model the nursing staff will be supported intensively. The results furthermore show that training or extra schooling is desirable with regard to the Nursing Process, especially in the case of the slightly older nurse. Finally it is pointed out that it is important for the nursing discipline, that doctors and other members of the organization (begin to) judge the changes positively. Elements contributing to a negative judgement, like the accessibility of murses, demand more attention.

It is concluded that the introduction of Integrated Nursing has been partly successful, and that it has led to a number of desirable changes for patients, but especially for nurses. "The advice may be to (further) introduce the model, but to give more attention to the aspects mentioned. 


\section{REFERENTIES}

Aukes, L.C., Baving, J.E. \& Molleman, E. Het Nieuwkomersonderzoek Groningen: Academisch Ziekenhuis Groningen, 1987.

Austin, R. Professionalism and the nature of nursing reward. Joumal of Advanced Nursing, $1978,3,9-23$.

Baider, L. \& Porath, S. Uncovering fear: Group experience of nurse in a cancer ward. Inernational Joumal of Nursing Studies, 1981, 18, 47-52.

Baltes, M.M. \& Skinner, E.A. Cognitive performance deficits and hospitalization: Learned helplessness, instrumental passivity, or what? Comment on Raps, Peterson, Jonas, and Seligman. Journal of Personality and Social Psychology, 1983, 45, 10131016.

Baum, A., Aiello, J.R. \& Calesnick, L.E. Crowding and personal control: Social density and the development of learned helplessness. Joumal of Personality and Social Psychology, 1978, 36, 1000-1011.

Baum, A. \& Valins, S. Architectural mediation of residential density and control: Crowding and the regulation of social contact. In L. Berkowitz (Ed.), Advances in Experimental Social Psychology (Vol. 12). New York: Academic Press, 1979.

Berger, J., Conner, T.L. \& Fisek, M.H. (Eds.). Expectation States Theory: A Theoretical Research Program. Cambridge, Mass.: Winthrop, 1974.

Berger, J. Fisek, M.H., Norman, R.Z. \& Zelditch, M. Status characteristics and social interaction: An expectation states approach. New York: Elsevier, 1977.

Berger, J., Rosenholtz, S.J. \& Zelditch, M. Status organizing processes. Annual Review of Sociology, 1980, 6, 479-508.

Berry, A.J. \& Metcalf, C.L. Paradigms and pratices: The organisation of the delivery of nursing care. Joumal of Advanced Nursing, 1986, 11, 589-597.

Bodt, J.H.I. \& Tuijl, H.F.J.M. Het optimaal organiseren van een verpleegafdeling. Tijdschrift voor Sociale Gezondheidszorg, 1985, 63, 622-626.

Boschma, G. Rationaliteit van Verpleegkundige Zorg. Groningen: Faculteit der Wijsbegeerte, Rijks Universiteit Groningen, 1988.

Bowers, L. The significance of primary nursing. Journal of Advanced Nursing, 1989, 14, 13-19.

Brickman, P., \& Bulman, R.J. Pleasure and pain in social comparison. In J.M. Suls \& R.L. Miller (Eds.), Social Comparison Processes: Theoretical and Empirical Perspectives. Washington, DC: Hemisphere, 1977.

Brouns, G. Orem's zelfzorgtheorie. Verpleegkunde, 1988, 1, 27-32.

Burger, J.M. \& Arkin, R.M. Prediction, control, and learned helplessness. Journal of Personality and Social Psychology, 1980, 38, 482-491.

Castore, C.H. \& DeNinno, J.A. Investigations in the social comparison of attitudes. In J.M. Suls \& R.L. Miller (Eds.), Social Comparison Processes: Theoretical and Empinical Perspectives. Washington, DC: Hemisphere, 1977.

Chemers, M.M., Hays, R.B., Rhodewalt, F. \& Wysocki, J. A person-environment analysis of job stress: A contingency model explanation. Journal of Personality and 
Social Psychology, 1985, 49, 628-635.

Conolley, E.S., Gerard, H.B. \& Kline,T. Competitive behavior, A manifestation of motivation for ability comparison. Journal of Experimental Social Psychology, 1978, 14, 123-131.

Cook, T.D. \& Campbell, D.T. Quasi-Expenimentations: Design \& Analysis: Issues for Field Settings. Boston: Houghton Mifflin Company, 1979.

Cottreil, N.B. \& Epley, S.W. Affiliation, social comparison, and socially mediated stress reduction. In J.M. Suls \& R.L. Miller (Eds.), Social Comparison Processes: Theoretical and Empirical Perspectives. Washington, DC: Hemisphere, 1977.

Darley, J.M. \& Latané, B. Bystander intervention in emergencies: Diffusion of responsibility. Joumal of Personality and Social Psychology, 1968, 8, 377-383.

Dickoff, I. \& James, P. A theory of theories: A position paper. Symposion on theory development in nursing. Nursing Research, 1968, 17, 197-203.

Diemert Moch, S. Towards a personal control/uncontrol balance. Journal of Advanced Nursing, $1988,13,119-123$.

Diener, C.I. \& Dweck, C.S. An analysis of learned helplessness: Continuous changes in performance, Strategy, and achievement cognitions following failure. Journal of Personality and Social Psychology, 1978, 36, 451-462.

Eindhoven, van A. Cultuur-historische wortels van de verpleging. Tijdschrift voor Bejaarden-, Kraam- en Ziekenverzorging, 1980, 13, 315-323.

Eiser, J.R. Social Psychology, Attitudes, Cognitions an Social Behaviour. Cambridge (UK): Cambridge University Press, 1986.

Emans, B. Machtgebruik: Onderzoek naar Empirisch Onderscheidbare soorten wan Machtgebruik. Groningen: Proefschrift Rijksuniversiteit Groningen, 1988.

Emans, B. \& den Boer, D.J. Integrerende Verpleegkunde en de relatie tussen verpleegkundigen en leidinggevenden. Acta Hospitalia, 1988, 28, 5-15.

Faucheux, C. \& Mackenzie, K.D. Task dependency of organizational centrality: Its behavioral consequences. Journal of Experimental Social Psychology, 1966, 2, 361375.

Festinger, Ln A theory of social comparison processes. Human Relations, 1954, 7, 117140.

Fiedier, F.E. A Theory of Leadership Effectiveness. New York: McGraw-Hill, 1967.

Finney, J.W., Mitchell, R.E., Cronkite, R.C. \& Moos, R.H. Methodological issues in estimating main and interactive effects: Examples from coping/social support and stress field. Journal of Health and Social Behavior, 1984, 25, 85-98.

Fishbein, M. \& Ajzen, I. Belief, Attitude, Intention and Behavior: An Introduction to theory and Research. Reading: Addison-Wesley Publishing Company, 1975.

Fleming, R., Baum, A. \& Singer, J.E. Towards an integrative approach to the study of stress. Joumal of Personality and Social Psychology, 1984, 46, 939-949.

Folkman, S. Personal control and stress and coping processes: A theoretical Analysis. Joumal of Personality and Social Psychology, 1984, 46, 839-852.

Folkman, S. \& Lazarus, R.S. An analysis of coping in a middle-aged community sample. Joumal of Health and Social Behavior, 1980, 21, 219-239.

Fox, S. Situationall determinants in affiliation. European Journal of Social Psychology, $1980,10,303-307$.

Garber, J. \& Seligman, M.E.P.(Eds.), Human Helplessness, Theory an Applications. New 
York: Academic Press, 1980.

Georgopoulas, B.S. Organization Research in Health Institutions. Ann Arbor: The Insitute for Social Research, The University of Michigan, 1974.

Gerard, H.B. Emotional uncertainty and social comparison. Journal of Abnomal and Social Psychology, 1963, 66, 568-573.

Goethals, G.R. Social comparison theory: Psychology from the lost and found. Personality and Social Psychology Bullerin, 1986, 12, 261-278.

Gordon, B.F. Influence and social comparison as motives for affiliation. Journal of Experimental Social Psychology, 1966, Supplement 1, 55-65.

Groot, de, A.D. Methodologie: Grondslagen van onderzoek en deniken in de gedragswerenschappen. 's-Gravenhage: Mouton, 1961.

Gruder, C.L. Choice of comparison persons in evaluating oneself. In J.M. Suls \& R.L. Miller (Eds.), Social Comparison Processes: Theoretical and Empirical Perspectives. Washington, DC: Hemisphere, 1977.

Grypdonck, M. Integrerende Verpleegkunde, een situatie scheppende theorie. In $\mathrm{H}$. van der Bruggen (Ed.), De Delta van de Nederlandse Verpleging, Lochem: De Tijdstroom, 1988.

Grypdonck, M., Rodenbach, M.Th. \& Windey, T. Het model integrerende verpleegkunde: Een woorstel tot heroriëntering. Acta Hospitalia, 1977, 17, 124-150.

Guiot, J.M. Some comments on social comparison processes. Journal of the Theory of Social Behaviour, 1978, 8, 29-43.

Hakmiller, K.L. Threat as determinant of downward comparison. Journal of Experimental Social Psychology, 1966, Supplement 1, 32-39.

Hofling, C.K. Brotzman, E. Dalrymple, S. Graves, N. \& Pierce, C.M. An experimental study in nurse physician relationship. The Joumal of Nervous and Mental Disease, $1966,142,171-180$.

Innes, J.M. Does the professional know what the client wants? Social Science \& Medicine, 1977, 11, 635-638.

Jenkinson, V.M. Group or team nursing. Nursing Times, January 1958, pp. 62-64; $92-$ 93.

Johnson, J.E. \& Leventhal, H. Effects of accurate expectations and behavioral instructions on reactions during a noxious medical examination. Joumal of Personality and Social Psychology, 1974, 29, 710-718.

Jones, E.S. A patient allocation trial. Nursing Times, March 1977, pp. 390-392.

Jones, W.J. Management by crisis or by objectives?-2. Nursing Times, March 1977, pp. 388-390.

Jones, E.E. \& Gerard, H.B. Foundations of Social Psychology. New York: John Wiley, 1967.

Kalisch, B.J. \& Kalisch, P.A. An analysis of the sources of physician-nurse conflicts. Joumal of Nursing Administration, 1977, 7, 50-57.

Katz, D. \& Kahn, R.L. The social psychology of organizations (2nd ed.). New York: Wiley, 1978.

Keddy, B., Jones Gilles, M., Jacobs, P., Burton, H. \& Rogers, M. The doctor-nurse relationship: An historical perspective. Joumal of Advanced Nursing, 1986, 11, 745753.

Keirse, M. Burn-out bij gezondheidswerkers. Tijdschrift voor Ziekenverpleging, 1987, 41, 


\section{$13-22$.}

Kitson, A.L. Indicators of quality in nursing care -an alternative approach. Joumal of Advanced Nursing, 1986, 11,133-144.

Koene, G., Grypdonck, M., Rodenbach, M.Th. \& Windey, T. Integrerende Verpleegkunde: Welenschap in Praktijk. Lochem: De 'Tujdstroom, 1980.

Koller, P.S. \& Kaplan, R.M. A two-process theory of learned helplessness. Joumal of Personaliy and Social Psychology, 1978, 36, 1117-1183.

Koochei, G.P. Adjustments and coping strategies among the caretakers of cancer patients. Social Work in Health Care, 1979, 5, 145-150.

Krantz, D.S., Baum, A. \& Wideman, M. Assessment of preferences for self-treatment and infomation in health care. Joumal of Personality and Social Psychology, 1980, $39,977-990$.

Lanceley, A. Use of controlling language in the rehabilitation of the eledery. Journal of Advanced Nursing, 1985, 10, 125-135.

Langer, E.J., Janis, I.L. \& Wolfer, J.A. Reduction of psychological stress in surgical patients. Journal of Experimental Social Psychology, 1975, 11, 155-165.

Lee, M.T. \& Ofshe, R. The impact of behavioral style and status characteristics on social influence: A test of two competing theories. Social Psychology Quarterly, 1981, 44, 73-82.

Ley, P. Memory for medical information. British Joumal of Social and Clinical Psychology, 1979, 18, 245-255.

Macdonald, M. Primary nursing: Is it worth it? Joumal of Advanced Nursing, 1988, 13, $797-806$.

Marks-Maran, D. Patient allocation versus task allocation in relation to the nursing process. Nursing Times, March 1978, pp. 413-416.

Maslach, C. \& Jackson, S.E. Burnout in health professions: A social psychological analysis. In G.S. Sanders \& J. Suls (Eds.), Social psychology of health and illness. Hillsclale, New Jersey: Lawrence Erlbaum Associates, 1982.

McIntosh, J. Processes of communication, information seeking and control associated with cancer: A selective review of the literature. Social Science \& Medicine, 1974, $8,167-187$.

Metcalf, C.A. Job satisfaction and organizational change in a maternity hospital. International Jounal of Nursing Studies, 1986, 23, 285-298.

Milgram, S. Behavioral study of obedience. Joumal of Abnormal and Social Psychology, $1963,67,371.378$.

Miller, A. Does the process help the patient? Nursing Times, January 1985, pp. 24-27. Miller, A.G. (Ed.), The social psychology of psychological research. New York: The Free Press, 1972.

Miller III, I.W. \& Norman, W.H. Learned helplessness in humans: A review and attribution-theory model. Psychological Bulletin, 1979, 86, 93-118.

Mils, R.T. \& Krantz, D.S. Information, choice, and reactions to stress: A field experiment in a blood bank with laboratory Analogue. Joumal of Personality and Sacial Psychology, 1979, 37, 608-620.

Molleman, E., Krabbendam, P.J., Annyas, A.A., Schraffordt Koops, H., Sleijfer, D.Th. \& Vermey, A. The significance of the doctor-patient relationship in coping with cancer. Social Science \& Medicine, 1984, 18, 475-480. 
Molleman, E. Pruyn, J. \& van Knippenberg, A. Social comparison processes among cancer patients. British Joumal of Social Psychology, 1986, 25, 1-13.

Molleman, E. \& van Knippenberg, A. Social and psychological aspects of haemophilia. Patient Ealucation and Counseling, 1987, 10, 175-189.

Molleman, E. \& van Knippenberg, A. Interpersoonlijke gevolgen van ziekte en handicap. In J. Von Grumbkow, D. Van Kreveld \& R. Van der Vlist (Eds.), Toegepaste sociale psychologie (deel 3). Amsterdam: Swets \& Zeitlinger, 1988.

Moss, N. Hospital units as social contexts: Effects on maternal behavior. Social Science \& Medicine, 1984, 19, 515-522.

Mulder, M. Het spel om de macht. Meppel: Boom, 1972.

Mulder, M. \& Wilke, H. Participation and power equalization. Organizational Behavior and Human Performance, 1970, 5, 430-448.

Newman, A. Actor-observer differences in perception of self-control. The Joumal of Social Psychology, 1978, 105, 199-204.

Nunnally, J.C. Psychometric theory. New York: McGraw-Hill, 1967.

Orem, D.E. Nursing: Concepts of pratice. New York: MoGraw Hill, 1971.

Orem, D.E Nursing: Concepts of practice (3rd ed.). New York: McGraw Hill, 1985.

Orne, M.T. Demand characteristics and the concept of quasi-controls. In R. Rosenthal

\& R.L. Rosnow (Eds.), Artifact in Behavioral Research. New York: Academic Press, 1969.

Parkes, K.R. Locus of control, cognitive appraisal and coping in stressful episodes. Journal of Personality and Social Psychology, 1984, 46, 655-668.

Peterson, C. \& Raps, C.S. Helplessness and hospitalization: More remarks. Joumal of Personality and Social Psychology, 1984, 46, 82-83.

Piliavin, I.M., Piliavin, J.A. \& Rodin, J. Costs, diffusion, and the stigmatized victim. Journal of Personality and Social Psychology, 1975, 32, 429-438.

Pittman, N.L. \& Pittman, T.S. Effects of amount of helplessness training and external-internal locus of control on mood and performance. Journal of Personality and Social Psychology, 1979, 37, 39-47.

Ploeg, van der H.M., Defares, P.B. \& Spielberger, C.D. Een Nedelandse bewerking van de Spielberger State Trait Anxiety Inventory: De zelfbeoordelingsvragenlijst. De Psycholoog, 1980, 8, 460-467.

Plumpton, M. Experiments in nurse-patient allocation. Nursing Times, March 1978, pp. 417-419.

Polit, D.F. \& Hungler, B.P. Nursing research: principles and methods (third edition). Philadelphia: J.B. Lippincott Company, 1987.

Querido, A. Godshuizen en gasthuizen. Amsterdam: Wetenschappelijke Uitgeverij Amsterdam, 1960.

Quinless, F.W. \& McDermott Nelson, M.A. Development of a measure of learned helplessness. Nursing Research, 1988, 37, 11-15.

Raps, C.S., Peterson, C., Jonas, M. \& Seligman, M.E.P. Patient behavior in hospitals: Helplessness, reactance, or both? Joumal of Personality and Social Psychology, 1982, 42, 1036-1041.

Richards, D.A. \& Lambert, P. The nursing process: The effect on patients' satisfaction with mursing care. Joumal of Advanced Nursing, 1987, 12, 559-562.

Ridgeway, C.L. Conformity, group-oriented motivation, and status attainment in small 
groups. Social Psychology Quarterly, 1978, 4I, 175-188.

Reading, A.E. The short term effects of psychological preparation for surgery. Social Science \& Medicine, 1979, 13, 641-654.

Rodin, J. \& Langer, E.J. Long-term effects of a control-relevant intervention with the institutionalized aged. Journal of Personality and Social Psychology, 1977, 35, 897902.

Roth, S. A revised model of learned helplessness in humans. Joumal of Personality, $1980,48,103-119$.

Rotter, J.B. Generalized expectancies for internal versus external control in reinforcement. Psychological Monographs, 1966, 80, 1-28.

Ruiter, de F. \& Visser, A.Ph. Rolspanning in de verpleegkundige opleiding: Vergelijking tussen in-service opleiding en HBOV. Gezondheid \& Samenleving, 1983, 4, 8288.

Salancik, G.R. \& Pfeffer, J. Uncertainty, secrecy, and the choice of similar others. Social Psychology Quarterly, 1978, 41, 246-255.

Schachter, S. The psychology of affiliarion. Standford California: Standford University Press, 1959.

Schulz, R. Some life and death consequences of percieved control. In J.S. Carroll \& J.W. Payne (Eds.), Cognitions and social behavior. Hillsdale, New Jersey: Lawrence Erlbaum Associates, 1976.

Schulz, R. \& Hartman Hanusa, B. Long-term effects of control and predictability-enhancing interventions: Findings and ethical issues. Joumal of Personality and Social Psychology, 1978, 36, 1194-1201.

Seligman, M.E.P. \& Maier, S.E. Failure to escape traumatic shock. Journal of Experimental Psychology, 1967, 74, 1-9.

Shaw, M.E. \& Costanzo, P.R. Theories of social psychology. New York: MoGraw-Hill, 1970.

Shipley, R.H., Butt, J.H., Horwitz, B. \& Farbry, J.E. Preparation for a stressful medical procedure: Effect of amout of stimulus prexposure and coping style. Joumal of Constiting and Clinical Psychology, 1978, 46, 499-507.

Simpson, K. \& Sears, R. Authority and responsibility dellegation predicts quality of care. Journal of Advanced Nursing, 1985, 10, 345-348.

Solomon, S. Holmes, D.S. \& McCaul, K.D. Behavioral control over aversive events: Does control that requires effort reduce anxiety and physiological arousal? Joumal of Personality and Social Psychology, 1980, 39, 729-736.

Spielberger, C.D., Gorsuch, R.L \& Lushene, R.E. STAI manual for the State-Trait Anxieny Inventory. Palo Alto, Ca: Consulting Psychologists Press, 1970.

SPSS-X user"s guide (2nd ed.). New York: McGraw-Hill, 1986.

Suls, J. Notes on the occasion of social comparison theory's thirtieth birthday. Personality and Social Psychology Bulletin, 1986, 12, 289-296.

Suls, J.M. \& Miller, R.L. Social Comparison Processes: Theoretical and Empirical Perspectives. Washington, DC: Hemisphere, 1977.

Tammeling, B.P. Het AZG jubileert. Groningen: Academisch Ziekenhuis Gromingen, 1978.

Tannenbaum A.S. Social psychology of the work onganization. Belmont, California: Wadsworth Publishing Company Inc., 1966. 
Tannenbaum, A.S., Kavcic, B. Rosner, M., Vianello, M. \& Wieser, G. Hierarchy in organizations. San Francisco: Jossey-Bass Publishers, 1974.

Taylor, S.E. Hospital Patient Behavior: Reactance, helplessness, or control. Journal of Social Issues, 1979, 35, 156-184.

Ten Berge, J.M.F. Difficulty factors, distributiuon effects, and the least squares simplex data matrix solution. Educational and Psychological Measurement, 1972, 32, 911920.

Thibaut, J.W. \& Kelley, H.H. The social psychology of groups. New York: Wiley, 1959. Thornton, D.A. \& Arrowood, A.J. Self-evaluation, self-enhancement and the locus of social comparison. Joumal of Experimental Social Psychology, 1966, Supplement 1, 40-48.

Tuijl, van H. \& Bodt, H. Omgevingsonzekerheid en afdelingsorganisatie. In J.W. Hoorn, J.B.A. Lettink, H.F.J.M. van Tuill, G. de Vries \& J.M.H. Vissers (Eds.), Structurering en beheersing van zorgprocessen: Bedrifskundig instrumentarium voor de ziekenhuismanager. Lochem: De Tijdstroom, 1988.

Veen, P. Mensen in Organisaties: Een inleiding in de organisatie psychologie. Deventer: Van Loghum Slaterus, 1982.

Veen, P. Macht en beînvloeding: Een overzicht. In P. Veen \& H.A.M. Wilke (Eds.), Zicht op macht. Assen: Van Gorcum, 1983.

Veen, P. Sociale psychologie toegepast: Van probleem naar oplossing. Alphen aan de Rijn: Samson, 1985.

Veen, P. \& Wilke, H.A.M. De kem van de sociale psychologie. Deventer: Van Loghum Slaterus, 1984.

Vliert, van de E., Huismans, S.E., Krijger, N.L. \& van der Leeuw, R. Evaluatieonderzoek naar verandering in denkkader. In J. Von Grumbkow, D. Van Kreveld \& P. Stringer (Eds.), Toegepaste sociale psychologie (deel 2). Lisse: Swets \& Zeitlinger B.V., 1986.

Vries-Griever, de A.H.G., Schmidt, S.H., Van Ekeren, C. \& Meijman, T.F. Techniek en Patientenzorg: Een Onderzoek naar de Invloed van nieuwe Technologieën op de Inhoud van het Verpleegkundig Werk in Ziekenhuizen. Groningen: Vakgroep Arbeidsen Organisatiepsychologie, Rijksuniversiteit Groningen, 1985.

Waitzkin, $H$. Information giving in medical care. Joumal of Health and Social Behavior, $1985,26,81-101$.

Waitzkin, H. \& Stoeckle, J.D. The communication of information about illness. Advances in Psychosomatic Medicine, 1972, 8, 180-215.

Wallston, K.A. \& Wallston, B.S. Who is responsible for your health? The construct of health locus of control. In G.S. Sanders \& J. Suls (Eds.), Social psychology of health and illness. Hillsdale, New Jersey: Lawrence Erlbaum Associates, 1982.

Wallston, K.A. \& Wallston, B.S. \& DeVellis, R. Development of the Multidemensional Health Locus of Control (MHLC) scales. Health Education Monographs, 1978, 6, $161-170$.

Ware, J.E., Brook, R.H., Davies-Avery, A., Williams, K.N., Stewart, A.L., Rogers, W.H., Donald, C.A. \& Johnston, S.A. Conceptualization and Measurement of Health for Adults in the Health Insurance Study: Volume 1, Model of Healuh and Methodology. Santa Monica: The Rand Corporation, 1980.

Warwick, D.P. \& Lininger, C.A. The sample survey: Theory and practice. New York: 
McGraw-Hill, 1975.

Weisman, A.D. \& Sobel, H.J. Coping with cancer through self-insrtuction: A hypothesis. Joumal of Human Stress, 1979, 5, 3-8.

Wheaton, B. Models for stress-buffering functions of coping resources. Journal of Health and Social Behawior, 1985, 26, 352-364.

Wheeler, L. \& Zuckerman, M. In J.M. Suls \& R.L. Miller (Eds.), Social Comparison Processes: Theoretical and Empirical Perspectives. Washington, DC: Hemisphere, 1977.

Wills, T.A. Discussion remarks on social comparison theory. Personality and Social Psychology Bulletin, 1986, 12, 282-288.

Wilson, N.M. \& Dawson, P. A comparison of primary nursing and team nursing in a geriatric long-term care setting. International Joumal of Nursing Studies, 1989, 26, $1-13$.

Winer, B,J. Statistical principles in experimental design (2nd ed.). New York: McGraw-Hill, 1971.

Wortman, C.B. Social support and the cancer patient: Conceptual and methodological issues. Cancer, 1984, 53, 2339-2362.

Wortman, C.B. \& Brehm, J.W. Responses to uncontrollable outcomes: An integration of reactance theory and the learned helplessness model. In L. Berkowitz (Ed.), Advances in Experimental Social Psychology (vol. 8). New York: Academic Press, 1975.

Zuroff, D.C. Learned helplessness in humans: An analysis of learning processes and the roles of individual and situational differences. Journal of Personality and Social Psychology, 1980, 39, 130-146. 


\section{BILAGE II}

Faktorladingen matrix wan een faktoranalyse over 14 items betreffende de verwachting van patienten dat zij zell of de verpleegkundige/arts invloed hebben op 'aan de zorg gerelateerde onderwerpea ${ }^{2}$. Br is een principale komponenten analyse witgewoerd met Varimax-rotatie. Ladingen groter dan 30 worden in de tabel gegeven. In het onderste deel wordt een overzicht gegeven wan de eigenwalarden en de verklaarde variantie van de cerste 4 ongeroteerde faktoren.

\section{Item}

Faktor 1

Fakior 2

Met een verpleegkundige kan ik praten over de

.34

$(.41)^{1)}$

dingen die mi] berighouden

Hoe mijn werblije in het zielenhuis zal zijn kan

ik zelf bernvloeden

Hoeveel tijd een verpleegkundige met mij praat

bepalt deze verpleegkundige zelf

Ik kan er zelf voor zorgen dat ik sneller herstel

Ik kan zelf meebepalen hoe ik word verzorgd

Waar ik met een verpleegkundige over praat kan ik zelf witmaken

Dokters bepalen hoe mijn ziekte verloopt

Ik kan met een verpleegkundige praten wanneer ik dat wil

.42

Verpleegkundigen maken uit welke verzorging ik krijg

Wanneer ik een gesprek heb met een arts, bepaalt

de ants waarover wij praten

Wat goed is voor mijn gezondheid bepaal ik uiteindelijk zelf

Met mijn mening wordt in het ziekenhuis rekening gehouden

Ik kan meebeslissen over de dag van mijn ontslag

uit het ritekenhuis

Wanneer ik bepalde informatie wil van een arts dan krijg ik die ook

le laktor

3.30

1.87

23.6

2 e faktor

1.15

13.4

3e faktor

.99

8.2

7.1

1) item is opgenomen in de somvariabele van de items die laden op de cerste faktor. 


\section{BINLAGE III}

Een faktorladingen natrix van een faktoranalyse over 13 items betreffende de verwerkingsstrategieên van patiënten indien 'het verblijf in thet ziekenhuis niet geheel natar wens verloopt'. Een principale komponenten analyse met Varimax-rotatie is uitgevoerd. Ladingen groter dan 50 worden gegeven. In het onderste deel wordt een owercicht gegeven van de eigenwaarden en de verklaarde variantie van de eerste 5 ongeroteerde faktoren. Het item "praten met partner/vriend" is varwege de imhoud van het item, niet in de subschal 'konfronterende strategieenn" opgenomen. Het item "praten met medepatiënten." laadi op geen wan de faktoren noemenswaardig.

\begin{tabular}{llll}
\hline Item & Faktor 1 & Faktor 2 & Faktor 3 \\
\hline
\end{tabular}

- Dan ga ik pratten met een arts

$(.47)$

- Dan probeer ik daar niet over te denken

.56

- Dan word ik humeurig

- Dan ga ik praten mel mijn partner of

een goede vriend of vriendin

- Dan praat ik mijzelf moed in

Dan leg ik mij er bij neer

.66

- Dan word ik kwaad

- Dan zet ik voor mijzelf alles op een rijtje

.67

- Dan zoek ik kontakt met andere patiënten

- Dan richt ik mij op andere dingen .70

- Dan ga ik praten met de verpleging .66

- Dan ga ik bij mijzelf na wat ik het beste kan doen

- Dan neem ik een afwachtende houding aan

61.

\begin{tabular}{lcc}
\hline Ongeroteerde faktor & Eigenwarde & Verklaarde variantie (\%) \\
le faktor & 2.39 & 18.4 \\
2e faktor & 2.14 & 16.5 \\
3e faktor & 1.51 & 11.6 \\
4e faktor & 1.02 & 7.9 \\
Se faktor & .96 & 7.4
\end{tabular}




\section{BIJLAGE IV}

Faktorladingen matrix na een principale komponenten analyse en Varimax-rotatie over 8 ittems betreftende "met wie wordt overllegd" en "wie neemt uiteindelijk de beslissing" over specifieke aspekten van de (orgamisatie van de) zorg. Ladingen groter dan 50 worden gegeven.

\begin{tabular}{|c|c|c|}
\hline Ittem & Faktor 1 & Faktor 2 \\
\hline Inschathelen van andere medische disciplines & .78 & \\
\hline Inschakelen van paramedische disciplines (b.v. logopedie) & .80 & \\
\hline $\begin{array}{l}\text { Toewijzen van patienten aan verpleegkundigen } \\
\text { (indien net van toepassing niet invullen) }\end{array}$ & & .79 \\
\hline -Of er formeel werkoverleg plaatsvindt & & .80 \\
\hline -Of en wanneer een patient ontslagen wordt & .78 & \\
\hline -Inschakelen van wijkverpleegkundige na ontslag & & .65 \\
\hline -Inschakelen van huisarts na ontslag & .77 & \\
\hline $\begin{array}{l}\text {-Inschakelen van ntet-medische disci- } \\
\text { plines (b.\%. maatschappelijk werk) }\end{array}$ & & .65 \\
\hline
\end{tabular}

Faktoranalyse over dichotome items. Een faktoranalyse wordt uitgevoerd op grond van een korrelatie matrix. Het betreft produkt-moment korrelaties tussen de items. Deze korrelaties zijn gevoelig voor scheve verdelingen. Dit blijkt met name bij dichotome items een probleem (zie bijwoorbeeld Nunnally, 1967, p. 130-133; Ten Berge, 1972). Aangetoond is dat een korrelatie tussen twee dichotome wariabelen alleen de maximale waarde $1 \mathrm{kan}$ aannemen indien deze variabelen een identieke verdeling hebben. Hoe meer hun verdeling van elkaar verschilt (gelet op hun p-waarden) hoe kJeiner hun korrelatie maximaal zal kunnen zijn. Deze maximale korrelatie wordt phi-max genoemd. Zolang de gevonden korrelaties ruim beneden hum phi-max waarden zijn gelegen, is faktoranalyse, voorzover het de scheefheid van verdelingen betreft, toelaatbaar. In de onderstaande tabel worden do produkt-moment korrelaties (links) en de phi-max waarden gegeven (rechts) voor de items wastran de p-waarden het meest uit elkaar liggen.

\begin{tabular}{lcccccc}
\hline & \multicolumn{3}{c}{ produkt-moment } & \multicolumn{4}{c}{$\begin{array}{c}\text { phi-max } \\
\text { item }\end{array}$} \\
& $1(.51)$ & $8(.50)$ & $5(.49)$ & 1 & 8 & 5 \\
\hline $7(.34)$ & .46 & .22 & .52 & .71 & .72 & .73 \\
$4(.30)$ & -.02 & .28 & -.09 & .64 & .65 & .67 \\
$3(.22)$ & .00 & .28 & -.08 & .52 & .53 & .54 \\
\hline
\end{tabular}

* Tussen haskjes wordt de p-waarde van een item gegeven. 


\section{BIJLAGE V}

Faktorladingen matrix van een faktoramalyse over 11 items betreffende de invloed van diverse kategorieèn personen op de zorgveriening. Principale komponenten analyse met Varimax-rotatie. Ladingen groter dan .40 worden gegeven. De eigenwaarden wan de eerste drie ongeroteerde faktoren bedragen: 4.60, 3.01. 99. Er zijn per respondent, per item, 5 obserwaties, waardoor er maximaal 2175 observaties zijn. Range van de items: minimale score $1=$ 'geen invloed" maximale score $5=$ 'erg veel invloed'.

$\overline{\text { Item }}$

Faktor 1

Faktor 2

-Planning van onderzoek en behandeling .76

-Welke werkmethoden op de afdeling worden gebruikt .91

-Manier waarop patiènten benaderd worden die problemen hebben .60

-Welke informatie aan familieleden en vrienden wordt gegewen .60

-Informatie die een arts aan de verpleegkundigen verstrekt over de patient

-Welke punten tijdens werkoverleg besproken worden

-Beoordelingsprocedure voor verpleegkundige

-Inschakelen van andere medische disciplines

-Toewijzen van patienten aan werpleegkundigen

-Of en wanneer een patient ontslagen wordt. 


\section{BIJLAGE VI}

Faktorladingen matrix van een faktoranalyse over 22 items betreffende kondities voor het aangaan van interakties. Principale komponenten analyse met warimax rotatie. Ladingen groter dan 30 worden gegeven. De certste geroleerde faktor kan worden benoernd als "sociale norm' en de tweede taktor als "wargenomen gelijkheid". Alleen item 17 en 21 zouden met deze interpretatie op de andere faktor moeten laden. Uit een betrowwbaarheidsanalyse blijkt item 21 de interne konsistentie wan de verzamoling items die laadt op de le faktor te verhogen. Voor item 17 geld dit niet. Dit hem is niet bij de konstructie wan de somvariablen betrokken.

Item

Faktor 1

Faktor 2

1. Wanneer kollega"s mijn manier van omgaan mel patienten zouden mocten beoordelen, denk ik dal ik er niet zo goed af kom*

2. Discussieren over het verpleegknndig werk wordt op de afdeling ower het algemeen niet zinvol gevonden*

3. Wanneer ik tijdens een bespreking iets zeg, wordt dat door anderen begrepen

4. Op de afdeling kan vrijuit gesproken wordlen over de gang var zaken

5. Mijn kollega's beoordelen mijn werk meestal positief

6. Andere verpleegkundigen op de afteling kijken op dezelfde wijze aan tegen de samenwerking met artsen als ik

7. Op de afdeling wordt het gewaardecrd wanneer je je gevoelens uit

8. De meeste verpleegkundigen van de afdeling denken anders ower hot verpleeglundig werk

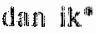

9. Gesprekken met kollega"s over hoe ik met pa-

110. Op de afdeling vindt men dat praten met een

lechnische worg $^{\text {t* }}$

11. De manier walarop ik mijn kollega's informeer over een patient wordt door hen miet altijd gewaardoerd * 
(vervalg bijlage $M T)$

12. Wamneer een verpleegkundige op de afdeling moeilijkheden heeft in het werk, dan wordt dat door de anderen altijd goed begrepen

13. Bij het nemen van beslissingen op de afdeling wordt met de mening van elke verpleegkundige evenveel rekening gehouden

14. Men windt het op de afdeling niet gewenst gevoelens van een patiënt in cen rapport op te. nemen ${ }^{*}$

15. I $\mathrm{k}$ ga op een andere manier met artsen om dan de meeste andere verpleegkundigen van de afdeling*

16. Op de afdeling bestaat onder verpleegkundigen owereenstemming over hoe je patienten moet begeleiden

17. Op de afdeling vindt men dat er over het algemeen te veel overlegd wordt*

18. Wat ik moeilijk vind in de begeleiding van patienten, wordt door andere verpleegkundigen op de afdeling ook moeilijk bevonden

19. Ik denk dat mijn kollega's mijn werk niet erg

20. Ik denk dat mijn kollega's graag met mij samenwierken

21. Over het moment waarop de behandeling mogelijkerwijs niet meer in het belang is van de patient wordt door verpleegkundigen op de afideling heel verschillend gedachı*

22. Op de afdeling wordt het gewrardeerd als je je standpunt weet te kerdedigen.

\footnotetext{
III Cespiegelde items.
} 


\section{BIILAGE VII}

Een Caktoranalyse over 10 items betreffende de reakties van verpleegkundigen wanneer zij moeilijkheden in hei werk erwaren (copingstrategieen). Faktorladingen matrix na faktoranalyse (principale komponenten analyse) met Varinax-rotatie. Ladingen groter dan .35 worden gegeven. De eigenwaarden wan de eerste vijf ongeroteerde faktoren zijn respektiewelijk $2.26,1.93,1.25,1.03$, .77 .

Item Faktor 1

Faktor 2

- Dan zoek ik kontact met een kollega om er over te praten

- Dan probeer ik er niet ower te denken .40

- Dan probeer ik mij af te reageren .68

- Dan zet ik voor mijzelf alles op een rijtje

- Dan richt ik mij op andere dingen .51

- Dan raak ik snel geïrriteerd. .79

- Dan breng ik dit in tijdens een bespreking

- Dan word ik humeurig .76

- Dan ga ik bij mijzelf na wat ik het beste kan doen

- Dan neem ik een afwachtende houding aan 


\section{BIJLAGE VIII}

Faktoranalyse over 11 tems betreffende de door verpleegkundigen gehanteerde beînwloedingsstrategieen ten opzichte van artsen en de verpleegkundige leiding naar de mening van verpleegkundigen, de verpleegkundige leiding en artsen (principale komponenten analyse met Varimax-rotatie). Eigenwaarden van de le drie ongeroteerde faktoren bedragen respektievelijk $3.83,1.85$ en 92 . Ladingen $>.50$ worden gegeven.

\begin{tabular}{|c|c|c|}
\hline$\overline{\text { Ttem }}$ & Fuktor 1 & Faktor 2 \\
\hline - Het watrom uiteenzetten & & .76 \\
\hline - In overleg treden & & .80 \\
\hline - Rekening houden met opvattingen van de ander & & .55 \\
\hline - Beroep doen op zijn/haar reputatie als deskundige & & $(45)$ \\
\hline - Terloops verwijzen naar regels/afspraken & & .60 \\
\hline - Beroepen op bestaande regels/afspraken & &.$\$ 5$ \\
\hline - Laten merken dat $u$ een weigering vervellend vindt & .57 & \\
\hline - Voor voldongen feit plaatsen & .72 & \\
\hline - Aandringen tot ander toegeeft & .76 & \\
\hline - Schermen met tegenmaatregelen & .81 & \\
\hline - Dreigen het hogerop te zoeken & .80 & \\
\hline
\end{tabular}




\section{CURRICULUM VITAE}

Eric Molleman werd geboren op 5 mei 1956 te Zieuwent, gemeente Lichtenvoorde. In 1974 behaalde hij aan het 'Marianum' te Groenlo het diploma Atheneum-B. In dat zelfde jaar begon hij met de studie Psychologie aan de Rijksunversiteit Groningen. Tijdens deze studie heeft de nadruk gelegen op de theoretische sociale psychologie en op de onderzoeksmethodologie. Na enkele jaren student-assistent te zijn geweest in de onderzoeksmethodologie, werd hem in de loop van het jaar 1979 de gegelegenheid geboden in het kader van zijn studie een onderzoek te verrichten binnen een door het Koningin Wilhelmina Fonds gesubsidieerd projekt. In 1981 behaalde hij het doctoraal diploma in de psychologie. Inmiddels had hij een betrekking gekregen bij het Academisch Ziekenhuis Groningen. Eerst werd hij ingezet op kleinschalige onderzoeken binnen de verpleegdienst van het Academisch ziekenhuis. Vanaf 1983 werd hij bij meer ornvangrijke onderzoeksprojekten betrokken, zoals het onderzoek dat in dit proefschrift wordt beschreven, onderzoek naar de relatie tussen het opleidingsnivo van verpleegkundigen en hun inzetbaarheid, onderzoek naar de sociaal-psychologische gevolgen van kanker in het hoofd-halsgebied en arbeidsmarktonderzoek. Sinds 1988 is hij werkzaam bij het Buro Opleiding, Onderzoek \& Ontwikkeling van het Academisch Ziekenhuis Groningen en is hij ondermeer als docent onderzoeksmethodologie betrokken bij de Posthogere Opleiding Verplegingswetenschap. 